\title{
Geochronology and Correlation of Tertiary Volcanic and Intrusive Rocks in Part of the Southern Toquima Range, Nye County, Nevada
}

Scientific Investigations Report 2013-5206 



\section{Geochronology and Correlation of Tertiary Volcanic and Intrusive Rocks in Part of the Southern Toquima Range, Nye County, Nevada}

By Daniel R. Shawe, Lawrence W. Snee, Frank M. Byers, Jr., and Edward A. du Bray

Scientific Investigations Report 2013-5206 


\title{
U.S. Department of the Interior SALLY JEWELL, Secretary
}

\section{U.S. Geological Survey Suzette M. Kimball, Acting Director}

\author{
U.S. Geological Survey, Reston, Virginia: 2014
}

For more information on the USGS - the Federal source for science about the Earth, its natural and living resources, natural hazards, and the environment, visit http://www.usgs.gov or call 1-888-ASK-USGS.

For an overview of USGS information products, including maps, imagery, and publications, visit http://www.usgs.gov/pubprod

To order this and other USGS information products, visit http://store.usgs.gov

Any use of trade, firm, or product names is for descriptive purposes only and does not imply endorsement by the U.S. Government.

Although this information product, for the most part, is in the public domain, it also may contain copyrighted materials as noted in the text. Permission to reproduce copyrighted items must be secured from the copyright owner.

Suggested citation:

Shawe, D.R., Snee, L.W., Byers, F.M., Jr., and du Bray, E.A., 2014, Geochronology and correlation of Tertiary volcanic and intrusive rocks in part of the southern Toquima Range, Nye County, Nevada: U.S. Geological Survey Scientific Investigations Report 2013-5206, 105 p., 1 plate, http://dx.doi.org/10.3133/sir20135206.

ISSN 2328-0328 (online) 


\section{Contents}

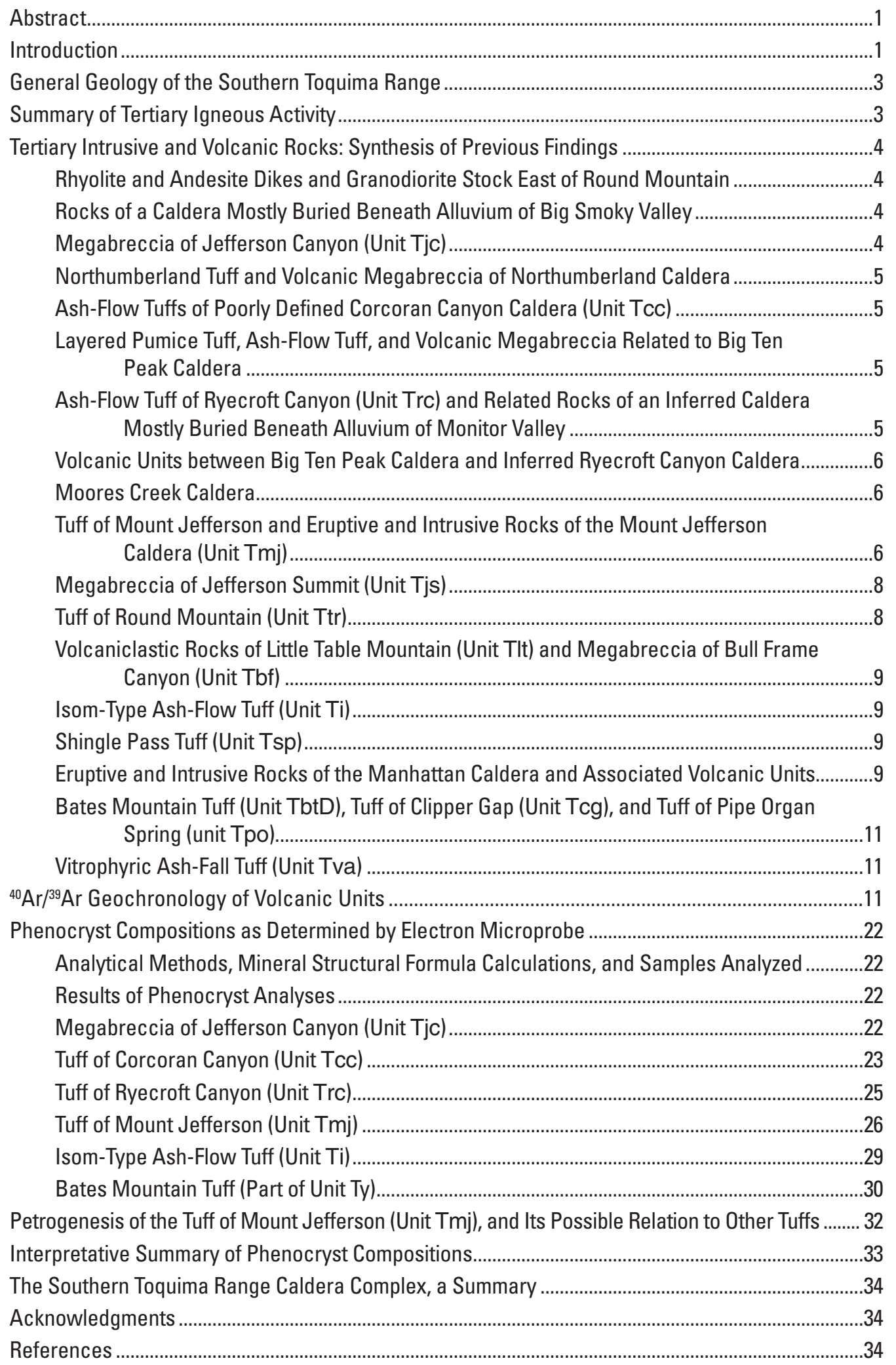


Appendix 1. ${ }^{40} \mathrm{Ar} /{ }^{39} \mathrm{Ar}$ Data for Mineral Separates from Tertiary Igneous Rocks, Southern Toquima Range, Nye County, Nevada (p. 39). Link

Appendix 2. Compositions (in Weight Percent) of Biotite in Samples of Tertiary Igneous Rocks in the Southern Toquima Range, Nye County, Nevada (p. 61) ............................ Link

Appendix 3. Recomputed Compositions (in Weight Percent) of Biotite in Samples of Tertiary Igneous Rocks in the Southern Toquima Range, Nye County, Nevada (p. 69) ..................... Link

Appendix 4 Structural Formulas (in Atoms) of Biotite in Samples of Tertiary Igneous Rocks in the Southern Toquima Range, Nye County, Nevada (p. 77) ............................. Link

Appendix 5. Compositions (in Weight Percent) of Amphiboles in Samples of Tertiary Igneous Rocks in the Southern Toquima Range, Nye County, Nevada (p. 85)...

Appendix 6. Structural Formulas (in Atoms) and Amphibole Species of Amphiboles in Samples of Tertiary Igneous Rocks in the Southern Toquima Range, Nye County, Nevada (p. 89)

Appendix 7. Compositions (in Weight Percent) and End-Member Proportions for Pyroxene in Samples of Tertiary Igneous Rocks in the Southern Toquima Range, Nye County, Nevada (p. 93).

Appendix 8. Compositions (in Weight Percent) and End-Member Proportions of Plagioclase and Sanidine in Samples of Tertiary Igneous Rocks in the Southern Toquima Range, Nye County, Nevada (p. 97)

\section{Plate}

1. Geologic Map of the Southern Toquima Range, Nye County, Nevada, Showing Tertiary Volcanic and Intrusive Rock Units Studied, Locations of ${ }^{40} \mathrm{Ar} /{ }^{39} \mathrm{Ar}$ Dating Samples, and Locations of Samples That Contain Chemically Analyzed Phenocrysts.

\section{Figures}

1. Map of the southern Toquima Range, Nevada, showing calderas discussed in this report.

2. Diagrams of ${ }^{40} \mathrm{Ar} /{ }^{39} \mathrm{Ar}$ age spectra of minerals in volcanic rocks of the southern Toquima Range, Nye County, Nevada 13

3. Ternary diagram of $\mathrm{Mg}-\mathrm{Al}^{3+}+\mathrm{Fe}^{3+}+\mathrm{Ti}-\mathrm{Fe}^{2+}+\mathrm{Mn}$ showing relative cation abundances in biotite of one sample, southern Toquima Range, Nye County, Nevada $\ldots 23$

4. Ternary diagram of $\mathrm{Ca}-10 \mathrm{Ti}-2 \mathrm{Mg} /\left(\mathrm{Mg}+\mathrm{Fe}^{2+}\right)$ showing relative cation abundances in hornblende of one sample, southern Toquima Range, Nye County, Nevada

5. Diagram showing relative cation abundances of $\mathrm{Si}$ and $\mathrm{Mg} /\left(\mathrm{Mg}+\mathrm{Fe}^{2+}\right)$ in hornblende of one sample, southern Toquima Range, Nye County, Nevada.

6. Ternary diagram showing proportions of wollastonite, enstatite, and ferrosilite in clinopyroxene of one sample, southern Toquima Range, Nye County, Nevada ..........24

7. Ternary diagram of $\mathrm{Mg}-\mathrm{Al}^{3+}+\mathrm{Fe}^{3+}+\mathrm{Ti}-\mathrm{Fe}^{2+}+\mathrm{Mn}$ showing relative cation abundances in biotite of two samples, southern Toquima Range, Nye County, Nevada.

8. Ternary diagram of $\mathrm{Mg}-\mathrm{Al}^{3+}+\mathrm{Fe}^{3+}+\mathrm{Ti}-\mathrm{Fe}^{2+}+\mathrm{Mn}$ showing relative cation abundances in biotite of three samples, southern Toquima Range, Nye County, Nevada. .25

9. Ternary diagram of $\mathrm{Ca}-10 \mathrm{Ti}-2 \mathrm{Mg} /\left(\mathrm{Mg}+\mathrm{Fe}^{2+}\right)$ showing relative cation abundances in hornblende of three samples, southern Toquima Range, Nye County, Nevada

10. Diagram showing relative cation abundances of $\mathrm{Si}$ and $\mathrm{Mg} /\left(\mathrm{Mg}+\mathrm{Fe}^{2+}\right)$ in hornblende of three samples, southern Toquima Range, Nye County, Nevada. 
11. Ternary diagram showing molecular end-member proportions of albite, anorthite, and orthoclase feldspars in two samples, southern Toquima Range, Nye County, Nevada.

12. Ternary diagram of $\mathrm{Mg}-\mathrm{Al}^{3+}+\mathrm{Fe}^{3+}+\mathrm{Ti}-\mathrm{Fe}^{2+}+\mathrm{Mn}$ showing relative cation abundances in biotite of three samples, southern Toquima Range, Nevada

13. Ternary diagram of $\mathrm{Mg}-\mathrm{Al}^{3+}+\mathrm{Fe}^{3+}+\mathrm{Ti}-\mathrm{Fe}^{2+}+\mathrm{Mn}$ showing relative cation abundances in biotite of three samples, southern Toquima Range, Nye County, Nevada...

14. Ternary diagram of $\mathrm{Mg}-\mathrm{Al}^{3+}+\mathrm{Fe}^{3+}+\mathrm{Ti}-\mathrm{Fe}^{2+}+\mathrm{Mn}$ showing relative cation abundances in biotite of two samples, southern Toquima Range, Nye County, Nevada.

15. Ternary diagram of $\mathrm{Ca}-10 \mathrm{Ti}-2 \mathrm{Mg} /\left(\mathrm{Mg}+\mathrm{Fe}^{2+}\right)$ showing relative cation abundances in hornblende of seven samples, southern Toquima Range, Nye County, Nevada .............28

16. Ternary diagram of $\mathrm{Ca}-10 \mathrm{Ti}-2 \mathrm{Mg} /\left(\mathrm{Mg}+\mathrm{Fe}^{2+}\right)$ showing relative cation abundances in hornblende of three samples, southern Toquima Range, Nye County, Nevada ..............28

17. Ternary diagram of $\mathrm{Ca}-10 \mathrm{Ti}-2 \mathrm{Mg} /\left(\mathrm{Mg}+\mathrm{Fe}^{2+}\right)$ showing relative cation abundances in hornblende of one sample, southern Toquima Range, Nevada

18. Diagram showing relative cation abundances of Si and $\mathrm{Mg} /\left(\mathrm{Mg}+\mathrm{Fe}^{2+}\right)$ in hornblende of seven samples, southern Toquima Range, Nye County, Nevada..

19. Ternary diagram showing proportions of wollastonite, enstatite, and ferrosilite clinopyroxene in six samples, southern Toquima Range, Nye County, Nevada .

20. Ternary diagram showing molecular end-member proportions of albite, anorthite, and orthoclase feldspars in two samples, southern Toquima Range, Nye County, Nevada.

21. Ternary diagram of $\mathrm{Ca}-10 \mathrm{TI}-2 \mathrm{Mg} /\left(\mathrm{Mg}+\mathrm{Fe}^{2+}\right)$ showing relative cation abundances in hornblende of two samples southern Toquima Range, Nye County, Nevada.....

22. Diagram showing relative cation abundances of $\mathrm{Si}$ and $\mathrm{Mg} /\left(\mathrm{Mg}+\mathrm{Fe}^{2+}\right)$ in hornblende of two samples, southern Toquima Range, Nye County, Nevada

23. Ternary diagram showing proportions of wollastonite, enstatite, and ferrosilite in pyroxenes in three samples, southern Toquima Range, Nye County, Nevada

24. Ternary diagram showing molecular end-member proportions of albite, anorthite, and orthoclase feldspars in two samples, southern Toquima Range, Nye County, Nevada

25. Ternary diagram of $\mathrm{Ca}-10 \mathrm{Ti}-2 \mathrm{Mg} /\left(\mathrm{Mg}+\mathrm{Fe}^{2+}\right)$ showing relative cation abundances in hornblende of two samples, southern Toquima Range, Nye County, Nevada

26. Diagram showing relative cation abundances of $\mathrm{Si}$ and $\mathrm{Mg} /\left(\mathrm{Mg}+\mathrm{Fe}^{2+}\right)$ in hornblende of two samples, southern Toquima Range, Nye County, Nevada

27. Ternary diagram showing molecular end-member proportions of albite, anorthite, and orthoclase in feldspars in two samples, southern Toquima Range, Nye County, Nevada

\section{Table}

1. Summary of ${ }^{40} \mathrm{Ar} /{ }^{39} \mathrm{Ar}$ dates for Toquima Range, Nevada, mineral separates . .12

\section{Abbreviations Used in This Report}

$\begin{array}{ll}\mathrm{km} & \text { kilometer } \\ \mathrm{m} & \text { meter } \\ \mathrm{Ma} & \text { million years ago } \\ \mathrm{PI} & \text { phenocryst index }\end{array}$





\title{
Geochronology and Correlation of Tertiary Volcanic and Intrusive Rocks in Part of the Southern Toquima Range, Nye County, Nevada
}

\author{
By Daniel R. Shawe, Lawrence W. Snee, Frank M. Byers, Jr., and Edward A. du Bray
}

\section{Abstract}

Extensive volcanic and intrusive igneous activity, partly localized along regional structural zones, characterized the southern Toquima Range, Nevada, in the late Eocene, Oligocene, and Miocene. The general chronology of igneous activity has been defined previously. This major episode of Tertiary magmatism began with emplacement of a variety of intrusive rocks, followed by formation of nine major calderas and associated with voluminous extrusive and additional intrusive activity. Emplacement of volcanic eruptive and collapse megabreccias accompanied formation of some calderas. Penecontemporaneous volcanism in central Nevada resulted in deposition of distally derived outflow facies ashflow tuff units that are interleaved in the Toquima Range with proximally derived ash-flow tuffs.

Eruption of the Northumberland Tuff in the north part of the southern Toquima Range and collapse of the Northumberland caldera occurred about 32.3 million years ago. The poorly defined Corcoran Canyon caldera farther to the southeast formed following eruption of the tuff of Corcoran Canyon about 27.2 million years ago. The Big Ten Peak caldera in the south part of the southern Toquima Range Tertiary volcanic complex formed about 27 million years ago during eruption of the tuff of Big Ten Peak and associated air-fall tuffs. The inferred Ryecroft Canyon caldera formed in the south end of the Monitor Valley adjacent to the southern Toquima Range and just north of the Big Ten Peak caldera in response to eruption of the tuff of Ryecroft Canyon about 27 million years ago, and the Moores Creek caldera just south of the Northumberland caldera developed at about the same time. Eruption of the tuff of Mount Jefferson about 26.8 million years ago was accompanied by collapse of the Mount Jefferson caldera in the central part of the southern Toquima Range. An inferred caldera, mostly buried beneath alluvium of Big Smoky Valley southwest of the Mount Jefferson caldera, formed about 26.5 million years ago with eruption of the tuff of Round Mountain. The Manhattan caldera south of the Mount Jefferson caldera and northwest of the Big Ten Peak caldera formed in association with eruption of a series of tuffs, principally the Round Rock Formation, mostly ash-flow tuff, about 24.4 million years ago.
Extensive ${ }^{40} \mathrm{Ar} /{ }^{39} \mathrm{Ar}$ dating of about 60 samples that represent many of the Tertiary extrusive and intrusive rocks in the southern Toquima Range provides precise ages that refine the chronology of previously dated units. New geochronologic data indicate that the petrogenetically related Corcoran Canyon, Ryecroft Canyon, and Mount Jefferson calderas formed during a period of about 560,000 years.

Electron microprobe analyses of phenocrysts from 20 samples of six dated units underscore inferred petrogenetic relations among some of these units. In particular, compositions of augite, hornblende, and biotite in tuffs erupted from the Corcoran Canyon, Ryecroft Canyon, and Mount Jefferson calderas are similar, which suggests that magmas represented by these tuffs have similar petrogenetic histories. The unique occurrence of hypersthene in Isom-type tuff confirms its derivation from a source beyond the southern Toquima Range.

\section{Introduction}

Rocks in the southern Toquima Range in south-central Nevada define a major episode of Tertiary magmatism that culminated in late Oligocene time with formation of several calderas and associated major ash-flow tuff eruptions (fig. 1). Caldera formation was preceded by emplacement of a variety of intrusive rocks and involved additional intrusive and voluminous extrusive activity. Formation of volcanic eruptive and collapse megabreccias accompanied the evolution of some calderas. Penecontemporaneous volcanism elsewhere in the region also resulted in deposition of outflow facies ash-flow tuff units in the Toquima Range.

Our interest is focused on a block of six 1:24,000-scale quadrangles (fig. 1) mapped between 1967 and 1993, mostly by the senior author (see Shawe, 1995, 1998, 1999a, b, 2001, 2003a; Shawe and Byers, 1999; Shawe, Hardyman, and Byers, 2000). A recompiled 1:48,000-scale geologic map of the six quadrangles provides a synoptic view of the Tertiary igneous rocks (Shawe, 2002) in this area. The purpose of the present report is to clarify chronology and correlations of the numerous volcanic and intrusive units exposed in the area and to interpret the petrogenesis of a few of the volcanic units. 


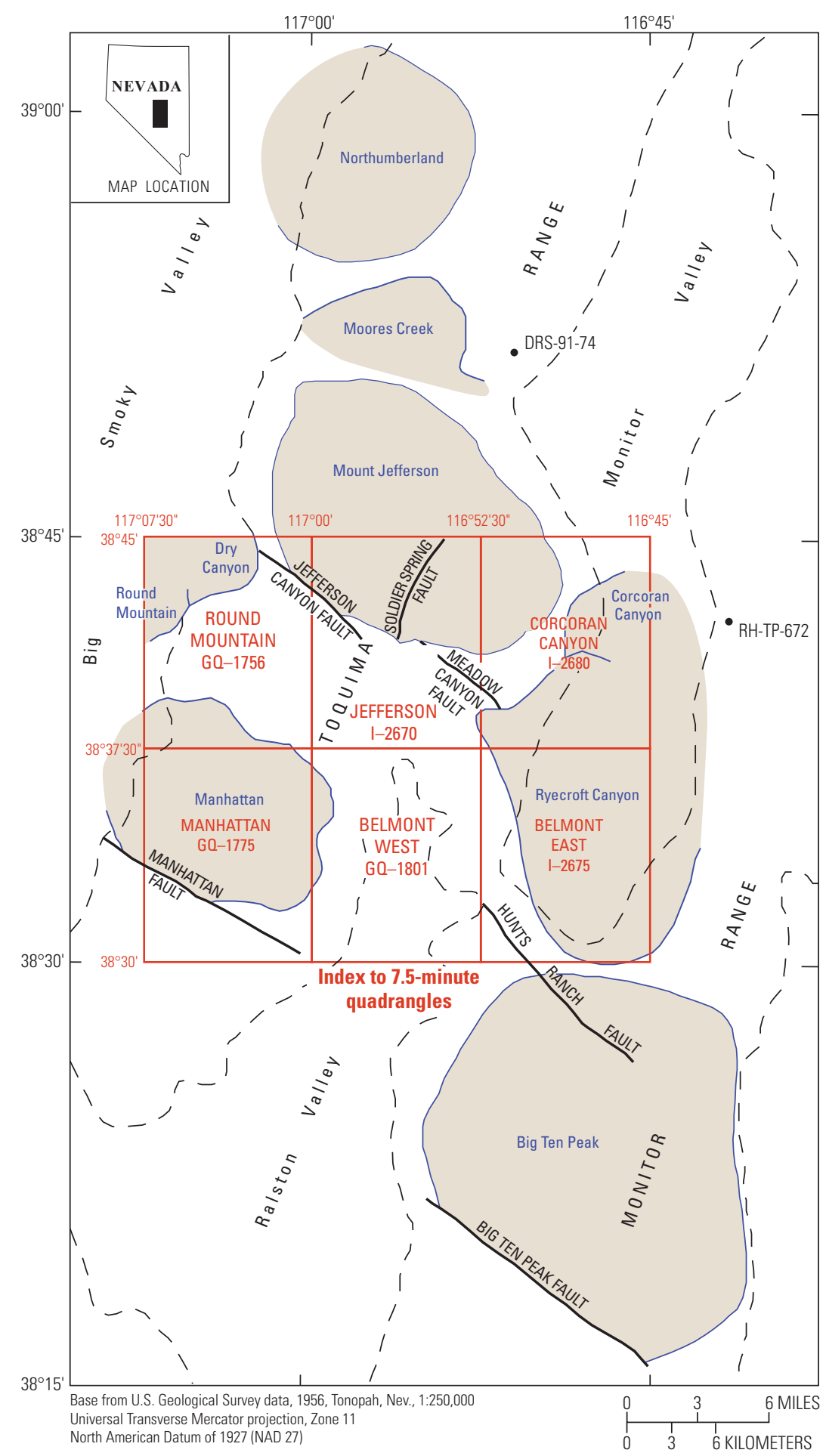

Figure 1. Southern Toquima Range, Nevada, showing calderas discussed in this report, area of plate 1, and locations of samples discussed in report that fall outside plate 1. Tan shading, calderas. 
Geologic mapping in the area by Shawe and associates produced a general framework for the Tertiary igneous activity of the southern Toquima Range. A generalized geologic map of this area (plate 1) portrays the distribution of the intrusive and volcanic units that are the subject of this study. Several earlier studies, including K-Ar age dating (Silberman and others, 1975) of many of the intrusive and volcanic units, resulted in a chronology of events that define basic volcanic stratigraphic relations and helped define several calderas. Petrographic studies (modal analyses) (Shawe, 1995; 1998; 1999a, b; Shawe and Byers, 1999; Shawe, Hardyman, and Byers, 2000) were also important in defining volcanic unit correlations. Microprobe analyses of volcanic rock phenocrysts, reported here, also facilitate stratigraphic correlations. Recent ${ }^{40} \mathrm{Ar} /{ }^{39} \mathrm{Ar}$ geochronology investigations presented here further refine stratigraphic relations and confirm correlation of several units, either with units elsewhere in the southern Toquima Range or with units derived from distant sources. Studies of the Tertiary igneous rocks in the area by others (as referenced in later sections) have provided critical additional information used to establish the Tertiary igneous history of the area.

Data presented in this report are used to refine earlier interpretations concerning the identity and ages of some units and to confirm the identity of some units derived from sources beyond the southern Toquima Range. All volcanic rock composition names are in accord with the International Union of Geological Sciences' chemical classification nomenclature (Le Bas and others, 1986).

\section{General Geology of the Southern Toquima Range}

The oldest rocks exposed in the southern Toquima Range are of Paleozoic age, chiefly marine sedimentary rocks. Cambrian and Ordovician rocks deposited in the ocean west and outboard of the North American craton were thrust into the study area during several episodes of tectonism that began in the late Paleozoic and continued until the Late Cretaceous. During tectonism, individual thrust plates were strongly folded and internally deformed. In the Late Cretaceous, as thrust faulting waned, three granite plutons were emplaced into the Paleozoic rocks. Intrusion was accompanied by metamorphism of adjacent Paleozoic rocks; subsequently the plutons were domed by additional intrusive activity, metamorphosed, and mineralized locally.

Igneous activity during the Tertiary included formation of several calderas, eruption of large volumes of ash-flow tuff, and emplacement of associated intrusive bodies and volcanic megabreccia throughout large parts of the southern Toquima Range (fig. 1). Mineralizing episodes, some commercially important, are related to igneous events described elsewhere
(Shawe, 1988, 2003b; Shawe, Marvin, and others, 1986; Shawe, Naeser, and others, 1987; and Shawe, Kucks, and Hildenbrand, 2004).

Several studies in parts of the southern Toquima Range beyond the area considered herein are pertinent to understanding the Tertiary igneous activity within our study area and are frequently referenced in the following text.

\section{Summary of Tertiary Igneous Activity}

Tertiary magmatism began about 36-35 million years ago (Ma) (Shawe, Marvin, and others, 1986) when a swarm of rhyolite dikes, a granodiorite stock (granodiorite of Dry Canyon; Shawe, 1995) and, a few kilometers east of Round Mountain, several andesite dikes were intruded into one of the Cretaceous granite plutons. About $33 \mathrm{Ma}$, a caldera (now mostly covered by alluvium in Big Smoky Valley just west of the Toquima Range) formed during ash-flow tuff eruption (Henry, 1997). About the same time, eruption of the Northumberland Tuff from a source about 25 kilometers $(\mathrm{km})$ to the north formed the Northumberland caldera (McKee, 1974). As summarized by Henry (1997), volcanic activity culminated in the southern Toquima Range between about 27.2 and $24.4 \mathrm{Ma}$, with formation of successive calderas that erupted the tuff of Corcoran Canyon (Boden, 1986) from the poorly defined Corcoran Canyon caldera (Shawe, Hardyman, and Byers, 2000; Shawe, Kucks, and Hildenbrand, 2004), the tuff of Big Ten Peak (Keith, 1993) from the Big Ten Peak caldera southeast of our map area, the tuff of Ryecroft Canyon (Boden, 1986) from a proposed caldera mostly covered by alluvium in Monitor Valley (Shawe and Byers, 1999), the tuff of Moores Creek (McKee, 1974) from the Moores Creek caldera north of our map area, the tuff of Mount Jefferson (Boden, 1986) from the Mount Jefferson caldera, the tuff of Round Mountain (Boden, 1986; Shawe, 1995; Henry, 1997) from a caldera mostly covered by alluvium in Big Smoky Valley, and the Round Rock Formation (Shawe, 1999a) from the Manhattan caldera. Several intrusive bodies, commonly localized near or along caldera margins, were emplaced during the same period. The ash-flow tuffs erupted from these calderas are calc-alkalic trachydacites to rhyolites. Eruptive megabreccias, localized along structural margins, are a notable feature of several of the southern Toquima Range calderas (Shawe and Snyder, 1988). Several eruptive megabreccia deposits are associated with the Manhattan and Mount Jefferson calderas and are probably derived from other calderas in the area. Diagnostic characteristics of the megabreccia deposits include their occurrence as outflow facies deposits, large clasts of rock types not present at the surface, basal zones of welded ash (vitrophyre), and occasional clasts encased in volcanic glass, which are indicative of derivation from deeper, hotter levels within the source magma reservoir. 


\section{Tertiary Intrusive and Volcanic Rocks: Synthesis of Previous Findings}

Stratigraphic positions summarized in this section of previously described volcanic and intrusive rocks and those documented in the present study are shown in the correlation of map units on plate 1 .

\section{Rhyolite and Andesite Dikes and Granodiorite Stock East of Round Mountain}

Radiometric dates of rhyolite dikes (Tr) from a swarm that intrudes Cretaceous granite and its wall rocks east of Round Mountain include a K-Ar date on sanidine of $34.3 \pm 0.9 \mathrm{Ma}$ (Marvin and others, 1973) and K-Ar dates on impure sanidine of $34.4 \pm 1.2$, sanidine of $34.7 \pm 1.2 \mathrm{Ma}$, biotite of 36.0 $1.2 \mathrm{Ma}$, and biotite of $35.1 \pm 1.2 \mathrm{Ma}$ (Shawe, Marvin, and others, 1986). A fission-track date on zircon from a mineralized rhyolite dike is $36.3 \pm 1.7 \mathrm{Ma}$ (Shawe, Marvin, and others, 1986).

- $34.3 \pm 0.9 \mathrm{Ma}$ (K-Ar on sanidine; Marvin and others, 1973)

- $34.4 \pm 1.2 \mathrm{Ma}$ (K-Ar on impure sanidine; Shawe, Marvin, and others, 1986)

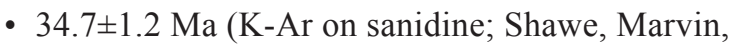
and others, 1986)

- 35.1 $1.2 \mathrm{Ma}$ (K-Ar on biotite; Shawe, Marvin, and others, 1986)

- 36.0 $\pm 1.2 \mathrm{Ma}$ (K-Ar on biotite; Shawe, Marvin, and others, 1986)

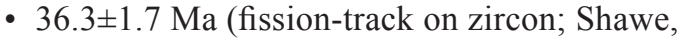
Marvin, and others, 1986)

The granodiorite stock of Dry Canyon (Tgd) (Shawe, 1981, 1995) intruded the rhyolite dike swarm and granite east of Round Mountain. Two fission-track dates on zircon from the granodiorite are $36.1 \pm 1.6 \mathrm{Ma}$ and $37.4 \pm 2.3 \mathrm{Ma}$. A fissiontrack date on sphene from the same rock is $36.2 \pm 2.0 \mathrm{Ma}$ (Shawe and others, 1986).

- 36.1 $\pm 1.6 \mathrm{Ma}$ (fission-track on zircon; Shawe and others, 1986)

- $36.2 \pm 2.0 \mathrm{Ma}$ (fission-track on sphene; Shawe and others, 1986).

- 37.4 $\pm 2.3 \mathrm{Ma}$ (fission-track on zircon; Shawe and others, 1986)

Andesite dikes (Ta) intrude the granodiorite stock and rhyolite dikes. A K-Ar date on biotite from a latite dike of the andesite set is $36.5 \pm 1.2 \mathrm{Ma}$ (Shawe, Marvin, and others, 1986).

- 36.5 $\pm 1.2 \mathrm{Ma}$ (K-Ar on biotite; Shawe, Marvin, and others, 1986)
None of the rhyolite, granodiorite, or andesite intrusions has been dated by the ${ }^{40} \mathrm{Ar} /{ }^{39} \mathrm{Ar}$ method. Given that sanidine usually provides more accurate $\mathrm{K}-\mathrm{Ar}$ ages than biotite and that the method is more accurate than fission track ages, radiometric data suggest that the biotite K-Ar and the fissiontrack ages presented in the previous discussion are slightly too old. However, because sanidine is known to not completely melt and release all of its contained ${ }^{40} \mathrm{Ar}$ in conventional K-Ar dating, anomalously young ages may result.

\section{Rocks of a Caldera Mostly Buried Beneath Alluvium of Big Smoky Valley}

Henry (1997) described a 32.18 [32.37] $\pm 0.13 \mathrm{Ma}$ $\left({ }^{40} \mathrm{Ar} /{ }^{39} \mathrm{Ar}\right.$ on sanidine) tuff; the bracketed age is explained later in this paragraph. This tuff erupted from a caldera, which he named the Dry Canyon caldera (fig. 1) that is mostly buried beneath alluvium of Big Smoky Valley near Round Mountain. (See discussion in following paragraph.) All ages reported for samples from the Toquima Range by Henry (1997) assumed a standard age of $27.84 \mathrm{Ma}$ for Fish Canyon Tuff sanidine. Consequently, these ages (and others cited herein that were also calculated assuming an age of 27.84 Ma for Fish Canyon Tuff sanidine) must be increased by $0.19 \mathrm{Ma}$ to facilitate direct comparison with new data described herein. Ages recalculated in this fashion are enclosed in square brackets [ ] herein.

- $32.18[32.37] \pm 0.13 \mathrm{Ma}\left({ }^{40} \mathrm{Ar} /{ }^{39} \mathrm{Ar}\right.$ on sanidine; Henry, 1997)

\section{Megabreccia of Jefferson Canyon (Unit Tjc)}

A megabreccia unit exposed in Jefferson Canyon (Tjc) at the southwest margin of the Mount Jefferson caldera was inferred by Shawe and Snyder (1988) and Shawe (1995, 1999b) to be a product of a 27-Ma caldera-forming eruption. However, the unit, designated as megabreccia of Dry Canyon by Boden (1986) and megabreccia of Jefferson Canyon by Shawe (1995), has a biotite K-Ar date of $32.3 \pm 0.7 \mathrm{Ma}$ (Boden, 1986). Henry (1997) related the unit to ash-flow tuff erupted from a caldera (Dry Canyon caldera) buried beneath alluvium of Big Smoky Valley (see previous discussion). The tuff unit yielded a sanidine ${ }^{40} \mathrm{Ar} /{ }^{39} \mathrm{Ar}$ date of $32.18[32.37] \pm 0.13 \mathrm{Ma}$ (Henry, 1997) and a sanidine ${ }^{40} \mathrm{Ar} /{ }^{39} \mathrm{Ar}$ date of $32.56[32.75] \pm 0.07 \mathrm{Ma}$ on vitrophyric material (DRS-92-1) from the megabreccia unit (Shawe, 1995). Shawe $(1995,1999 b)$ suggested that contamination of the matrix of the megabreccia unit by assimilated granitic material may have compromised the determined ages of the unit, or that the dated material in the unit consists of 32-Ma clasts contained in a younger megabreccia matrix related to the Mount Jefferson caldera. Phenocryst composition data for sample DRS-91-92 cited later in this report suggest that the megabreccia and the tuff of Mount Jefferson (Tmj) are unrelated, and the presence of a 32-Ma caldera buried beneath Big Smoky Valley alluvium seems plausible. 
- $32.18[32.37] \pm 0.13 \mathrm{Ma}\left({ }^{40} \mathrm{Ar} /{ }^{39} \mathrm{Ar}\right.$ on sanidine; Henry, 1997)

- $32.3 \pm 0.7 \mathrm{Ma}$ (K-Ar on biotite; Boden, 1986).

- $32.56[32.75] \pm 0.07 \mathrm{Ma}\left({ }^{40} \mathrm{Ar} /{ }^{39} \mathrm{Ar}\right.$ on vitrophyric sanidine; Shawe, 1999)

\section{Northumberland Tuff and Volcanic Megabreccia of Northumberland Caldera}

According to McKee (1974), collapse of the Northumberland caldera (fig. 1) and eruption of the composite ash-flow Northumberland Tuff occurred about $32.3 \pm 1 \mathrm{Ma}$ (K-Ar on sanidine). The caldera is about $32 \mathrm{~km}$ in diameter, about half of which is buried beneath alluvium of Big Smoky Valley to the west. Prior to major caldera collapse, a relatively thin ash-flow sheet was emplaced as far as about $25 \mathrm{~km}$ beyond the present caldera margin. Enormous "landslide" blocks and chaotic breccia of Paleozoic rocks are preserved along the northeast and south caldera margins. These materials, locally enclosed in an ash matrix, may consist of caldera collapse deposits or represent eruptive megabreccia. The Northumberland Tuff consists of two or more ash-flow cooling units, interlayered in places with thin water-laid sediments. The tuff is a crystal-rich calc-alkalic rhyolite; quartz and sanidine are the principal phenocrysts; biotite and plagioclase phenocrysts are rare but ubiquitous (McKee, 1974).

- $32.3 \pm 1$ Ma (K-Ar on sanidine; McKee, 1974)

\section{Ash-Flow Tuffs of Poorly Defined Corcoran Canyon Caldera (Unit TCc)}

Evidence cited by Shawe, Hardyman, and Byers (2000) and Shawe, Kucks, and Hildenbrand (2004) indicates the presence of a poorly defined Corcoran Canyon caldera (fig. 1) from which the trachydacite tuff of Corcoran Canyon (TcC) (Boden, 1986) was erupted. Boden $(1986,1992)$ reported a sanidine K-Ar date of $27.7 \pm 0.7 \mathrm{Ma}$ and McKee and John (1987) reported a biotite K-Ar date of $27.1 \pm 0.7 \mathrm{Ma}$, both for samples from the upper part of the unit. Sanidine from another sample (DRS-91-82) of this unit yielded a ${ }^{40} \mathrm{Ar} /{ }^{39} \mathrm{Ar}$ date of $27.36 \pm 0.06 \mathrm{Ma}$. Locally, slabs of a lower member overlie an upper member of the tuff of Corcoran Canyon (TCC). Shawe, Hardyman, and Byers (2000) suggested that the juxtaposition resulted from collapse near the margin of the Mount Jefferson caldera. Alternatively, an earlier collapse may have occurred along an inferred margin of the Corcoran Canyon caldera.

- 27.1 $\pm 0.7 \mathrm{Ma}$ (K-Ar on biotite; McKee and John, 1987)

- $27.36 \pm 0.06 \mathrm{Ma}\left({ }^{40} \mathrm{Ar} /{ }^{39} \mathrm{Ar}\right.$ on sanidine, this report)

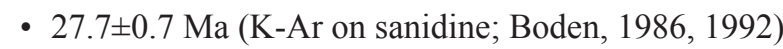

\section{Layered Pumice Tuff, Ash-Flow Tuff, and Volcanic Megabreccia Related to Big Ten Peak Caldera}

On the basis of an association between caldera rocks and dated rocks in the southeast corner of the map area (Shawe, Naeser, and others, 1987), Keith (1993) inferred a minimum age of about 27 Ma for formation of the Big Ten Peak caldera (fig. 1) southeast of our study area. Volcanic and intrusive units in that area (Shawe and Byers, 1999) include andesite plugs and flows (Tap); Shawe, Naeser, and others (1987) reported biotite K-Ar dates of $26.3 \pm 0.9 \mathrm{Ma}$ to $26.8 \pm 1.0 \mathrm{Ma}$ for unit Tap and a K-Ar date of 27.0 $\pm 1.0 \mathrm{Ma}$ for biotite in a white ash-fall tuff unit (Tat). A tuffaceous claystone-siltstonesandstone unit (Tcs) that underlies, and in part interfingers with, the white ash-fall tuff (Tat), a layered pumice tuff (Tpt), and a biotite-quartz latite ash-flow tuff (Tbql) that underlies the white ash-fall tuff unit, the claystone-siltstone-sandstone unit, and the layered pumice tuff, all appear to be continuous with the tuff of Big Ten Peak to the south (Keith, 1987). Volcanic megabreccia within and near the Big Ten caldera was interpreted by Keith (1993) to be of eruptive origin. A northwest-southeast-striking fault marks the southwest margin of the caldera, which locally also includes a zone of megabreccia.

- $26.3 \pm 0.9$ to $26.8 \pm 1.0 \mathrm{Ma}$ (K-Ar on biotite; Shawe, Naeser, and others, 1987)

- 27.0土1.0 Ma (K-Ar on biotite; Shawe, Naeser, and others, 1987)

\section{Ash-Flow Tuff of Ryecroft Canyon (Unit Trc) and Related Rocks of an Inferred Caldera Mostly Buried Beneath Alluvium of Monitor Valley}

Shawe and Byers (1999) proposed that the ash-flow tuff of Ryecroft Canyon (Trc) (Boden, 1986) was erupted from a caldera (fig. 1) mostly buried beneath alluvium in the south part of Monitor Valley. Thick sections of the Ryecroft Canyon, believed to be intracaldera fill, border the south part of Monitor Valley. Shawe and Byers (1999) and Shawe, Hardyman, and Byers (2000) described two types of rhyolite in the Ryecroft Canyon: typical (22-35 percent of phenocrysts are quartz), and quartz-rich (35-45 percent of phenocrysts are quartz). Shawe and Byers (1999) discerned no consistent spatial or stratigraphic distribution of the two rhyolite types. Boden $(1986,1992)$ reported a sanidine K-Ar date of 25.0 \pm 0.5 Ma for what he defined as the upper quartz-rich part of the tuff of Ryecroft Canyon, whereas we report ${ }^{40} \mathrm{Ar} /{ }^{39} \mathrm{Ar}$ dates of $27.05 \pm 0.06 \mathrm{Ma}$ (DRS-91-31) and 26.82 $\pm 0.04 \mathrm{Ma}$ (DRS-85-224) on sanidine and a sanidine ${ }^{40} \mathrm{Ar} /{ }^{39} \mathrm{Ar}$ isochron date (DRS-85-225) of 27.13 $\pm 0.03 \mathrm{Ma}$ for samples from the (undivided) Ryecroft Canyon. (Sample locations are shown on pl. 1 
unless otherwise noted.) Henry (1997) reported a sanidine ${ }^{40} \mathrm{Ar} /{ }^{39} \mathrm{Ar}$ date of $27.08[27.27] \pm 0.09 \mathrm{Ma}$ for the tuff of Ryecroft Canyon.

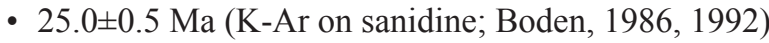

- $26.82 \pm 0.04 \mathrm{Ma}\left({ }^{40} \mathrm{Ar} /{ }^{39} \mathrm{Ar}\right.$ on sanidine; this report)

- $27.05 \pm 0.06 \mathrm{Ma}\left({ }^{40} \mathrm{Ar} /{ }^{39} \mathrm{Ar}\right.$ on sanidine; this report)

- $27.13 \pm 0.03 \mathrm{Ma}\left({ }^{40} \mathrm{Ar} /{ }^{39} \mathrm{Ar}\right.$ on sanidine; this report)

- 27.08 [27.27] $\pm 0.09 \mathrm{Ma}\left({ }^{40} \mathrm{Ar} /{ }^{39} \mathrm{Ar}\right.$ on sanidine; Henry, 1997)

A cluster of undated rhyolite flow domes (Tfd) at the south end of Monitor Valley (Shawe and Byers, 1999) form an arc coincident with the inferred south margin of the caldera from which the tuff of Ryecroft Canyon seemingly was erupted. These domes may represent a late magmatic event associated with evolution of the inferred caldera.

The megabreccia of Meadow Canyon (Tmc) and the tuff of Antone Canyon (Tac) are related to the tuff of Ryecroft Canyon (Trc) inasmuch as they interfinger with, and are petrologically similar to, the tuff of Ryecroft Canyon. They were emplaced probably late during development of the caldera from which the Ryecroft Canyon was erupted (Shawe, 1999b). The megabreccia of Hunts Canyon (Tmh) (Shawe and Byers, 1999), southwest of the inferred structural margin of the Ryecroft Canyon caldera, contains mostly clasts of the Ryecroft Canyon and likely represents outflow facies tuff erupted in the late stages of caldera development.

\section{Volcanic Units between Big Ten Peak Caldera and Inferred Ryecroft Canyon Caldera}

As suggested by their position between and marginal to both calderas, several volcanic units, including rhyolite flows and domes (Tfd) (see previous discussion), a rhyolitic lahar (Tlh) (flow breccia), a vitrophyric rhyolitic lava (Trv), megabreccia of Hunts Canyon (Tmh) (discussed previously), and a mesobreccia unit (Tms) (Shawe, 1998; Shawe and Byers, 1999), could be cogenetic. These units have not been radiometrically dated.

\section{Moores Creek Caldera}

A thick accumulation of apparently intracaldera highsilica rhyolite ash-flow tuff ( $27.3 \pm 0.5 \mathrm{Ma}$ on sanidine, $27.0 \pm 0.8 \mathrm{Ma}$ on biotite) is peripheral to the north margin of the Mount Jefferson caldera (Boden, 1986) and is locally adjacent to volcanic megabreccia. Boden (1986) reported a K-Ar date of 26.1 $\pm 1.1 \mathrm{Ma}$ for sanidine from a rhyolite plug that intruded the north margin of the Moores Creek caldera (fig. 1).

- 26.1 $\pm 1.1 \mathrm{Ma}$ (K-Ar on sanidine; Boden, 1986)

- 27.0 $0.8 \mathrm{Ma}$ (K-Ar on biotite; Boden, 1986)

- $27.3 \pm 0.5 \mathrm{Ma}$ (K-Ar on sanidine; Boden, 1986)

\section{Tuff of Mount Jefferson and Eruptive and Intrusive Rocks of the Mount Jefferson Caldera (Unit Tmj)}

The rocks of the Mount Jefferson caldera (fig. 1) were initially described in some detail by Boden $(1986,1992)$. He defined three members of the tuff of Mount Jefferson (Tmj), including a lower member (not within area of plate 1) that is exposed only north of the area of our mapped quadrangles, an upper member, and a capping member. He also designated an outflow member, the tuff of Round Mountain (Ttr), which is now thought to have been erupted from a caldera largely buried beneath alluvium of Big Smoky Valley (discussed in the next section). Boden $(1986,1992)$ reported sanidine K-Ar dates of $26.5 \pm 0.5 \mathrm{Ma}$ and $25.9 \pm 0.5 \mathrm{Ma}$, and a biotite $\mathrm{K}-\mathrm{Ar}$ date of $26.6 \pm 0.6 \mathrm{Ma}$ for his upper member. He reported a sanidine K-Ar date of $25.8 \pm 0.5 \mathrm{Ma}$ for his capping member. We describe Boden's upper member as the principal member of this formation (because his lower member is absent in our map area) and Boden's capping member (lowest unit thereof) as an upper member (Shawe, 1999b). Henry (1997) considered Boden's $(1986,1992)$ lower member of the tuff of Mount Jefferson to be associated with the Moores Creek caldera (Boden, 1986).

- $25.8 \pm 0.5 \mathrm{Ma}$ (K-Ar on sanidine; Boden, 1986, 1992)

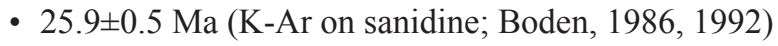

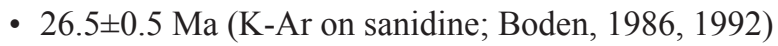

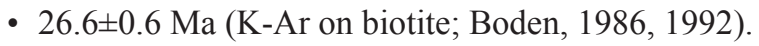

The principal member of the tuff of Mount Jefferson (Tmj) (Shawe, 1999b) is the volumetrically dominant part of the formation exposed in the map area. As previously described (Shawe, 1995, 1998, 1999a, b; Shawe and Byers, 1999; Shawe, Hardyman, and Byers, 2000), the unit consists chiefly of quartz latitic to rhyodacitic welded ash-flow tuff. The geochemistry of these rocks indicates that they are composed of rhyolite ( $\mathrm{SiO}_{2} 69.6-74.2$ percent). Analyzed vitrophyric units are trachydacite to dacite to rhyolitedacite in composition $\left(\mathrm{SiO}_{2} 67.1\right.$ percent, 68.2 percent, and 69.3 percent). Modal analyses of these rocks have allowed their classification using the phenocryst index (PI; the sum of quartz and alkali feldspar contents divided by the sum of plagioclase and mafic minerals, including biotite, hornblende, pyroxene, and opaque minerals) of Shawe (1999b) and Shawe, Hardyman, and Byers (2000). Five categories based on modal PI data for rocks of the tuff of Mount Jefferson are as follows:
1. Category 1 PI $=0.81-1.00$
2. Category 2 PI $=0.61-0.80$
3. Category 3 PI $=0.41-0.60$
4. Category 4 PI $=0.21-0.40$
5. Category 5 PI $=0.00-0.20$ 
The composition of phenocryst assemblages ranges from more evolved (PI 1) to less evolved (PI 5), although the chemistry of these rocks is uniformly moderately evolved.

Boden $(1986,1992)$ considered the southeast part of what we have included in the Mount Jefferson caldera (and the associated principal member of the tuff of Mount Jefferson) to form a separate, younger eruptive center designated as the Trail Canyon caldera. He apparently defined the caldera on the basis of the determined age of the tuff of Trail Canyon, namely sanidine K-Ar dates of $23.9 \pm 0.5 \mathrm{Ma}$ and 23.5 $\pm 0.4 \mathrm{Ma}$ (Boden's lower member) and 23.5 $\pm 0.4 \mathrm{Ma}$ (Boden's upper member). We believe Boden's tuff of Trail Canyon to be equivalent to tuff of Mount Jefferson, on the basis of field mapping in the 1980s and petrographic studies by R.F. Hardyman, then of the U.S. Geological Survey (written commun., 1985). To test that hypothesis, we determined numerous radiometric ages.

- $23.5 \pm 0.4 \mathrm{Ma}$ (K-Ar on sanidine; lower member; Boden, 1986, 1992)

- 23.5 $\pm 0.4 \mathrm{Ma}$ (K-Ar on sanidine; upper member; Boden, 1986, 1992)

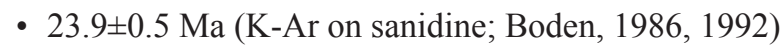

Samples collected west of the area of Boden's Trail Canyon caldera (west of the Soldier Spring fault - that is, the area mapped as tuff of Mount Jefferson, fig. 1), yielded sanidine ${ }^{40} \mathrm{Ar} /{ }^{39} \mathrm{Ar}$ dates of $26.78 \pm 0.05 \mathrm{Ma}$ (sample DRS-85-10), 26.78 $\pm 0.06 \mathrm{Ma}$ (DRS-85-78), and 26.86 $\pm 0.04 \mathrm{Ma}$ (DRS-85-48), and biotite ${ }^{40} \mathrm{Ar} /{ }^{39} \mathrm{Ar}$ dates of $26.79 \pm 0.04 \mathrm{Ma}$ (sample DRS-85-10), 26.85 $\pm 0.05 \mathrm{Ma}$ (DRS-85-78), 26.89 $\pm 0.05 \mathrm{Ma}$ (DRS-85-48).

- $26.78 \pm 0.05 \mathrm{Ma}\left({ }^{40} \mathrm{Ar} /{ }^{39} \mathrm{Ar}\right.$ on sanidine; this report $)$

- $26.78 \pm 0.06 \mathrm{Ma}\left({ }^{40} \mathrm{Ar} /{ }^{39} \mathrm{Ar}\right.$ on sanidine; this report)

- 26.86 $\pm 0.04 \mathrm{Ma}\left({ }^{40} \mathrm{Ar} /{ }^{39} \mathrm{Ar}\right.$ on sanidine; this report)

- $26.79 \pm 0.04 \mathrm{Ma}\left({ }^{40} \mathrm{Ar} /{ }^{39} \mathrm{Ar}\right.$ on biotite; this report)

- $26.85 \pm 0.05 \mathrm{Ma}\left({ }^{40} \mathrm{Ar} /{ }^{39} \mathrm{Ar}\right.$ on biotite; this report)

- $26.89 \pm 0.05 \mathrm{Ma}\left({ }^{40} \mathrm{Ar} /{ }^{39} \mathrm{Ar}\right.$ on (biotite; this report)

Samples collected within the area of Boden's Trail Canyon caldera (east of the Soldier Spring fault) yielded sanidine ${ }^{40} \mathrm{Ar} /{ }^{39} \mathrm{Ar}$ dates of $27.07 \pm 0.05 \mathrm{Ma}$ (sample DRS-91-98), 26.83 $\pm 0.05 \mathrm{Ma}$ (DRS-91-171), 27.00 $\pm 0.06 \mathrm{Ma}$ (RH-TP-571), 26.87 $\pm 0.04 \mathrm{Ma}$ (RH-TP-583), 26.85 $\pm 0.04 \mathrm{Ma}$ (RH-TP-590), 26.83 $\pm 0.07 \mathrm{Ma}$ (RH-TP-644), and $26.91 \pm 0.07 \mathrm{Ma}$ (RH-TP-646); biotite dates of $27.06 \pm 0.06 \mathrm{Ma}$ (sample DRS-91-98), 27.10 $\pm 0.04 \mathrm{Ma}$ (DRS-91-171), 27.02 $\pm 0.07 \mathrm{Ma}$ (RH-TP-571), 26.86 $\pm 0.05 \mathrm{Ma}$ (RH-TP-583), 26.99 $\pm 0.06 \mathrm{Ma}$ (RH-TP-590), 27.08 $\pm 0.04 \mathrm{Ma}$ (RH-TP-644), and $26.93 \pm 0.07 \mathrm{Ma}$ (RH-TP-646); and hornblende ages of 27.07 $\pm 0.05 \mathrm{Ma}$ (sample DRS-91-171), 26.69 $\pm 0.04 \mathrm{Ma}$ (RH-TP-583), and 26.78 $\pm 0.14 \mathrm{Ma}$ (RH-TP-644).
- $26.83 \pm 0.05 \mathrm{Ma}\left({ }^{40} \mathrm{Ar} /{ }^{39} \mathrm{Ar}\right.$ on sanidine; this report $)$

- $26.83 \pm 0.07 \mathrm{Ma}\left({ }^{40} \mathrm{Ar} /{ }^{39} \mathrm{Ar}\right.$ on sanidine; this report)

- $26.85 \pm 0.04 \mathrm{Ma}\left({ }^{40} \mathrm{Ar} /{ }^{39} \mathrm{Ar}\right.$ on sanidine; this report)

- $26.87 \pm 0.04 \mathrm{Ma}\left({ }^{40} \mathrm{Ar} /{ }^{39} \mathrm{Ar}\right.$ on sanidine; this report $)$

- $26.91 \pm 0.07 \mathrm{Ma}\left({ }^{40} \mathrm{Ar} /{ }^{39} \mathrm{Ar}\right.$ on sanidine; this report $)$

- $27.00 \pm 0.06 \mathrm{Ma}\left({ }^{40} \mathrm{Ar} /{ }^{39} \mathrm{Ar}\right.$ on sanidine; this report $)$

- $27.07 \pm 0.05 \mathrm{Ma}\left({ }^{40} \mathrm{Ar} /{ }^{39} \mathrm{Ar}\right.$ on sanidine; this report $)$

- 26.86 $\pm 0.05 \mathrm{Ma}\left({ }^{40} \mathrm{Ar} /{ }^{39} \mathrm{Ar}\right.$ on biotite; this report)

- $26.93 \pm 0.07 \mathrm{Ma}\left({ }^{40} \mathrm{Ar} /{ }^{39} \mathrm{Ar}\right.$ on biotite; this report $)$

- $26.99 \pm 0.06 \mathrm{Ma}\left({ }^{40} \mathrm{Ar} /{ }^{39} \mathrm{Ar}\right.$ on biotite; this report)

- $27.02 \pm 0.07 \mathrm{Ma}\left({ }^{40} \mathrm{Ar} /{ }^{39} \mathrm{Ar}\right.$ on biotite; this report $)$

- $27.06 \pm 0.06 \mathrm{Ma}\left({ }^{40} \mathrm{Ar} /{ }^{39} \mathrm{Ar}\right.$ on biotite; this report)

- $27.08 \pm 0.04 \mathrm{Ma}\left({ }^{40} \mathrm{Ar} /{ }^{39} \mathrm{Ar}\right.$ on biotite; this report)

- $27.10 \pm 0.04 \mathrm{Ma}\left({ }^{40} \mathrm{Ar} /{ }^{39} \mathrm{Ar}\right.$ on biotite; this report)

- $26.69 \pm 0.04 \mathrm{Ma}\left({ }^{40} \mathrm{Ar} /{ }^{39} \mathrm{Ar}\right.$ on hornblende; this report)

- $26.78 \pm 0.14 \mathrm{Ma}\left({ }^{40} \mathrm{Ar} /{ }^{39} \mathrm{Ar}\right.$ on hornblende; this report)

- $27.07 \pm 0.05 \mathrm{Ma}\left({ }^{40} \mathrm{Ar} /{ }^{39} \mathrm{Ar}\right.$ on hornblende; this report)

The age of ash-flow tuffs in the two areas are statistically indistinguishable, which substantiates their correlation. Petrographic data (Shawe, 1999b; Shawe, Hardyman, and Byers, 2000) and phenocryst composition data reported in a later section of this report also support correlation of these tuffs.

Several intrusive bodies were emplaced along the structural margin of the Mount Jefferson caldera or in northwest-striking structural zones near the caldera during, or closely following, its collapse and fill by ash-flow tuff, volcanic-eruptive megabreccia, and possibly volcanic-collapse megabreccias. A rhyolite plug (Trp) intrudes the megabreccia of Meadow Canyon (Tmc) along the Meadow Canyon fault (fig. 1), a northwest-striking structure just south of the south structural margin of the caldera. The Meadow Canyon fault is southeast of, and is en echelon to, the northwest-striking Jefferson Canyon fault (fig. 1), which marks the southwest margin of the Mount Jefferson caldera. Reported ages for the plug include a sanidine $\mathrm{K}-\mathrm{Ar}$ date of $26.4 \pm 0.3 \mathrm{Ma}$ (Boden, 1986, 1992), a biotite K-Ar date of 26.4 \pm 0.8 (McKee and John, 1987) and a sanidine ${ }^{40} \mathrm{Ar} /{ }^{39} \mathrm{Ar}$ date of 26.96 [27.15] \pm 0.06 (Henry, 1997).

- 26.4 \pm 0.3 Ma (K-Ar on sanidine; Boden, 1986, 1992)

- 26.4 \pm 0.8 (K-Ar on biotite; McKee and John, 1987)

- $26.96[27.15] \pm 0.06\left({ }^{40} \mathrm{Ar} /{ }^{39} \mathrm{Ar}\right.$ on sanidine; Henry, 1997)

About $1 \mathrm{~km}$ southeast of this plug and also intruded along the Meadow Canyon fault, two small plugs intruded the megabreccia of Meadow Canyon. These plugs are surrounded by a zone of heterolithic breccia (Thb) interpreted to have resulted from forceful intrusion of the plugs into the megabreccia (Shawe, 1999b; Shawe, Hardyman, and Byers, 
2000). Henry (1997) reported a sanidine ${ }^{40} \mathrm{Ar}{ }^{39} \mathrm{Ar}$ date of $27.14[27.33] \pm 0.06 \mathrm{Ma}$ for one of these plugs. A plug (Tooth Rock) that intruded the tuff of Mount Jefferson in the east part of the Mount Jefferson caldera, about $1 \mathrm{~km}$ inside the caldera structural margin, was dated by Boden $(1986,1992)$ as $21.7 \pm 0.4 \mathrm{Ma}$ on sanidine, by McKee and John (1987) as $26.2 \pm 0.8$ Ma by K-Ar on biotite, and by Henry (1997) as $26.65[26.84] \pm 0.06 \mathrm{Ma}$ by ${ }^{40} \mathrm{Ar} /{ }^{39} \mathrm{Ar}$ on biotite.

- $26.2 \pm 0.8 \mathrm{Ma}$ (K-Ar on biotite; McKee and John, 1987)

- $26.65[26.84] \pm 0.06 \mathrm{Ma}\left({ }^{40} \mathrm{Ar} /{ }^{39} \mathrm{Ar}\right.$ on biotite; Henry, 1997)

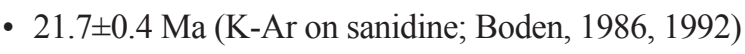

- $27.14[27.33] \pm 0.06 \mathrm{Ma}\left({ }^{40} \mathrm{Ar} /{ }^{39} \mathrm{Ar}\right.$ on sanidine; Henry, 1997)

A small hydrothermally altered and slightly mineralized plug (Trp) that appears to intrude the tuff of Mount Jefferson (Tmj) (sample DRS-91-58A) but is surrounded by Quaternary alluvium (Qs) and Miocene(?) megabreccia (Tcm) (Shawe, Hardyman, and Byers, 2000), about $0.5 \mathrm{~km}$ inside the east structural margin of the Mount Jefferson caldera, was dated by ${ }^{40} \mathrm{Ar} /{ }^{39} \mathrm{Ar}$ on potassium feldspar as $26.73 \pm 0.05 \mathrm{Ma}$.

- $\left(26.73 \pm 0.05 \mathrm{Ma} ;{ }^{40} \mathrm{Ar} /{ }^{39} \mathrm{Ar}\right.$ on potassium feldspar; Shawe, Hardyman, and Byers, 2000)

Several small plugs close to or along the structural margin of the Mount Jefferson caldera north of our study area were dated by Henry (1997) by ${ }^{40} \mathrm{Ar} /{ }^{39} \mathrm{Ar}$ on sanidine as $26.60[26.79] \pm 0.07 \mathrm{Ma}, 26.54[26.73] \pm 0.08 \mathrm{Ma}$, $26.60[26.79] \pm 0.08 \mathrm{Ma}, 26.93[27.12] \pm 0.09 \mathrm{Ma}, 26.93$ [27.12] $\pm 0.06 \mathrm{Ma}$, and 26.57 [26.76] $\pm 0.05 \mathrm{Ma}$.

- $26.54[26.73] \pm 0.08 \mathrm{Ma}\left({ }^{40} \mathrm{Ar} /{ }^{39} \mathrm{Ar}\right.$ on sanidine; Henry, 1997)

- $26.57[26.76] \pm 0.05 \mathrm{Ma}\left({ }^{40} \mathrm{Ar} /{ }^{39} \mathrm{Ar}\right.$ on sanidine; Henry, 1997)

- $26.60[26.79] \pm 0.07 \mathrm{Ma}\left({ }^{40} \mathrm{Ar} /{ }^{39} \mathrm{Ar}\right.$ on sanidine; Henry, 1997)

- $26.60[26.79] \pm 0.08 \mathrm{Ma}\left({ }^{40} \mathrm{Ar} /{ }^{39} \mathrm{Ar}\right.$ on sanidine; Henry, 1997)

- $26.93[27.12] \pm 0.06 \mathrm{Ma}\left({ }^{40} \mathrm{Ar} /{ }^{39} \mathrm{Ar}\right.$ on sanidine; Henry, 1997)

- $26.93[27.12] \pm 0.09 \mathrm{Ma}\left({ }^{40} \mathrm{Ar} /{ }^{39} \mathrm{Ar}\right.$ on sanidine; Henry, 1997)

\section{Megabreccia of Jefferson Summit (Unit Tjs)}

The megabreccia of Jefferson Summit (Tjs) (Shawe, 1999b) consists mostly of granitic material that fills three inferred pipes and a dike (the inferred emplacement conduits) and an inferred outflow sheet (with tuff matrix locally near base) lying conformably on the ash-flow tuff of Mount Jefferson (Tmj). Abundant cobble-size clasts of granite in the uppermost tuff of Mount Jefferson indicate that the megabreccia likely is transitional from the underlying tuff. The locally altered megabreccia is younger than at least part of the 26.8-26.7 Ma tuff of Mount Jefferson, and it probably is older than an alteration event that affected a nearby exposure of tuff of Mount Jefferson. Biotite from this tuff produced a K-Ar date of $25.7 \pm 0.6 \mathrm{Ma}$ (Shawe, 1999b); the date of the altered exposure is thought to reflect the date of alteration.

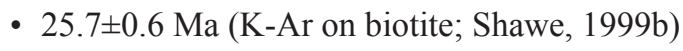

${ }^{40} \mathrm{Ar} /{ }^{39} \mathrm{Ar}$ dates for samples of three clasts (DRS-85-122, DRS-85-128, DRS-85-176; appendix 1) from the megabreccia of Jefferson Summit dike (Tjs on map plate this report; unit Tjsi of Shawe (1999b)), provide information about some dike components. A date on a white-mica-mineralized clast of quartzite of Cambrian Gold Hill Formation (80.2 $\pm 0.14 \mathrm{Ma}$; sample DRS-85-122) suggests that quartzite underlying or enclosed in the Round Mountain granite pluton was affected by postgranite emplacement metamorphism and mineralization (Shawe, 1995, 2003b) and became entrained in the Jefferson Summit megabreccia (Tjs) when the megabreccia was erupted. A clast of porphyritic granite (DRS-85-128) gave a date of approximately $80 \mathrm{Ma}$ and a clast of andesite (DRS-85-176) gave a ${ }^{40} \mathrm{Ar} /{ }^{39} \mathrm{Ar}$ date of $33.35 \pm 0.06 \mathrm{Ma}$. The andesite clast indicates the presence of a blind intrusion at depth because the nearest surface exposure of andesite is at least $6 \mathrm{~km}$ distant.

- $80.2 \pm 0.14 \mathrm{Ma}\left({ }^{40} \mathrm{Ar} /{ }^{39} \mathrm{Ar}\right.$ on white mica; Shawe (1999b)

- $80 \mathrm{Ma}$ (approximately); $\left({ }^{40} \mathrm{Ar} /{ }^{39} \mathrm{Ar}\right.$ on porphyritic granite; Shawe (1999b)

- 33.35 $\pm 0.06 \mathrm{Ma}$ (40Ar/39Ar on andesite; Shawe (1999b)

\section{Tuff of Round Mountain (Unit Ttr)}

Henry (1997) defined a caldera mostly covered by alluvium in Big Smoky Valley as the source of the tuff of Round Mountain (Ttr), and he dated intracaldera tuff of the caldera as $26.51[26.70] \pm 0.03 \mathrm{Ma}\left({ }^{40} \mathrm{Ar} /{ }^{39} \mathrm{Ar}\right.$ on sanidine). Boden $(1986,1992)$ previously reported dates for the tuff of Round Mountain (described by him as the Round Mountain member of the tuff of Mount Jefferson, which he considered to be outflow facies tuff) as $26.5 \pm 0.4 \mathrm{Ma}$, $26.8 \pm 0.8 \mathrm{Ma}, 27.3 \pm 1.1 \mathrm{Ma}$, and $26.8 \pm 0.5 \mathrm{Ma}$ (all K-Ar on sanidine), and $27.2 \pm 0.6 \mathrm{Ma}, 25.5 \pm 0.6 \mathrm{Ma}$, and $24.4 \pm 0.6 \mathrm{Ma}$ (all K-Ar on biotite). Shawe and others (1987) reported a sanidine K-Ar date of 27.0 $\pm 1.0 \mathrm{Ma}$, a biotite $\mathrm{K}-\mathrm{Ar}$ date of 26.7 $\pm 1.7 \mathrm{Ma}$, a zircon fission-track date of $26.0 \pm 2.6 \mathrm{Ma}$, and an apatite fission-track date of $28.4 \pm 7.8 \mathrm{Ma}$ for the tuff of Round Mountain.

- 24.4 $\pm 0.6 \mathrm{Ma}$ (K-Ar on biotite; Boden, 1986, 1992)

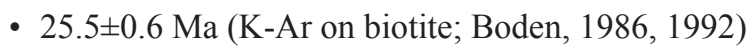

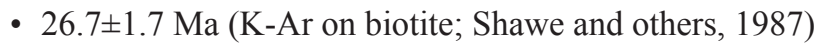

- $27.2 \pm 0.6 \mathrm{Ma}$ (K-Ar on biotite; Boden, 1986, 1992) 


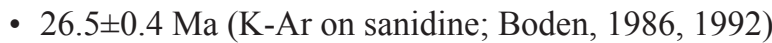

- $26.51[26.70] \pm 0.03 \mathrm{Ma}\left({ }^{40} \mathrm{Ar} /{ }^{39} \mathrm{Ar}\right.$ on sanidine; Henry, 1997)

- $26.8 \pm 0.5 \mathrm{Ma}\left({ }^{40} \mathrm{Ar}{ }^{\beta 9} \mathrm{Ar}\right.$ on sanidine; Boden, 1986,1992$)$

- $26.8 \pm 0.8 \mathrm{Ma}\left({ }^{40} \mathrm{Ar}{ }^{\beta 9} \mathrm{Ar}\right.$ on sanidine; Boden, 1986,1992$)$

- 27.0土1.0 Ma (K-Ar on sanidine; Shawe and others, 1987)

- $27.3 \pm 1.1 \mathrm{Ma}\left({ }^{40} \mathrm{Ar}{ }^{\beta 9} \mathrm{Ar}\right.$ on sanidine; Boden, 1986,1992$)$

- 26.0土2.6 Ma (zircon fission-track; Shawe and others, 1987)

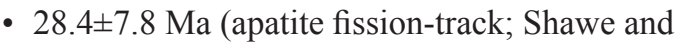
others, 1987)

\section{Volcaniclastic Rocks of Little Table Mountain (Unit Tlt) and Megabreccia of Bull Frame Canyon (Unit Tbf)}

The tuff of Mount Jefferson (Tmj) is overlain by a sequence of interlayered volcaniclastic rocks including tuffaceous clastic units, ash-flow tuff, and zeolitic tuff. Tuffaceous sandstone (TIt) (sample DRS-92-16) near the base of the volcaniclastic rocks is $26.65 \pm 0.07 \mathrm{Ma}\left({ }^{40} \mathrm{Ar} /{ }^{39} \mathrm{Ar}\right.$ on sanidine). The volcaniclastic rocks are petrographically similar to, and therefore probably related to, the tuff of Mount Jefferson; they may represent products of Mount Jefferson caldera deposited during its waning stages.

- $26.65 \pm 0.07 \mathrm{Ma}\left({ }^{40} \mathrm{Ar} /{ }^{39} \mathrm{Ar}\right.$ on sanidine; this report)

The megabreccia of Bull Frame Canyon (Tbf) occupies a small area above volcaniclastic rocks of Little Table Mountain (Tlt). The megabreccia is lithologically similar to that of the tuff of Ryecroft Canyon (Trc) and is probably a local deposit of reworked megabreccia of Meadow Canyon (Tmc).

\section{Isom-Type Ash-Flow Tuff (Unit Ti)}

Locally, an ash-flow tuff unit (Ti) petrographically akin to the 27-Ma Isom Formation in eastern Nevada and western Utah (Best and others, 1989) apparently conformably overlies the volcaniclastic rocks of Little Table Mountain (Tlt). According to Best and others (1989), the Isom to the east is about $27 \mathrm{Ma}$; sanidine from a sample (RH-TP-616) of the tuff (Ti) collected in the northeast part of our study area gave $\mathrm{a}^{40} \mathrm{Ar} /{ }^{39} \mathrm{Ar}$ date of 27.22 $\pm 0.07 \mathrm{Ma}$. However, this date may not be accurate owing to excess ${ }^{40} \mathrm{Ar}$; the Isom-type unit clearly lies above the tuff of Mount Jefferson (Tmj) (27.07-26.69 Ma) and the overlying volcaniclastic rocks of Little Table Mountain (TIt) (26.65 Ma).

- $26.65 \mathrm{Ma}$ (volcaniclastic rocks of Little Table Mountain; this report)

- $27 \mathrm{Ma}$ (Isom Formation ash-fall tuff; Best and others, 1989)

- 27.07-26.69 Ma (tuff of Mount Jefferson; this report)

- $27.22 \pm 0.07 \mathrm{Ma}\left({ }^{40} \mathrm{Ar} /{ }^{39} \mathrm{Ar}\right.$ on sanidine; this report)

\section{Shingle Pass Tuff (Unit Tsp)}

The Shingle Pass Tuff (Tsp) in the southern Toquima Range consists of an upper and a lower member. The formation appears to be conformable upon Isom-type ashflow tuff (Ti) and conformable beneath unit $\mathrm{D}$ of the Bates Mountain Tuff (included in unit Ty, map plate this report). The upper member, however, is disconformable above the lower member. According to Best and others (1989) the upper member has a sanidine ${ }^{40} \mathrm{Ar} /{ }^{39} \mathrm{Ar}$ date of $26.00 \pm 0.03$ [26.19 \pm 0.03$] \mathrm{Ma}$ and the lower member has a sanidine ${ }^{40} \mathrm{Ar} /{ }^{39} \mathrm{Ar}$ date of $26.68 \pm 0.03$ [26.87 \pm 0.03$]$ Ma. The apparent notable interval between the ages of the two units may indicate that the lower member was considerably eroded before deposition of the upper member (separated locally by unit $\mathrm{D}$ of the Bates Mountain Tuff), as is true in the north-central part of our study area (Shawe, 1999b).

- $26.00 \pm 0.03[26.19 \pm 0.03] \mathrm{Ma}\left({ }^{40} \mathrm{Ar} /{ }^{39} \mathrm{Ar}\right.$ on sanidine, upper member; Best and others, 1989)

- $26.68 \pm 0.03[26.87 \pm 0.03] \mathrm{Ma}\left({ }^{40} \mathrm{Ar} /{ }^{39} \mathrm{Ar}\right.$ on sanidine, lower member; Best and others, 1989)

\section{Eruptive and Intrusive Rocks of the Manhattan Caldera and Associated Volcanic Units}

Early studies that referred to Tertiary igneous rocks in the southern Toquima Range (Ferguson, 1921, 1924; Ferguson and Cathcart, 1954) attempted correlation of these rocks with units identified outside the area. Ferguson (1924) originally assigned some of the silicic ash-flow tuffs in the Manhattan mining district to the Esmeralda Formation, a late Miocene to late Pliocene unit of somewhat similar lithology in the Tonopah district, $70 \mathrm{~km}$ south of the town of Manhattan, Nev. Ferguson considered the silicic ashflow tuffs to be rhyolite lava flows, although he recognized breccias, tuffs, and sandstones within the volcanic section. However, radiometric age studies by Shawe and others (1986) showed that the rocks in the southern Toquima Range are of latest Oligocene age (25.0 $0.8 \mathrm{Ma}, \mathrm{K}-\mathrm{Ar}$ on biotite). (Epochs as related to dates rely upon U.S. Geological Survey Geologic Names Committee, 2010.) The Round Rock Member of Ferguson's Esmeralda Formation was raised in rank to Round Rock Formation (Trr) and the name Esmeralda is not used in the southern Toquima Range (Shawe, 1987). Subsequently, Henry (1997) provided a ${ }^{40} \mathrm{Ar} /{ }^{39} \mathrm{Ar}$ date of 24.44 [24.63] $\pm 0.11 \mathrm{Ma}$ on sanidine from an ash-flow tuff of the Round Rock Formation in the south part of the Manhattan caldera.

- $24.44[24.63] \pm 0.11 \mathrm{Ma}\left({ }^{40} \mathrm{Ar} /{ }^{39} \mathrm{Ar}\right.$ on sanidine; Henry, 1997)

- $25.0 \pm 0.8 \mathrm{Ma}$ (K-Ar on biotite; Shawe and others, 1986) 
Ferguson (1924) recognized a breccia unit in his Round Rock Member, but he considered it to be a talus unit; he named it the Hedwig Breccia Member (name now abandoned) of the Esmeralda Formation. This unit was redefined as the megabreccia of Sloppy Gulch (Tsg), an eruptive ashflow megabreccia in the lower member of the Round Rock Formation (Trr) (Shawe, 1987; Shawe and Snyder, 1988).

Rhyolite blocks in a middle megabreccia unit of the Round Rock Formation (Shawe, 1987) were described by Ferguson (1924) as the Maris Rhyolite (name now abandoned). Ferguson and Cathcart (1954) subsequently correlated the Maris Rhyolite with the Oddie Rhyolite of the Tonopah area, also a Miocene formation. No radiometric age determinations have been made on rocks of the middle megabreccia unit of the Round Rock Formation. An inferred rhyolite-andesite volcanic neck was mapped within the Manhattan caldera near its southwest margin; the feature is interpreted as the source of the middle megabreccia member of the Round Rock Formation (Shawe, 1999a).

The Diamond King Member (Ferguson, 1924) of the Esmeralda Formation (Diamond King raised to formation rank by Shawe, 1987) overlies the Round Rock Formation (Trr) in the Manhattan caldera. The Diamond King Member was considered to be about $25 \mathrm{Ma}$ (Shawe, 1999a) because Shawe, Marvin, and others (1986) reported biotite K-Ar dates of $24.6 \pm 0.8 \mathrm{Ma}$ and $24.8 \pm 0.8 \mathrm{Ma}$ for the tuff of The Bald Sister (Tbs), which overlies the Diamond King. In a more recent study (published earlier than the Shawe (1999a) report), the ash-flow tuff of the Diamond King Formation (Tdk) from the east part of the Manhattan caldera was dated by ${ }^{40} \mathrm{Ar} /{ }^{39} \mathrm{Ar}$ on sanidine as 24.34 [24.53] $\pm 0.07 \mathrm{Ma}$ (Henry, 1997). Shawe (1998) speculated, on the basis of similar age and petrography, that the Diamond King correlates with the tuff of Arc Dome exposed in the Toiyabe Range about $35 \mathrm{~km}$ northeast of Manhattan (Brem and others, 1991; John, 1992), and was erupted from the Arc Dome caldera in the Toiyabe Range. Henry (1997), however, described the Diamond King as part of the tuffs that fill the Manhattan caldera, even though composition of the Diamond King is considerably different from the composition of the underlying Round Rock Formation within the caldera. Shawe and Byers (1999) described a crystal-rich tuff having a composition and age similar to those of the Diamond King; this tuff, which is exposed in the south part of the map area east of Ralston Valley and described as a crystal-rich, ash-flow tuff unit, Tos, also is likely equivalent to the Diamond King Formation (Tdk).

- $24.34[24.53] \pm 0.07 \mathrm{Ma}\left({ }^{40} \mathrm{Ar} /{ }^{39} \mathrm{Ar}\right.$ on sanidine; Henry, 1997)

- 24.6 $\pm 0.8 \mathrm{Ma}$ (K-Ar on biotite; Shawe and others, 1986)

- $24.8 \pm 0.8 \mathrm{Ma}$ (K-Ar on biotite; Shawe and others, 1986)

Immediately overlying the Diamond King Formation is a sequence of tuffaceous lakebed sediments and minor fluvial sandstone and conglomerate layers composed mostly of volcanic clasts. Ferguson (1924) designated the unit as Bald
Mountain Lake Beds Member of the Esmeralda Formation. Shawe (1987) revised the unit as the Bald Mountain Formation (Tbm). These materials probably were deposited in a shallow basin formed by minor collapse of the Manhattan caldera following the latest eruptions that produced the upper member of the Round Rock Formation and deposition of the Diamond King Formation.

An ash-flow tuff was designated as the quartz latite member of the Esmeralda Formation by Ferguson (1924), who considered these materials to be composed of lava flows; the tuff was deposited above the Bald Mountain Formation (Tbm). Radiometric age studies (K-Ar on biotite) provided dates of $24.8 \pm 0.8 \mathrm{Ma}$ and $24.6 \pm 0.8 \mathrm{Ma}$ for the unit (Shawe and others, 1986). Shawe (1987) tentatively correlated the unit with the tuff of Peavine Creek (Brem and Snyder, 1983) in the Toiyabe Range about $20 \mathrm{~km}$ west of Manhattan, Nev., on the basis of similar petrography and age. Subsequently, Shawe (1999a) renamed this tuff where it is exposed within the Manhattan caldera as the tuff of The Bald Sister (his unit Tbs).

- 24.6 $\pm 0.8 \mathrm{Ma}$ (K-Ar on biotite; Shawe and others, 1986)

- $24.8 \pm 0.8 \mathrm{Ma}$ (K-Ar on biotite; Shawe and others, 1986)

Two principal intrusive units were emplaced within the Manhattan caldera. An andesite that Ferguson and Cathcart (1954) designated Gilbert Andesite was correlated with a unit of that name in the Gilbert mining district $65 \mathrm{~km}$ southwest of Manhattan and was assigned to the Pliocene. According to Silberman and McKee (1972), the Gilbert in its type area is Miocene (15.1 $\pm 0.6 \mathrm{Ma}, \mathrm{K}-\mathrm{Ar}$ on sanidine(?)). An uncertain K-Ar date on plagioclase from what was Ferguson's (1924) Gilbert Andesite in the Manhattan caldera, now named Crone Gulch Andesite (Tca) by Shawe (1987), is $22.6 \pm 1.4 \mathrm{Ma}$ (earliest Miocene, but the range of uncertainty straddles the Oligocene-Miocene boundary of $23.03 \mathrm{Ma}$; Shawe and others, 1986). However, Shawe and Snyder (1988) inferred the unit to be latest Oligocene on the basis of geologic relations with dated units. A second intrusive unit was identified by Ferguson (1924) as dacite; Ferguson and Cathcart (1954) considered the unit to be an outlier of the Toiyabe Quartz Latite (name abandoned by John, 1992) exposed in the Toiyabe Range $30 \mathrm{~km}$ west of Manhattan. However, the Toiyabe in its type area consists mostly of ash-flow tuffs and cannot be correlated with the dacite intrusions in the Manhattan caldera. These rocks were designated dacite of Ferguson Hill (Tf) by Shawe (1987). Two radiometric age determinations have been made on a satellitic dike near the plugs of this unit; one K-Ar date on biotite is $25.5 \pm 0.9 \mathrm{Ma}$ and another on biotite is $23.5 \pm 0.8 \mathrm{Ma}$ (Shawe and others, 1986).

- $15.1 \pm 0.6 \mathrm{Ma}$ (K-Ar on sanidine(?); Silberman and McKee, 1972)

- 22.6土1.4 Ma (K-Ar on plagioclase; Ferguson, 1924)

- $23.5 \pm 0.8 \mathrm{Ma}$ (K-Ar on biotite; Shawe and others, 1986)

- $25.5 \pm 0.9 \mathrm{Ma}$ (K-Ar on biotite; Shawe and others, 1986) 
Several small rhyolite to rhyodacite plugs (Trd) were intruded into megabreccia along the east and northeast structural margins of the Manhattan caldera (Shawe, 1988). One of these plugs was dated (Shawe, 1988) as $24.8 \pm 0.9$ $\mathrm{Ma}$ (K-Ar on biotite). The Manhattan caldera also includes four associated eruptive megabreccia units (Shawe and Snyder, 1988).

- $24.8 \pm 0.9 \mathrm{Ma}$ (K-Ar on biotite; Shawe and Snyder, 1988)

\section{Bates Mountain Tuff (Unit TbtD), Tuff of Clipper Gap (Unit Tcg), and Tuff of Pipe Organ Spring (unit Tpo)}

Two ash-flow tuff units, unit D of the Bates Mountain Tuff (unit TbtD of Shawe and Byers, 1999, and tuff of Clipper Gap, unit Tcg of Shawe, 1999b), from different sources outside but near our mapped area, are similar to the tuff of Pipe Organ Spring (unit Tpo of Shawe, 1999b). Unit D (upper Oligocene-lower Miocene, on the basis of correlation with rocks in various localities outside our mapped area) consists mostly of crystal-poor rhyolitic ash-flow tuff and minor tuffaceous sediments, aggregating less than about 60 meters (m) in thickness. The tuff of Clipper Gap and the Bates Mountain Tuff have limited distributions in the map area (they are included in younger ash-flow tuffs, unit Ty, pl. 1). The tuff of Pipe Organ Spring (late Oligocene-early Miocene), named for a locality in the northeast part of our study area (Shawe, 1999b; Shawe, Hardyman, and Byers, 2000), is a crystal-poor rhyolitic ash-flow tuff mostly less than about $90 \mathrm{~m}$ thick. The tuff of Pipe Organ Spring consists locally of two members, an upper member (unit Tpu of Shawe, Hardyman, and Byers, 2000), and a lower member (unit Tpl of Shawe, 1999b), which appears to be equivalent, on the basis of petrographic similarity, to member 2 (unit Trt2) of Boden's tuffs and sedimentary rocks of Road Canyon (Boden, 1986, 1992), about $12 \mathrm{~km}$ north of our map area. The upper member of the tuff of Pipe Organ Spring (unit Tpu of Shawe, Hardyman, and Byers, 2000), is separated locally from the lower member (unit Tpl of Shawe, 1999b), by unit D of the Bates Mountain Tuff, mentioned earlier. A sanidine ${ }^{40} \mathrm{Ar} /{ }^{39} \mathrm{Ar}$ date (sample DRS-85-27) for the lower member is $25.49 \pm 0.05 \mathrm{Ma}$. Unit $\mathrm{D}$ of the Bates Mountain Tuff is similar to a unit in the lower member of Boden's tuffs of Road Canyon, for which he determined a sanidine K-Ar date of 23.6 $\pm 0.4 \mathrm{Ma}$ (Boden, 1986, 1992). However, a sample (DRS-91-74) (fig. 1) collected from a tuff unit in the lower part of Boden's Road Canyon section (Boden, 1986, 1992), and underlying a tuff unit similar to unit $D$ of the Bates Mountain Tuff, gave a sanidine age of $25.61 \pm 0.05$ Ma. The tuff of Clipper Gap (late Oligocene), which is similar to an upper member of the tuffs of Road Canyon near our study area and dated by Boden (1992) as $22.1 \pm 0.3 \mathrm{Ma}$, is a crystal-poor rhyolitic ash-flow tuff, generally less than $45 \mathrm{~m}$ thick.
- 22.1 $\pm 0.3 \mathrm{Ma}$ (tuff of Clipper Gap; Boden, 1992)

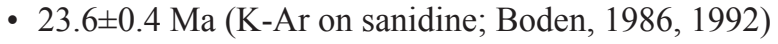

- $25.49 \pm 0.05 \mathrm{Ma}\left({ }^{40} \mathrm{Ar} /{ }^{39} \mathrm{Ar}\right.$ on sanidine; this report)

- $25.61 \pm 0.05 \mathrm{Ma}\left({ }^{40} \mathrm{Ar} /{ }^{39} \mathrm{Ar}\right.$ on sanidine; this report)

\section{Vitrophyric Ash-Fall Tuff (Unit Tva)}

A vitrophyric (glass-shard) ash-fall tuff (Tva) dated as 12.6 $\pm 2.6 \mathrm{Ma}$ (fission-track on zircon, Shawe, Naeser, and others, 1987) forms a small outcrop at the northwest edge of Ralston Valley (unit Tva, rhyolite volcanic ash, of Shawe, 1998). The vitrophyric tuff is from an unknown source (Shawe and others, 1987), possibly southeast of the southern Toquima Range.

- 12.6 $\pm 2.6 \mathrm{Ma}$ (fission-track on zircon; Shawe, Naeser, and others, 1987)

\section{${ }^{40} \mathrm{Ar} /{ }^{39} \mathrm{Ar}$ Geochronology of Volcanic Units}

Sixty mineral separates extracted from 28 rock samples from the Toquima Range, Nevada, were dated by the ${ }^{40} \mathrm{Ar}{ }^{39} \mathrm{Ar}$ agespectrum technique in the U.S. Geological Survey Denver Argon Laboratory. The new argon dates were determined by assuming a standard age of 28.03 Ma for Fish Canyon Tuff sanidine. Earlier reported ages for samples from the Toquima Range (Shawe, Hardyman, and Byers, 2000) analyzed in the Denver Argon Laboratory assumed a standard age of 27.84 Ma for Fish Canyon Tuff sanidine. Consequently, the earlier-determined ages must be increased by $0.19 \mathrm{Ma}$ to facilitate direct comparison with new data described herein. Ages recalculated in this fashion are enclosed in square brackets [ ] herein. The dated samples are primarily of Tertiary age; two Cretaceous-age clasts recovered from Tertiary breccias also were dated. Geochronology results are summarized in table 1 and raw data are presented in appendix 1. Standard procedures, summarized in the footnote of appendix 1 and by Snee (2002), were used to determine ages of the analyzed samples. New ${ }^{40} \mathrm{Ar} /{ }^{39} \mathrm{Ar}$ dates for numerous Toquima Range Tertiary volcanic rocks range from $33.35 \pm 0.06 \mathrm{Ma}$ to $24.92 \pm 0.05 \mathrm{Ma}$.

A sample of the tuff of Clipper Gap (Ty) (RH-TP-659) yielded biotite, hornblende, and sanidine separates. The biotite age spectrum (fig. $2 A$ ) defines a plateau that includes more than 72.9 percent of the released ${ }^{39} \mathrm{Ar}$, with an age of $24.88 \pm 0.05 \mathrm{Ma}$. The hornblende spectrum (fig. $2 B$ ) is slightly disturbed and saddle-shaped, and it indicates excess ${ }^{40} \mathrm{Ar}$; 42.2 percent of the released ${ }^{39} \mathrm{Ar}$ indicates a date of $24.85 \pm 0.18 \mathrm{Ma}$. The sanidine spectrum (fig. $2 \mathrm{C}$ ) indicates excess ${ }^{40} \mathrm{Ar}$, but more than 24.7 percent of the released ${ }^{39} \mathrm{Ar}$ suggests a date of $24.99 \pm 0.11 \mathrm{Ma}$. All of these apparent ages overlap within error, but because the biotite age spectrum is undisturbed, it provides our best estimate of the age of the tuff.

- $24.85 \pm 0.18 \mathrm{Ma}\left({ }^{40} \mathrm{Ar} /{ }^{39} \mathrm{Ar}\right.$ on hornblende; this report $)$

- $24.88 \pm 0.05 \mathrm{Ma}\left({ }^{40} \mathrm{Ar} /{ }^{39} \mathrm{Ar}\right.$ on biotite; this report $)$

- $24.99 \pm 0.11 \mathrm{Ma}\left({ }^{40} \mathrm{Ar} /{ }^{39} \mathrm{Ar}\right.$ on sanidine; this report) 
Table 1. Summary of ${ }^{40} \mathrm{Ar} /{ }^{39} \mathrm{Ar}$ dates for Toquima Range, Nevada, mineral separates.

$[\approx$, nearly equal to; Can., Canyon; Ma, million years ago]

\begin{tabular}{|c|c|c|c|c|c|c|}
\hline Sample & Description & Minerals & Latitude & Longitude & Character of spectrum & Date (Ma) and $1 \sigma$ error \\
\hline DRS-85-122 & Quartzite (prospect) ${ }^{1}$ & White mica & $38^{\circ} 42^{\prime} 36^{\prime \prime} \mathrm{N}$ & $116^{\circ} 58^{\prime} 47^{\prime \prime} \mathrm{W}$ & Preferred ${ }^{40} \mathrm{Ar}$ loss & $80.2 \pm 0.14$ \\
\hline DRS-85-128 & Porphyry clast (in Tjsi) ${ }^{2}$ & Actinolite & $38^{\circ} 42^{\prime} 30^{\prime \prime} \mathrm{N}$ & $116^{\circ} 58^{\prime} 12^{\prime \prime} \mathrm{W}$ & No plateau & $80 s$ \\
\hline DRS-85-176 & Andesite clast (in Tjsi) ${ }^{3}$ & Biotite & $38^{\circ} 42^{\prime} 20^{\prime \prime} \mathrm{N}$ & $116^{\circ} 58^{\prime} 03^{\prime \prime} \mathrm{W}$ & Plateau & $33.35 \pm 0.06$ \\
\hline DRS-85-176 & Andesite clast (in Tjsi) ${ }^{3}$ & Plagioclase & $38^{\circ} 42^{\prime} 20^{\prime \prime} \mathrm{N}$ & $116^{\circ} 58^{\prime} 03^{\prime \prime} \mathrm{W}$ & Preferred ${ }^{40} \mathrm{Ar}$ loss & $33.09 \pm 0.07$ \\
\hline DRS-92-1 & $\mathrm{Tjc}^{4}$ & Biotite & $38^{\circ} 43^{\prime} 24^{\prime \prime} \mathrm{N}$ & $117^{\circ} 01^{\prime} 10^{\prime \prime} \mathrm{W}$ & Plateau & $32.74 \pm 0.05$ \\
\hline DRS-92-1 & $\mathrm{Tjc} \mathrm{c}^{4}$ & Sanidine & $38^{\circ} 43^{\prime} 24^{\prime \prime} \mathrm{N}$ & $117^{\circ} 01^{\prime} 10^{\prime \prime} \mathrm{W}$ & Preferred-Excess ${ }^{40} \mathrm{Ar}$ & $32.81 \pm 0.06$ \\
\hline RH-TP-672 & Tuff of Haystack Canyon & Hornblende & $38^{\circ} 42^{\prime} 35^{\prime \prime} \mathrm{N}$ & $116^{\circ} 41^{\prime} 30^{\prime \prime} \mathrm{W}$ & Plateau & $29.70 \pm 0.12$ \\
\hline RH-TP-672 & Tuff of Haystack Canyon & Sanidine & $38^{\circ} 42^{\prime} 35^{\prime \prime} \mathrm{N}$ & $116^{\circ} 41^{\prime} 30^{\prime \prime} \mathrm{W}$ & Plateau & $29.87 \pm 0.07$ \\
\hline DRS-91-17 & Clast in $\mathrm{Tmb}^{5}$ & Biotite & $38^{\circ} 30^{\prime} 33^{\prime \prime} \mathrm{N}$ & $116^{\circ} 51^{\prime} 25^{\prime \prime} \mathrm{W}$ & Plateau & $27.51 \pm 0.05$ \\
\hline DRS-91-17 & Clast in Tmb ${ }^{5}$ & Hornblende & $38^{\circ} 30^{\prime} 33^{\prime \prime} \mathrm{N}$ & $116^{\circ} 51^{\prime} 25^{\prime \prime} \mathrm{W}$ & Preferred ${ }^{40} \mathrm{Ar}$ loss & $27.39 \pm 0.09$ \\
\hline DRS-91-17 & Clast in $\mathrm{Tmb}^{5}$ & Sanidine & $38^{\circ} 30^{\prime} 33^{\prime \prime} \mathrm{N}$ & $116^{\circ} 51^{\prime} 25^{\prime \prime} \mathrm{W}$ & Plateau & $27.24 \pm 0.06$ \\
\hline DRS-91-82 & Tec $(\text { Tccu })^{6}$ & Biotite & $38^{\circ} 41^{\prime} 11^{\prime \prime} \mathrm{N}$ & $116^{\circ} 49^{\prime} 41^{\prime \prime} \mathrm{W}$ & Plateau & $27.35 \pm 0.05$ \\
\hline DRS-91-82 & $\operatorname{Tcc}(\operatorname{Tccu})^{6}$ & Sanidine & $38^{\circ} 41^{\prime} 11^{\prime \prime} \mathrm{N}$ & $116^{\circ} 49^{\prime} 41^{\prime \prime} \mathrm{W}$ & Plateau & $27.36 \pm 0.06$ \\
\hline DRS-91-92 & Tmj breccia & Biotite & $38^{\circ} 41^{\prime} 20^{\prime \prime} \mathrm{N}$ & $116^{\circ} 50^{\prime} 49^{\prime \prime} \mathrm{W}$ & Plateau & $27.32 \pm 0.04$ \\
\hline DRS-91-31 & Trc & Biotite & $38^{\circ} 30^{\prime} 51^{\prime \prime} \mathrm{N}$ & $116^{\circ} 51^{\prime} 10^{\prime \prime} \mathrm{W}$ & Disturbed & Undetermined \\
\hline DRS-91-31 & Trc & Hornblende & $38^{\circ} 30^{\prime} 51^{\prime \prime} \mathrm{N}$ & $116^{\circ} 51^{\prime} 10^{\prime \prime} \mathrm{W}$ & Plateau & $26.85 \pm 0.14$ \\
\hline DRS-91-31 & Trc & Sanidine & $38^{\circ} 30^{\prime} 51^{\prime \prime} \mathrm{N}$ & $116^{\circ} 51^{\prime} 10^{\prime \prime} \mathrm{W}$ & Plateau & $27.01 \pm 0.04$ \\
\hline DRS-85-224 & Trc & Biotite & $38^{\circ} 38^{\prime} 39^{\prime \prime} \mathrm{N}$ & $116^{\circ} 58^{\prime} 07^{\prime \prime} \mathrm{W}$ & Disturbed & Undetermined \\
\hline DRS-85-224 & Trc & Sanidine & $38^{\circ} 38^{\prime} 39^{\prime \prime} \mathrm{N}$ & $116^{\circ} 58^{\prime} 07^{\prime \prime} \mathrm{W}$ & Plateau & $26.98 \pm 0.05$ \\
\hline DRS-85-225 & Trc & Sanidine & $38^{\circ} 36^{\prime} 27^{\prime \prime} \mathrm{N}$ & $116^{\circ} 50^{\prime} 26^{\prime \prime} \mathrm{W}$ & ${ }^{40} \mathrm{Ar}$ loss or excess ${ }^{40} \mathrm{Ar}$ & $\approx 27.32 \pm 0.08$ \\
\hline RH-TP-616 & $\mathrm{Ti}$ & Sanidine & $38^{\circ} 42^{\prime} 27^{\prime \prime} \mathrm{N}$ & $116^{\circ} 48^{\prime} 55^{\prime \prime} \mathrm{W}$ & Preferred-Excess ${ }^{40} \mathrm{Ar}$ & $27.22 \pm 0.07$ \\
\hline DRS-91-98 & Tmj $(\text { Tmjv })^{7}$ & Biotite & $38^{\circ} 41^{\prime} 49^{\prime \prime} \mathrm{N}$ & $116^{\circ} 50^{\prime} 59^{\prime \prime} \mathrm{W}$ & Plateau & $27.06 \pm 0.06$ \\
\hline DRS-91-98 & Tmj (Tmjv) 7 & Sanidine & $38^{\circ} 41^{\prime} 49^{\prime \prime} \mathrm{N}$ & $116^{\circ} 50^{\prime} 59^{\prime \prime} \mathrm{W}$ & Preferred ${ }^{40} \mathrm{Ar}$ loss & $27.07 \pm 0.05$ \\
\hline DRS-91-171 & Tmj & Biotite & $38^{\circ} 42^{\prime} 07^{\prime \prime} \mathrm{N}$ & $116^{\circ} 50^{\prime} 38^{\prime \prime} \mathrm{W}$ & Plateau & $27.10 \pm 0.04$ \\
\hline DRS-91-171 & $\mathrm{Tmj}$ & Hornblende & $38^{\circ} 42^{\prime} 07^{\prime \prime} \mathrm{N}$ & $116^{\circ} 50^{\prime} 38^{\prime \prime} \mathrm{W}$ & Preferred ${ }^{40} \mathrm{Ar}$ loss & $27.07+0.05$ \\
\hline DRS-91-171 & Tmj & Sanidine & $38^{\circ} 42^{\prime} 07^{\prime \prime} \mathrm{N}$ & $116^{\circ} 50^{\prime} 38^{\prime \prime} \mathrm{W}$ & Plateau & $26.83 \pm 0.05$ \\
\hline RH-TP-571 & Tmj & Biotite & $38^{\circ} 42^{\prime} 15^{\prime \prime} \mathrm{N}$ & $116^{\circ} 50^{\prime} 01^{\prime \prime} \mathrm{W}$ & Plateau & $27.02 \pm 0.07$ \\
\hline RH-TP-571 & Tmj & Sanidine & $38^{\circ} 42^{\prime} 15^{\prime \prime} \mathrm{N}$ & $116^{\circ} 50^{\prime} 01^{\prime \prime} \mathrm{W}$ & Plateau & $27.00 \pm 0.06$ \\
\hline RH-TP-583 & Tmj & Biotite & $38^{\circ} 42^{\prime} 36^{\prime \prime} \mathrm{N}$ & $116^{\circ} 50^{\prime} 06^{\prime \prime} \mathrm{W}$ & Plateau & $26.86+0.05$ \\
\hline RH-TP-583 & Tmj & Hornblende & $38^{\circ} 42^{\prime} 36^{\prime \prime} \mathrm{N}$ & $116^{\circ} 50^{\prime} 06^{\prime \prime} \mathrm{W}$ & Plateau & $26.69 \pm 0.04$ \\
\hline RH-TP-583 & Tmj & Sanidine & $38^{\circ} 42^{\prime} 36^{\prime \prime} \mathrm{N}$ & $116^{\circ} 50^{\prime} 06^{\prime \prime} \mathrm{W}$ & Plateau & $26.87 \pm 0.04$ \\
\hline RH-TP-590 & Tmj & Biotite & $38^{\circ} 43^{\prime} 30^{\prime \prime} \mathrm{N}$ & $116^{\circ} 49^{\prime} 10^{\prime \prime} \mathrm{W}$ & Plateau & $26.99+0.06$ \\
\hline RH-TP-590 & Tmj & Sanidine & $38^{\circ} 43^{\prime} 30^{\prime \prime} \mathrm{N}$ & $116^{\circ} 49^{\prime} 10^{\prime \prime} \mathrm{W}$ & Plateau & $26.85 \pm 0.04$ \\
\hline RH-TP-644 & Tmj & Biotite & $38^{\circ} 44^{\prime} 54^{\prime \prime} \mathrm{N}$ & $116^{\circ} 51^{\prime} 23^{\prime \prime} \mathrm{W}$ & Plateau & $27.08 \pm 0.04$ \\
\hline RH-TP-644 & Tmj & Hornblende & $38^{\circ} 44^{\prime} 54^{\prime \prime} \mathrm{N}$ & $116^{\circ} 51^{\prime} 23^{\prime \prime} \mathrm{W}$ & Plateau & $26.78+0.14$ \\
\hline RH-TP-644 & Tmj & Sanidine & $38^{\circ} 44^{\prime} 54^{\prime \prime} \mathrm{N}$ & $116^{\circ} 51^{\prime} 23^{\prime \prime} \mathrm{W}$ & Preferred ${ }^{40} \mathrm{Ar}$ loss & $26.83 \pm 0.07$ \\
\hline RH-TP-646 & $\mathrm{Tmj}$ & Biotite & $38^{\circ} 45^{\prime} 27^{\prime \prime} \mathrm{N}$ & $116^{\circ} 50^{\prime} 10^{\prime \prime} \mathrm{W}$ & Plateau & $26.93 \pm 0.07$ \\
\hline RH-TP-646 & Tmj & Sanidine & $38^{\circ} 45^{\prime} 27^{\prime \prime} \mathrm{N}$ & $116^{\circ} 50^{\prime} 10^{\prime \prime} \mathrm{W}$ & Plateau & $26.91 \pm 0.07$ \\
\hline DRS-85-48 & Tmj & Biotite & $38^{\circ} 41^{\prime} 19^{\prime \prime} \mathrm{N}$ & $116^{\circ} 59^{\prime} 18^{\prime \prime} \mathrm{W}$ & Plateau & $26.89+0.05$ \\
\hline DRS-85-48 & Tmj & Sanidine & $38^{\circ} 41^{\prime} 19^{\prime \prime} \mathrm{N}$ & $116^{\circ} 59^{\prime} 18^{\prime \prime} \mathrm{W}$ & Plateau & $26.86 \pm 0.04$ \\
\hline DRS-85-78 & Tmj(Tmjv) $)^{7}$ & Biotite & $38^{\circ} 43^{\prime} 27^{\prime \prime} \mathrm{N}$ & $116^{\circ} 58^{\prime} 39^{\prime \prime} \mathrm{W}$ & Plateau & $26.85 \pm 0.05$ \\
\hline DRS-85-78 & Tmj(Tmjv) ${ }^{7}$ & Sanidine & $38^{\circ} 43^{\prime} 27^{\prime \prime} \mathrm{N}$ & $116^{\circ} 58^{\prime} 39^{\prime \prime} \mathrm{W}$ & Plateau & $26.78+0.06$ \\
\hline DRS-85-10 & Tmj & Biotite & $38^{\circ} 41^{\prime} 57^{\prime \prime} \mathrm{N}$ & $116^{\circ} 55^{\prime} 56^{\prime \prime} \mathrm{W}$ & Plateau & $26.79 \pm 0.04$ \\
\hline DRS-85-10 & Tmj & Sanidine & $38^{\circ} 41^{\prime} 57^{\prime \prime} \mathrm{N}$ & $116^{\circ} 55^{\prime} 56^{\prime \prime} \mathrm{W}$ & Preferred ${ }^{40} \mathrm{Ar}$ loss & $26.78+0.05$ \\
\hline DRS-91-58A & Trp & Orthoclase & $38^{\circ} 41^{\prime} 52^{\prime \prime} \mathrm{N}$ & $116^{\circ} 50^{\prime} 02^{\prime \prime} \mathrm{W}$ & Plateau & $26.73+0.05$ \\
\hline DRS-92-16 & $\mathrm{Tlt}^{8}$ & Biotite & $38^{\circ} 42^{\prime} 29^{\prime \prime} \mathrm{N}$ & $116^{\circ} 50^{\prime} 48^{\prime \prime} \mathrm{W}$ & Disturbed & Undetermined \\
\hline DRS-92-16 & $\mathrm{Tlt}^{8}$ & Sanidine & $38^{\circ} 42^{\prime} 29^{\prime \prime} \mathrm{N}$ & $116^{\circ} 50^{\prime} 48^{\prime \prime} \mathrm{W}$ & Preferred-Excess ${ }^{40} \mathrm{Ar}$ & $26.47 \pm 0.05$ \\
\hline DRS-85-27 & Ty $(\mathrm{Tpl})^{9}$ & Biotite & $38^{\circ} 42^{\prime} 19^{\prime \prime} \mathrm{N}$ & $116^{\circ} 53^{\prime} 33^{\prime \prime} \mathrm{W}$ & Plateau & $27.36+0.05$ \\
\hline DRS-85-27 & Ty $(\mathrm{Tpl})^{9}$ & Hornblende & $38^{\circ} 42^{\prime} 19^{\prime \prime} \mathrm{N}$ & $116^{\circ} 53^{\prime} 33^{\prime \prime} \mathrm{W}$ & Plateau & $25.33 \pm 0.10$ \\
\hline DRS-85-27 & Ty $(\mathrm{Tpl})^{9}$ & Sanidine & $38^{\circ} 42^{\prime} 19^{\prime \prime} \mathrm{N}$ & $116^{\circ} 53^{\prime} 33^{\prime \prime} \mathrm{W}$ & Plateau & $25.49 \pm 0.05$ \\
\hline DRS-92-59 & Ty $(\text { Tpl })^{9}$ & Biotite & $38^{\circ} 42^{\prime} 23^{\prime \prime} \mathrm{N}$ & $116^{\circ} 52^{\prime} 57^{\prime \prime} \mathrm{W}$ & Disturbed & $\approx 26.3 \overline{5} \pm 0.06$ \\
\hline DRS-92-59 & Ty $(\mathrm{Tpl})^{9}$ & Hornblende & $38^{\circ} 42^{\prime} 23^{\prime \prime} \mathrm{N}$ & $116^{\circ} 52^{\prime} 57^{\prime \prime} \mathrm{W}$ & Plateau & $25.71 \pm 0.15$ \\
\hline DRS-92-59 & Ty $(\mathrm{Tpl})^{9}$ & Orthoclase & $38^{\circ} 42^{\prime} 23^{\prime \prime} \mathrm{N}$ & $116^{\circ} 52^{\prime} 57^{\prime \prime} \mathrm{W}$ & Plateau & $25.57 \pm 0.05$ \\
\hline DRS-91-74 & Ty (tuffs of Road Can.) ${ }^{10}$ & Biotite & $38^{\circ} 51^{\prime} 29^{\prime \prime} \mathrm{N}$ & $116^{\circ} 51^{\prime} 04^{\prime \prime} \mathrm{W}$ & Disturbed & $26.13+0.08$ \\
\hline DRS-91-74 & Ty (tuffs of Road Can.) & Sanidine & $38^{\circ} 51^{\prime} 29^{\prime \prime} \mathrm{N}$ & $116^{\circ} 51^{\prime} 04^{\prime \prime} \mathrm{W}$ & Plateau & $25.61 \pm 0.05$ \\
\hline DRS-85-54 & Ty(Tspl $)^{11}$ & Biotite & $38^{\circ} 43^{\prime} 03^{\prime \prime} \mathrm{N}$ & $116^{\circ} 52^{\prime} 35^{\prime \prime} \mathrm{W}$ & Disturbed & $\approx 26.0 \overline{0}+0.05$ \\
\hline DRS-85-54 & Ty(Tspl) ${ }^{11}$ & Sanidine & $38^{\circ} 43^{\prime} 03^{\prime \prime} \mathrm{N}$ & $116^{\circ} 52^{\prime} 35^{\prime \prime} \mathrm{W}$ & Plateau & $25.13+0.19$ \\
\hline RH-TP-659 & Ty $(\text { Tcg })^{12}$ & Biotite & $38^{\circ} 42^{\prime} 54^{\prime \prime} \mathrm{N}$ & $116^{\circ} 49^{\prime} 15^{\prime \prime} \mathrm{W}$ & Plateau & $24.88 \pm 0.05$ \\
\hline RH-TP-659 & Ty(Tcg) $)^{12}$ & Hornblende & $38^{\circ} 42^{\prime} 54^{\prime \prime} \mathrm{N}$ & $116^{\circ} 49^{\prime} 15^{\prime \prime} \mathrm{W}$ & Preferred-Excess ${ }^{40} \mathrm{Ar}$ & $24.85+0.18$ \\
\hline RH-TP-659 & Ty(Tcg) ${ }^{12}$ & Sanidine & $38^{\circ} 42^{\prime} 54^{\prime \prime} \mathrm{N}$ & $116^{\circ} 49^{\prime} 15^{\prime \prime} \mathrm{W}$ & Preferred-Excess ${ }^{40} \mathrm{Ar}$ & $24.99+0.11$ \\
\hline
\end{tabular}

${ }^{1}$ Mineralized quartzite, Gold Hill Formation (Cgq, Shawe, 1999b), from prospect dump.

${ }^{2}$ Porphyritic granite clast in intrusive phase of megabreccia of Jefferson Summit (Tjsi, Shawe, 1999b).

${ }^{3}$ Andesite clast in intrusive phase of megabreccia of Jefferson Summit (Tjsi, Shawe, 1999b).

${ }^{4}$ Vitrophyric matrix(?) at base of megabreccia of Jefferson (Tjc, Shawe, 1995).

${ }^{5}$ Clast in monolithologic megabreccia (Tmb, Shawe and others, 2000).

${ }^{6}$ Tuff of Corcoran Canyon (Tcc), upper unit (Shawe and others, 2000).

${ }^{7}$ Tuff of Mount Jefferson, vitrophyre unit (Tmjv, Shawe, 1999b).

${ }^{8}$ Biotite-rich layer in fine-grained tuffaceous sandstone-siltstone in volcaniclastic rocks of Little Table Mountain (Tltl, Shawe, 1999b).

${ }^{9}$ Tuff of Pipe Organ Spring, lower (Tpl, Shawe, 1999b), in Ty.

${ }^{10}$ Grayish-buff layered tuff in lower part of tuffs of Road Canyon, just northeast of our map area (Boden, 1986).

${ }^{11}$ Shingle Pass Tuff, lower (Tspl, Shawe, 1999b), in Ty.

${ }^{12}$ Tuff of Clipper Gap (Tcg, Shawe and others, 2000), in Ty. 

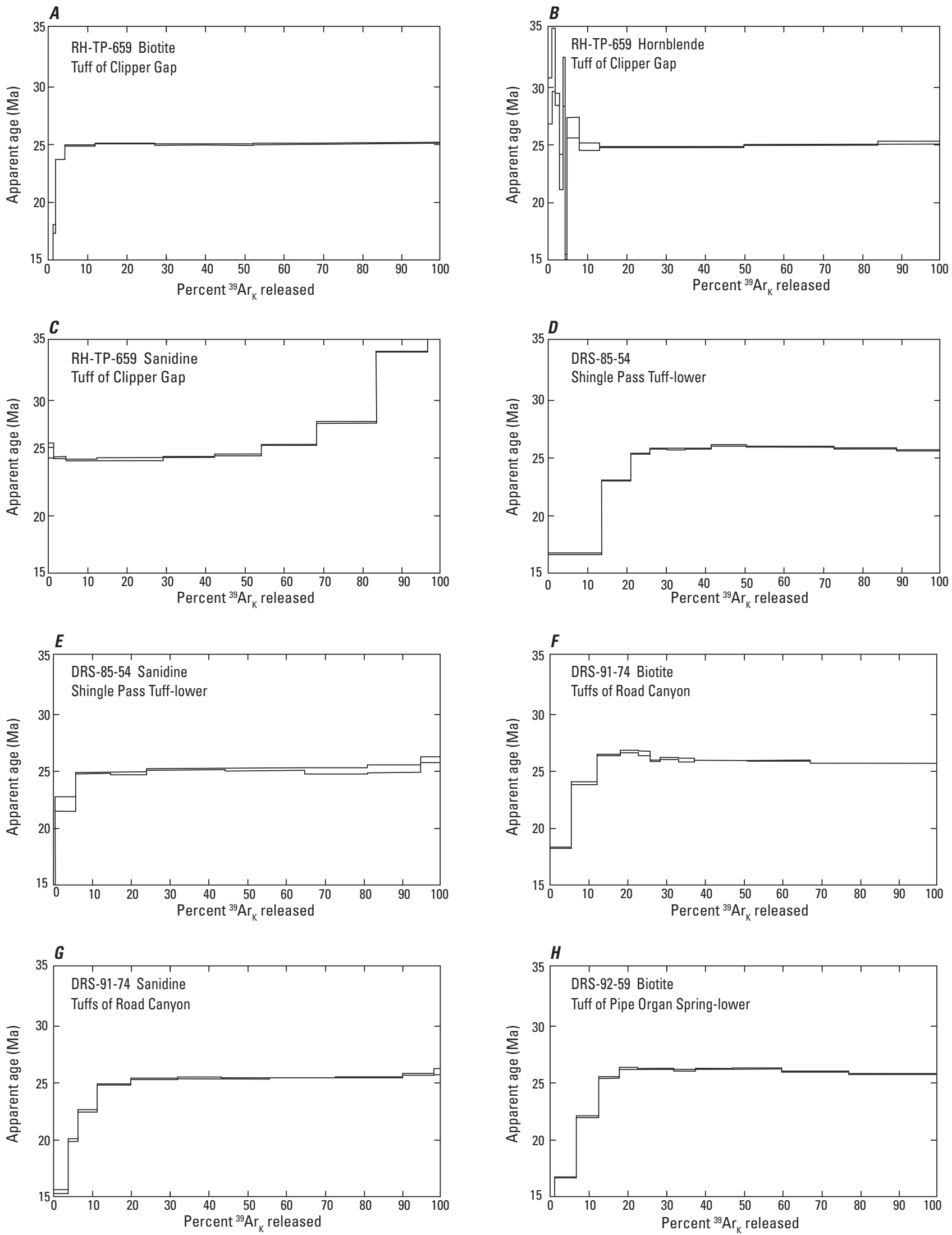

Figure 2 (above and following pages). ${ }^{40} \mathrm{Ar} /{ }^{39} \mathrm{Ar}$ age spectra of minerals in volcanic rocks of the southern Toquima Range, Nye County, Nevada. Letters $A$ through $H H H$ correspond with the identifier in upper left of each view and link to discussion in text. 

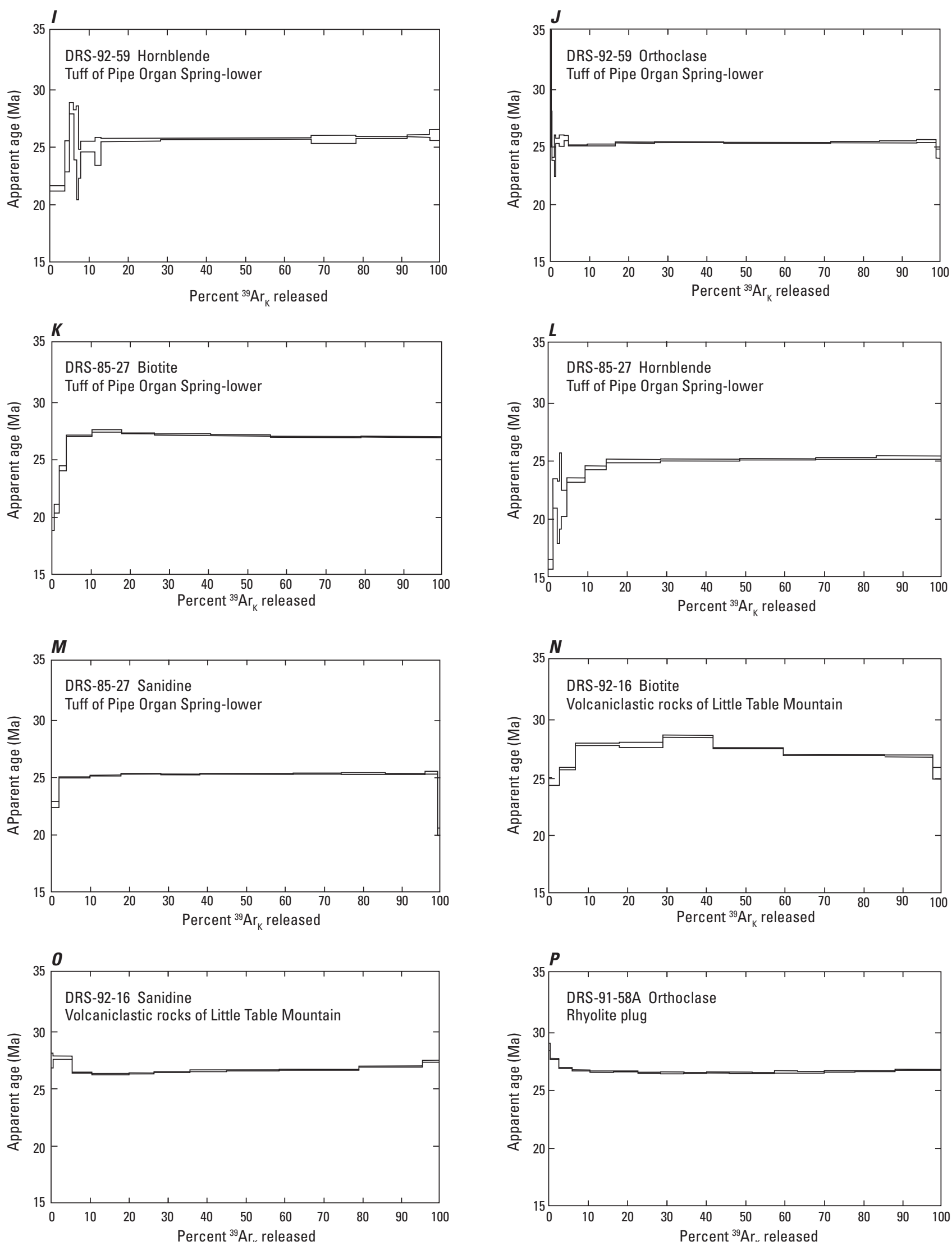

Figure 2. ${ }^{40} \mathrm{Ar} /{ }^{39} \mathrm{Ar}$ age spectra of minerals in volcanic rocks of the southern Toquima Range, Nye County, Nevada. Letters $A$ through $H H H$ correspond with the identifier in upper left of each view and link to discussion in text.-Continued 

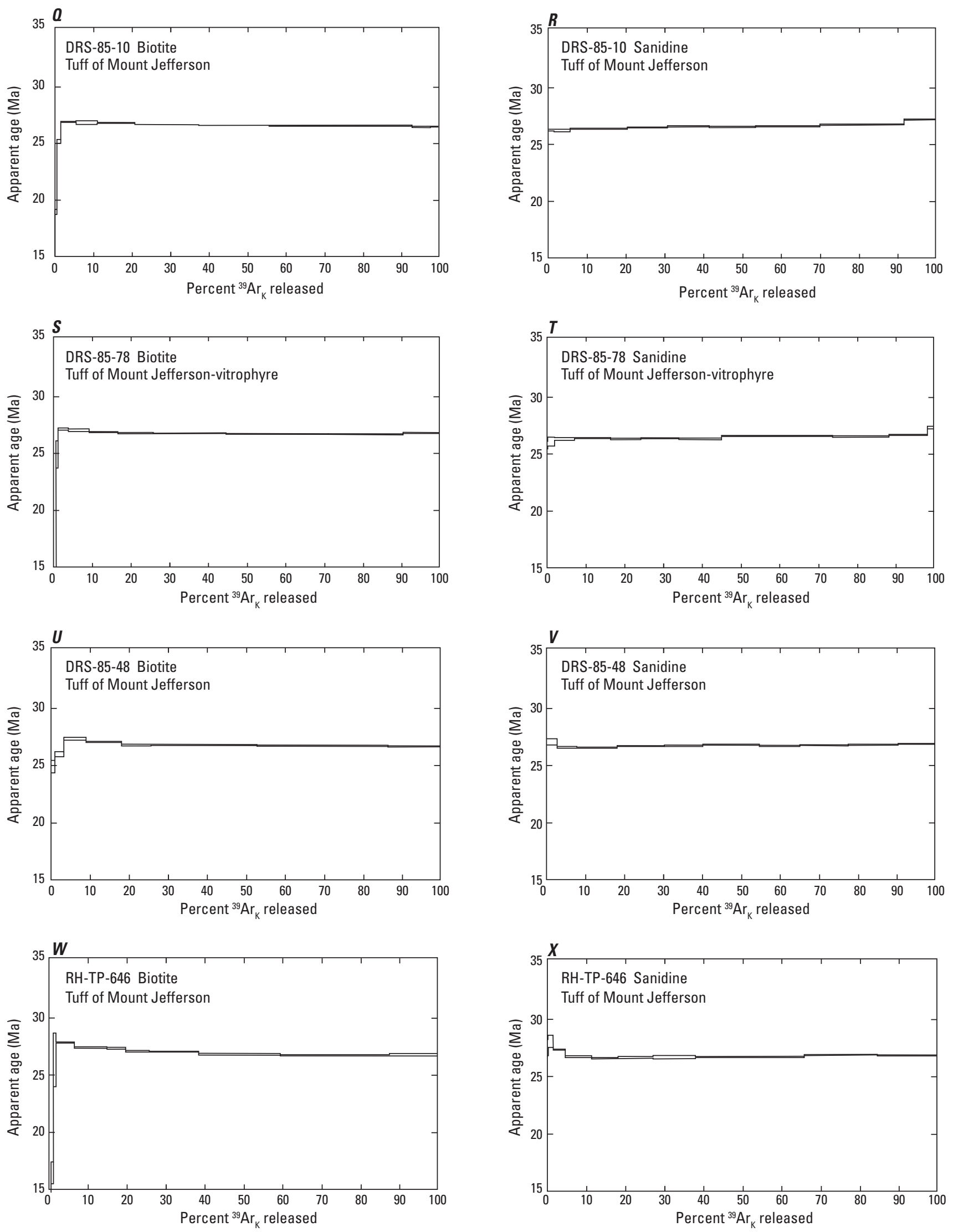

Figure 2. ${ }^{40} \mathrm{Ar} /{ }^{39} \mathrm{Ar}$ age spectra of minerals in volcanic rocks of the southern Toquima Range, Nye County, Nevada. Letters $A$ through $\mathrm{HHH}$ correspond with the identifier in upper left of each view and link to discussion in text.-Continued 

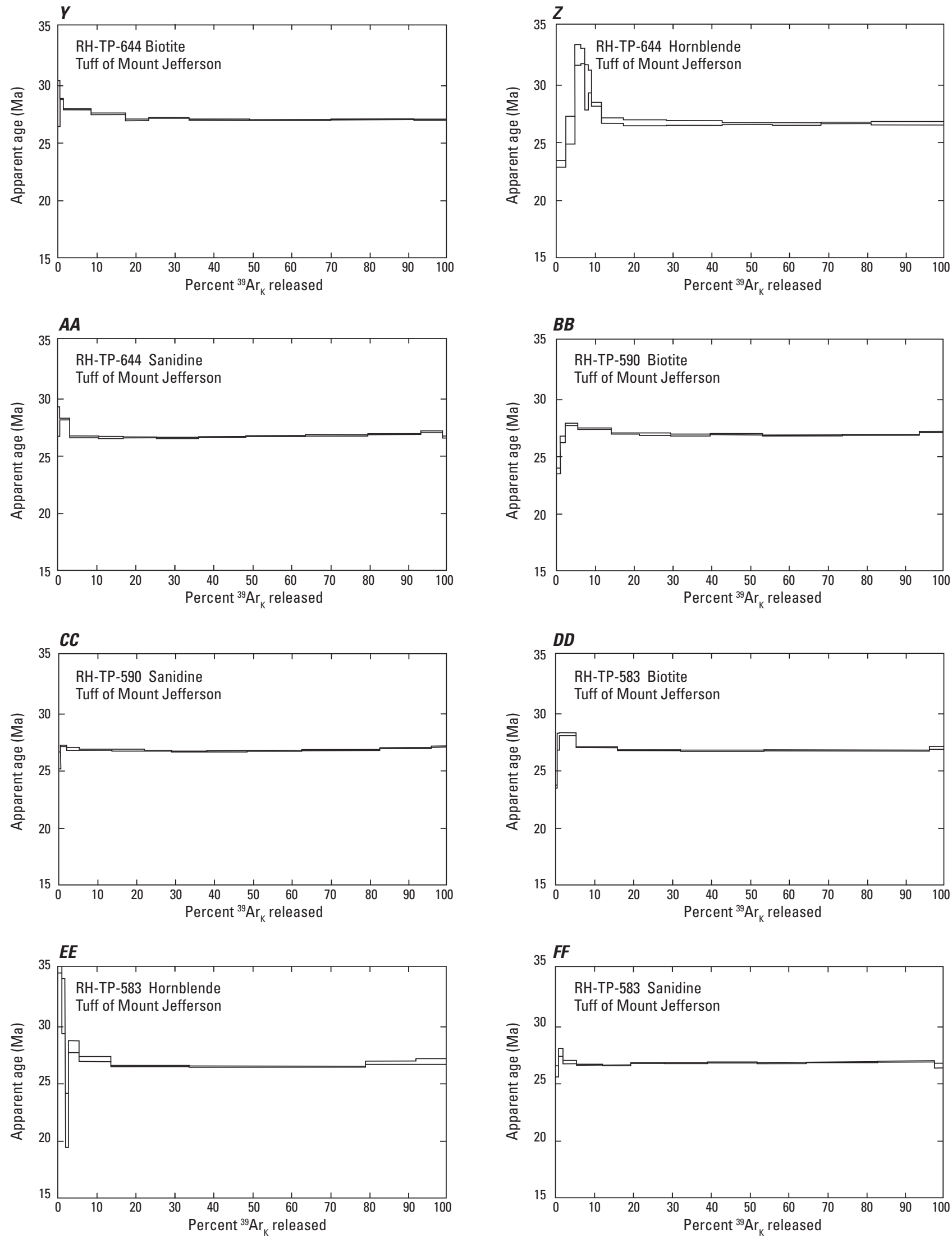

Figure 2. ${ }^{40} \mathrm{Ar} /{ }^{39} \mathrm{Ar}$ age spectra of minerals in volcanic rocks of the southern Toquima Range, Nye County, Nevada. Letters $A$ through $\mathrm{HHH}$ correspond with the identifier in upper left of each view and link to discussion in text.-Continued 

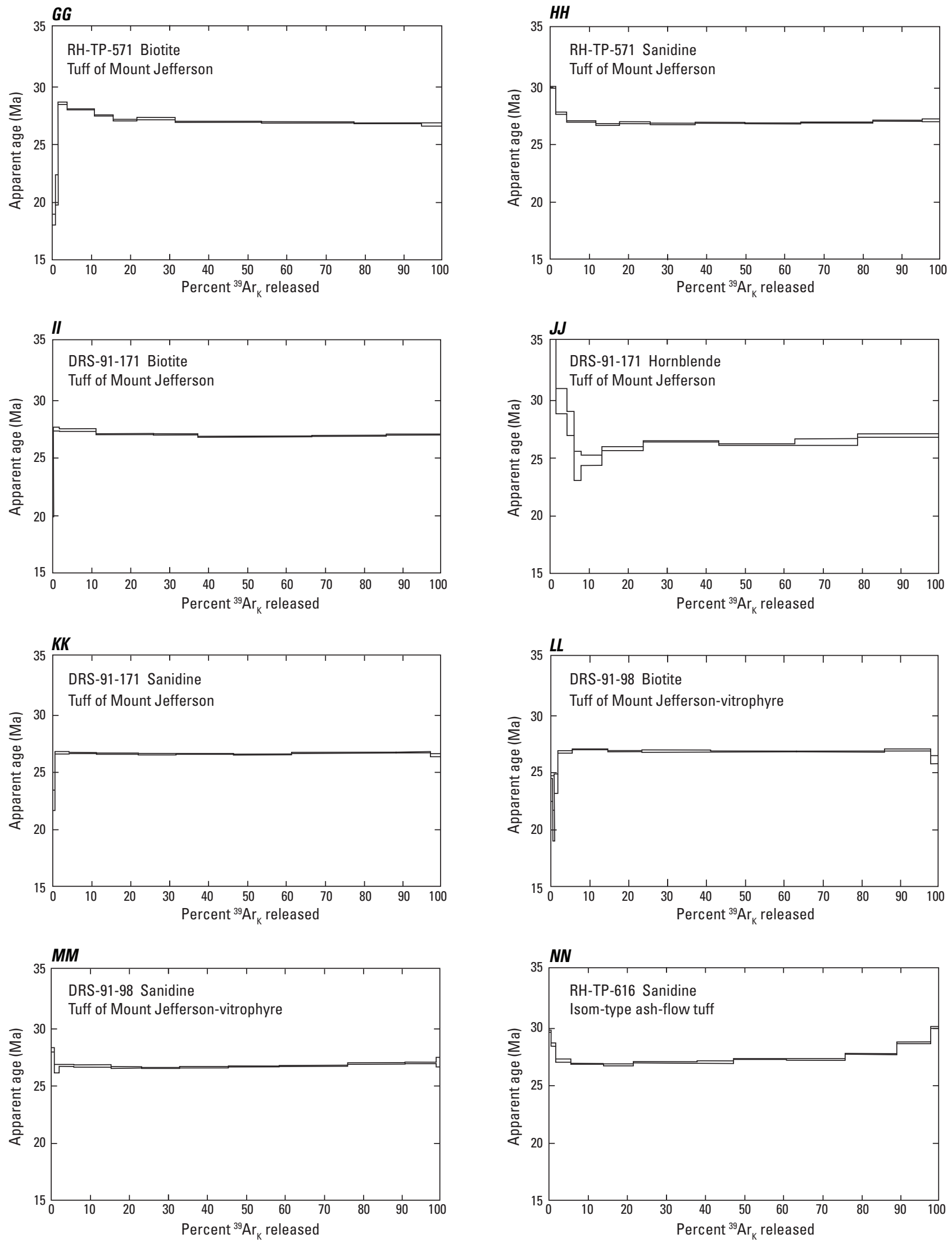

Figure 2. ${ }^{40} \mathrm{Ar} /{ }^{39} \mathrm{Ar}$ age spectra of minerals in volcanic rocks of the southern Toquima Range, Nye County, Nevada. Letters $A$ through $H H H$ correspond with the identifier in upper left of each view and link to discussion in text.-Continued 

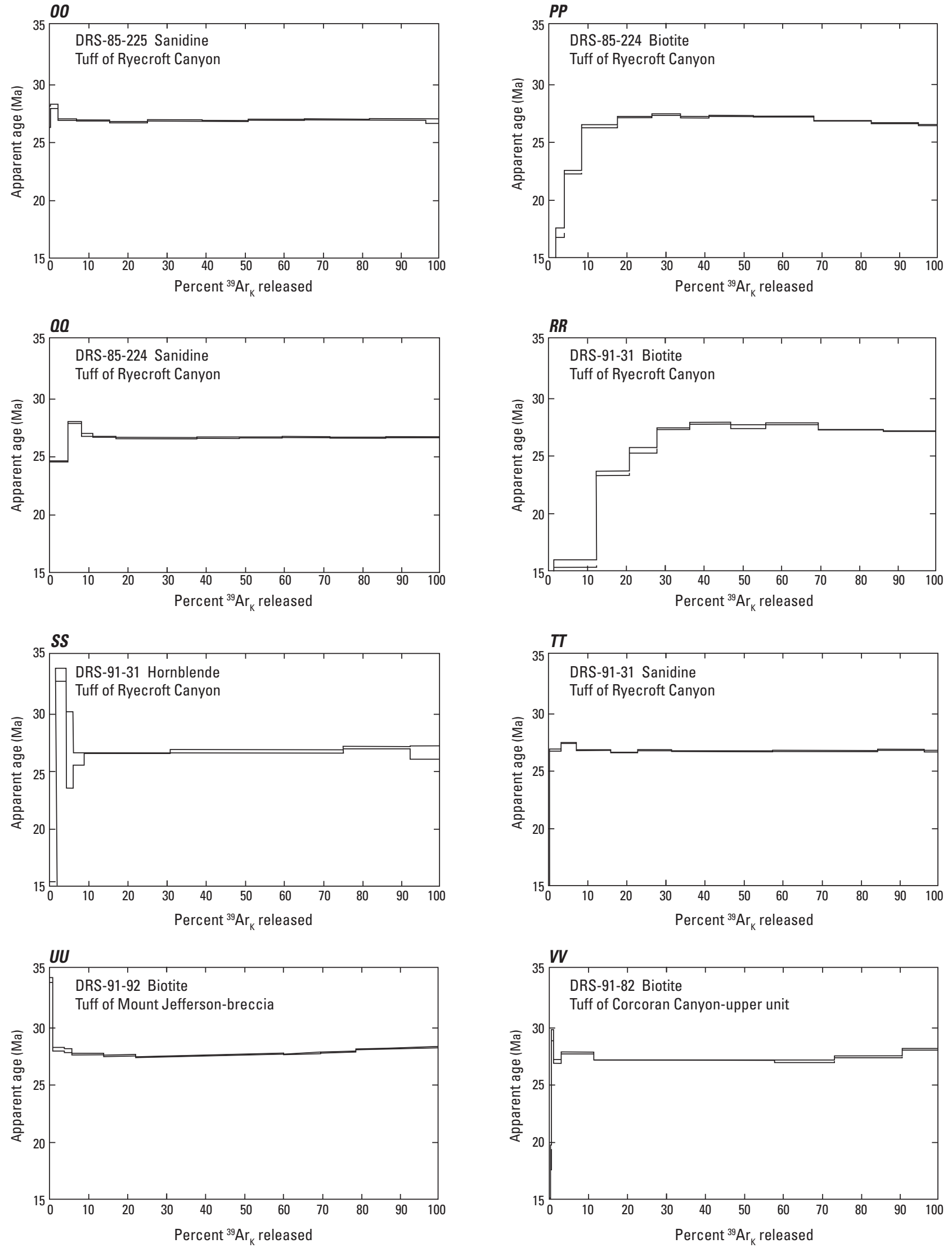

Figure 2. ${ }^{40} \mathrm{Ar} /{ }^{39} \mathrm{Ar}$ age spectra of minerals in volcanic rocks of the southern Toquima Range, Nye County, Nevada. Letters $A$ through $\mathrm{HHH}$ correspond with the identifier in upper left of each view and link to discussion in text.-Continued 

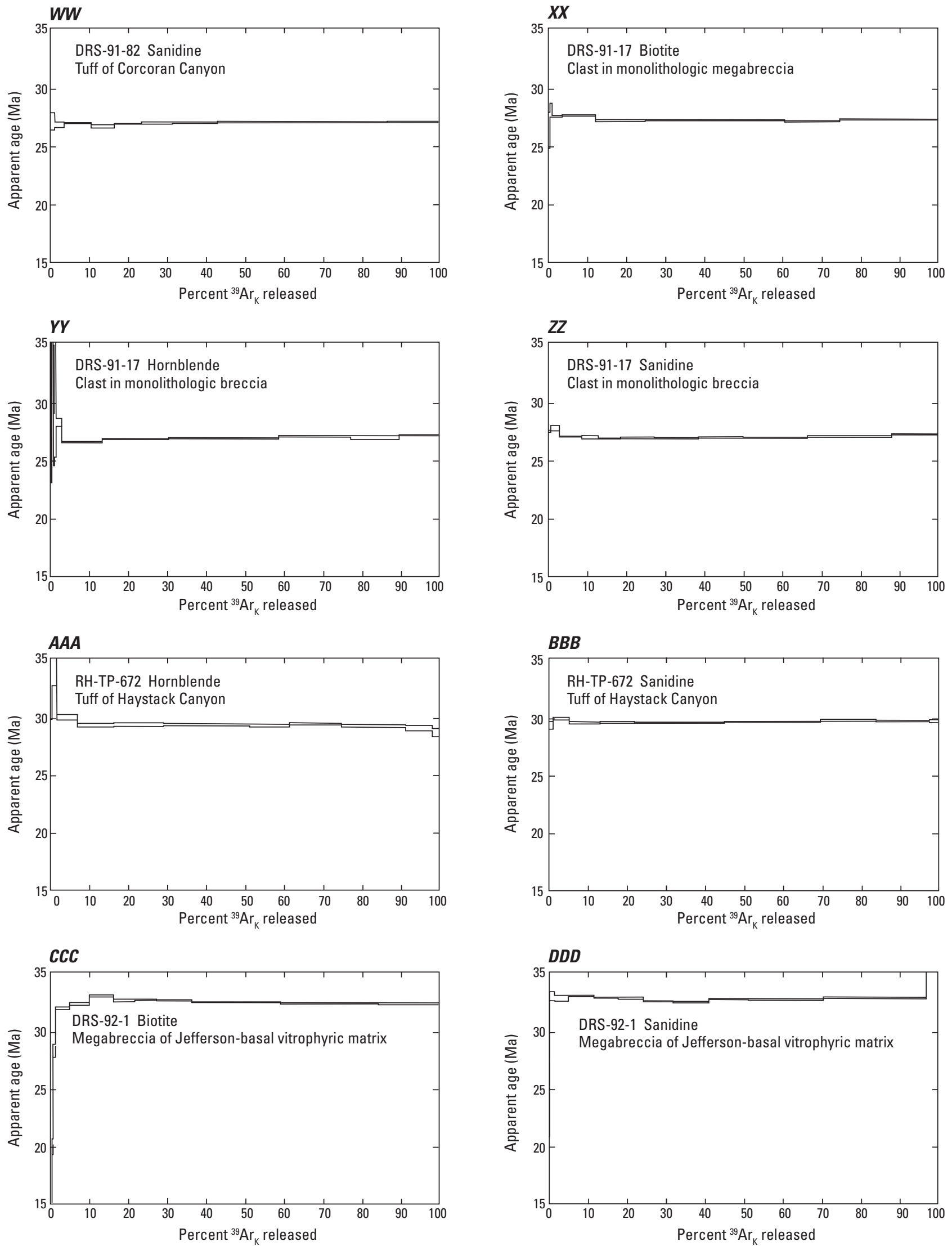

Figure 2. ${ }^{40} \mathrm{Ar} /{ }^{39} \mathrm{Ar}$ age spectra of minerals in volcanic rocks of the southern Toquima Range, Nye County, Nevada. Letters $A$ through $\mathrm{HHH}$ correspond with the identifier in upper left of each view and link to discussion in text.-Continued 

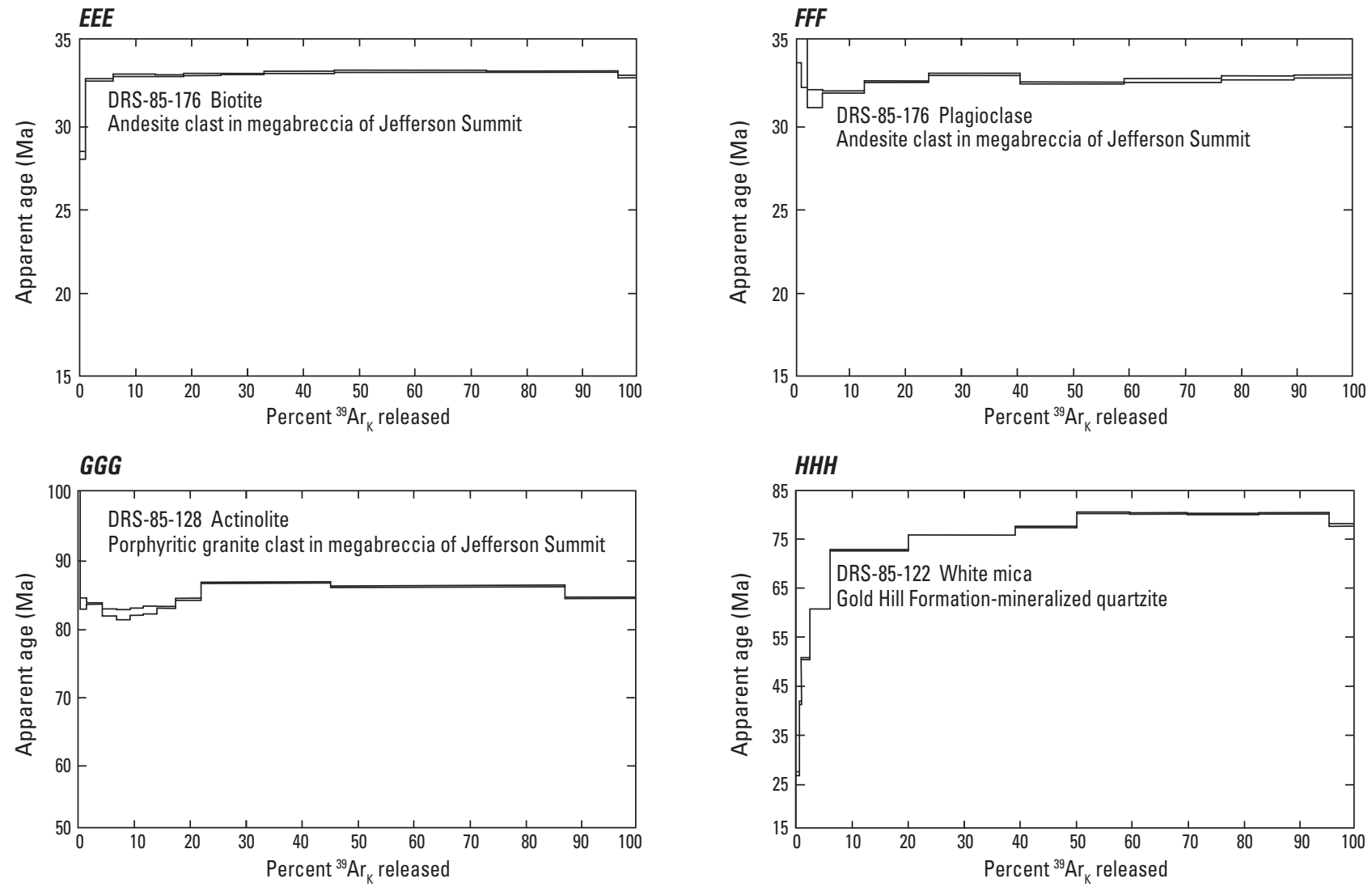

Figure 2. ${ }^{40} \mathrm{Ar} /{ }^{39} \mathrm{Ar}$ age spectra of minerals in volcanic rocks of the southern Toquima Range, Nye County, Nevada. Letters $A$ through $\mathrm{HHH}$ correspond with the identifier in upper left of each view and link to discussion in text.-Continued

A sample from the lower part of the Shingle Pass Tuff (Tsp) (DRS-85-54) yielded biotite and sanidine separates. The biotite age spectrum (fig. $2 D$ ) is slightly disturbed and includes an excess ${ }^{40} \mathrm{Ar}$ hump, likely the result of minor secondary chlorite. Analytical issues caused the sanidine to produce a low isotopic signal; however, the sample yielded a plateau (fig. 2E) that includes more than 70.7 percent of the released ${ }^{39} \mathrm{Ar}$ with a date of $25.13 \pm 0.19 \mathrm{Ma}$, which is our best estimate for the age of the unit.

- $25.13 \pm 0.19 \mathrm{Ma}\left({ }^{40} \mathrm{Ar} /{ }^{39} \mathrm{Ar}\right.$ on sanidine; this report)

A sample of the tuff of Road Canyon (DRS-91-74; fig. 1) collected in Road Canyon $12 \mathrm{~km}$ north of our map area yielded biotite and sanidine separates. The biotite argon spectrum (fig. $2 F$ ) is disturbed but the sanidine (fig. $2 G$ ) yielded a plateau age of $25.61 \pm 0.05 \mathrm{Ma}$, which is our best estimate for the age of the tuff.

- $25.61 \pm 0.05 \mathrm{Ma}\left({ }^{40} \mathrm{Ar} /{ }^{39} \mathrm{Ar}\right.$ on sanidine; this report)

Two samples of the tuff of Pipe Organ Spring (Ty) were analyzed. Sample DRS-92-59 yielded orthoclase, hornblende, and biotite separates. The biotite spectrum indicates excess ${ }^{40} \mathrm{Ar}$ (fig. $2 H$ ); the hornblende (fig. $2 I$ ) and orthoclase (fig. $2 J$ ) spectra include plateaus of $25.71 \pm 0.15 \mathrm{Ma}$ and 25.57 $\pm 0.05 \mathrm{Ma}$, respectively. Sample DRS-85-27 biotite (fig. $2 K$ ), hornblende (fig. $2 L$ ) and sanidine (fig. $2 M$ ) plateau dates are $25.36 \pm 0.05,25.33 \pm 0.10$, and $25.49 \pm 0.05 \mathrm{Ma}$, respectively. The age spread among these analyses may reflect real age differences or routine analytical error. Our preference is to average these four dates to obtain an average arithmetic age of $25.53 \pm 0.16 \mathrm{Ma}$ for the tuff of Pipe Organ Spring.

- $25.33 \pm 0.10\left({ }^{40} \mathrm{Ar} /{ }^{39} \mathrm{Ar}\right.$ on hornblende; this report $)$

- $25.36 \pm 0.05\left({ }^{40} \mathrm{Ar} /{ }^{39} \mathrm{Ar}\right.$ on biotite; this report)

- $25.49 \pm 0.05 \mathrm{Ma}\left({ }^{40} \mathrm{Ar} /{ }^{39} \mathrm{Ar}\right.$ on sanidine; this report $)$

- $25.53 \pm 0.16 \mathrm{Ma}\left({ }^{40} \mathrm{Ar} /{ }^{39}\right.$ average age; this report)

- $25.57 \pm 0.05 \mathrm{Ma}\left({ }^{40} \mathrm{Ar} /{ }^{39} \mathrm{Ar}\right.$ on orthoclase; this report)

- $25.71 \pm 0.15 \mathrm{Ma}\left({ }^{40} \mathrm{Ar} /{ }^{39} \mathrm{Ar}\right.$ on hornblende; this report)

Biotite (fig. $2 \mathrm{~N}$ ) and sanidine (fig. $2 \mathrm{O}$ ) separates from sample DRS-92-16 of the Little Table Mountain unit (TIt) yielded disturbed age spectra. The biotite date is unreliable. However, the sanidine spectrum, although it indicates minor excess ${ }^{40} \mathrm{Ar}$, defines an apparent age of $26.47 \pm 0.05 \mathrm{Ma}$ in its low-age segment, which we consider to be the best estimate of the age of the unit.

- $26.47 \pm 0.05 \mathrm{Ma}\left({ }^{40} \mathrm{Ar} /{ }^{39} \mathrm{Ar}\right.$ on sanidine; this report $)$

An orthoclase separate from a rhyolite plug (Trp), sample DRS-91-58A, yielded an argon plateau date of $26.73 \pm 0.05 \mathrm{Ma}$ (fig. $2 P$ ), our accepted date for alteration of the intrusion.

- $26.73 \pm 0.05 \mathrm{Ma}\left({ }^{40} \mathrm{Ar} /{ }^{39} \mathrm{Ar}\right.$ on orthoclase; this report) 
Twenty-one of the dated mineral separates (sanidine, biotite, and hornblende) from 10 Mount Jefferson samples range in age from 27.07 Ma to 26.69; an additional Mount Jefferson sample is a vitrophyre that produced sanidine and biotite separates with apparent ages in this same range (figs. $2 Q-M M$ ). Of the 23 samples, 18 yield plateau age spectra with a mean age of $26.90 \pm 0.10(1 \sigma) \mathrm{Ma}$. Of the 5 samples that did not produce plateaus, 4 are sanidine that indicate gradually increasing age with increasing release temperature, which is a common characteristic of sanidine age spectra; our preferred ages for these 4 samples are also coincident with the age range defined by the 18 samples included in the mean age. The fifth sample is hornblende, separated from vitrophyre, that produced an ${ }^{40} \mathrm{Ar}$ loss spectrum that steps up in apparent age to $27.07 \mathrm{Ma}$, which is identical to the age of coexisting biotite from the vitrophyre. The average of all 21 apparent ages is $26.90 \pm 0.11(1 \sigma)$ Ma. The 0.38 -m.y. range of ages among the 21 samples may represent analytical error or, alternatively, may reflect the true duration of eruptive activity responsible for the tuff of Mount Jefferson (Tmj).

- 26.90 $\pm 0.11(1 \sigma) \mathrm{Ma}\left(\right.$ mean age ${ }^{40} \mathrm{Ar} /{ }^{39} \mathrm{Ar}$ on tuff; this report)

- $27.07 \mathrm{Ma}\left({ }^{40} \mathrm{Ar} r{ }^{39} \mathrm{Ar}\right.$ on hornblende; this report)

Sanidine from sample RH-TP-616 collected from the Isom-type ash-flow tuff (Ti) defines a disturbed age spectrum that indicates excess ${ }^{40} \mathrm{Ar}$. The low-age part of the agespectrum saddle yields an apparent age of $27.22 \pm 0.07(1 \sigma)$ $\mathrm{Ma}$ (fig. $2 N N$ ). However, the presence of excess ${ }^{40} \mathrm{Ar}$ suggests that the preferred age may be older than the actual eruption age.

- $27.22 \pm 0.07(1 \sigma) \mathrm{Ma}\left({ }^{40} \mathrm{Ar} /{ }^{39} \mathrm{Ar}\right.$ on tuff; this report $)$

Three samples of the tuff of Ryecroft Canyon (Trc) yielded sanidine (fig. 2OO) (DRS-85-225), biotite (fig. 2PP) and sanidine (fig. 2QQ) (DRS-85-224), and biotite (fig. 2RR), hornblende (fig. 2SS), and sanidine (fig. 2TT) (DRS-91-31) separates that were analyzed. Both biotite age spectra are strongly disturbed and produce indeterminate results. The sanidine age spectrum for sample DRS-85-225 is difficult to interpret because it reflects characteristics of either ${ }^{40} \mathrm{Ar}$ loss or excess ${ }^{40} \mathrm{Ar}$. Sanidine from sample DRS-85-224, and sanidine and hornblende from sample DRS-91-31 produced plateau spectra with an average age of $26.95 \pm 0.08(1 \sigma) \mathrm{Ma}$.

- $26.95 \pm 0.08(1 \sigma) \mathrm{Ma}$ (average age, ${ }^{40} \mathrm{Ar} /{ }^{\beta 9} \mathrm{Ar}$ on tuff; this report)

Biotite in sample DRS-91-92 from a breccia clast contained in the tuff of Mount Jefferson (Tmj) yielded an argon spectrum (fig. 2UU) indicative of minor excess ${ }^{40} \mathrm{Ar}$ but includes a plateau with an apparent age of $27.32 \pm 0.04(1 \sigma) \mathrm{Ma}$. We interpret this plateau to be the age of the clast and therefore a maximum age for the enclosing tuff.

- $27.32 \pm 0.04(1 \sigma) \mathrm{Ma}\left({ }^{40} \mathrm{Ar} /{ }^{39} \mathrm{Ar}\right.$ on biotite; this report $)$

Sample DRS-91-82, tuff of Corcoran Canyon (Tcc), yielded biotite (fig. $2 \mathrm{VV}$ ) and sanidine (fig. $2 \mathrm{WW}$ ) separates that produced concordant apparent plateau ages of $27.35 \pm 0.05(1 \sigma)$ and 27.36 $\pm 0.06(1 \sigma) \mathrm{Ma}$, respectively. The average of these dates is our preferred age for eruption of the Corcoran Canyon tuff.

- $27.35 \pm 0.05(1 \sigma) \mathrm{Ma}\left({ }^{40} \mathrm{Ar} /{ }^{39} \mathrm{Ar}\right.$ on biotite; this report $)$

- $27.36 \pm 0.06(1 \sigma) \mathrm{Ma}\left({ }^{40} \mathrm{Ar} /{ }^{39} \mathrm{Ar}\right.$ on sanidine; this report $)$

Biotite (fig. $2 X X$ ), hornblende (fig. $2 Y Y$ ), and sanidine (fig. 2ZZ) separates were recovered from and ${ }^{40} \mathrm{Ar} /{ }^{39} \mathrm{Ar}$ ages determined for a sample (DRS-91-17) of the monolithologic megabreccia $(\mathrm{Tmb})$. The hornblende spectrum indicates ${ }^{40} \mathrm{Ar}$ loss and defines a near plateau age of $27.39 \pm 0.09(1 \sigma) \mathrm{Ma}$ (fig. 2YY). Biotite and sanidine separates yielded plateaus with apparent ages of $27.51 \pm 0.05(1 \sigma)$ and $27.24 \pm 0.06(1 \sigma) \mathrm{Ma}$, respectively. The biotite and sanidine dates are statistically distinct and the hornblende date is intermediate. The average of these three dates, $27.38 \pm 0.14(1 \sigma) \mathrm{Ma}$, probably represents the best estimate of the age of this unit. Alternatively, because the biotite and sanidine ages are statistically distinct their age discordance may indicate geologic processes rather than analytical error. Thus, the biotite apparent age may represent the best age of the monolithologic megabreccia (Tmb) because the amphibole and sanidine age spectra both indicate ${ }^{40} \mathrm{Ar}$ loss.

- $27.24 \pm 0.06(1 \sigma) \mathrm{Ma}\left({ }^{40} \mathrm{Ar} /{ }^{39} \mathrm{Ar}\right.$ on sanidine; this report $)$

- $27.38 \pm 0.14(1 \sigma) \mathrm{Ma}$ (average age, ${ }^{40} \mathrm{Ar} /{ }^{39} \mathrm{Ar}$ on sanidine; this report)

- $27.39 \pm 0.09(1 \sigma) \mathrm{Ma}\left({ }^{40} \mathrm{Ar}{ }^{39} \mathrm{Ar}\right.$ on hornblende; this report $)$

- $27.51 \pm 0.05(1 \sigma)\left({ }^{40} \mathrm{Ar} /{ }^{39} \mathrm{Ar}\right.$ on biotite; this report)

Sample RH-TP-672 (fig. 1) was collected in the nearby Monitor Range and represents the informally named tuff of Haystack Canyon (R.F. Hardyman, oral commun., 2012). Hornblende (fig. $2 A A A$ ) and sanidine (fig. $2 B B B$ ) separates yielded concordant dates of $27.70 \pm 0.12(1 \sigma)$ and $27.87 \pm 0.07(1 \sigma) \mathrm{Ma}$, respectively. The average apparent age of $27.79 \pm 0.10(1 \sigma) \mathrm{Ma}$ is our estimate of the age of the tuff.

- $27.79 \pm 0.10(1 \sigma) \mathrm{Ma}$ (average age, ${ }^{40} \mathrm{Ar} /{ }^{39} \mathrm{Ar}$ on tuff; this report)

- $27.70 \pm 0.12(1 \sigma)\left({ }^{40} \mathrm{Ar} /{ }^{39} \mathrm{Ar}\right.$ on hornblende; this report $)$

- $27.87 \pm 0.07(1 \sigma) \mathrm{Ma}\left({ }^{40} \mathrm{Ar} /{ }^{39} \mathrm{Ar}\right.$ on sanidine; this report)

A sample of Jefferson Canyon megabreccia (Tjc) (DRS-92-1) yielded a biotite plateau age (fig. 2CCC) of $32.74 \pm 0.05(1 \sigma) \mathrm{Ma}$ and a sanidine preferred age (fig. $2 D D D$ ) of $32.81 \pm 0.06(1 \sigma) \mathrm{Ma}$. The sanidine age spectrum is disturbed and indicates either ${ }^{40} \mathrm{Ar}$ loss or excess ${ }^{40} \mathrm{Ar}$. Therefore the biotite date is our best estimate for the age of this unit.

- $32.74 \pm 0.05(1 \sigma) \mathrm{Ma}\left({ }^{40} \mathrm{Ar} /{ }^{39} \mathrm{Ar}\right.$ on biotite; this report $)$

- $32.81 \pm 0.06(1 \sigma) \mathrm{Ma}\left({ }^{40} \mathrm{Ar} /{ }^{39} \mathrm{Ar}\right.$ on sanidine; this report)

Sample DRS-85-176 is from an andesite porphyry clast in the intrusive phase of megabreccia of Jefferson Summit (Tjs) from which biotite (fig. 2EEE) and plagioclase (fig. 2FFF) separates were obtained. The plagioclase age spectrum is disturbed, but the biotite produced an age spectrum with a plateau age of 33.35 $\pm 0.06(1 \sigma)$ Ma, our accepted age.

- $33.35 \pm 0.06(1 \sigma) \mathrm{Ma}\left({ }^{40} \mathrm{Ar} /{ }^{39} \mathrm{Ar}\right.$ on biotite; this report) 
Sample DRS-85-128 represents clasts in the intrusive phase of the megabreccia of Jefferson Summit (Tjs). Actinolite from DRS-85-128 yielded a disturbed argon spectrum (fig. $2 G G G$ ) with an apparent Late Cretaceous age. Argon derived from muscovite in DRS-85-122 produced an argon-loss spectrum (fig. $2 \mathrm{HHH}$ ) with an interpreted age of $80.2 \pm 0.1(1 \sigma) \mathrm{Ma}$, which is a reasonable estimate for the cooling age of the muscovite.

- $80.2 \pm 0.1(1 \sigma) \mathrm{Ma}\left({ }^{40} \mathrm{Ar} /{ }^{39} \mathrm{Ar}\right.$ on muscovite; this report)

\section{Phenocryst Compositions as Determined by Electron Microprobe}

\section{Analytical Methods, Mineral Structural Formula Calculations, and Samples Analyzed}

Polished thin sections of selected samples were prepared to determine compositions of plagioclase, sanidine, biotite, hornblende, clinopyroxene, and orthopyroxene phenocrysts by electron microprobe analysis. Not all of these minerals were present or analyzed in each of the samples examined. Resulting microprobe analyses were used to calculate mineral structural formulas.

Phenocryst compositions were determined using a JEOL $8900 \circledR$ electron microprobe with 5 wavelengthdispersive crystal spectrometers, 5-20 micrometer $(\mu \mathrm{m})$ beam, 15 kilovolt $(\mathrm{kV})$ accelerating voltage, and 20 nanoampere (nA) beam current were used to make 20 -second analyses on numerous grains of each mineral species. Analyzed spots were at grain cores and rims, and in some instances at intermediate spots to ensure that the full composition range of each mineral was recorded. In tables of analytical data (appendixes 2-8), "Probe sample no." entries ending in " 1 " identify grain core analyses, whereas " 2 " indicates grain rim analyses, and " 3 " or "4" indicate analyses of intermediate parts of grains.

Microprobe determinations report total iron in biotite in the ferrous $\left(\mathrm{Fe}^{2+}\right)$ state. Prior to structural formula calculation total iron was partitioned to $\mathrm{Fe}^{2+}$ and $\mathrm{Fe}^{3+}$ by assuming $\mathrm{Fe}^{2+} /\left(\mathrm{Fe}^{2+}+\mathrm{Fe}^{3+}\right)=0.85$ (Dodge and others, 1969); $\mathrm{H}_{2} \mathrm{O}$ abundances were determined by stoichiometry by assuming 24 anions $(\mathrm{O}, \mathrm{OH}, \mathrm{F}, \mathrm{Cl})$.

Microprobe determinations report total iron in amphibole in the ferrous $\left(\mathrm{Fe}^{2+}\right)$ state. As part of structural formula calculations, total iron was partitioned to $\mathrm{Fe}^{2+}$ and $\mathrm{Fe}^{3+}$ by charge balancing; $\mathrm{H}_{2} \mathrm{O}$ abundances were determined by stoichiometry assuming 24 anions $(\mathrm{O}, \mathrm{OH}, \mathrm{F}, \mathrm{Cl})$. Amphibole names were assigned according to the classification of Leake and others (1997). Compositions of each of the minerals analyzed are presented in variation diagrams (figs. 3-27).

Several volcanic units were selected for phenocryst composition determinations in order to confirm the identity or correlation of their host units. Studied were Isom-type tuff (Ti) (3 samples), Bates Mountain Tuff (Ty) (3 samples), tuff of Mount Jefferson (Tmj) (8 samples, identified in the next section, including 5 from a unit identified as tuff of
Trail Canyon by Boden (1986), which we believe is part of the tuff of Mount Jefferson), tuff of Ryecroft Canyon (Trc) (3 samples), tuff of Corcoran Canyon (Tcc) (2 samples), and megabreccia of Jefferson Canyon (1 sample). The megabreccia of Jefferson Canyon (Tjc) was described by Boden (1986) as the megabreccia of Dry Canyon and correlated by Henry (1997) with a 32.3 Ma caldera underlying Big Smoky Valley.

\section{Results of Phenocryst Analyses}

Phenocryst compositions are discussed in subsequent sections by individual volcanic unit: megabreccia of Jefferson Canyon (Tjc), tuff of Corcoran Canyon (Tcc), tuff of Ryecroft Canyon (Trc), tuff of Mount Jefferson (Tmj), Isom-type tuff (Ti), and Bates Mountain Tuff (Ti). Phenocryst composition variations may mimic the compositional variations of host magmas arrayed in vertically zoned reservoirs; during single eruptions magma may have been derived from multiple zones. In most cases, because of the relatively limited number of samples studied and the relative uncertainty of each sample's stratigraphic position (general position estimated for tuff of Mount Jefferson samples), interpreting the nature and extent of magma evolution and eruptive histories are possible to a limited extent only. However, the data provide evidence that in some of the formations studied, conditions prevailing during phenocryst crystallization varied between eruptive episodes, attesting to likely derivation of magma from different levels in zoned reservoirs. Although geologic evidence implies more than one cooling unit (representing discrete eruptive episodes) in some formations, and there is petrographic evidence of compositional variation in magma during an episode, the data are generally insufficient to define the nature and extent of magma evolution during the petrogenesis of individual ash-flow tuffs. However, mineral composition data define magma composition characteristics pertinent to the histories of the different formations, and the data bear on proposed unit correlations. Locations of samples for which mineral compositions were determined are shown on plate 1 and figure 1 .

\section{Megabreccia of Jefferson Canyon (Unit Tjc)}

We determined phenocryst compositions in only one sample (vitrophyre, DRS-92-1; figs. 3-6) of the megabreccia of Jefferson Canyon (Tjc). The vitrophyric sample was collected where the rock appears to be a basal chilled ash matrix of the megabreccia. Accordingly, the ages of its contained phenocrysts probably define the age of the vitrophyre and the associated megabreccia. Alternatively, the vitrophyre may constitute a large clast derived from an older unit, in which case phenocrysts would not be representative of the megabreccia. The compositions of biotite, amphibole, and pyroxene phenocrysts were determined by microprobe analysis and are compared here to those in the tuff of Mount Jefferson (Tmj), described in later paragraphs.

Biotite compositions shown in figure 3 are virtually identical to those of $\mathrm{Mg}$-rich biotites in samples from the lower part of the tuff of Mount Jefferson (see later discussion 
of fig. 12) and are more Mg-rich than samples from the upper part of the tuff of Mount Jefferson (see later discussion of figs. 13, 14). The similarity of biotite compositions suggests that the megabreccia of Jefferson Canyon (Tjc) is akin to the lower part of the tuff of Mount Jefferson. The composition of one biotite in the vitrophyre of sample DRS-92-1

(fig. 3), which plots off the general trend, may represent an inaccurate analysis.

Compositions of hornblende in sample DRS-92-1 (fig. 4) lie along the less Ca-rich hornblende composition trend defined for tuff of Mount Jefferson (Tmj) samples (see later discussion of fig. 16), and appear to be most akin to the older (lower) part of the tuff of Mount Jefferson. Amphibole in the sample is composed of edenite and pargasite/ magnesiohastingsite (see later discussion of fig. 5).

Compositions of augite in the sample of the megabreccia of Jefferson Canyon (Tjc) (DRS-92-1, fig. 6) are virtually identical to those of clinopyroxene in tuff of Mount Jefferson samples (see subsequent discussion of fig. 19).

Compositional similarities among biotite, hornblende, and augite in the megabreccia of Jefferson Canyon (Tjc) and those in the tuff of Mount Jefferson (Tmj) suggest that the two units had a common magma source. If this correlation is correct, then the inference that the megabreccia is related to the Mount Jefferson caldera, as suggested earlier by Shawe (1995, 1999b) and by Shawe, Hardyman, and Byers (2000), is corroborated. The $32 \mathrm{Ma}$ dates for the megabreccia of Jefferson Canyon obtained by Boden (1986, 1992), Henry (1997), and Shawe (1999b) may represent older material

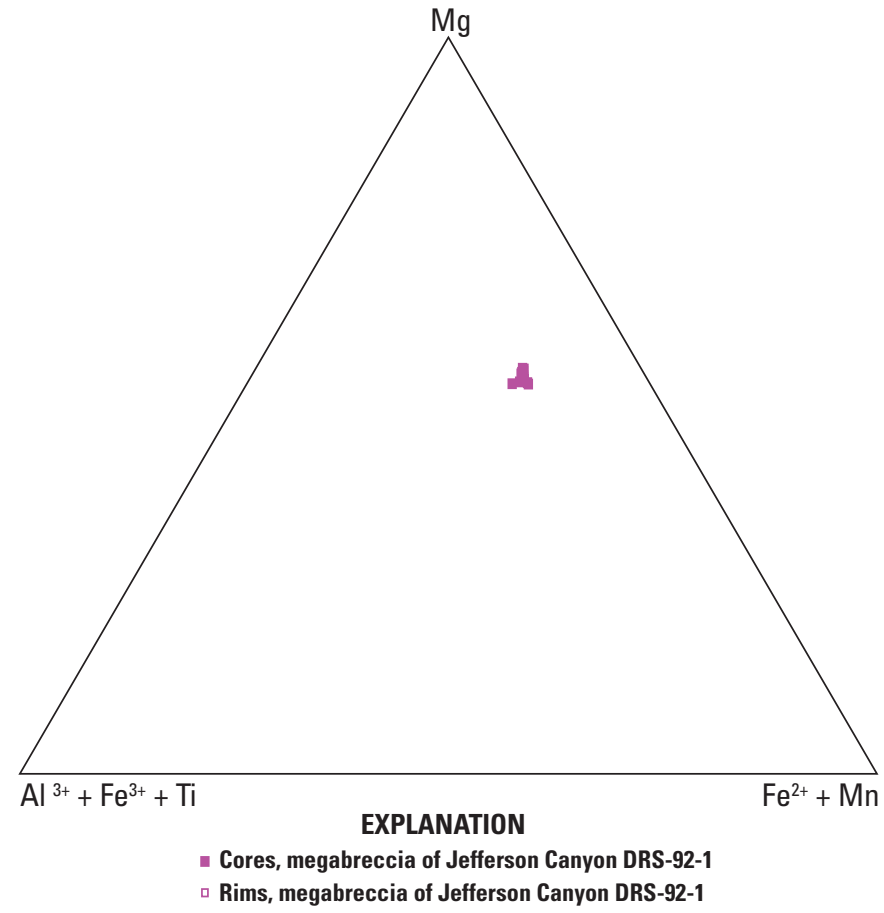

Figure 3. Ternary diagram of $\mathrm{Mg}-\mathrm{Al}^{3+}+\mathrm{Fe}^{3+}+\mathrm{Ti}-\mathrm{Fe}^{2+}+\mathrm{Mn}$ showing relative cation abundances in biotite of one sample, southern Toquima Range, Nye County, Nevada (Sample DRS-92-1; unit Tgs of Shawe, 1995)

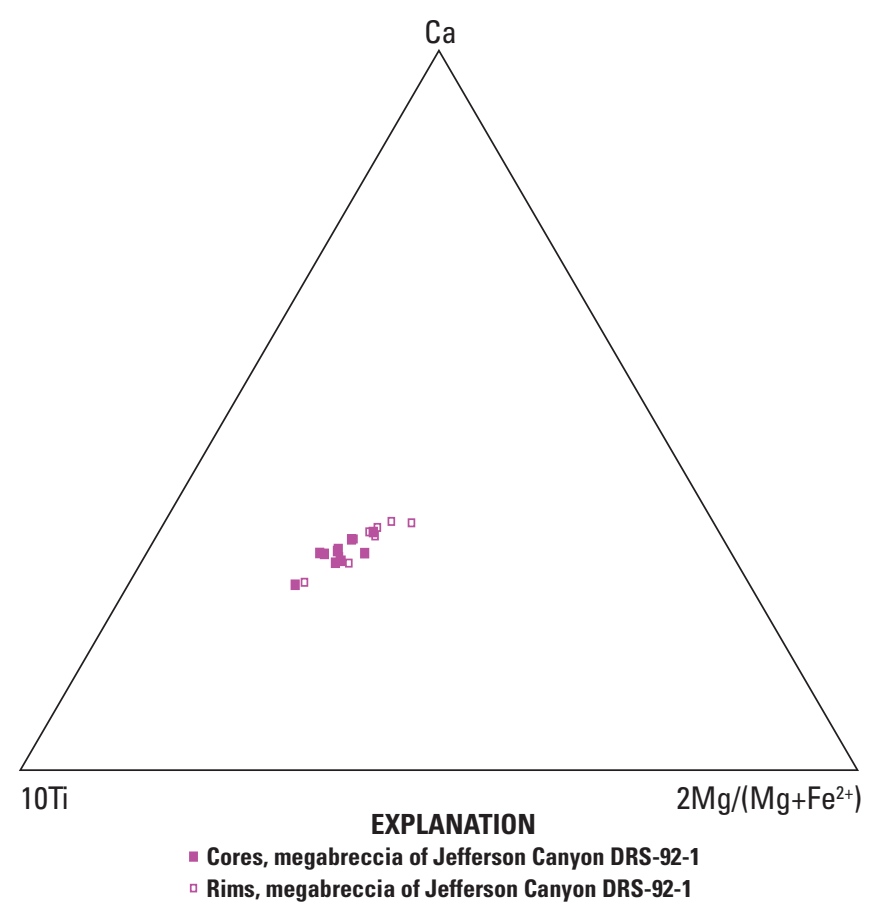

Figure 4. Ternary diagram of $\mathrm{Ca}-10 \mathrm{Ti}-2 \mathrm{Mg} /\left(\mathrm{Mg}+\mathrm{Fe}^{2+}\right)$ showing relative cation abundances in hornblende of one sample, southern Toquima Range, Nye County, Nevada. (Sample DRS-92-1; unit Tgs of Shawe, 1995)

incorporated as clasts in the younger megabreccia. ${ }^{40} \mathrm{Ar} /{ }^{39} \mathrm{Ar}$ dating of the sample of vitrophyre (DRS-92-1) would clarify these relationships.

\section{Tuff of Corcoran Canyon (Unit Tcc)}

Compositions of biotite were determined for two samples of the tuff of Corcoran Canyon (unit Tcc). Sample DRS-91-59 is from the lower member and sample DRS-91-89 is from the upper member. Biotite compositions form two well-defined clusters (fig. 7); biotite of DRS-91-89 is relatively enriched in $\mathrm{Mg}-\mathrm{Fe}^{2+}+\mathrm{Mn}$, whereas biotite of DRS-91-59 is more enriched in $\mathrm{Al}^{3+}+\mathrm{Fe}^{3+}+\mathrm{Ti}$. The upper member sample (DRS-91-89) seems to have crystallized from a more mafic magma than the sample from the lower member (DRS-91-59), which suggests that the earlier eruption may have come from the upper, more evolved part of a compositionally stratified magma reservoir, whereas the later eruption came from the lower, less evolved part.

Compositions of biotite phenocrysts in the tuff of Corcoran Canyon (TcC) are similar to those in the tuffs of Mount Jefferson (Tmj), and of Ryecroft Canyon (Trc), although compositions of biotite phenocrysts in all three units suggest compositional variation within their source reservoirs. Inferred magma composition variation may indicate compositionally stratified magma reservoirs or periodic eruptions from differently evolved magmas, or both. Overall biotite compositional similarity among the three units suggests that they had similar petrogenetic histories. 


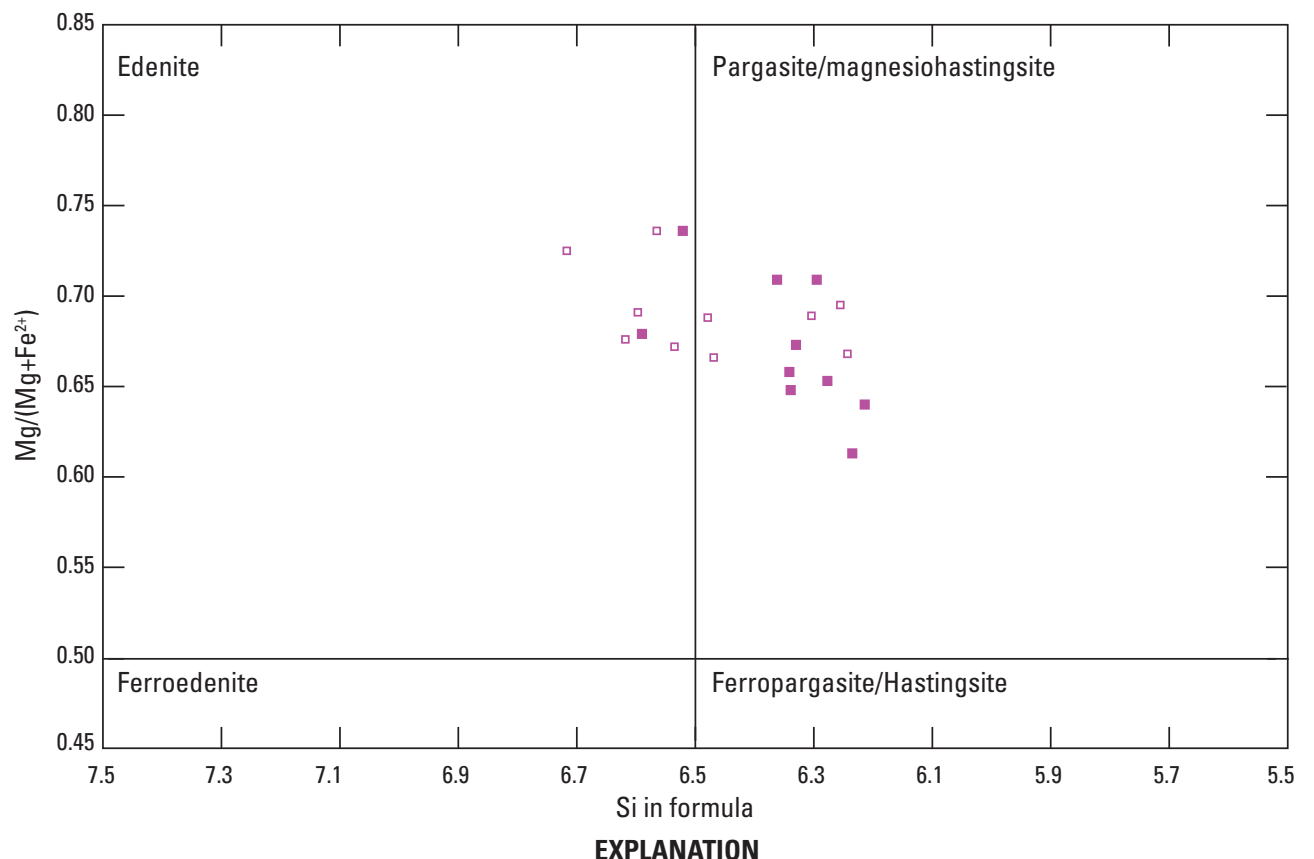

- Cores, megabreccia of Jefferson Canyon DRS-92-1

- Rims, megabreccia of Jefferson Canyon DRS-92-1

Figure 5. Diagram showing relative cation abundances of Si and $\mathrm{Mg} /\left(\mathrm{Mg}+\mathrm{Fe}^{2+}\right)$ in hornblende of one sample, southern Toquima Range, Nye County, Nevada. (Sample DRS-92-1; unit Tgs of Shawe, 1995)

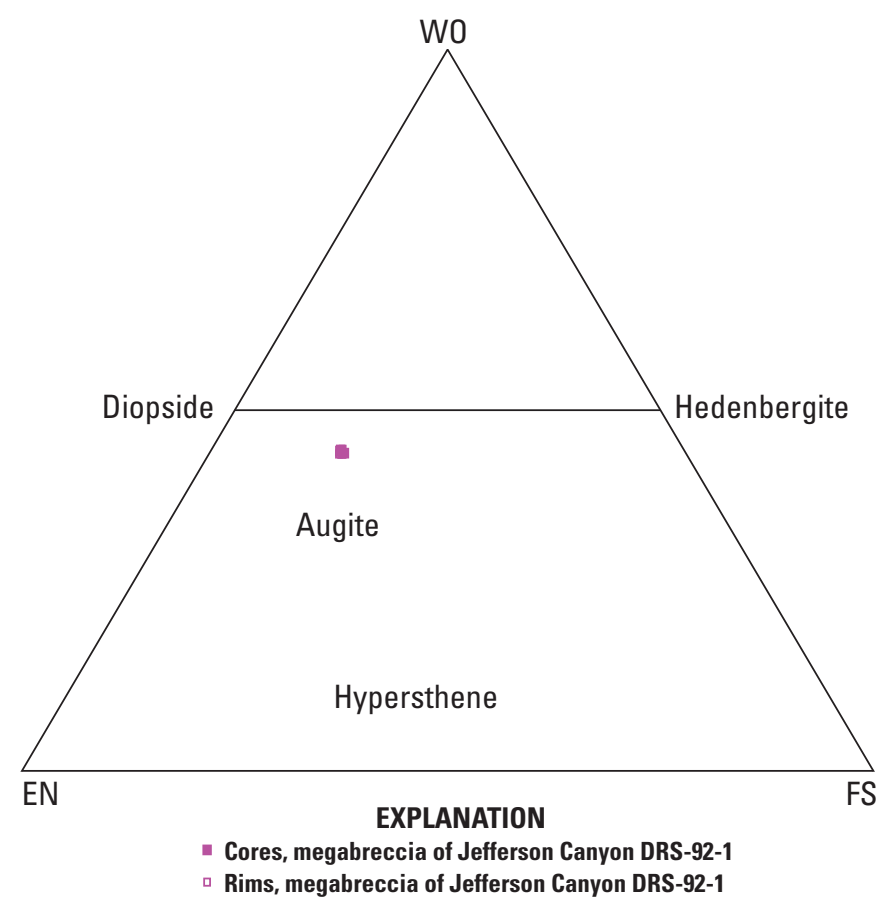

Figure 6. Ternary diagram showing proportions of wollastonite, enstatite, and ferrosilite in clinopyroxene of one sample, southern Toquima Range, Nye County, Nevada; EN, enstatite; FS, ferrosilite; W0, wollastonite. (Sample DRS-92-1; unit Tgc of Shawe, 1995)

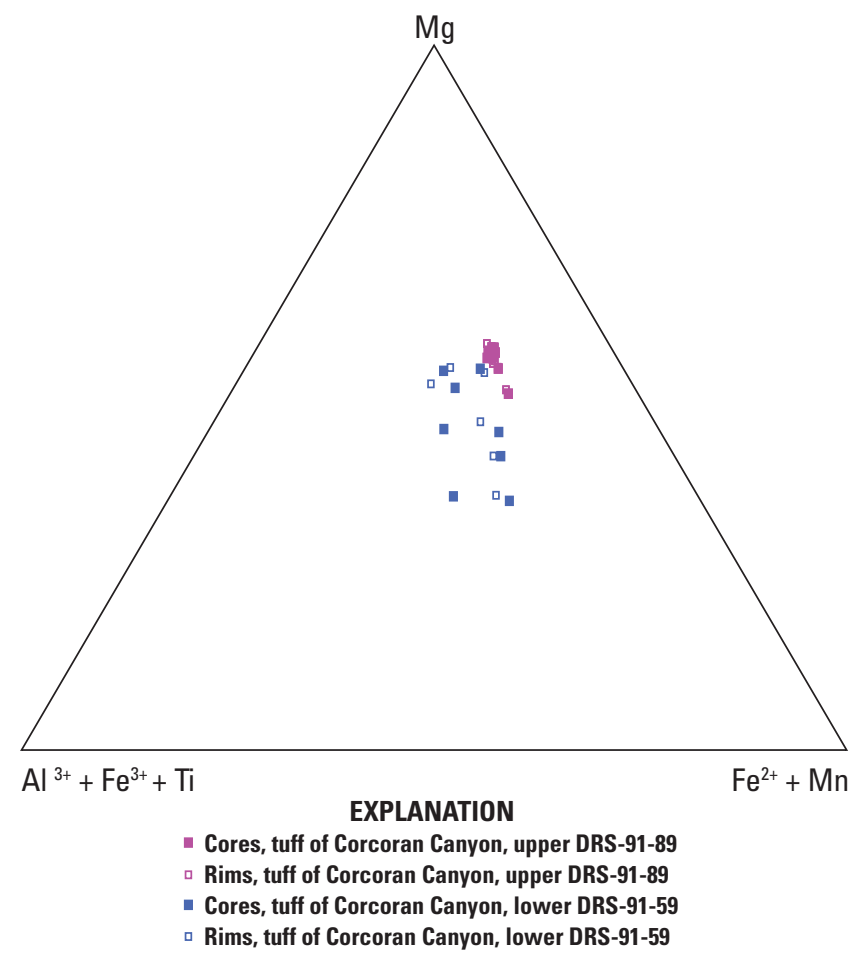

Figure 7. Ternary diagram of $\mathrm{Mg}-\mathrm{Al}^{3+}+\mathrm{Fe}^{3+}+\mathrm{Ti}-\mathrm{Fe}^{2+}+\mathrm{Mn}$ showing relative cation abundances in biotite of two samples, southern Toquima Range, Nye County, Nevada. (Samples DRS-91-89 and DRS-91-59; unit Tcc of Shawe, Hardyman, and Byers, 2000) 
No composition data were obtained for hornblende or pyroxene in the tuff of Corcoran Canyon (Tcc) because no unaltered phenocrysts could be identified. Similarly, no analyses of feldspar phenocrysts in samples DRS-91-59 and DRS-91-89 from the tuff of Corcoran Canyon were obtained.

\section{Tuff of Ryecroft Canyon (Unit Trc)}

We determined compositions of biotite and amphibole in samples DRS-91-19, DRS-91-21, and DRS-91-24 of the tuff of Ryecroft Canyon (Trc). Sample DRS-91-19 was collected near the base of exposed tuff of Ryecroft Canyon; samples DRS-91-21 and DRS-91-24 came from relatively higher stratigraphic positions, possibly less than about $90 \mathrm{~m}$ higher; disparate compaction foliation attitudes (suggestive of fault disruption) in the sampled area precluded more accurate assessment of relative stratigraphic position.

Compositions of biotite in samples DRS-91-21 and DRS-91-24 (fig. 8) form nearly coincident well-defined trends, whereas those in sample DRS-91-19 (fig. 8) cluster near the $\mathrm{Fe}^{2+}+\mathrm{Mn}$-rich (hence more silicic) end of the DRS-91-21 and DRS-91-24 compositional arrays. Apparently, prior to eruption the source magma became compositionally stratified such that the initial eruption may have been from the upper

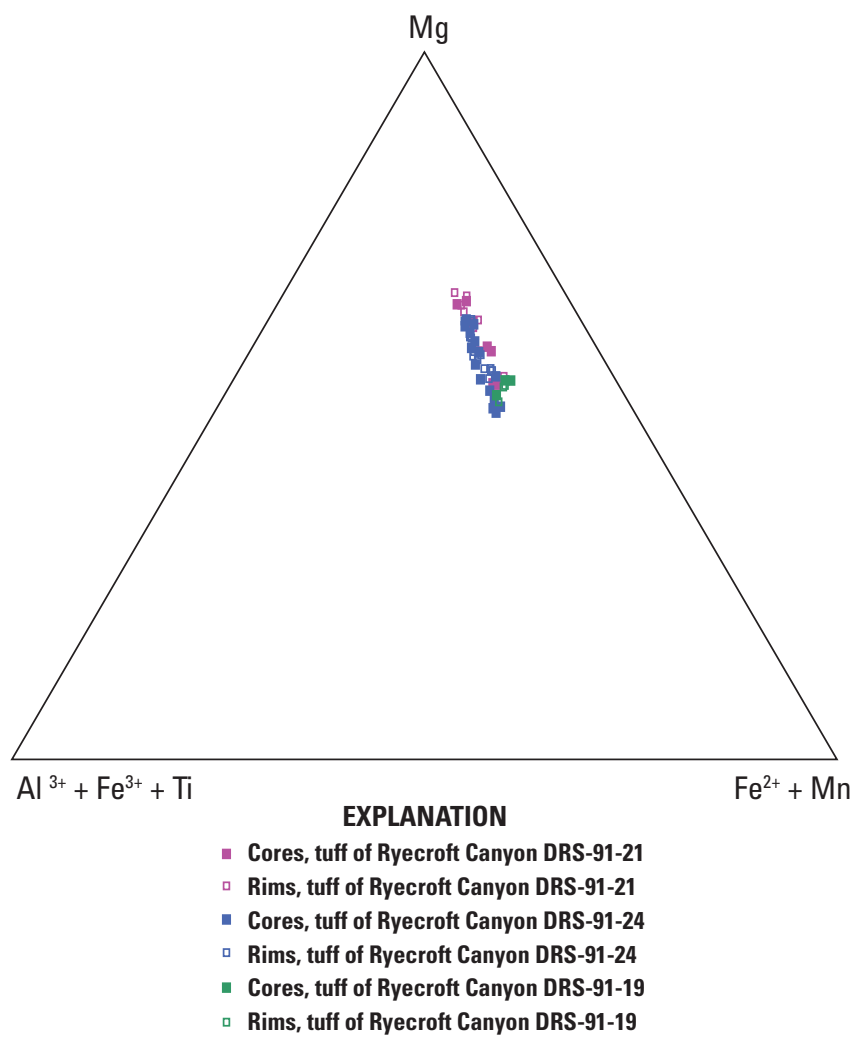

Figure 8. Ternary diagram of $\mathrm{Mg}-\mathrm{Al}^{3+}+\mathrm{Fe}^{3+}+\mathrm{Ti}-\mathrm{Fe}^{2+}+\mathrm{Mn}$ showing relative cation abundances in biotite of three samples, southern Toquima Range, Nye County, Nevada. (Samples DRS-91-21, DRS-91-24, and DRS-91-19; unit Trc of Shawe, Hardyman, and Byers, 2000) part of a zoned reservoir and later eruption may have come from lower in the reservoir. Compositions of biotite in samples from the tuff of Ryecroft Canyon are also nearly coincident with those of biotite in the tuff of Mount Jefferson (Tmj), which suggests their possible cogenesis. However, compositions of biotite in the tuff of Ryecroft Canyon are less Fe-Mn rich and more $\mathrm{Mg}$ rich, which suggests that magma represented by the slightly younger tuff of Mount Jefferson was less evolved than magma represented by the tuff of Ryecroft Canyon.

Compositions of amphiboles (fig. 9) in samples DRS-91-19, DRS-91-21, and DRS-91-24 of the tuff of Ryecroft Canyon (TrC) form a linear trend that extends from a separate cluster of DRS-91-19 analyses with relatively $\mathrm{Ca}-$ to $\mathrm{Mg}$-Fe-rich compositions (mostly edenite) to a broad cluster of DRS-91-21 and DRS-91-24 compositions (mostly pargasite/magnesiohastingsite, fig. 10) that are relatively enriched in Ti. These compositional variations suggest that sample DRS-91-19, from near the base of the Ryecroft Canyon, crystallized from a less evolved magma than did samples DRS-91-21 and DRS-91-24 from several hundred meters higher in the formation. The variations suggest eruption of discrete magma batches, either from a zoned magma reservoir or from distinct reservoirs having different compositions

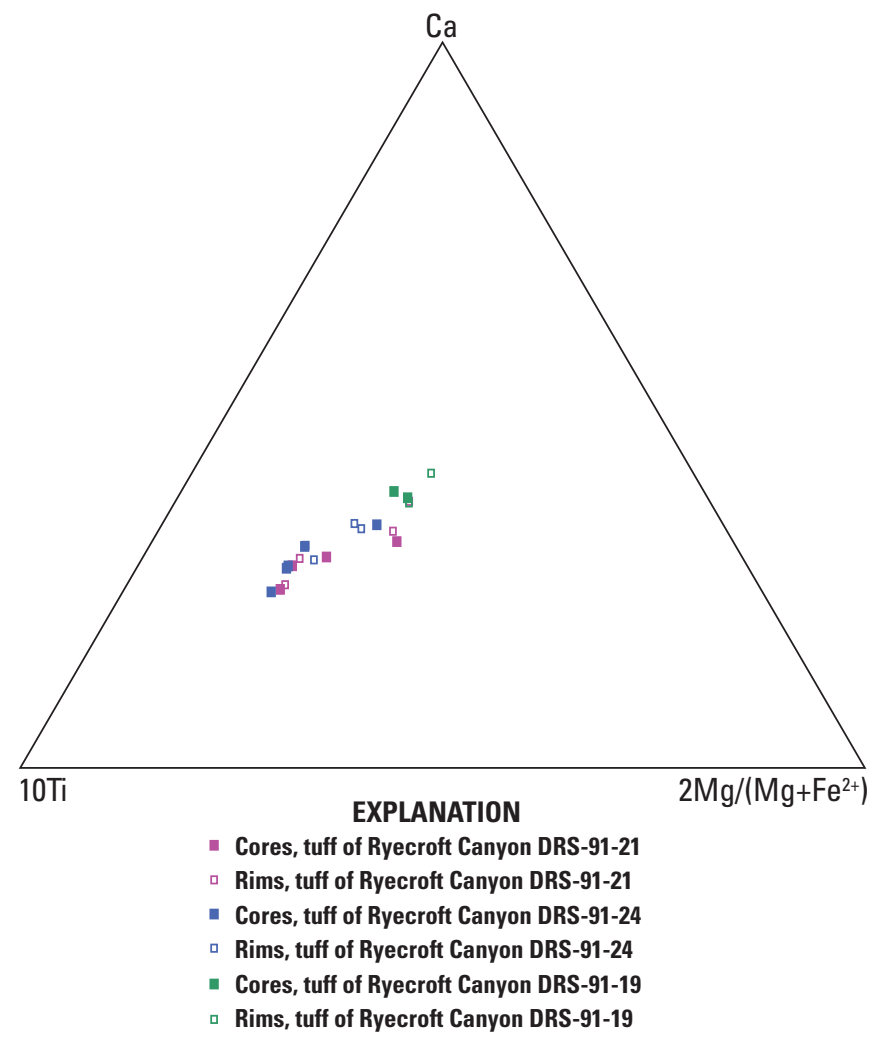

Figure 9. Ternary diagram of $\mathrm{Ca}-10 \mathrm{Ti}-2 \mathrm{Mg} /\left(\mathrm{Mg}+\mathrm{Fe}^{2+}\right)$ showing relative cation abundances in hornblende of three samples, southern Toquima Range, Nye County, Nevada. (Samples DRS-91-21, DRS-91-24, and DRS-91-19; unit Trc of Shawe, 1999b) 


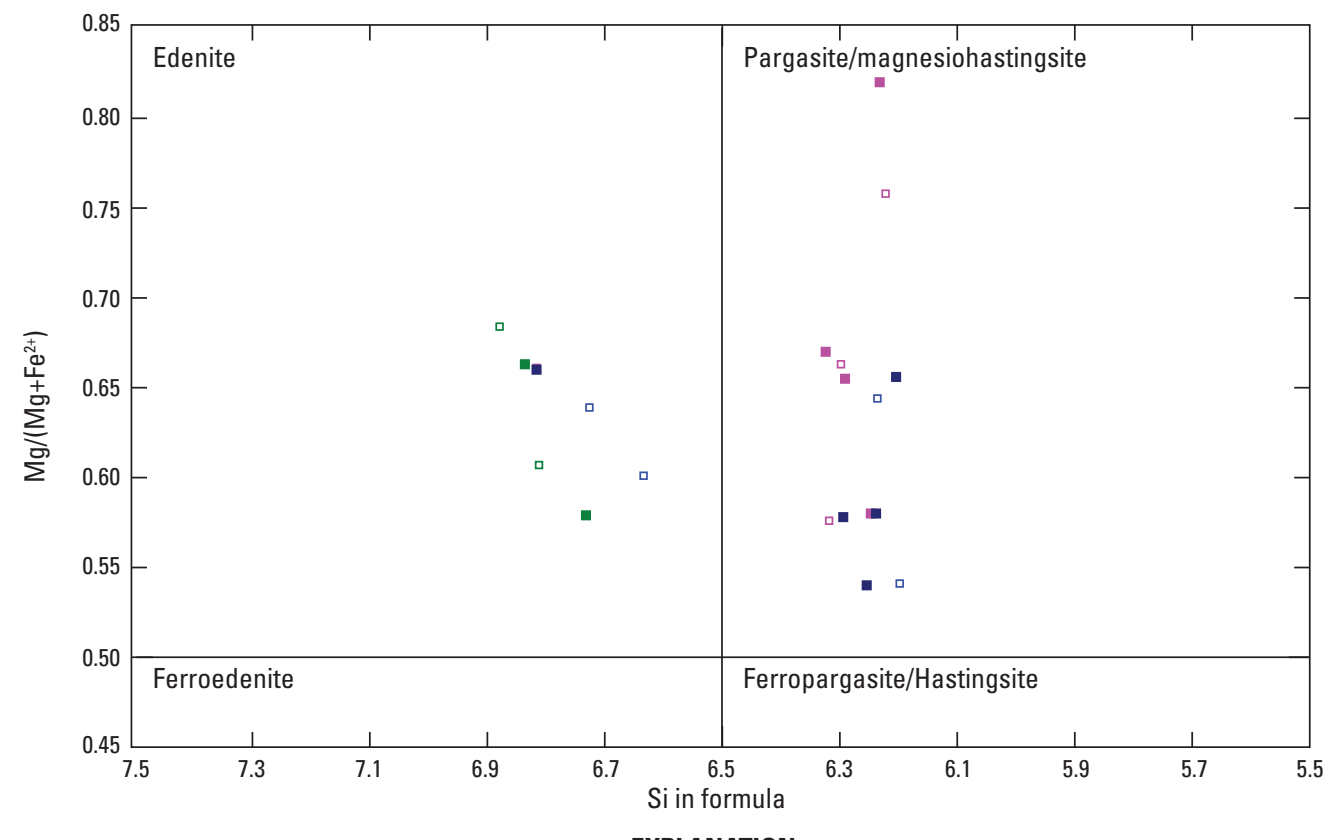

$\begin{array}{ll}- \text { Cores, tuff of Ryecroft Canyon DRS-91-21 } & \text { - Rims, tuff of Ryecroft Canyon DRS-91-24 } \\ \text { - Rims, tuff of Ryecroft Canyon DRS-91-21 } & \text { - Cores, tuff of Ryecroft Canyon DRS-91-19 } \\ \text { - Cores, tuff of Ryecroft Canyon DRS-91-24 } & - \text { Rims, tuff of Ryecroft Canyon DRS-91-19 }\end{array}$

Figure 10. Diagram showing relative cation abundances of $\mathrm{Si}$ and $\mathrm{Mg} /\left(\mathrm{Mg}+\mathrm{Fe}^{2+}\right)$ in hornblende of three samples, southern Toquima Range, Nye County, Nevada. (Samples DRS-91-21, DRS-91-24, and DRS-91-19; unit Trc of Shawe, 1999b)

We determined compositions of feldspar phenocrysts in samples DRS-91-21 and DRS-91-24 of the tuff of Ryecroft Canyon Trc (fig. 11). Sanidine compositions are similar in the two samples and are slightly enriched in albite in sample DRS-91-24 relative to sample DRS-91-21. Plagioclase compositions in the two samples are similar, except that some plagioclase in sample DRS-91-21 is enriched in CaO. Also, compositions of plagioclase in the tuff of Mount Jefferson (Tmj) (see later discussion of fig. 20) and tuff of Ryecroft Canyon (fig. 11) are indistinguishable, and sanidine compositions are similar, which suggests similar petrogenetic histories for magma represented by the two tuffs.

\section{Tuff of Mount Jefferson (Unit Tmj)}

The tuff of Mount Jefferson (Tmj) provided the largest set of samples for which phenocryst compositions were determined, including samples from the unit we mapped as tuff of Mount Jefferson (3 samples analyzed) and the unit mapped by Boden $(1986,1992)$ as tuff of Trail Canyon (5 samples analyzed). Whole-rock chemistry and phenocryst index (PI) data for the tuff of Mount Jefferson (unit (Tmj) of Shawe, 1999b), do not vary systematically relative to stratigraphic position. Nonsystematic data of this sort are consistent with derivation of successive ash flow eruptions by nonsystematically tapping various levels within a vertically zoned magma reservoir, or by top-down eruption from a

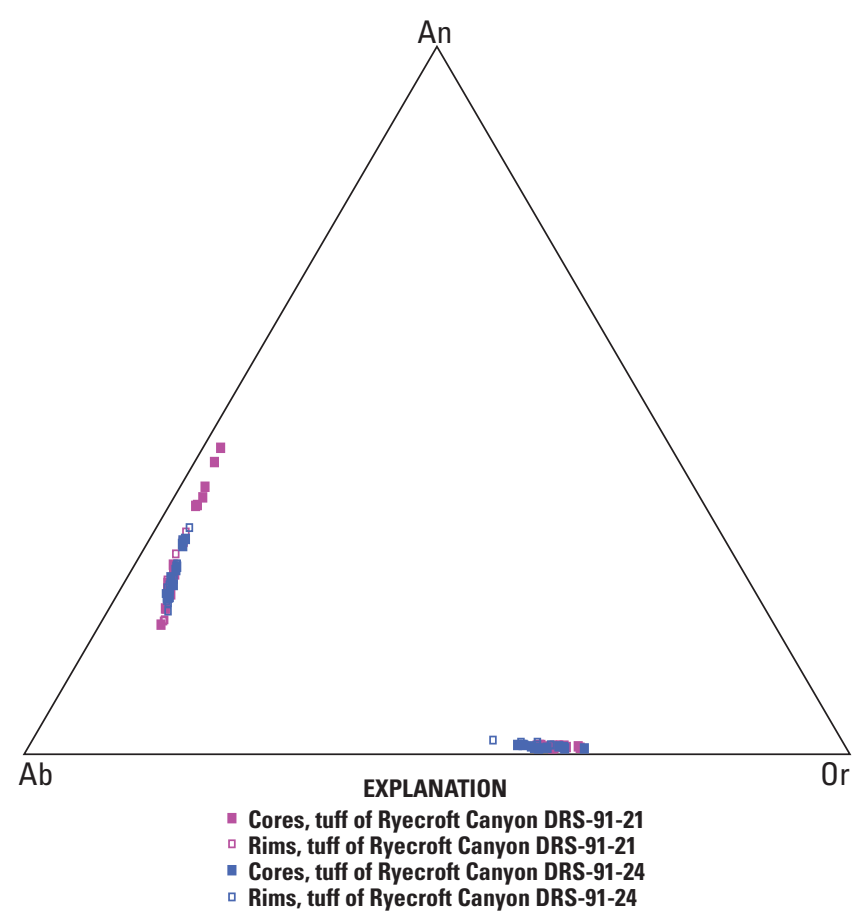

Figure 11. Ternary diagram showing molecular end-member proportions of albite, anorthite, and orthoclase feldspars in two samples, southern Toquima Range, Nye County, Nevada. (Samples DRS-91-21 and DRS-91-24; unit Trc of Shawe, 1999b; Ab, albite, An, anorthite; Or, orthoclase) 
nonsystematically zoned reservoir. The eight analyzed samples from the tuff of Mount Jefferson were collected from the upper $700 \mathrm{~m}$ of the (intracaldera) principal member of the formation. Because this member is probably more than 2,000 m thick (Shawe, 1999b), these analyses depict only the latest intervals of its petrogenetic history.

Estimates of relative stratigraphic position suggest that samples (DRS-85-44, DRS-85-203, and DRS-85-204) collected on the west side of the Soldier Spring fault are likely from the middle part of the principal member. Samples (DRS-92-20, DRS-85-199, DRS-85-197, DRS-91-168, and DRS-91-169), collected on the east side of the Soldier Spring fault, are from the upper part of the principal member.

We determined the compositions of biotite in eight samples (fig. 12-DRS-85-44, DRS-85-203, DRS-85-204; fig. 13-DRS-92-20, DRS-85-199, DRS-85-197, and fig. 14DRS-91-168, DRS-91-169). Biotite in the two lowest samples (DRS-85-44 and DRS-85-203, fig. 12) has compositions that cluster in a small field with somewhat more $\mathrm{Mg}$ than $\mathrm{Fe}^{2+}+\mathrm{Mn}$. Biotite from the stratigraphically next higher sample (DRS-85-204, fig. 12) has similar compositions, except that one analysis indicates slightly less $\mathrm{Mg}$ than $\mathrm{Fe}^{2+}+\mathrm{Mn}$. Samples apparently stratigraphically higher (fig. 13-DRS-92-20, DRS-85-199, and DRS-85-197; and fig. 14-DRS-91-168, and DRS-91-169) have compositions that define two fields, one similar to those of the lower three samples, and a second that indicates compositions with slightly less Mg than

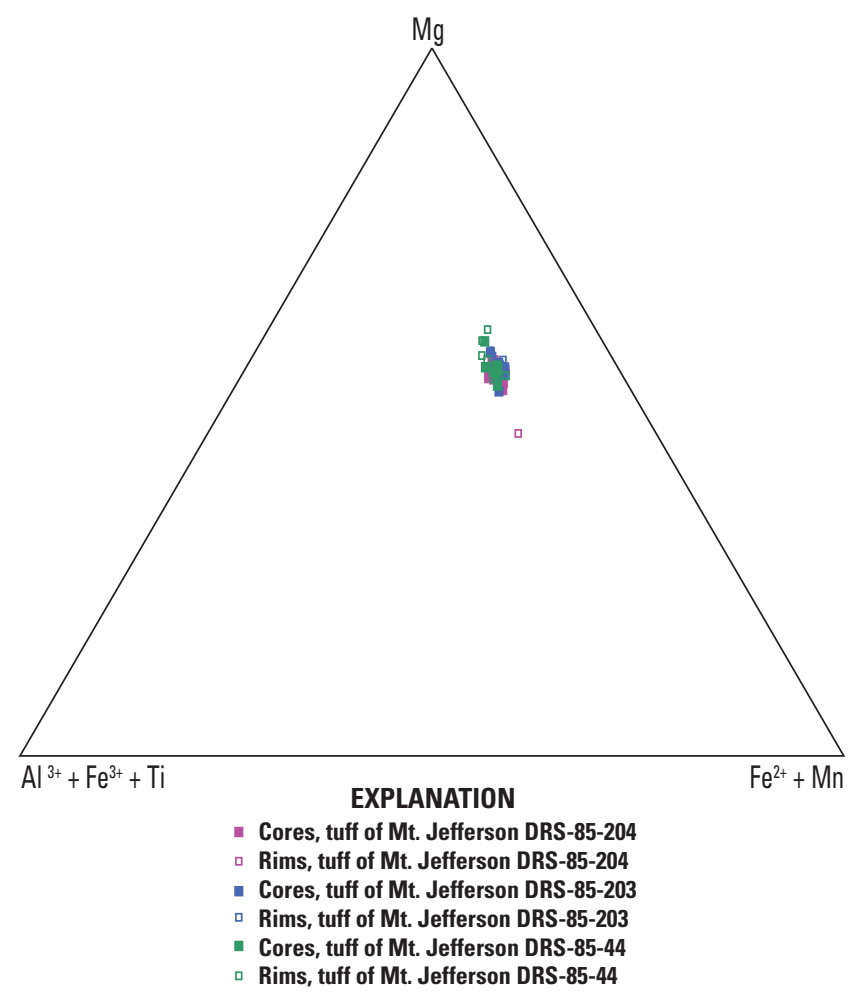

Figure 12. Ternary diagram of $\mathrm{Mg}-\mathrm{Al}^{3+}+\mathrm{Fe}^{3+}+\mathrm{Ti}-\mathrm{Fe}^{2+}+\mathrm{Mn}$ showing relative cation abundances in biotite of three samples, southern Toquima Range, Nevada. (Samples DRS-85-204, DRS-85-203, and DRS-85-44; unit Tmi of Shawe, 1995)

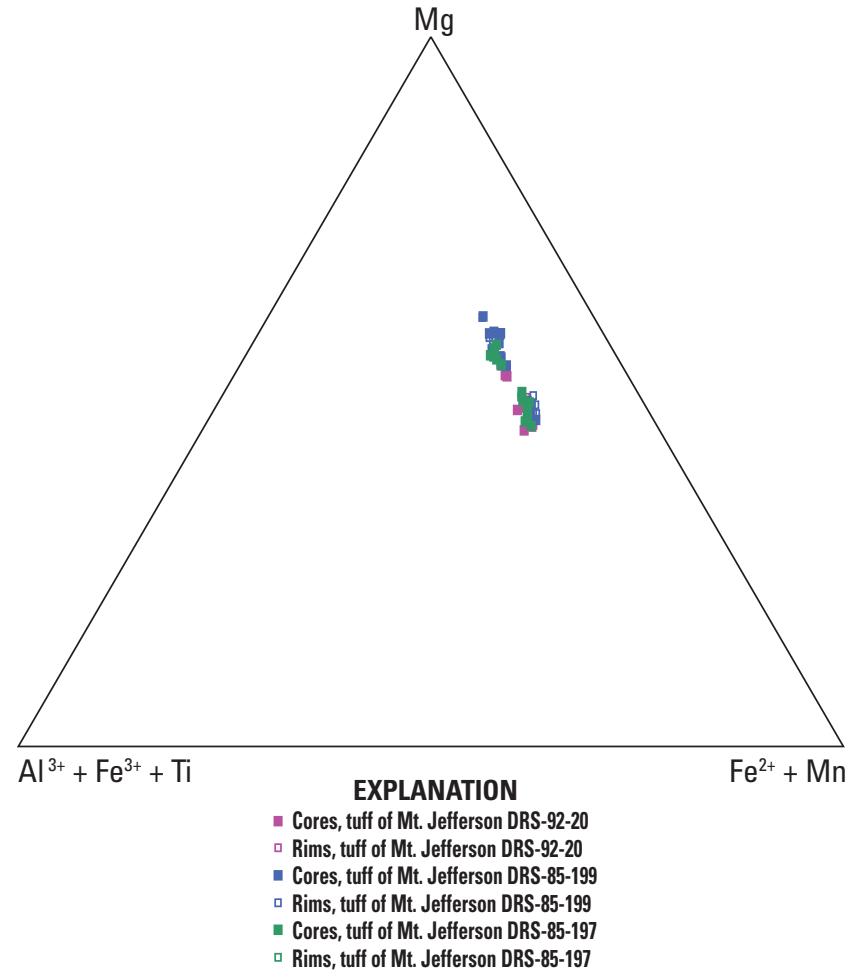

Figure 13. Ternary diagram of $\mathrm{Mg}-\mathrm{Al}^{3+}+\mathrm{Fe}^{3+}+\mathrm{Ti}-\mathrm{Fe}^{2+}+\mathrm{Mn}$ showing relative cation abundances in biotite of three samples, southern Toquima Range, Nye County, Nevada. (Samples DRS-92-20, DRS-85-199, and DRS-85-197; unit Tmj of Shawe, 1995)

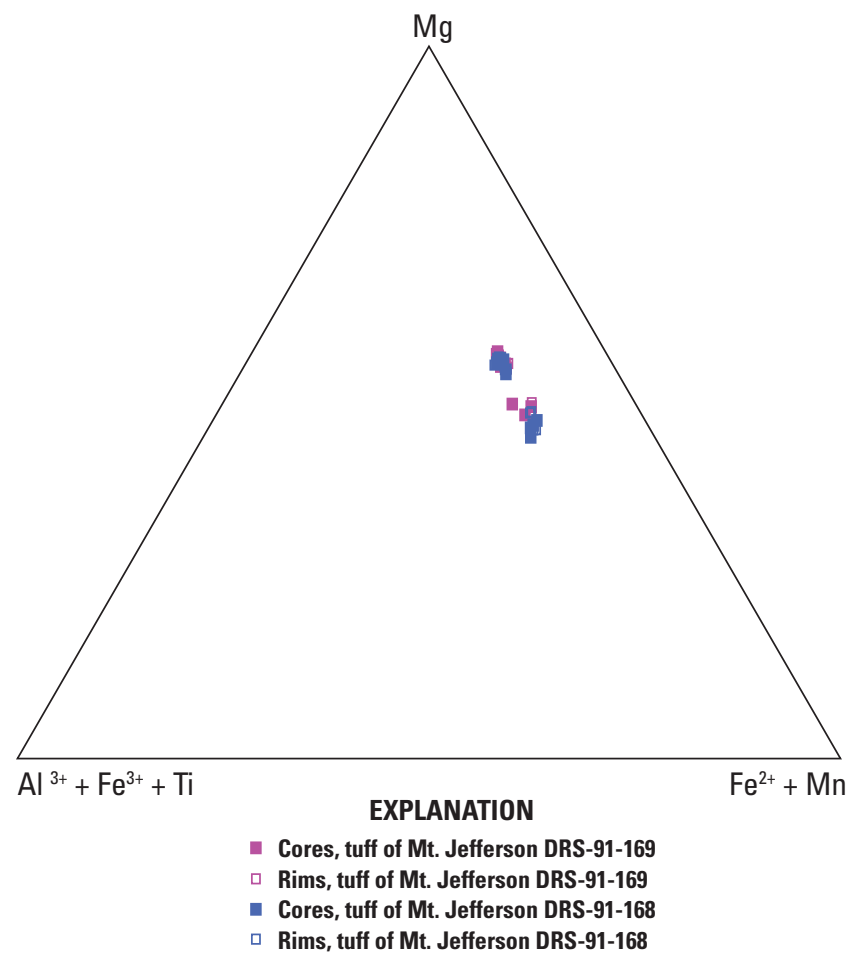

Figure 14. Ternary diagram of $\mathrm{Mg}-\mathrm{Al}^{3+}+\mathrm{Fe}^{3+}+\mathrm{Ti}-\mathrm{Fe}^{2+}+\mathrm{Mn}$ showing relative cation abundances in biotite of two samples, southern Toquima Range, Nye County, Nevada. (Samples DRS-91169 and DRS-91-168; unit Tmj of Shawe, 1995) 
$\mathrm{Fe}^{2+}+\mathrm{Mn}$. The biotite data for all eight samples suggest that initial eruptions were derived from a layer relatively enriched in $\mathrm{Mg}$ - in a normally zoned two-layer reservoir and a higher, more evolved, layer relatively enriched in Fe; subsequent eruptions may represent a mixture of both layers.

Compositions of amphibole phenocrysts in seven samples of the principal member of the tuff of Mount Jefferson (Tmj) define two trends (fig. 15-DRS-85-44, DRS-85-203, DRS-85-204, DRS-92-20, DRS-85-199, DRS-85-197, and DRS-91-169). Two samples, DRS-85-199 and DRS-85-197 (fig. 16) from near the top of the formation, characterize the two trends most distinctly. Compositions of amphibole phenocrysts in sample DRS-92-20 (figs. 16, 17) are coincident with only the more Ca-rich of the two trends. The two compositional groups most diagnostic of the tuff of Mount Jefferson (the majority of analyses, fig. 15) suggest that successive eruptions tapped both layers of a compositionally zoned, two-layer magma reservoir. Linear trends define subparallel arrays of amphibole composition - each trend is likely related to a particular layer in a two-layer magma reservoir - which suggest successive amphibole crystallization from either $\mathrm{Ca}$ - and $\mathrm{Mg}$-rich magma, or crystallization from more fractionated, Ti-rich (more evolved) magma. Compositions of these amphiboles vary widely within

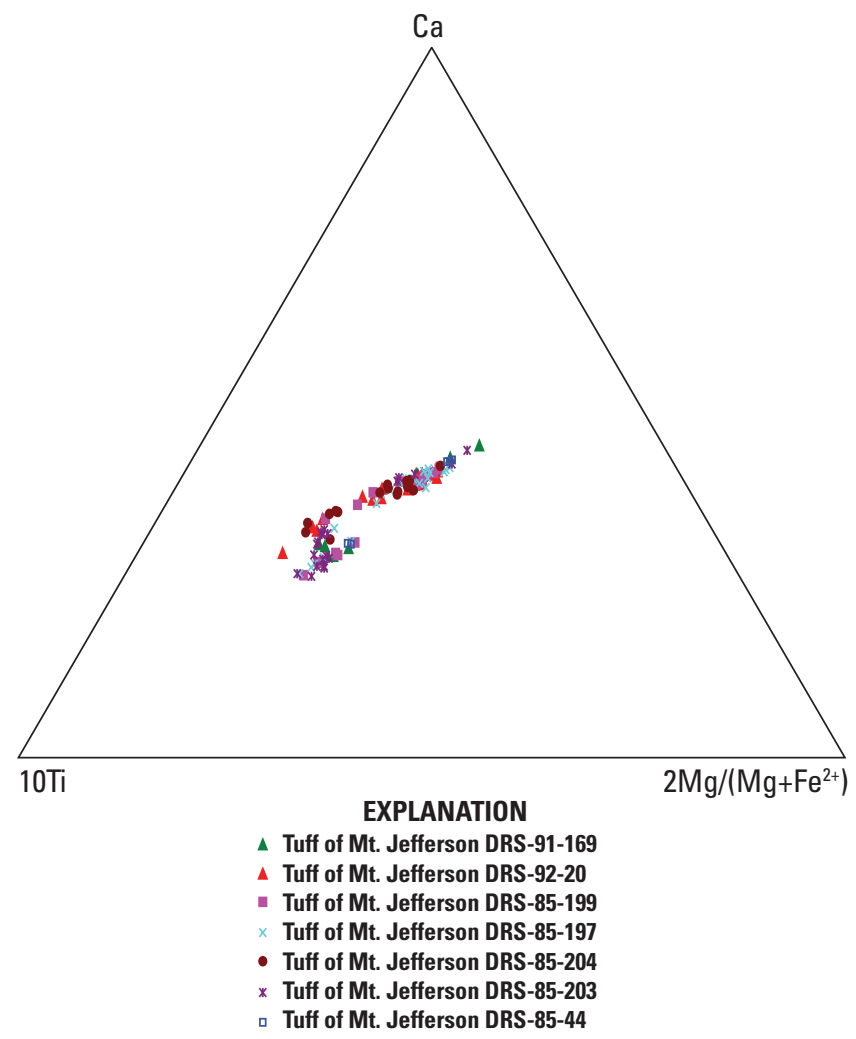

Figure 15. Ternary diagram of $\mathrm{Ca}-10 \mathrm{Ti}-2 \mathrm{Mg} /\left(\mathrm{Mg}+\mathrm{Fe}^{2+}\right)$ showing relative cation abundances in hornblende of seven samples, southern Toquima Range, Nye County, Nevada. (Samples DRS-91-169, DRS-92-20, DRS-85-199, DRS-85-197, DRS-85-204, DRS-85-203, and DRS-85-44; unit Tmj of Shawe, 1995)

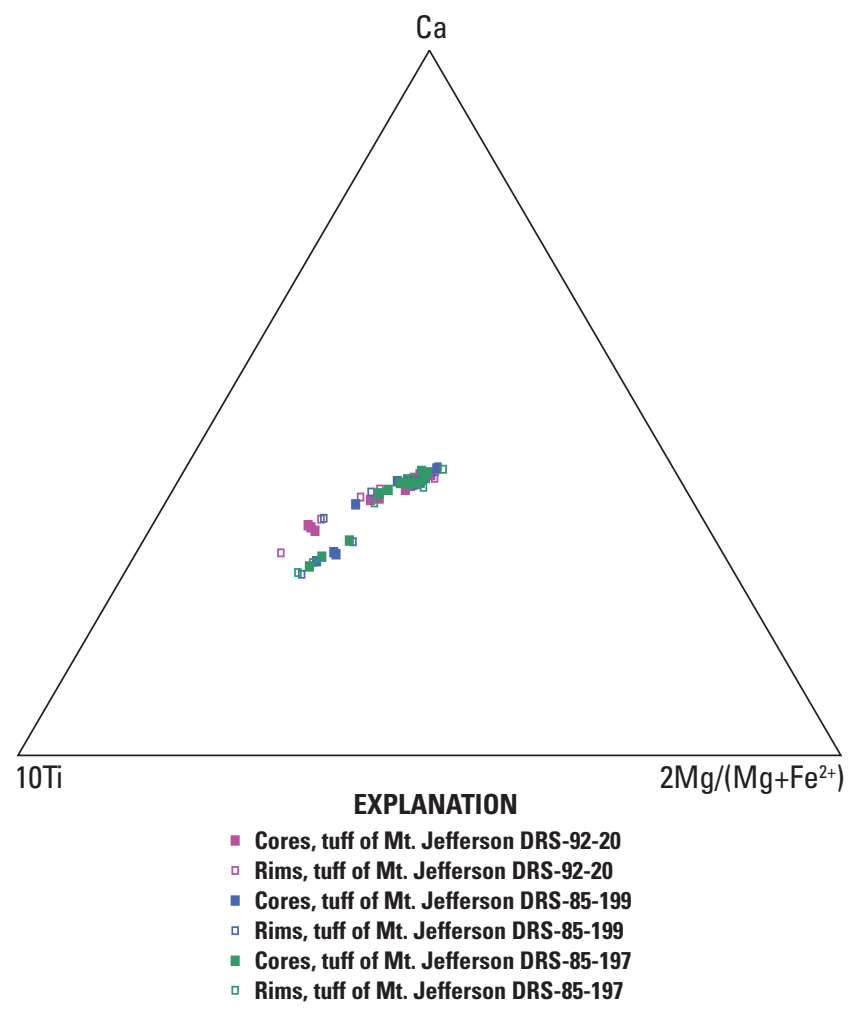

Figure 16. Ternary diagram of $\mathrm{Ca}-10 \mathrm{Ti}-2 \mathrm{Mg} /\left(\mathrm{Mg}+\mathrm{Fe}^{2+}\right)$ showing relative cation abundances in hornblende of three samples, southern Toquima Range, Nye County, Nevada. (Samples DRS-92-20, DRS-85-199, and DRS-85-197; unit Tmj of Shawe, 1995)

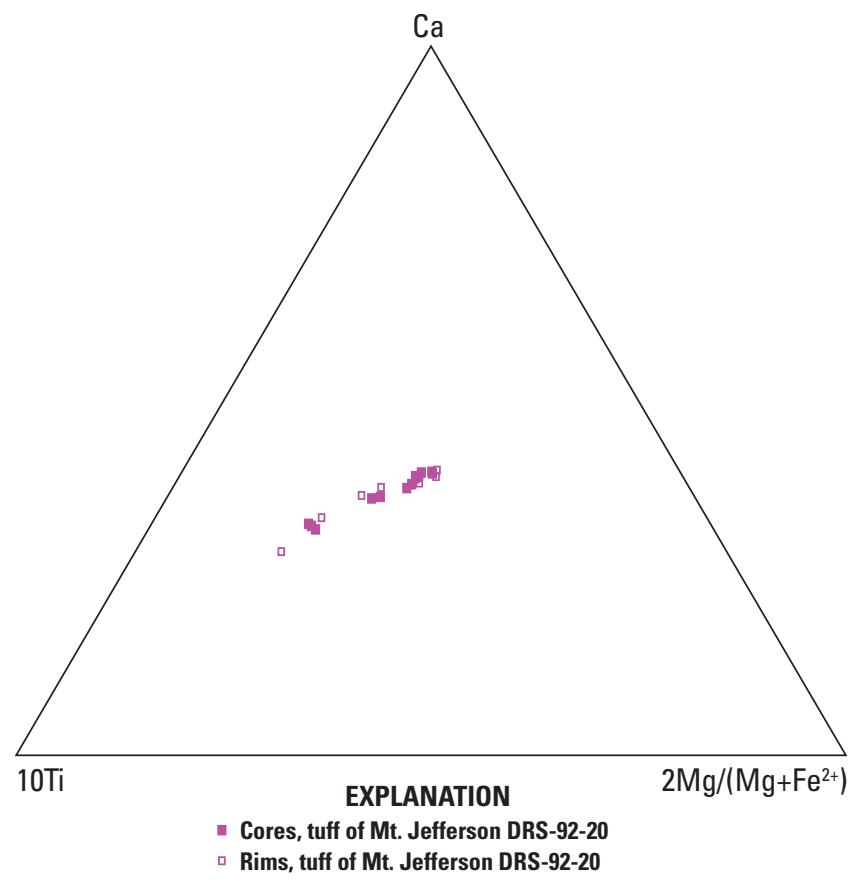

Figure 17. Ternary diagram of $\mathrm{Ca}-10 \mathrm{Ti}-2 \mathrm{Mg} /\left(\mathrm{Mg}+\mathrm{Fe}^{2+}\right)$ showing relative cation abundances in hornblende of one sample, southern Toquima Range, Nevada. (Sample DRS-92-20; unit Tmj of Shawe, 1995) 
the edenite and pargasite/magnesiohastingsite fields (fig. 18). The well-defined compositional trend of amphibole from sample DRS-92-20 (fig. 18) suggests progressive top-down eruption from a vertically zoned magma reservoir (more evolved compositions near its top and less evolved compositions at depth); the lack of amphibole compositional discontinuities suggests eruption from a single, continuously zoned reservoir. Compositions of amphibole in other samples appear to indicate mixing of lower and upper magma composition layers during eruption of the associated magmas.

Pyroxene compositions (fig. 19) in six analyzed samples of tuff of Mount Jefferson (Tmj) (DRS-85-44, DRS-85-203, DRS-92-20, DRS-85-199, DRS-85-197, and DRS-91-169) define a restricted composition range in the augite field. Inasmuch as compositions of biotite and amphibole suggest crystallization from a zoned magma reservoir, the single augite composition field suggests that augite likely crystallized early in only one (presumably the lower, less fractionated) zone of a two-layer magma reservoir.

We determined compositions of feldspar phenocrysts in two samples of the tuff of Mount Jefferson (Tmj) (fig. 20). One sample, DRS-85-44, was collected approximately $700 \mathrm{~m}$ below the top of the tuff, whereas the other sample, DRS-91-168, was collected about $100 \mathrm{~m}$ below its top. Although the composition fields of feldspars from the two samples overlap, sanidine in sample DRS-91-168 is potassium rich relative to sanidine in sample DRS-85-44, and the plagioclase feldspar in sample DRS-91-168 is relatively enriched in albite, whereas sample DRS-85-44 plagioclase is relatively enriched in anorthite.

\section{Isom-Type Ash-Flow Tuff (Unit Ti)}

We determined compositions of phenocrysts in three samples of Isom-type tuffs (Ti); however, compositions of biotite were not determined in any of these samples. Analyses of amphiboles in samples DRS-84-34 and DRS-87-52 (fig. 21) indicate compositional trends strikingly similar to those of the tuff of Mount Jefferson (Tmj) (generally two subparallel trends, as in fig. 12). The two trends suggest derivation from a magma reservoir with two compositional layers. Like amphiboles in the tuff of Mount Jefferson, amphiboles in the Isom-type tuff cluster near the boundary of the edenite and the pargasite/magnesiohastingsite composition fields (fig. 22).

Samples DRS-87-52, DRS-87-59, and DRS-84-34 all contain hypersthene but only DRS-84-34 also contains augite (fig. 23). Sample DRS-87-52 was collected from the upper part of the formation. The stratigraphic positions of sample DRS-87-59 and DRS-84-34, as deduced from sample locations on the geologic map, are from the upper and lower parts, respectively. Compositions of hypersthene in samples DRS-87-52 and DRS-87-59 (from the upper part of the formation) are similar, whereas hypersthene compositions in sample DRS-84-34 are more enriched in enstatite (more mafic)

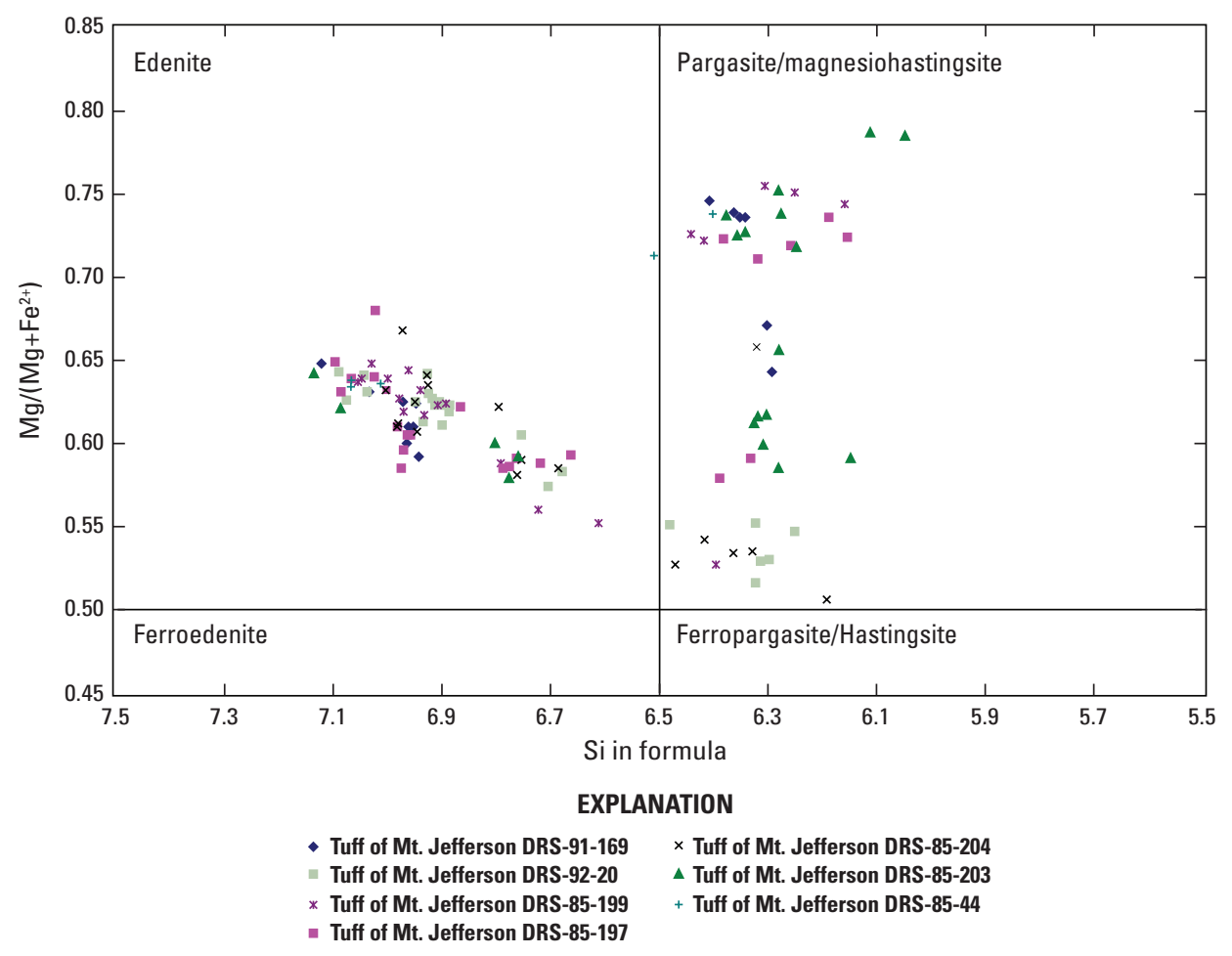

Figure 18. Diagram showing relative cation abundances of $\mathrm{Si}$ and $\mathrm{Mg} /\left(\mathrm{Mg}+\mathrm{Fe}^{2+}\right)$ in hornblende of seven samples, southern Toquima Range, Nye County, Nevada. (Samples DRS-91-169, DRS-92-20, DRS-85-199, DRS-85-197, DRS-85-204, DRS-85-203, and DRS-85-44; unit Tmj of Shawe, 1995) 


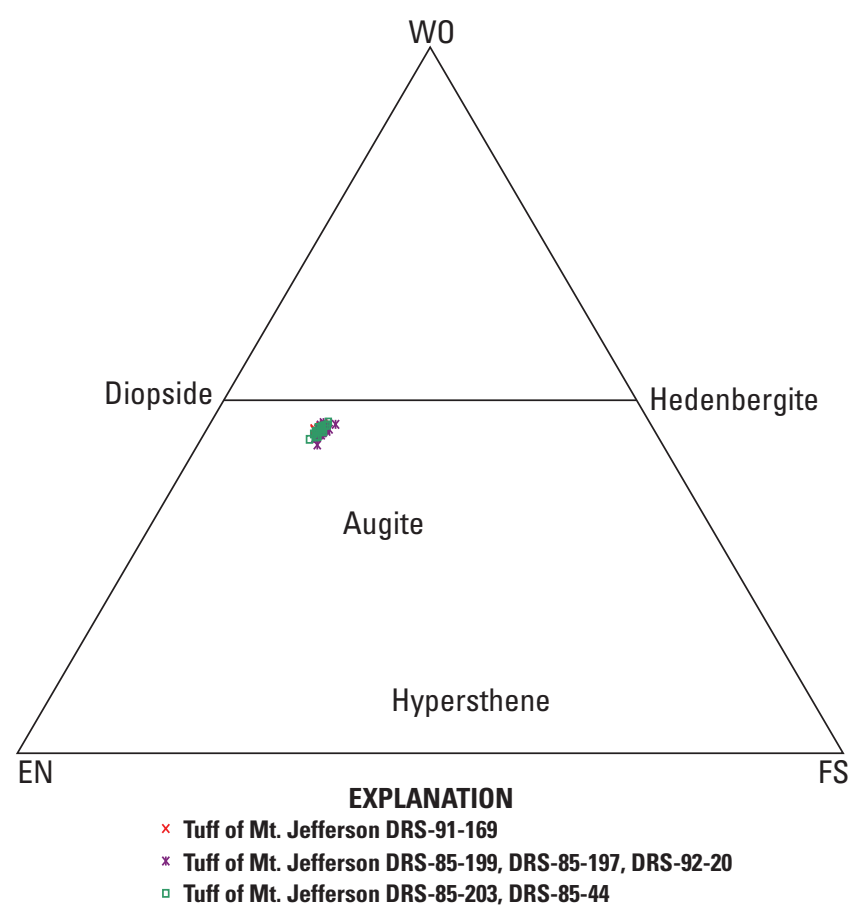

Figure 19. Ternary diagram showing proportions of wollastonite, enstatite, and ferrosilite clinopyroxene in six samples, southern Toquima Range, Nye County, Nevada. (Samples DRS-91-169, DRS-85-199, DRS-85-197, DRS-92-20, DRS-85-203, and DRS-85-44; unit Tmj of Shawe, 1995; W0, wollastonite; EN, enstatite; FS, ferrosilite)

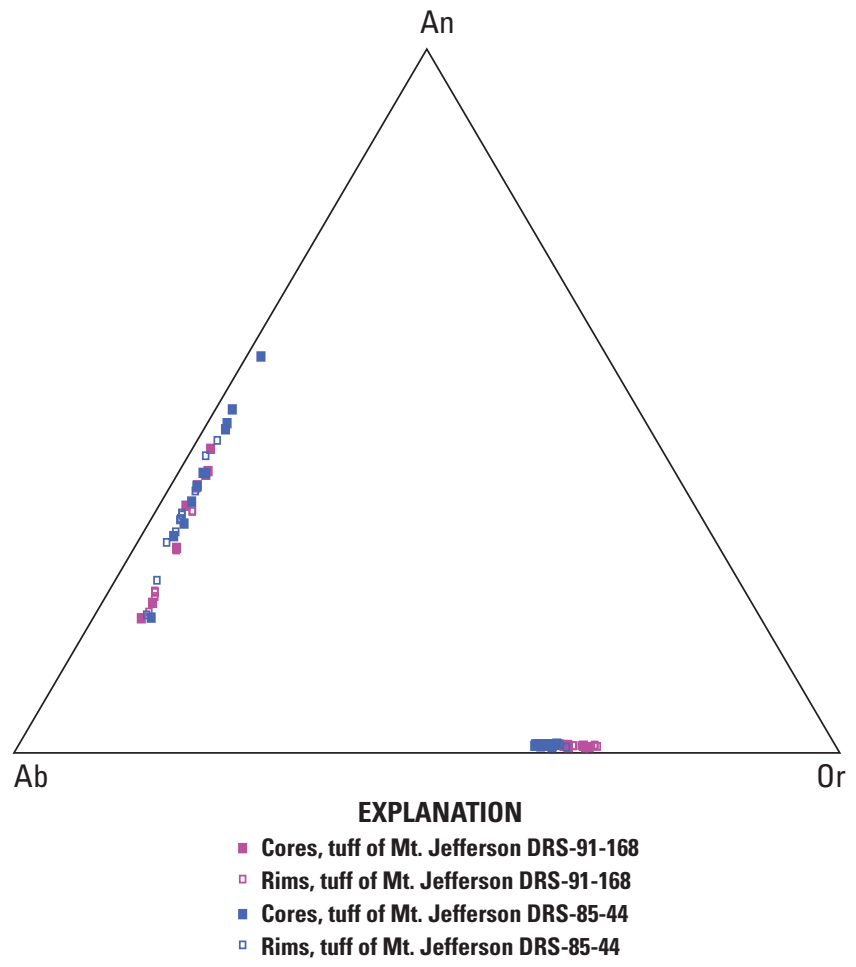

Figure 20. Ternary diagram showing molecular end-member proportions of albite, anorthite, and orthoclase feldspars in two samples, southern Toquima Range, Nye County, Nevada. (Samples DRS-91-168, and DRS-85-44; unit Tmj of Shawe, 1995; Ab, albite; An, anorthite; Or, orthoclase) than are the other two samples. The presence of abundant hypersthene in the Isom-type ash-flow tuff (Ti) and ferrosilitemolecule-enriched augite preclude an affinity with the tuff of Mount Jefferson (Tmj).

Plagioclase feldspar in sample DRS-87-52 is relatively enriched in anorthite, whereas that in sample DRS-84-34 is enriched in albite (fig. 24), which suggests that the tuff was erupted top down from a normally zoned reservoir. Sanidine phenocrysts in Isom-type tuff samples have generally overlapping, indistinguishable compositions.

Most compositions of phenocrysts in Isom-type tuff samples are dissimilar to those in the volcanic rocks erupted from the southern Toquima Range, which confirms derivation of Isom-type ash-flow tuffs from outside the area.

\section{Bates Mountain Tuff (Part of Unit Ty)}

Three ash-flow tuff units grouped in the unit designated on plate 1 as unit Ty are the Bates Mountain Tuff, the tuff of Clipper Gap, and the tuff of Pipe Organ Spring, all younger than the Isom-type ash-flow tuff (see earlier section, Bates Mountain Tuff, Tuff of Clipper Gap, and Tuff of Pipe Organ Spring, that describes these units). We determined compositions of phenocrysts in three samples (DRS-91-3, DRS-91-6, and DRS-91-25) of the Bates Mountain Tuff, the oldest of these three tuffs. Relative stratigraphic positions of these samples are uncertain, so constraining the petrogenetic history of the Bates

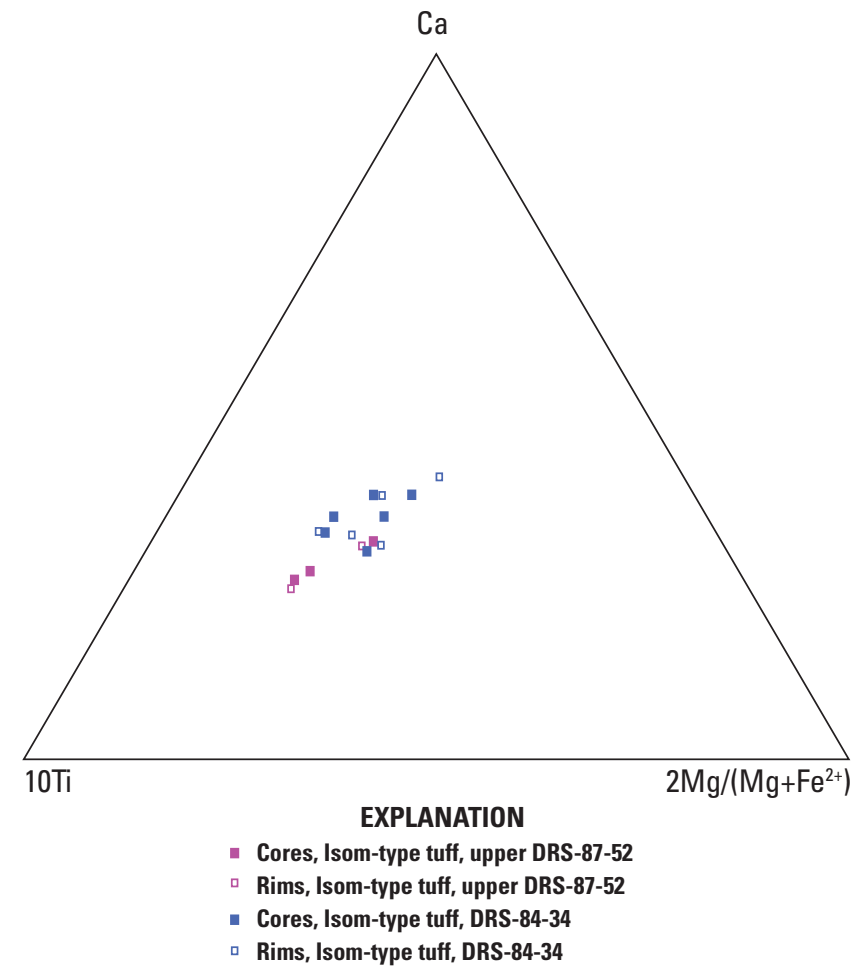

Figure 21. Ternary diagram of $\mathrm{Ca}-10 \mathrm{Ti}-2 \mathrm{Mg} /\left(\mathrm{Mg}+\mathrm{Fe}^{2+}\right)$ showing relative cation abundances in hornblende of two samples southern Toquima Range, Nye County, Nevada. (Samples DRS-87-52 and DRS-84-34; unit Ti of Shawe, 1999b) 


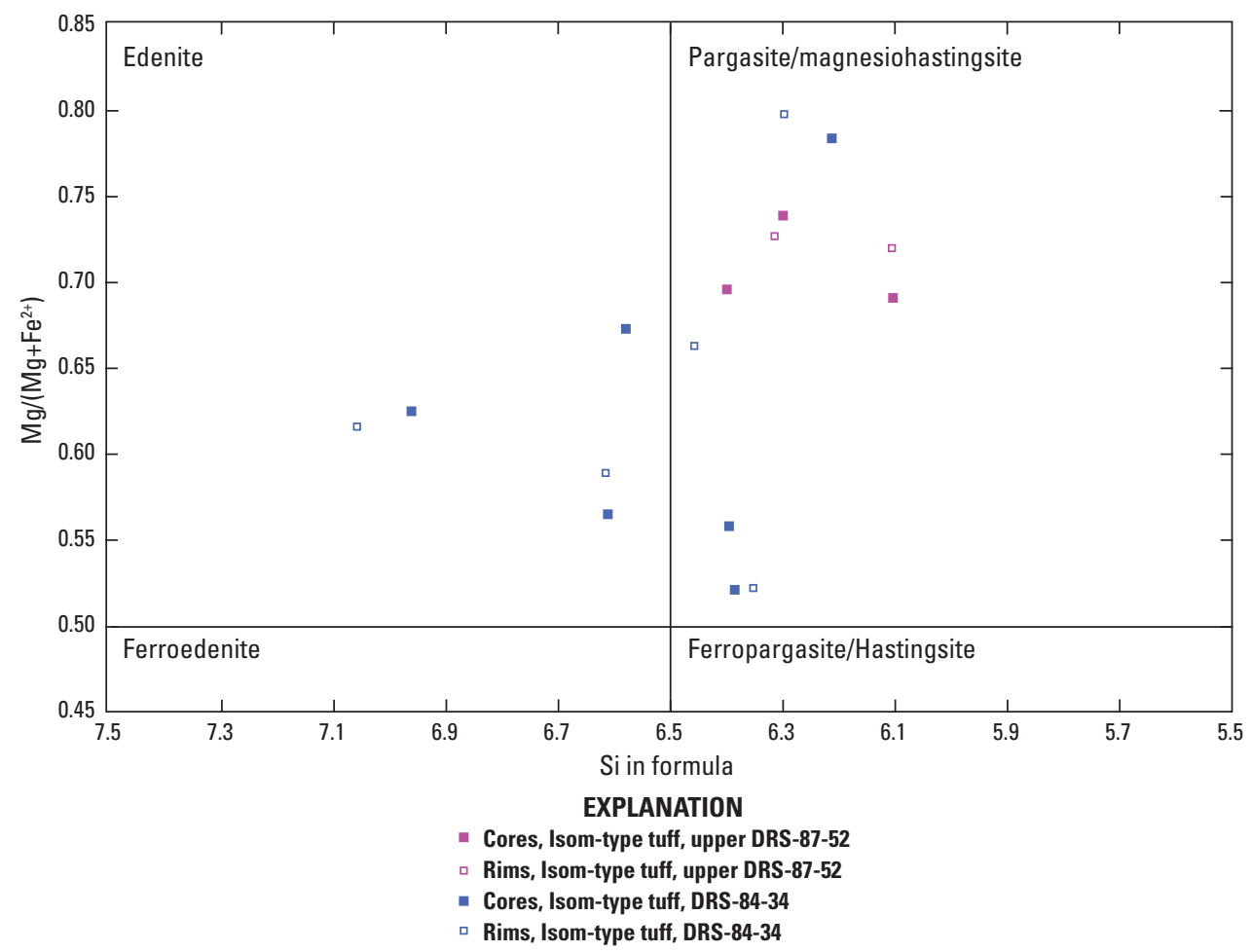

Figure 22. Diagram showing relative cation abundances of $\mathrm{Si}$ and $\mathrm{Mg} /\left(\mathrm{Mg}+\mathrm{Fe}^{2+}\right)$ in hornblende of two samples, southern Toquima Range, Nye County, Nevada. (Samples DRS-87-52 and DRS-84-34; unit Ti of Shawe, 1999b)

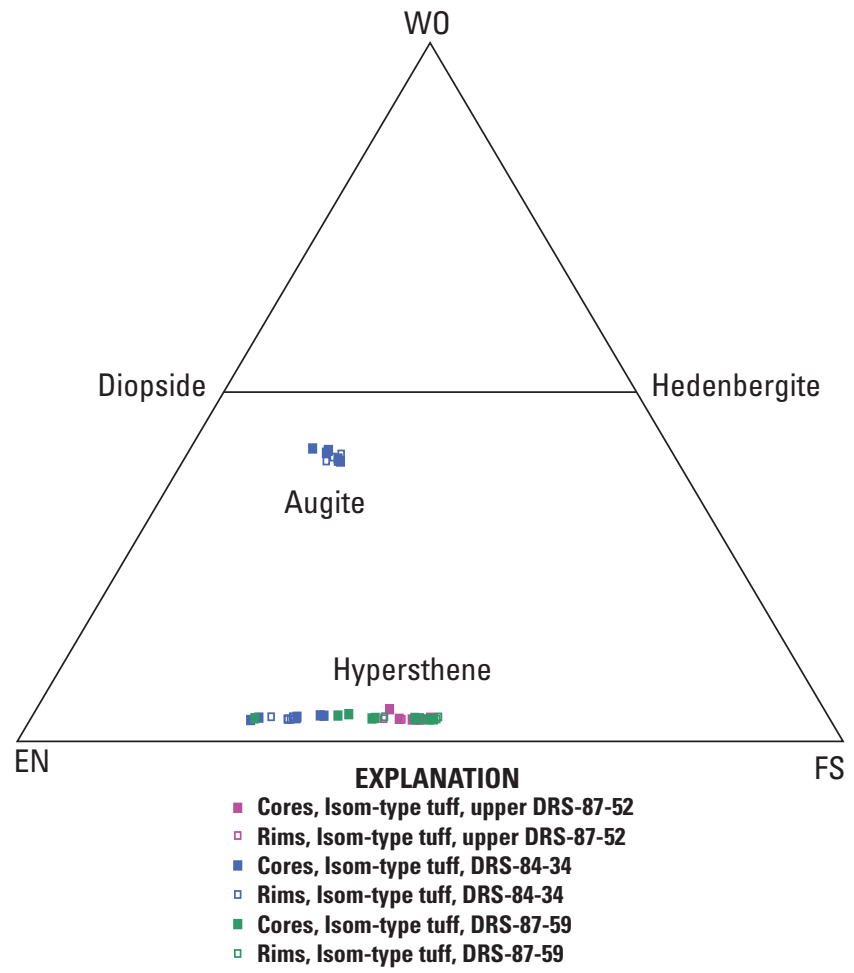

Figure 23. Ternary diagram showing proportions of wollastonite, enstatite, and ferrosilite in pyroxenes in three samples, southern Toquima Range, Nye County, Nevada. (Samples DRS-87-52, DRS-84-34, and DRS-87-59, unit Ti of Shawe, 1999b; WO, wollastonite; EN, enstatite; FS, ferrosilite)

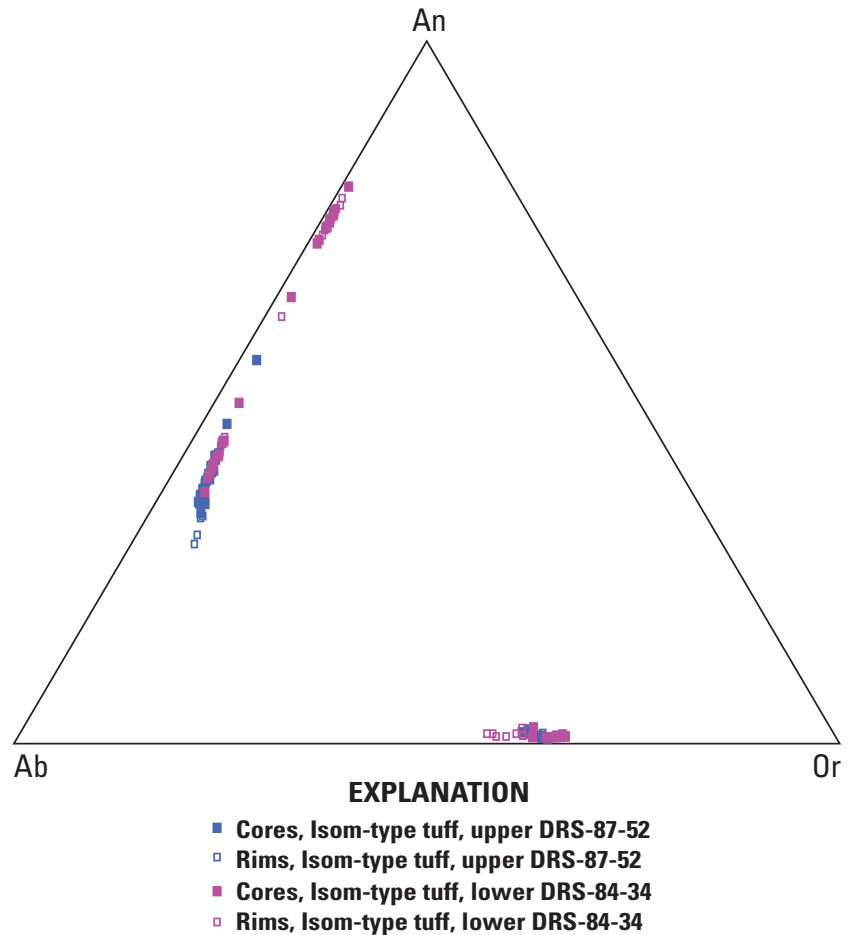

Figure 24. Ternary diagram showing molecular end-member proportions of albite, anorthite, and orthoclase feldspars in two samples, southern Toquima Range, Nye County, Nevada. (Samples DRS-87-52 and DRS-87-34; unit Ti of Shawe,1999b; Ab, albite; An, anorthite; Or, orthoclase) 
Mountain Tuff is not possible. Establishing the petrogenesis of the Bates Mountain is further stymied because the map area includes at least three eruptive units of unknown relative stratigraphic position. Nevertheless, amphibole and feldspar composition variations indicate that their source magmas had distinct compositions. The composition of amphibole in sample DRS-91-3 (fig. 25) has slightly elevated abundances of $\mathrm{Ca}$ and values for $2 \mathrm{Mg} /\left(\mathrm{Mg}+\mathrm{Fe}^{2+}\right)$ relative to Ti abundances as compared with amphibole from sample DRS-91-6 (fig. 25). Amphibole in sample DRS-91-3 is ferroedenite, whereas that in sample DRS-91-6 is pargasite/magnesiohastingsite (fig. 26). Plagioclase in sample DRS-91-3 contains approximately equal amounts of anorthite and albite components (fig. 27), whereas that in sample DRS-91-25 contains a distinctly greater albite component, which suggests a distinctly more evolved source magma. Likewise, sanidine in sample DRS-91-25 is distinctly enriched in the orthoclase component, also indicative of slightly more evolved source magma. Consequently, magma represented by sample DRS-91-3 was less evolved than that of either sample DRS-91-6 or sample DRS-91-25.

\section{Petrogenesis of the Tuff of Mount Jefferson (Unit Tmj), and Its Possible Relation to Other Tuffs}

A transitional zone a few hundred meters thick, near the top of the principal member of the tuff of Mount Jefferson (Tmj) and just below overlying volcaniclastic rocks of Little Table Mountain (Tlt), contains several features that help characterize the late evolution of the source magma reservoir. The zone is exposed on the southwest side of Corcoran Canyon about $2 \mathrm{~km}$ east of the summit of Little Table Mountain (Shawe, Hardyman, and Byers, 2000) (fig. 1). A dark-gray crystal-poor vitrophyre crops out between underlying crystal-poor welded ash-flow tuff and overlying crystal-rich welded ash-flow tuff; this tuff grades upward through interlayered tuff, tuff breccia, and sandstone-conglomerate into sandstone and siltstone at the base of volcaniclastic rocks of Little Table Mountain (TIt). A ${ }^{40} \mathrm{Ar} /{ }^{39} \mathrm{Ar}$ date on a sample of the dark-gray vitrophyric layer is $26.80 \pm 0.03 \mathrm{Ma}$ (sample R9, Shawe, Hardyman, and Byers, 2000; sample DRS-91-98, Tmj, this report), and a ${ }^{40} \mathrm{Ar} /{ }^{39} \mathrm{Ar}$ date on a sample of ash-flow tuff collected about $50 \mathrm{~m}$ higher in the section is $26.70 \pm 0.03 \mathrm{Ma}$ (sample DRS-91-169, Tmj, pl. 1; also, sample R8, Shawe, Hardyman, and Byers, 2000; sample DRS-91-171, Tmj, this report). As indicated by Shawe, Hardyman, and Byers (2000), tuff immediately underlying the vitrophyre has a PI of 3, the vitrophyre a PI of 4, and immediately overlying tuff a PI of 1 . Higher tuff layers have PIs of 3, 4, and 5, but the geologic context of these samples is such that stratigraphic positions are uncertain. The sample of the tuff underlying the vitrophyre (DRS-91-168), and a sample of the vitrophyre (DRS-91-169), collected about $15 \mathrm{~m}$ apart stratigraphically, have similar PIs (3 and 4, respectively) and have virtually indistinguishable biotite compositions (fig. 12),

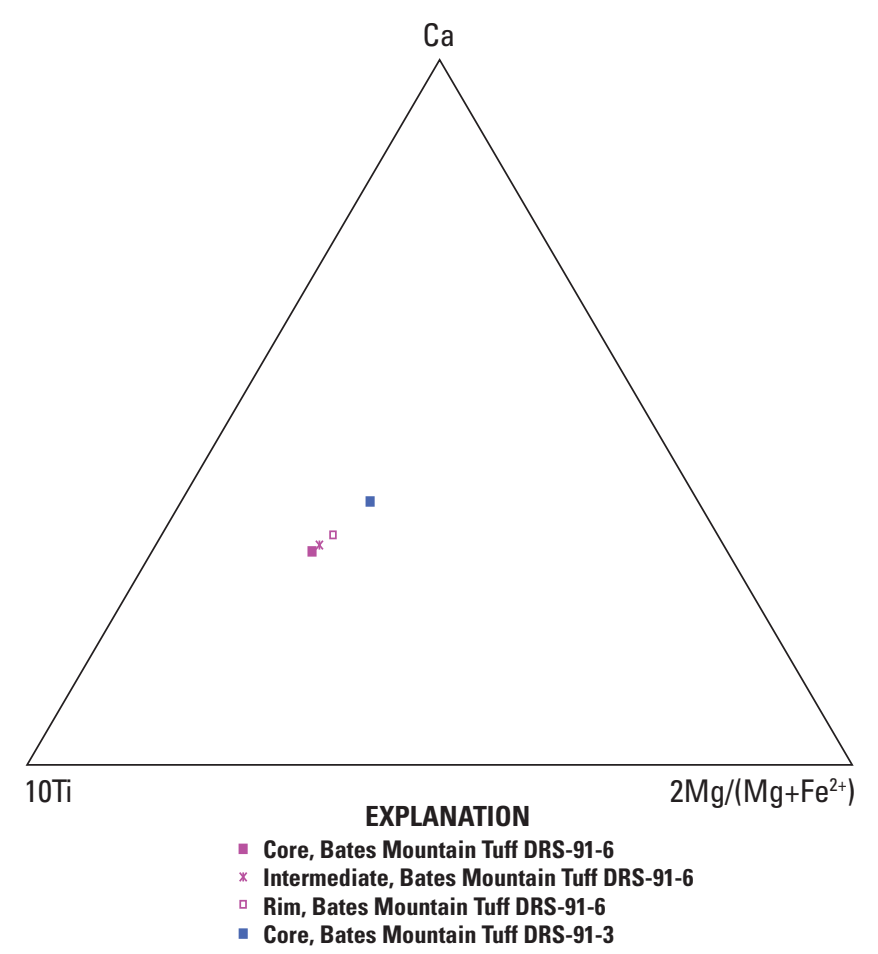

Figure 25. Ternary diagram of $\mathrm{Ca}-10 \mathrm{Ti}-2 \mathrm{Mg} /\left(\mathrm{Mg}+\mathrm{Fe}^{2+}\right)$ showing relative cation abundances in hornblende of two samples, southern Toquima Range, Nye County, Nevada. (Samples DRS-91-6 and DRS-91-3; unit Ty of Shawe, 1999b)

but each sample includes two distinct biotite composition fields that vary slightly in relative $\mathrm{MgO}$ and $\mathrm{Fe}^{2+}+\mathrm{MnO}$ ratios. Analyses of hornblende phenocrysts in sample DRS-91-169 (fig. 13, no data for DRS-91-168) also define two distinct compositional fields characterized by significantly different $\mathrm{MgO} / \mathrm{Fe}^{2+}+\mathrm{MnO}$ ratios. Analyses of pyroxene phenocrysts in samples of the tuff of Mount Jefferson (Tmj) indicate its crystallization only in the lower, less evolved layer of a zoned magma reservoir (fig. 19).

- $26.70 \pm 0.03 \mathrm{Ma}\left({ }^{40} \mathrm{Ar} /{ }^{39} \mathrm{Ar}\right.$ on ash-flow tuff; this report)

- $26.80 \pm 0.03 \mathrm{Ma}\left({ }^{40} \mathrm{Ar} /{ }^{39} \mathrm{Ar}\right.$ on dark-gray vitrophyric layer; this report)

Boden (1989) used compositions of glass (fiamme) and biotite to suggest that the ash-flow tuff units erupted from his Toquima caldera complex reflect eruption from a compositionally zoned magma reservoir. Our results corroborate Boden's (1989) conclusion. However, we conclude that the compositional similarity of phenocrysts in the tuff of Mount Jefferson and in Boden's tuff of Trail Canyon (Boden, 1986, 1992) indicates that the two are parts of a single ashflow tuff (tuff of Mount Jefferson (Tmj)), as is consistent with ${ }^{40} \mathrm{Ar} r{ }^{39} \mathrm{Ar}$ age dates and petrographic data.

Compositions of biotite, hornblende, and clinopyroxene in a sample (DRS-92-1) of vitrophyre from the megabreccia of Jefferson Canyon (Tjc) are distinct relative to those from samples of the tuff of Mount Jefferson (see appendixes 3, 6, 


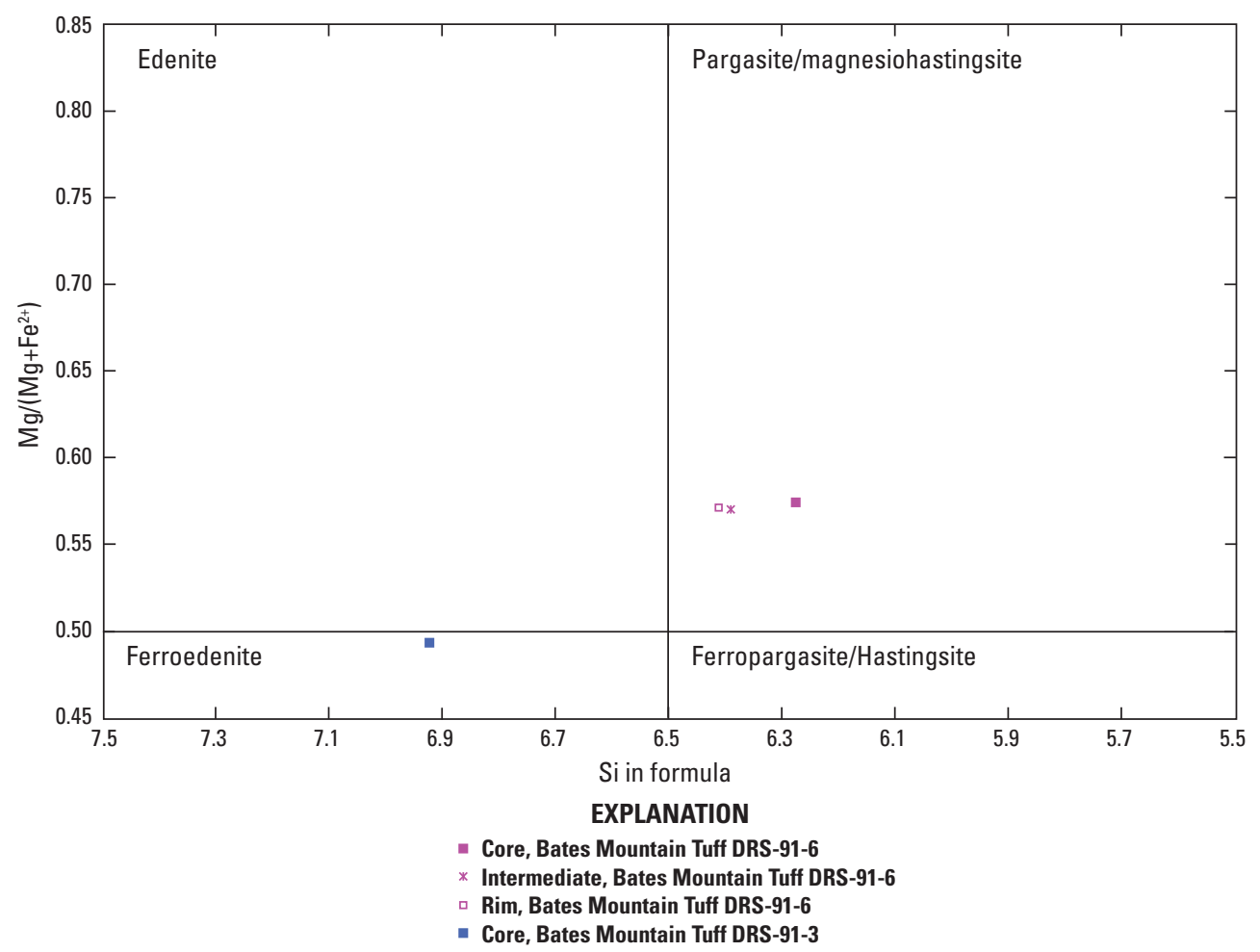

Figure 26. Diagram showing relative cation abundances of $\mathrm{Si}$ and $\mathrm{Mg} /\left(\mathrm{Mg}+\mathrm{Fe}^{2+}\right)$ in hornblende of two samples, southern Toquima Range, Nye County, Nevada. (Samples DRS-91-6 and DRS-91-3; unit Ty of Shawe, 1999b)

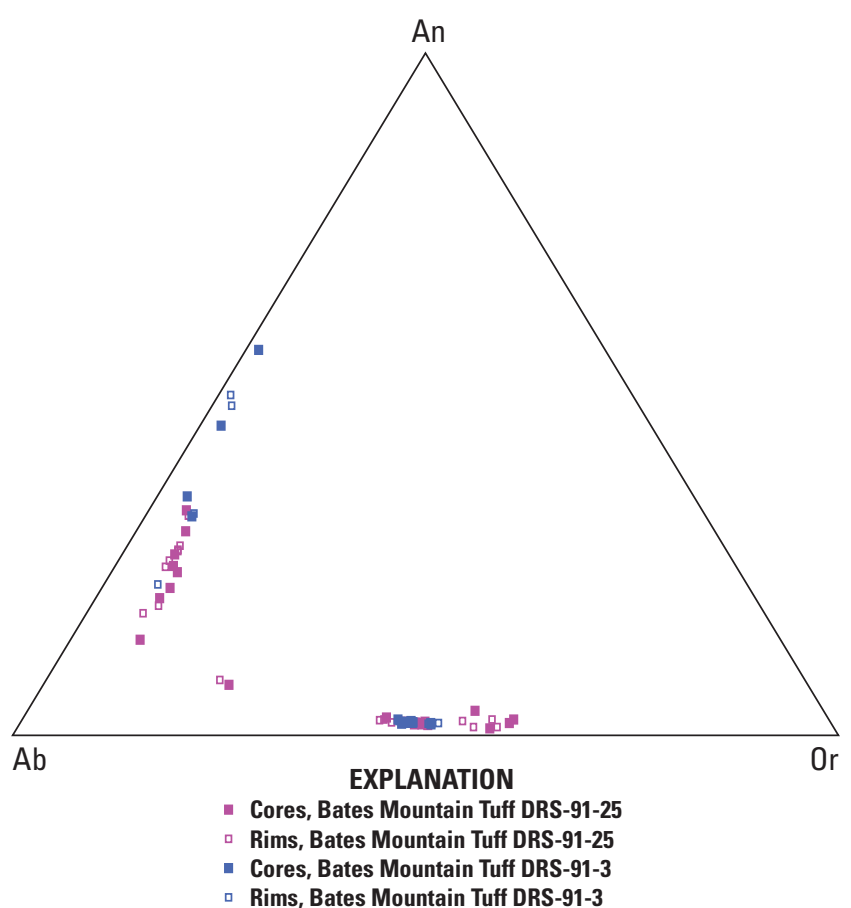

Figure 27. Ternary diagram showing molecular end-member proportions of albite, anorthite, and orthoclase in feldspars in two samples, southern Toquima Range, Nye County, Nevada. (Samples DRS-91-25 and DRS-91-3; unit Ty of Shawe, 1999b; Ab, albite; An, anorthite; Or, orthoclase) and 8 and figs. $3,12-17$, and 19). The distinction suggests that the megabreccia is not related to the volcanic rocks of the Mount Jefferson caldera, as Shawe (1995) previously suggested. Provided that the vitrophyre is not a clast in the megabreccia of Jefferson Canyon, the distinction makes more probable the conclusions of Boden $(1986,1992)$, Henry and others (1996), and Henry (1997) and, supported by age data, that the megabreccia is related to a caldera now largely buried beneath the alluvium of Big Smoky Valley.

\section{Interpretative Summary of Phenocryst Compositions}

Compositions of biotite, amphibole, and augite in parts of both the tuffs of Corcoran Canyon and Ryecroft Canyon are remarkably similar to those in parts of the tuff of Mount Jefferson. In samples of these tuffs for which compositions of augite and feldspars were also determined, compositions of these phenocrysts are particularly similar as well. Phenocryst composition similarities among the tuffs of Corcoran Canyon, Ryecroft Canyon, and Mount Jefferson suggest a common origin and petrogenesis of the magmas that produced these welded ash-flow tuffs. The apparent age span of the petrogenetically related calderas that produced ash-flow tuffs extends from about 27.17 to $26.61 \mathrm{Ma}$. Consequently, development of this segment of the southern Toquima caldera complex transpired during about 560,000 years. 
Compositions of phenocrysts from the younger Isomtype and Bates Mountain Tuff indicate that the petrogenesis of these units is unrelated to that of the tuffs that had sources within our map area; consequently they are derived from sources external to the Toquima Range.

\section{The Southern Toquima Range Caldera Complex, a Summary}

Nine calderas characterize the southern Toquima Range as a major center of volcanic activity during the late Eocene, Oligocene, and earliest Miocene (about 34-24 million years ago; see plate 1 , list of map units). In succession (oldest to youngest) these are the inferred Dry Canyon, the Northumberland, the poorly defined Corcoran Canyon, the Big Ten Peak, the inferred Ryecroft Canyon, the Moores Creek, the Mount Jefferson, the Round Mountain (which is mostly covered by alluvium in the Big Smoky Valley), and the Manhattan calderas. The ash-flow tuffs erupted from these calderas are calc-alkalic trachydacites to rhyolites. Plugs and dikes are associated with all of the calderas, have compositions similar to those of the associated tuffs, and were emplaced along or near caldera margins. Eruptive megabreccias at or near caldera margins, or forming outflow or interlayered units, characterize several of the calderas. Collapse megabreccias are probable components of some of the calderas and may be associated with eruptive megabreccia deposits.

Regional northwest-southeast-striking faults likely controlled development of some of the calderas; the southwest structural margins of the Manhattan, Mount Jefferson, and Big Ten Peak calderas seem to have been particularly influenced by these faults.

Tertiary igneous activity prior to development of the southern Toquima Range caldera complex included late Eocene (about 36 million years ago) emplacement of a few plugs and many dikes composed of granodiorite and andesite to rhyolite. Volcanic rocks in the area derived from outside sources and having ages similar to those of the younger caldera rocks were emplaced during the Oligocene (about 26-25 million years ago).

\section{Acknowledgments}

Greg Meeker of the U.S. Geological Survey provided valuable suggestions to Byers on operation of the microprobe and results of the microprobe analyses. Shawe acknowledges the U.S. Geological Survey Pecora Fellowship and Bradley Scholarship programs for its support. Similarly, U.S. Geological Survey Mineral Resources Program support for work in the Toquima Range has been critical to the success of these activities. Constructive reviews by R.D. Taylor and Harald Drewes helped clarify our presentation and are much appreciated.

\section{References}

Best, M.G., Christiansen, E.H., Deino, A.L., Gromme, C.S., McKee, E.H., and Noble, D.C., 1989, Excursion 3AEocene through Miocene volcanism in the Great Basin of the western United States, in Chapin, C.E., and Zidek, J., eds., Field excursions to volcanic terranes in the western United States, volume II - Cascades and Intermountain West: New Mexico Bureau of Mines and Mineral Resources Memoir 47, p. 91-133.

Boden, D.R., 1986, Eruptive history and structural development of the Toquima caldera complex, central Nevada: Geological Society of America Bulletin, v. 97, p. 61-74.

Boden, D.R., 1989, Evidence for step-function zoning of magma and eruptive dynamics, Toquima caldera complex, Nevada: Journal of Volcanology and Geothermal Research, v. 37, p. 39-57.

Boden, D.R., 1992, Geologic map of the Toquima caldera complex, central Nevada: Nevada Bureau of Mines and Geology Map 98, scale 1:48,000.

Brem, G.F., John, D.A., Nash, J.T., Poole, F.G., and Snyder, D.B., 1991, Mineral resources of the Arc Dome Wilderness Recommendation Area, Nye County, Nevada: U.S. Geological Survey Bulletin 1961, 21 p.

Brem, G.F., and Snyder, D.B., 1983, Lithology and gravity characteristics of the southern Peavine volcanic center, Toiyabe Range, Nevada: Geological Society of America Abstracts with Program, v. 15, no. 5, p. 280.

Dalrymple, G.B., Alexander, B.C., Lanphere, M.A., and Kraker, G.P, 1981, Irradiation of samples for ${ }^{40} \mathrm{Ar} /{ }^{39} \mathrm{Ar}$ dating using the Geological Survey TRIGA reactor: U.S. Geological Survey Professional Paper 1176, 55 p.

Dodge, F.C.W., Smith, V.C., and Mays, R.E., 1969, Biotites from granitic rocks of the central Sierra Nevada batholith, California: Journal of Petrology, v. 10, p. 250-271.

Ferguson, H.G., 1921, The Round Mountain district, Nevada: U.S. Geological Survey Bulletin 725-I, p. 383-406.

Ferguson, H.G., 1924, Geology and ore deposits of the Manhattan district, Nevada: U.S. Geological Survey Bulletin 723, $163 \mathrm{p}$.

Ferguson, H.G., and Cathcart, S.H., 1954, Geology of the Round Mountain quadrangle, Nevada: U.S. Geological Survey Quadrangle Map GQ-40, scale 1:125,000.

Fleck, R.J., Sutter, J.H., and Elliot, D.H., 1977, Interpretation of discordant ${ }^{40} \mathrm{Ar} /{ }^{39} \mathrm{Ar}$ age-spectra of Mesozoic tholeiites from Antarctica: Geochimica et Cosmochimica Acta, v. 41, p. $15-32$. 
Henry, C.D., 1997, Recent progress in understanding caldera development and mineralization of the southern Toquima Range near Round Mountain, Nevada: Fall 1997 Field Trip Guidebook, Geological Society of Nevada Special Publication 26, p. 241-246.

Henry, C.D., Castor, S.B., and Elson, H.B., 1996, Geology and ${ }^{40} \mathrm{Ar} /{ }^{39} \mathrm{Ar}$ geochronology of volcanism and mineralization at Round Mountain, Nevada, in Conyer, A.R., and Fahey, P.L., eds., Geology and ore deposits of the American Cordillera, Reno/Sparks, Nevada, April 1995, Symposium Proceedings: Geological Society of Nevada publication 95-1, v. 1, p. 283-307.

John, D.A., 1992, Stratigraphy, regional distribution, and reconnaissance geochemistry of Oligocene and Miocene volcanic rocks in the Paradise Range and northern Pactolus Hills, Nye County, Nevada: U.S. Geological Survey Bulletin 1974, $67 \mathrm{p}$.

Keith, W.J., 1987, Preliminary geologic map of the Big Ten Peak quadrangle, Nye County, Nevada: U.S. Geological Survey Open-File Report 87-7, scale 1:62,500.

Keith, W.J., 1993, Megabreccia of the Big Ten Peak Caldera, Nye County, Nevada: U.S. Geological Survey Open-File Report 93-21, 16 p.

Leake, B.E., Woolley, A.R., Arps, C.E.S., Birch, W.D., Gilbert, M.C., Grice, J.D., Hawthorne, F.C., Kato, Akira, Kisch, H.J., Krivovichev, V.G., Linthout, Kees, Laird, Jo, Mandarino, J.A., Maresch, W.V., Nickel, E.H., Rock, N.M.S., Schumacher, J.C., Smith, D.C., Stephenson, N.C.N., Ungaretti, Luciano, Whitaker, E.J.W., and Youzhi, Guo, 1997, Nomenclature of amphiboles-Report of the Subcommittee on Amphiboles of the International Mineralogical Association, Commission on New Minerals and Mineral Names: American Mineralogist, v. 82, no. 9-10, p. 1019-1037.

Le Bas, M.J., Le Maitre, R.W., Streckeisen, A., and Zanettin, B.A., 1986, A chemical classification of volcanic rocks based on the total alkali-silica diagram: Journal of Petrology, v. 27, p. 745-750.

Marvin, R.F., Mehnert, H.H., and McKee, E.H., 1973, A summary of radiometric ages of Tertiary volcanic rocks in Nevada and eastern California; Part 3; southeastern Nevada: Isochron/West, no. 6, p. 1-30.

McKee, T.H., 1974, Northumberland caldera and Northumberland Tuff, in Guidebook to the geology of four Tertiary volcanic centers in central Nevada: Nevada Bureau of Mines and Geology Report 19, p. 35-41.

McKee, T.H., and John, D.A., 1987, Sample location map and potassium-argon ages and data for Cenozoic igneous rocks in the Tonopah 1 degree by 2 degree quadrangle, central Nevada: U.S. Geological Survey Miscellaneous Field Studies Map MF-1877-I, scale 1:250,000.
Renne, P.R., Swisher, C.C., Deino, A.L., Karner, D.B., Owens, T.L., and DePaolo, D.J., 1998, Intercalibration of standards, absolute ages and uncertainties in ${ }^{40} \mathrm{Ar} /{ }^{39} \mathrm{Ar}$ dating: Chemical Geology, v. 145, p. 117-152.

Roddick, J.C., 1983, High precision intercalibration of ${ }^{40} \mathrm{Ar} /{ }^{39} \mathrm{Ar}$ standards: Geochimica et Cosmochimica Acta, v. 47, p. $887-898$.

Samson, S.D., and Alexander, E.G., 1987, Calibration of interlaboratory ${ }^{40} \mathrm{Ar} /{ }^{39} \mathrm{Ar}$ dating standard MMhb-1: Isotope Geoscience, v. 66, p. 27-34.

Shawe, D.R., 1981, Geologic map of the Round Mountain quadrangle, Nye County, Nevada: U.S. Geological Survey Open-File Report 81-515, scale 1:24,000.

Shawe, D.R., 1987, Stratigraphic nomenclature of volcanic rocks near Manhattan, southern Toquima Range, Nye County, Nevada: U.S. Geological Survey Bulletin 1775-A, p. A1-A8.

Shawe, D.R., 1988, Complex history of precious metal deposits, southern Toquima Range, Nevada, in Schafer, R.W., Cooper, J.J., and Vikre, P.G., eds., Bulk Mineable Precious Metal Deposits of the Western United States, Symposium Proceedings, Reno, Nevada, 1987: Geological Society of Nevada publication 87-1, p. 333-373.

Shawe, D.R., 1995, Geologic map of the Round Mountain quadrangle, Nye County, Nevada: U.S. Geological Survey Geologic Quadrangle Map GQ-1756, scale 1:24,000.

Shawe, D.R., 1998, Geologic map of the Belmont West quadrangle, Nye County, Nevada: U.S. Geological Survey Geologic Quadrangle Map GQ-1801, scale 1:24,000.

Shawe, D.R., 1999a, Geologic map of the Manhattan quadrangle, Nye County, Nevada: U.S. Geological Survey Geologic Quadrangle Map GQ-1775, scale 1:24,000.

Shawe, D.R., 1999b, Geologic map of the Jefferson quadrangle, Nye County, Nevada: U.S. Geological Survey Geologic Investigations Series Map I-2670, scale 1:24,000.

Shawe, D.R., 2001, Map of steep structure in part of the southern Toquima Range and adjacent areas, Nye County, Nevada: U.S. Geological Survey Miscellaneous Field Studies Map MF-2327-B, scale 1:48,000.

Shawe, D.R., 2002, Geologic map of part of the southern Toquima Range and adjacent areas, Nye County, Nevada: U.S. Geological Survey Miscellaneous Field Studies Map MF-2327-A, scale 1:48,000.

Shawe, D.R., 2003a, Geologic map of part of the southern Toquima Range and adjacent areas, Nye County, Nevada: U.S. Geological Survey Miscellaneous Field Studies Map MF-2327A, scale 1:48,000.

Shawe, D.R., 2003b, Geochemistry, geochronology, mineralogy, and geology suggest sources of and controls on mineral systems in the southern Toquima Range, Nye County, Nevada: U.S. Geological Survey Miscellaneous Field Studies Map MF-2327-C, scale 1:48,000, with pamphlet. 
Shawe, D.R., and Byers, F.M., Jr., 1999, Geologic map of the Belmont East quadrangle, Nye County, Nevada: U.S. Geological Survey Geologic Investigations Series Map I-2675, scale $1: 24,000$.

Shawe, D.R., Hardyman, R.F., and Byers, F.M., Jr., 2000, Geologic map of the Corcoran Canyon quadrangle, Nye County, Nevada: U.S. Geological Survey Geologic Investigations Series Map I-2680, scale 1:24,000.

Shawe, D.R., Kucks, R.P., and T.G. Hildenbrand, 2004, Geologic insights and comments on mineral potential based on analyses of geophysical data of the southern Toquima Range, Nye County, Nevada: U.S. Geological Survey Miscellaneous Field Studies Map I-2327-D, scale 1:48,000.

Shawe, D.R., Marvin, R.F., Andriessen, P.A.M., Mehnert, H.H., and Merritt, V.M., 1986, Ages of igneous and hydrothermal events in the Round Mountain and Manhattan gold districts, Nye County, Nevada: Economic Geology, v. 81, p. 388-407.

Shawe, D.R., Naeser, C.W., Marvin, R.F., and Mehnert, H.H., 1987, New radiometric ages of igneous and mineralized rocks, southern Toquima Range, Nye County, Nevada: Isochron/West, no. 50, p. 3-7.
Shawe, D.R., and Snyder, D.B., 1988, Ash-flow eruptive megabreccias of the Manhattan and Mount Jefferson calderas, Nye County, Nevada: U.S. Geological Survey Professional Paper 1471, 28 p.

Silberman, M.L., and McKee, E.H., 1972, A summary of radiometric age determinations on Tertiary volcanic rocks from Nevada and eastern California; part II, western Nevada: Isochron/West, no. 4, p. 7-28.

Silberman, M.L., Shawe, D.R., Koski, R.A., and Goddard, B.B., 1975, K-Ar ages of mineralization at Round Mountain and Manhattan, Nye County, Nevada: Isochron/West, no. 13, p. 1-2.

Snee, L.W., 2002, Argon thermochronology of mineral deposits-A review of analytical methods, formulations, and selected applications: U.S. Geological Survey Bulletin 2194, $39 \mathrm{p}$.

Steiger, R.H., and Jäger, E., 1977, Subcommission on geochronology: Convention on the use of decay constants in geo- and cosmochronology: Earth and Planetary Science Letters, v. 36, p. 359-362.

U.S. Geological Survey Geologic Names Committee, 2010, Divisions of geologic time-Major chronostratigraphic and geochronologic units. U.S. Geological Survey Fact Sheet 2010-3059, 2 p. 
Appendixes 



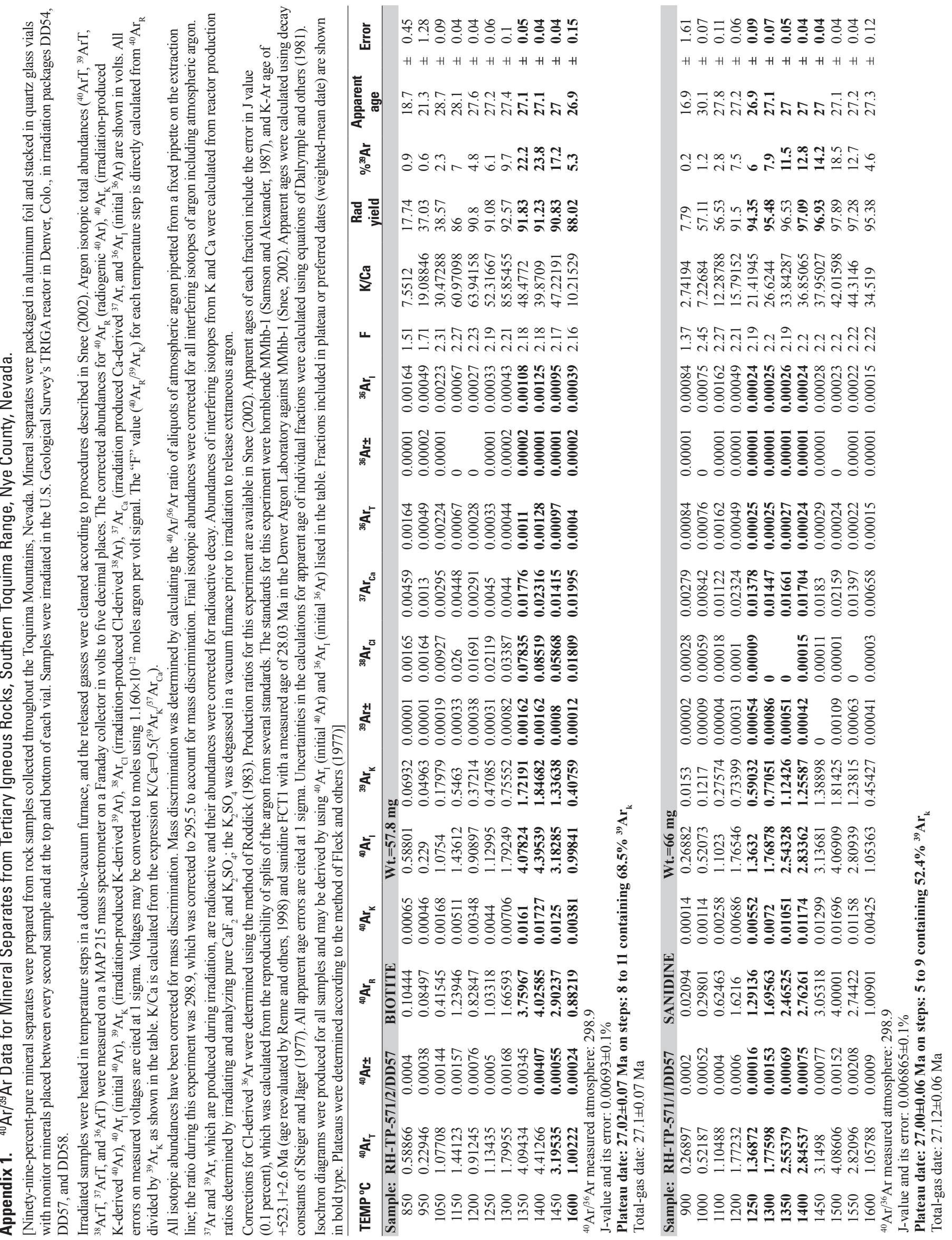




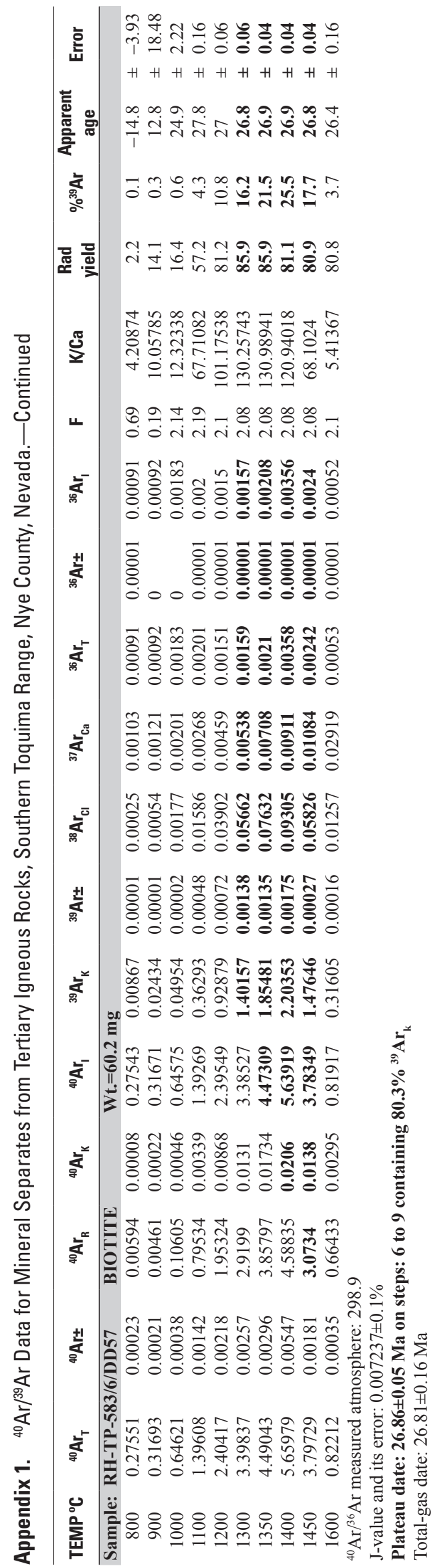

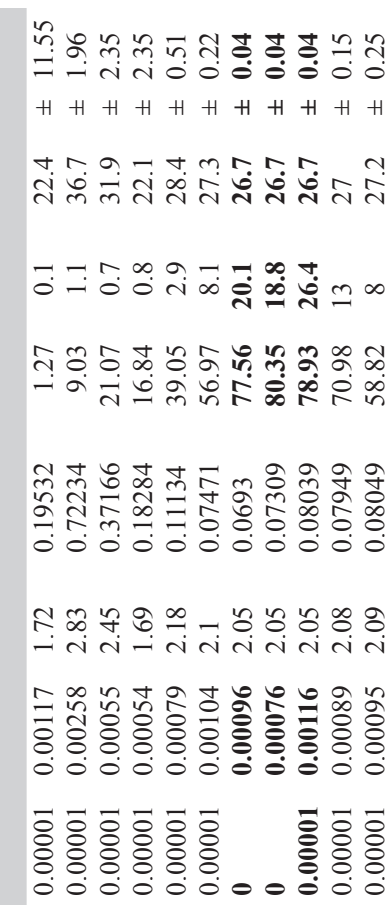

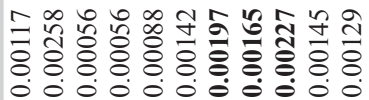

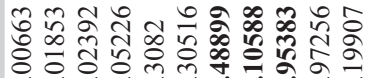

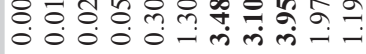

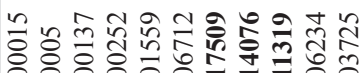

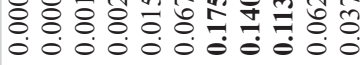

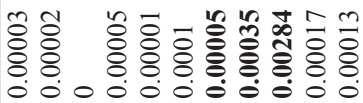

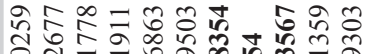

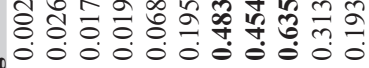
星

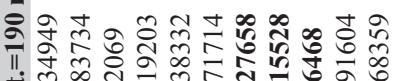

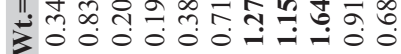

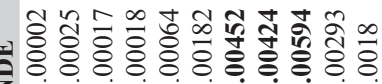

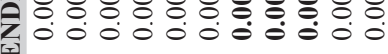

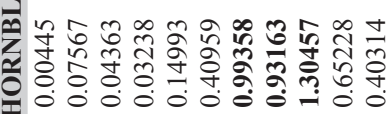

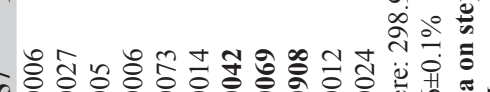

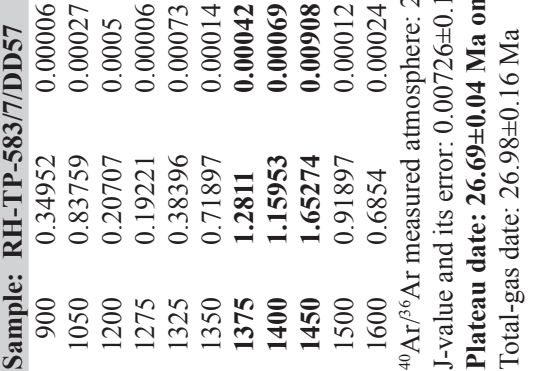

n

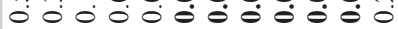
$\mathrm{H} H \mathrm{H} H \mathrm{H} H \mathrm{H} H \mathrm{H} H \mathrm{H} H \mathrm{H}$

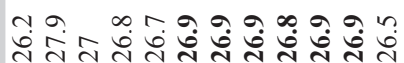

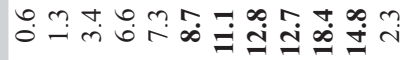
m

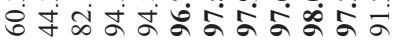

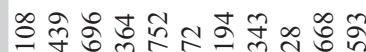

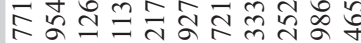
मेंतेंतें

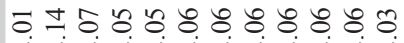
论尖

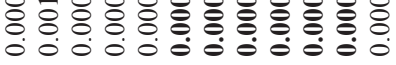

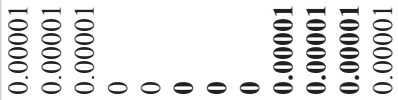

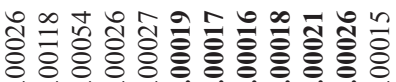

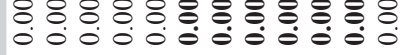
๓

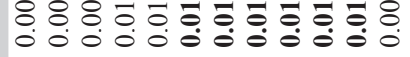

ㄴ.

8용

잉 00000000

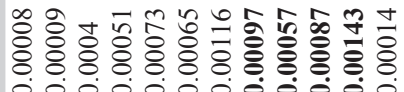

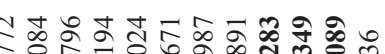

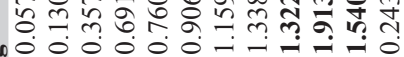
o.

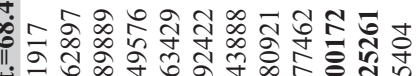

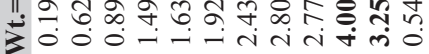

苍 సิ

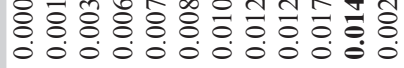
r

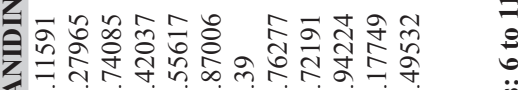

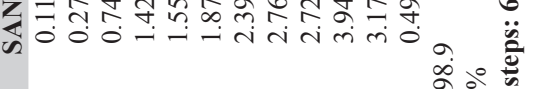

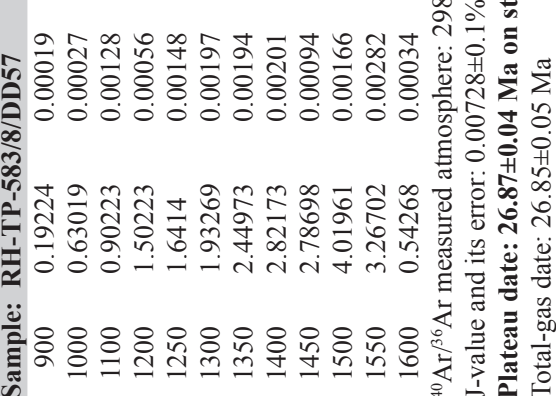




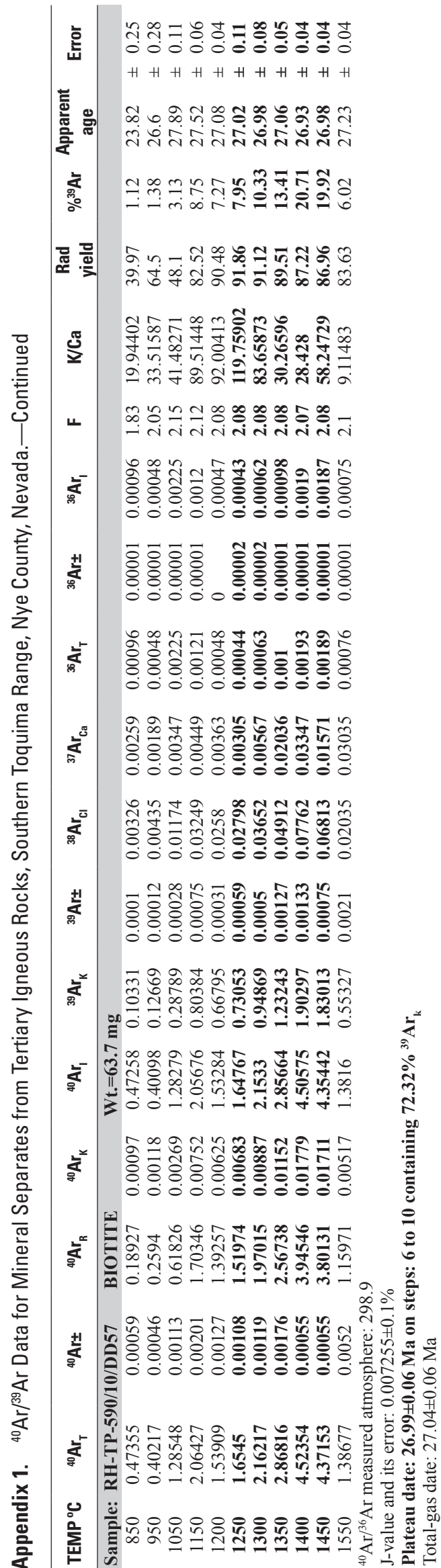

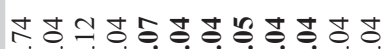

000000000000

$\mathrm{H}+\mathrm{H} H \mathrm{H} H \mathrm{H}+\mathrm{H}+\mathrm{H} H \mathrm{H} H$

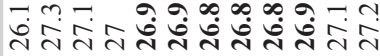

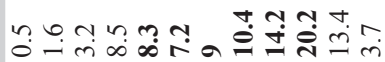

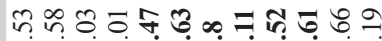

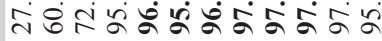

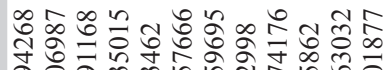

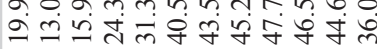

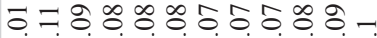

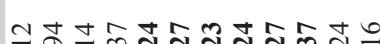

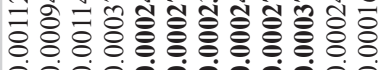

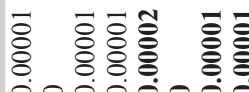

000000000000

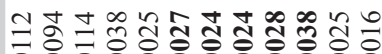

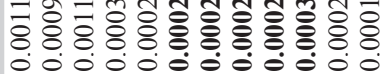

กิ

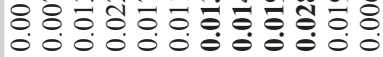

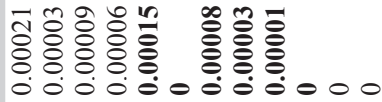

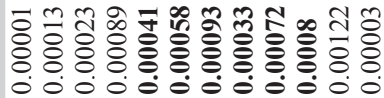

ర్రై

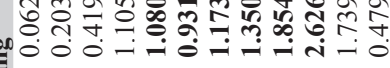

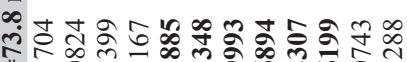

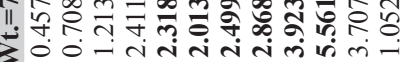

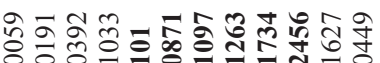

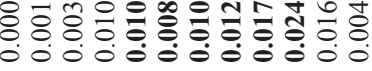
딘

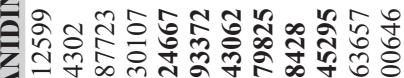

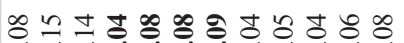

000000000000

$\mathrm{H} H \mathrm{H} H \mathrm{H} H \mathrm{H} H \mathrm{H} H \mathrm{H} H$

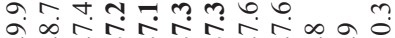

m mam

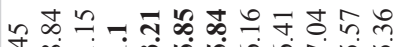

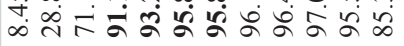

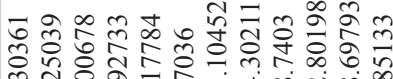
min in

กีปัป

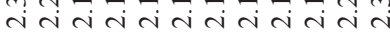

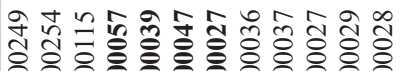
000000000000

ธีة

。

志洁䏠

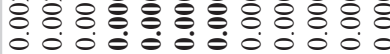

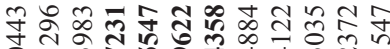

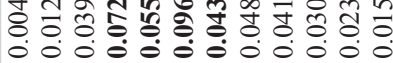

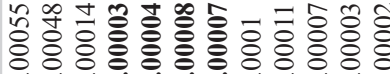

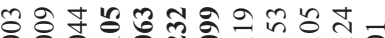

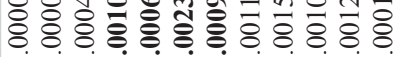
0.00000 .00000

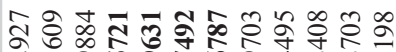
人ิ

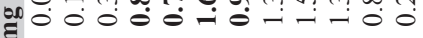

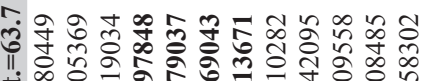

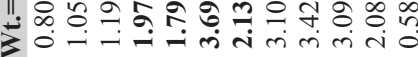

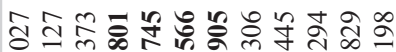

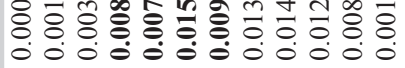
독

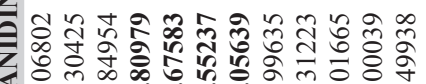
क००० -

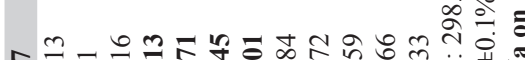

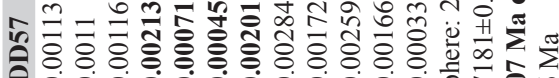

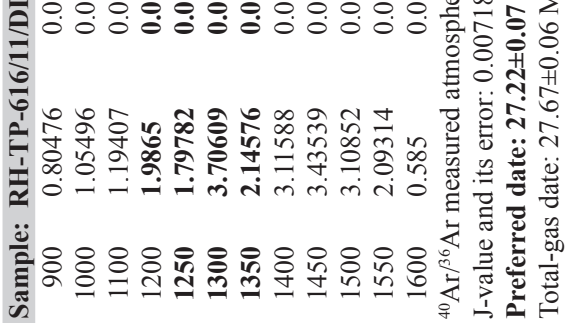




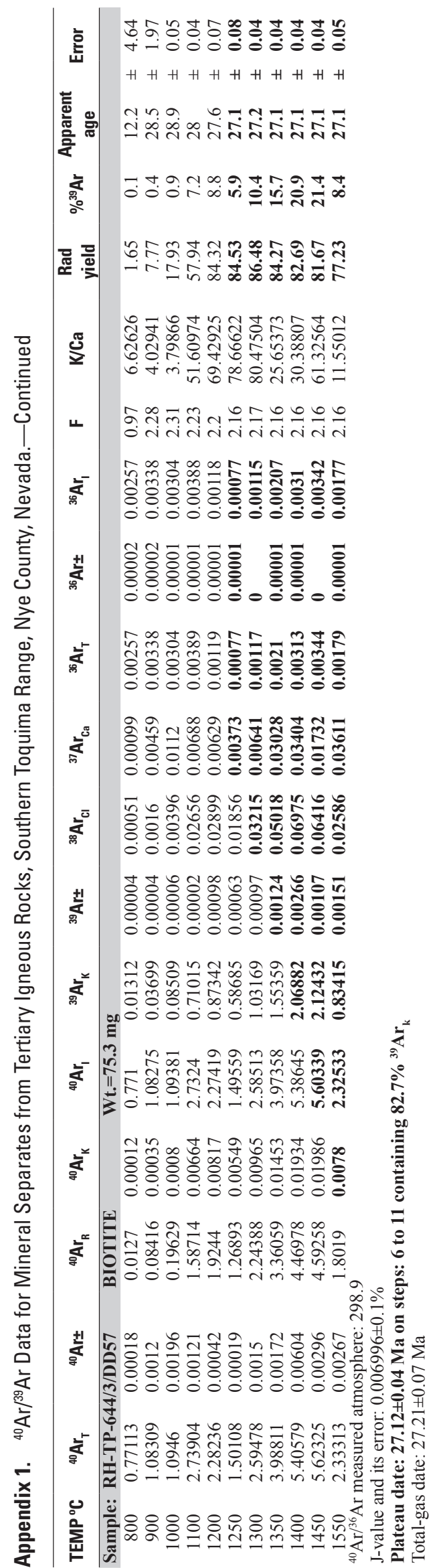

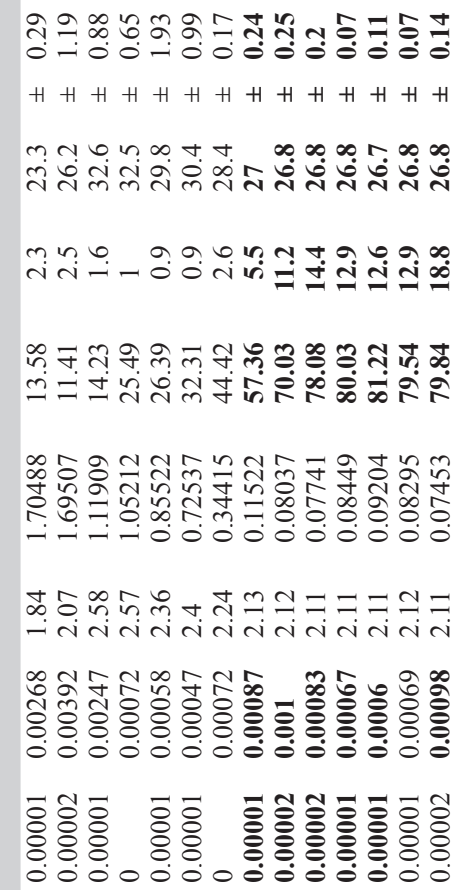

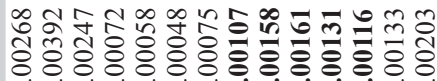

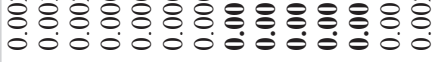

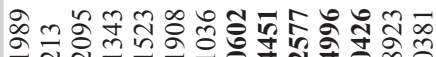

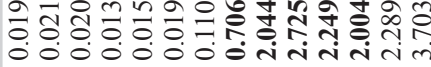

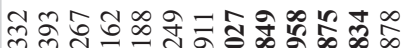

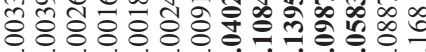

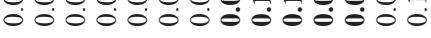

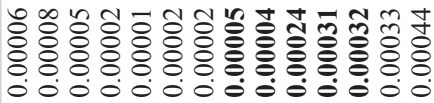

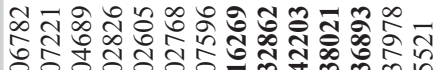

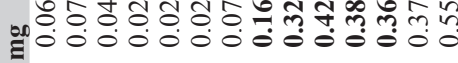

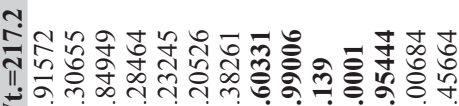

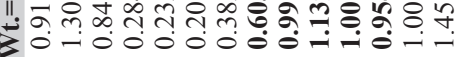

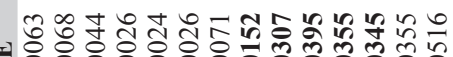

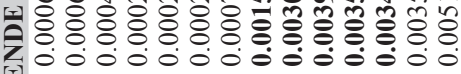

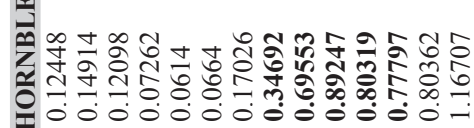

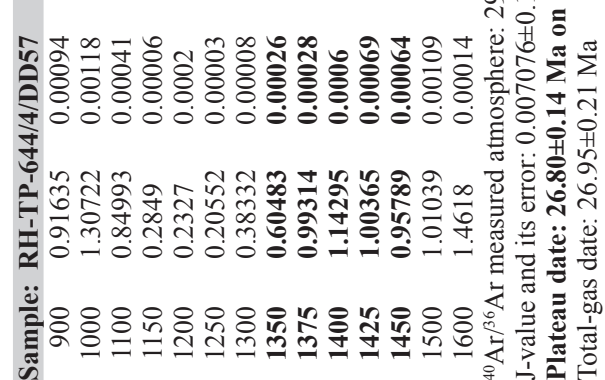

군? $H+H+H+H+H+H+H+H$ $n$ n

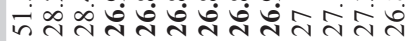
ت웅ํำ

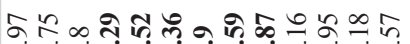

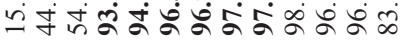

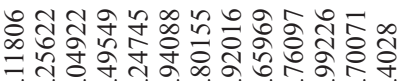

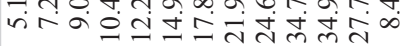

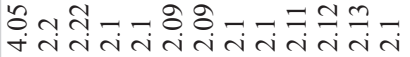

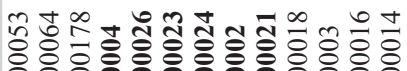

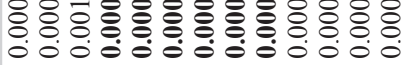

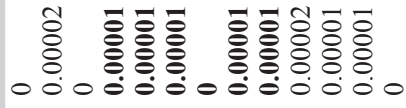

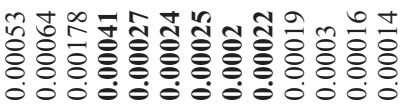

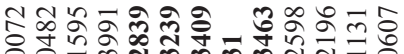

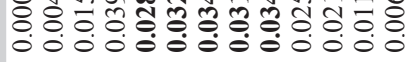

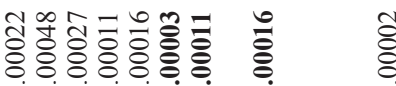

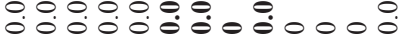
ธํㅇㅇํㅇํํำ o:

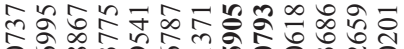

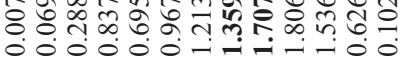
600

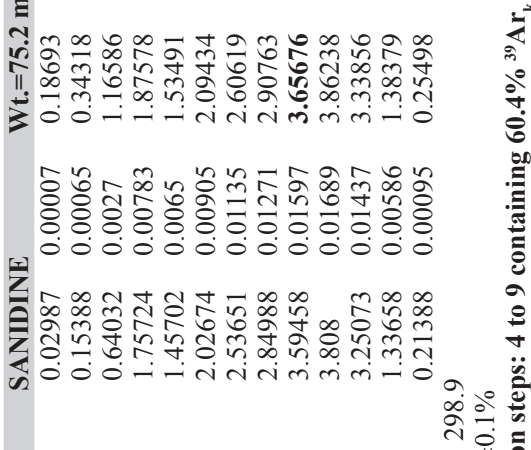

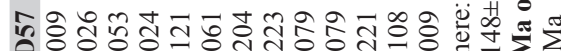

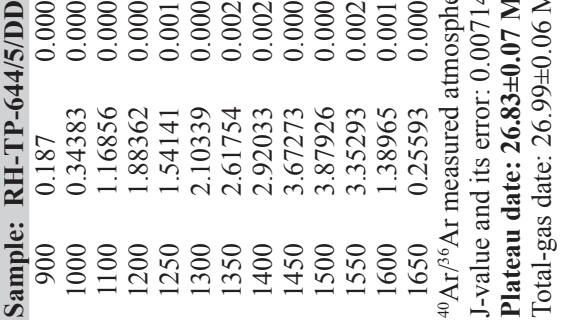



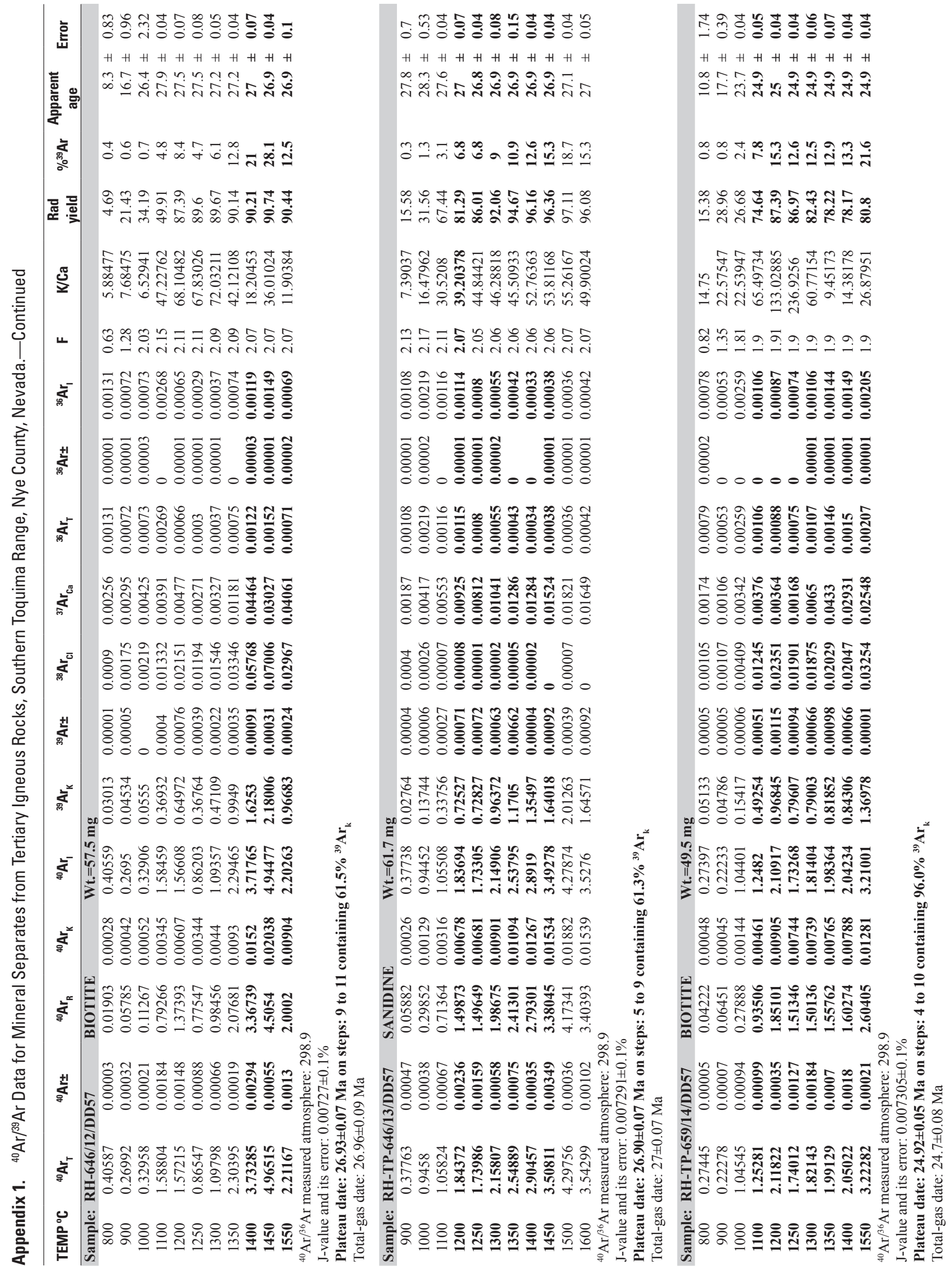

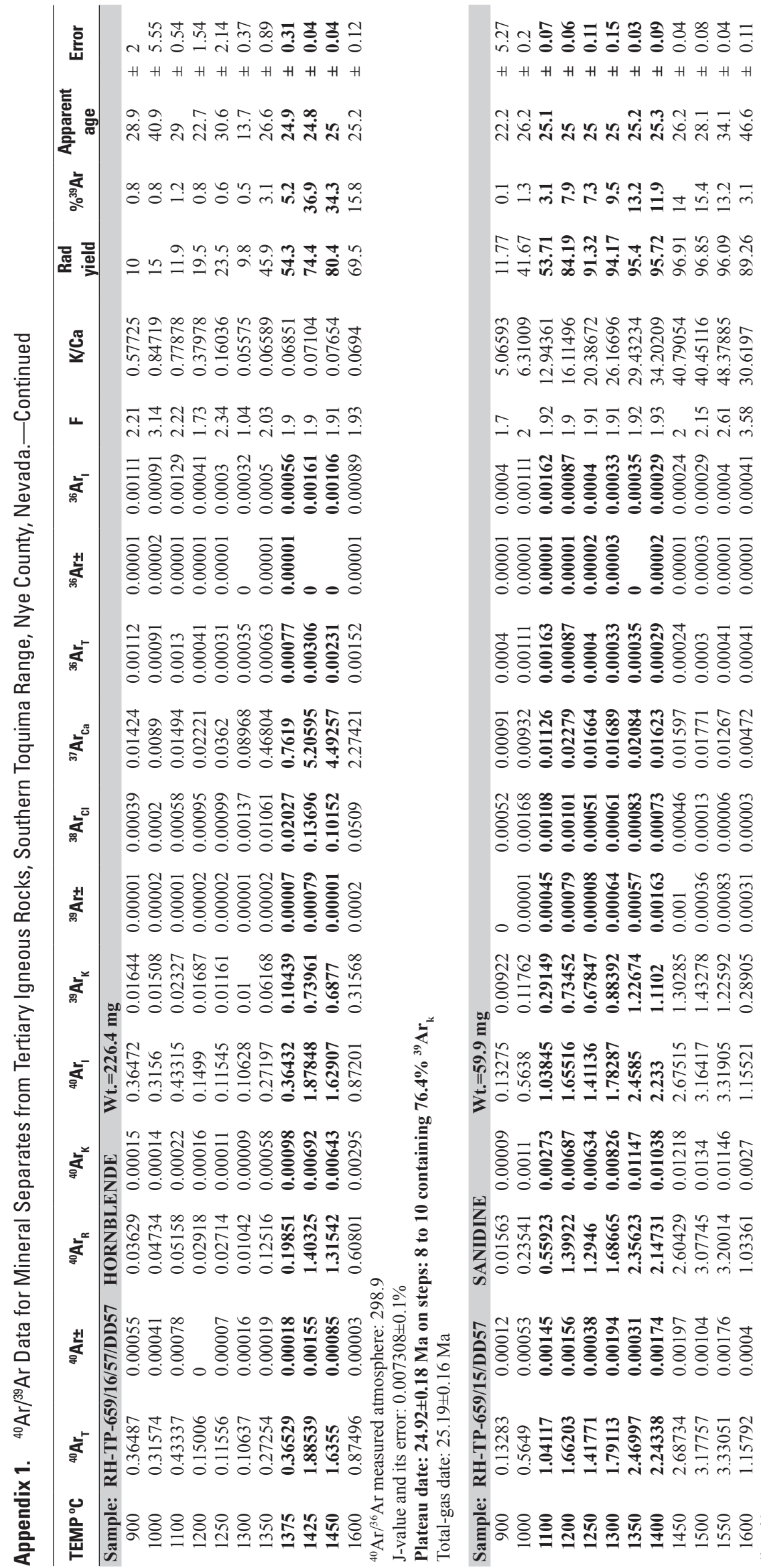

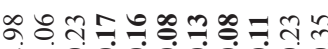

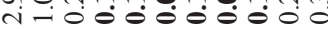
H H H H H H H H H H H

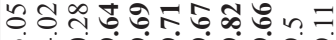

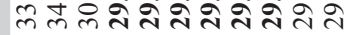

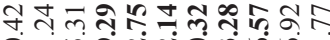
- $\rightarrow$ ing

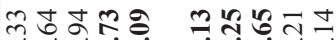

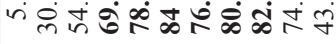

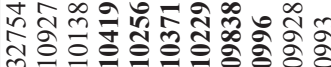

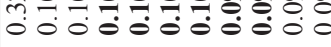

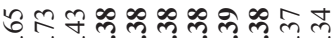
icisididisidit

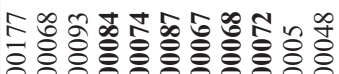
o.

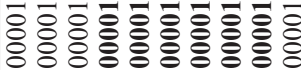

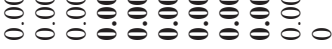

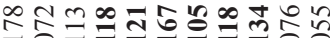

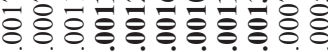
00000000000

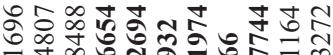

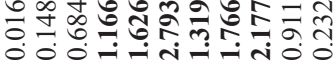

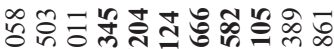

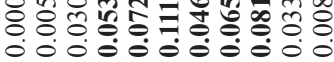

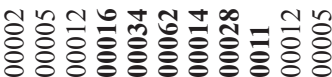

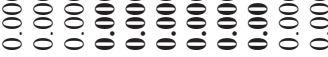

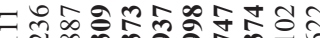

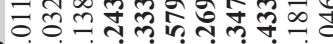
戠 000 영

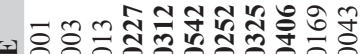

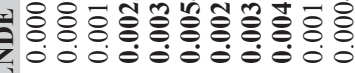

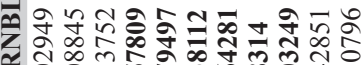
잉 के กิ 人. n⿴囗十

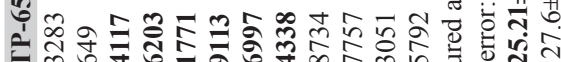
.

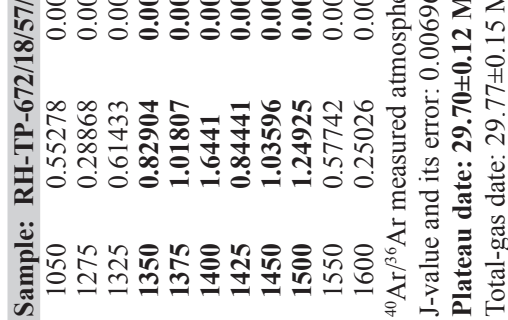




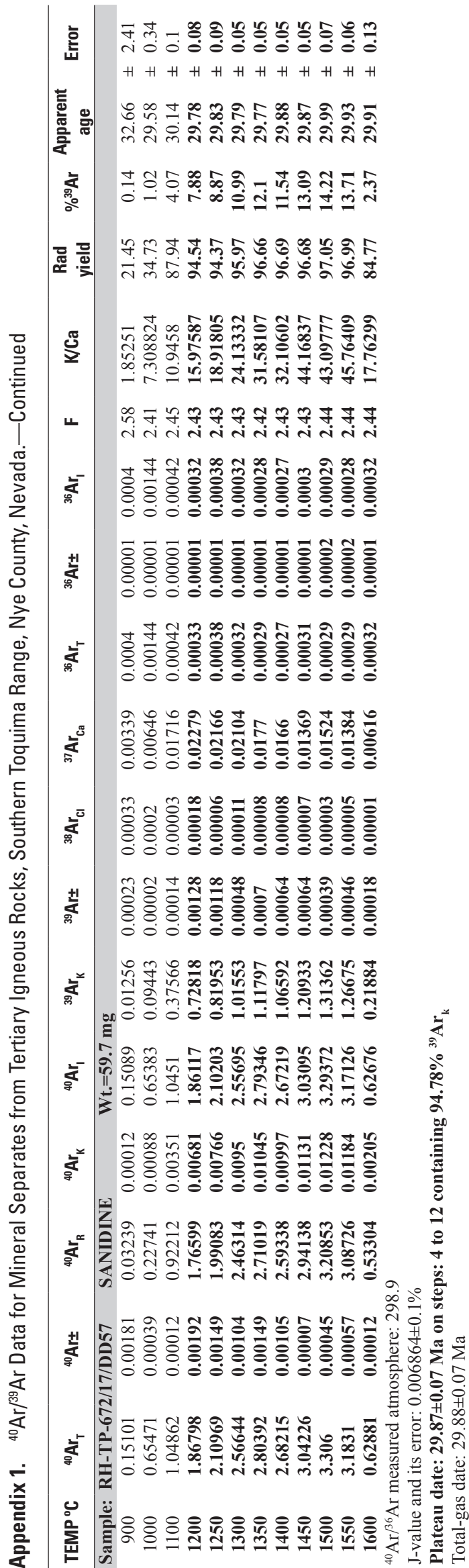

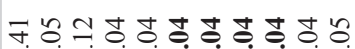

$-0.000000000$

$\mathrm{H} H \mathrm{H} H \mathrm{H} H \mathrm{H} H \mathrm{H} H \mathrm{H}$

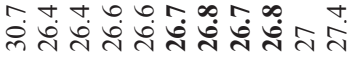

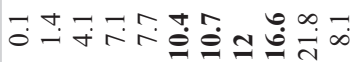

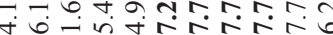

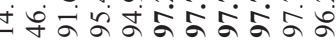

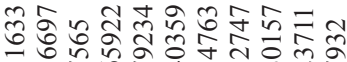

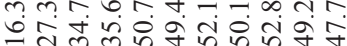

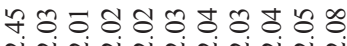
NT-n n n

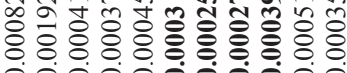
ठิ

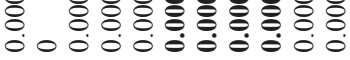

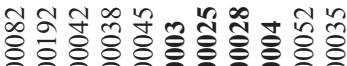

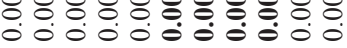

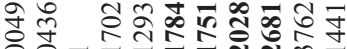

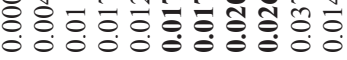

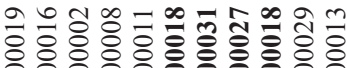

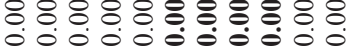
ธิ तิ

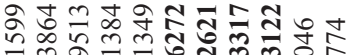

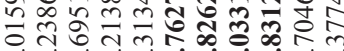
$\infty 0^{\circ}$ $\exists$

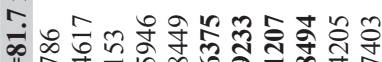

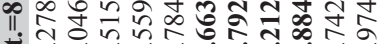

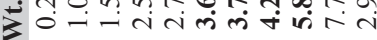

ำ สิ่

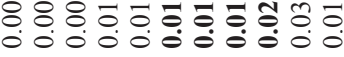
됮

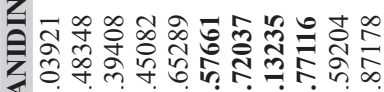

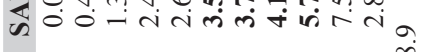

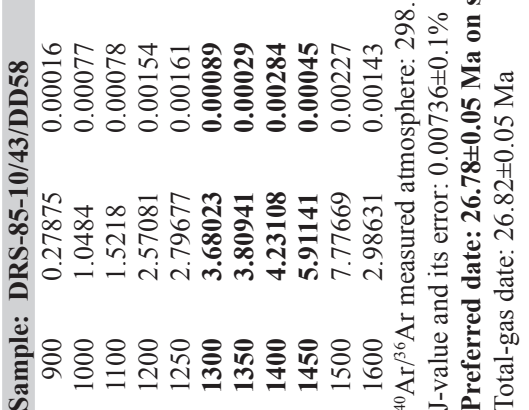

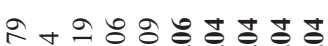

0000000000

$\mathrm{H} H+\mathrm{H} H+\mathrm{H} H+\mathrm{H}$

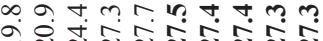

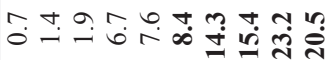

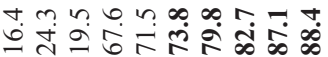

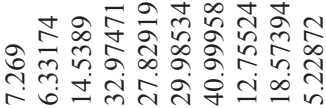

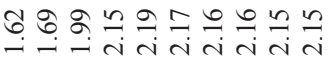

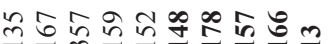

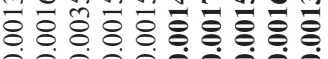

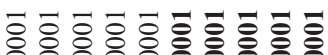

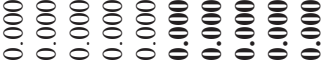

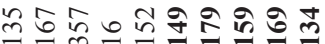

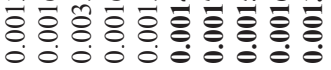

సิ

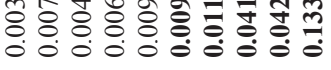

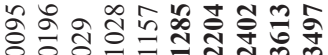

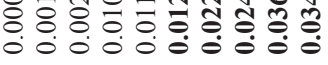

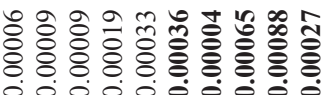

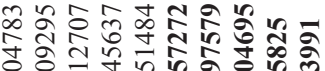

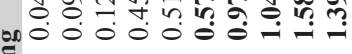
曾

के

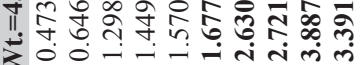

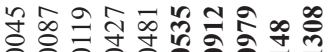

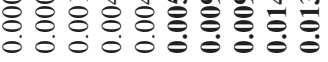

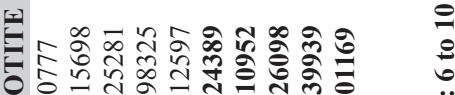

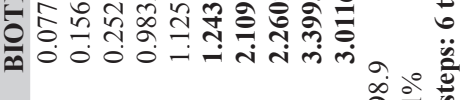

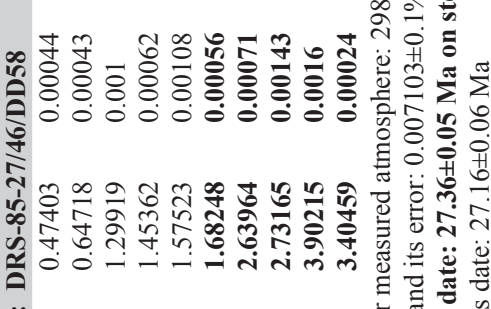

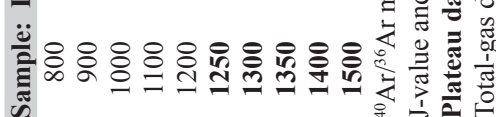




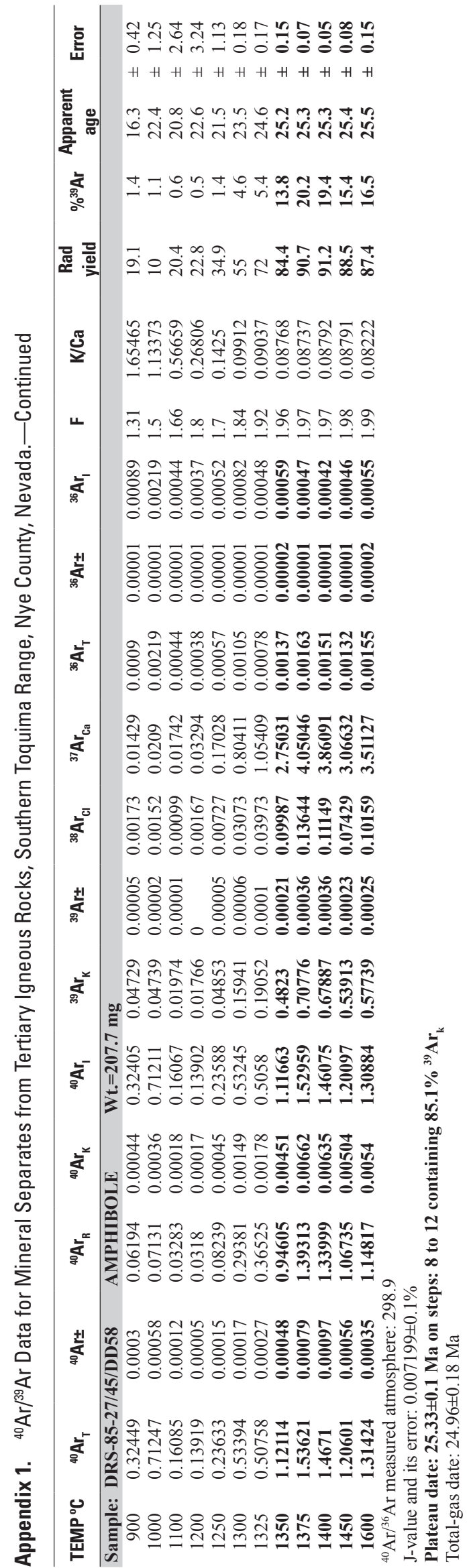

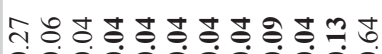

$\dot{\theta} \dot{\theta} \dot{\theta} \dot{\theta} \dot{0}$

$\mathrm{H}+\mathrm{H} H+\mathrm{H}+\mathrm{H}+\mathrm{H}+\mathrm{H}+\mathrm{H}$

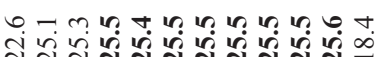

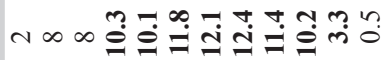

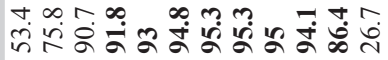

ธิळ

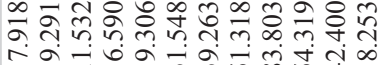

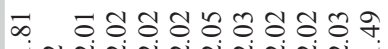

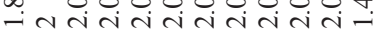

ナ तิ

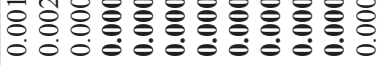

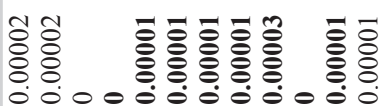

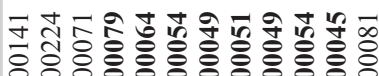

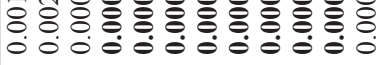

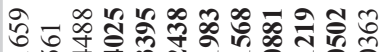

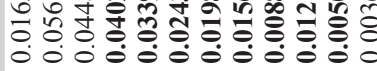

令获

ôे

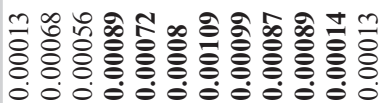

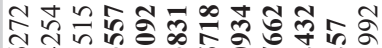

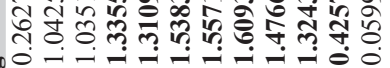

טno

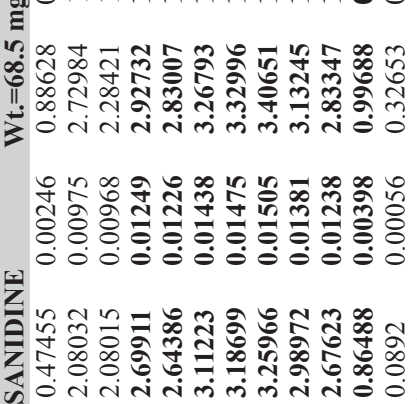

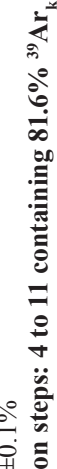

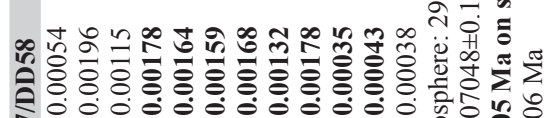

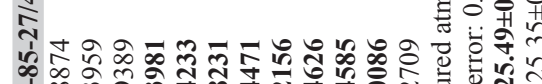

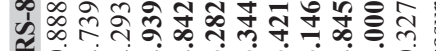

औ०त

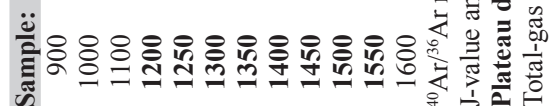

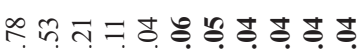

- $\dot{0} 0 \dot{0} 0 \dot{0} \dot{0} \dot{0} \dot{0} \dot{0} \dot{0}$

$\mathrm{H} H \mathrm{H} H \mathrm{H} H \mathrm{H} H \mathrm{H} H \mathrm{H}$

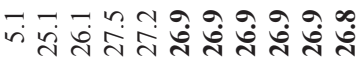

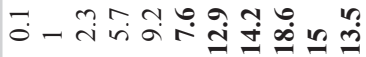

茫

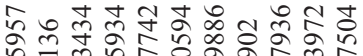

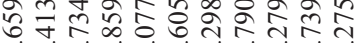
- ن

ํำำำำ드는

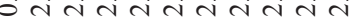

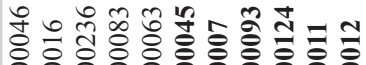

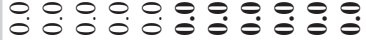

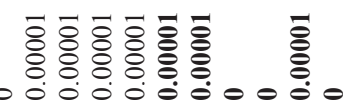

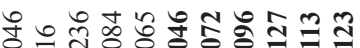
o.

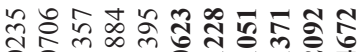

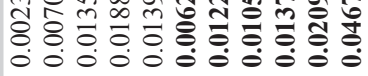

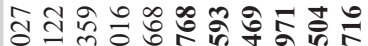

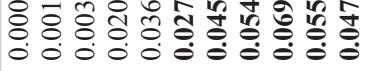

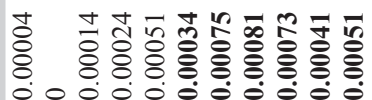

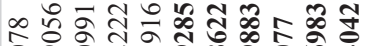

ठㅇํㅇํ तิ , 00

ภำ

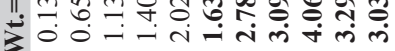

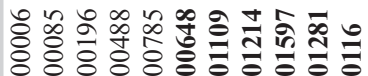

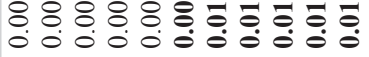

돈

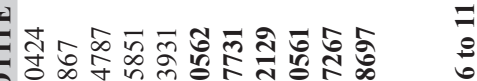

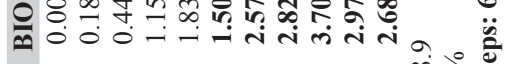

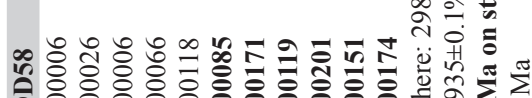

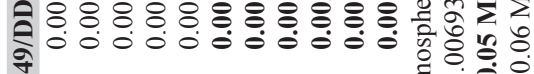

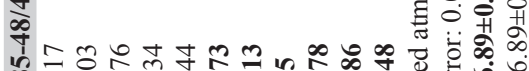
బ

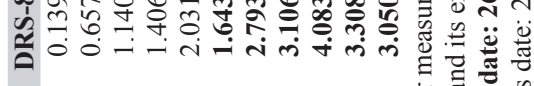

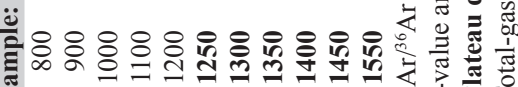




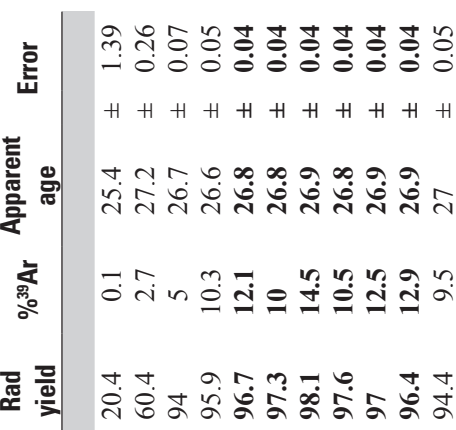

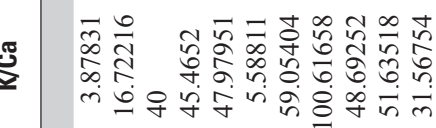

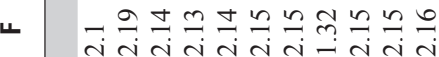

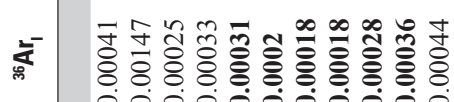

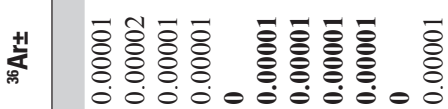

$\sum^{\infty}$

政

.

.

c

峁

高

奇

:

일

(a)

c

غ

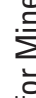

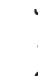

这

高

㐫

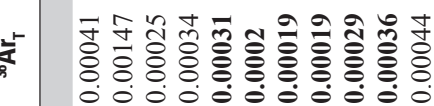

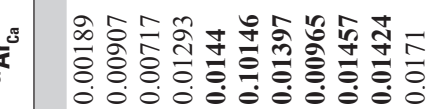

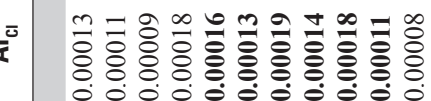

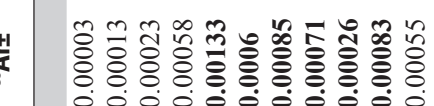

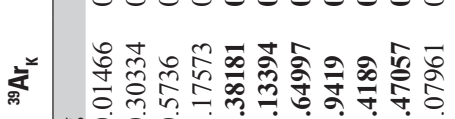

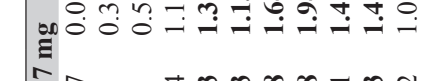

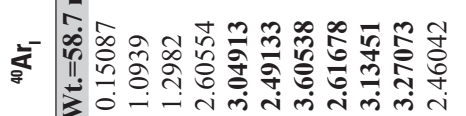

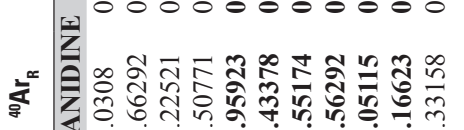

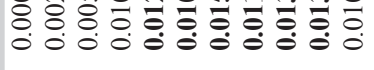

$\sqrt[3]{2}$

की

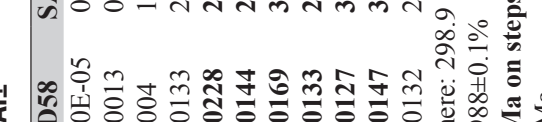

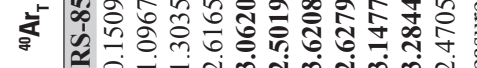

(1)

玄

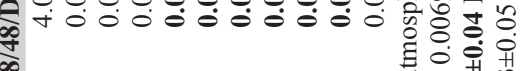

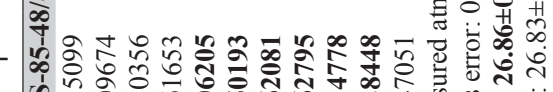

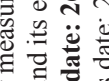

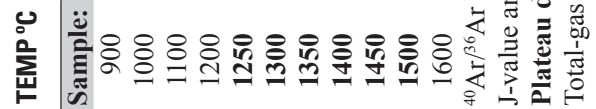

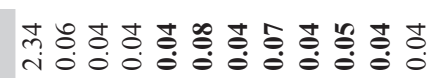

$\mathrm{H} H \mathrm{H} H \mathrm{H} H \mathrm{H} H \mathrm{H} H \mathrm{H} H$

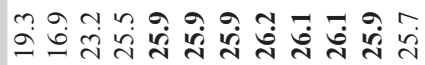

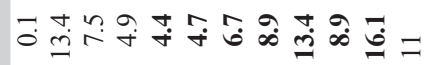

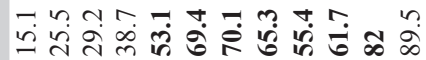

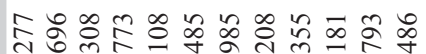

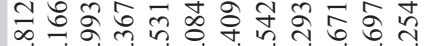

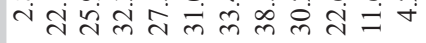

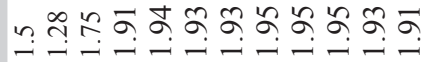

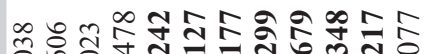

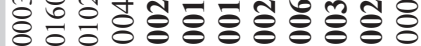

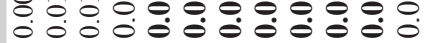

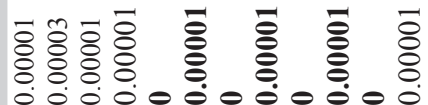

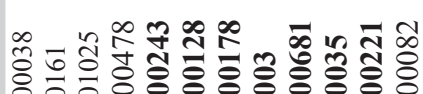

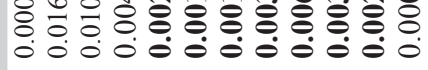

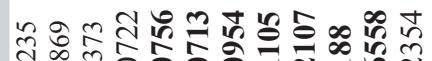

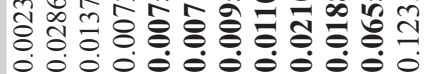

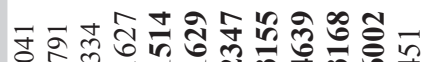

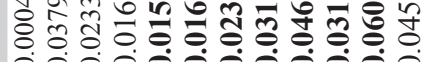

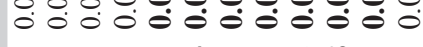

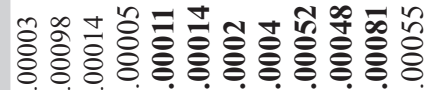

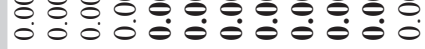

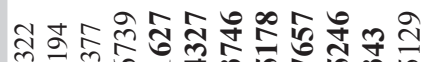

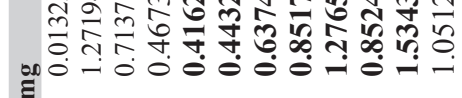

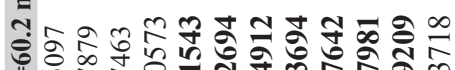

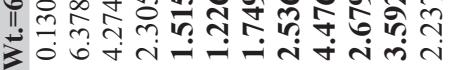

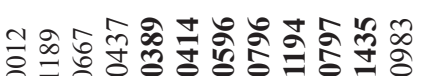

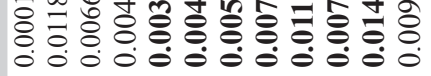

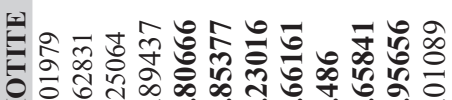

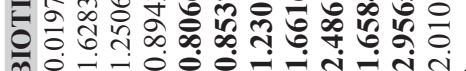

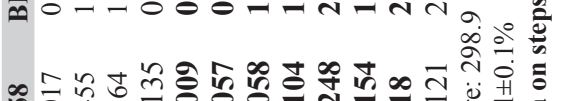

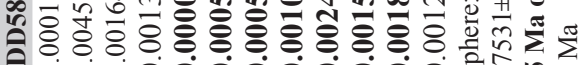

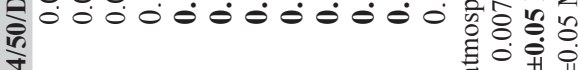

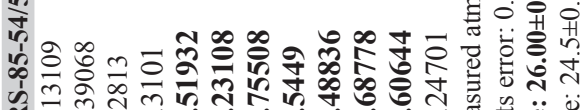

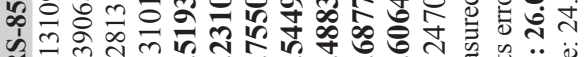

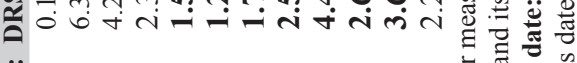

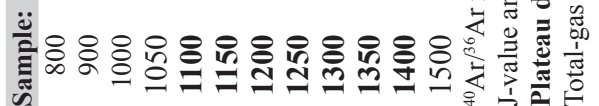

ॠ

H H H H H H H H H H

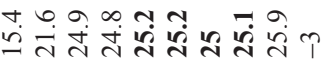

ดें

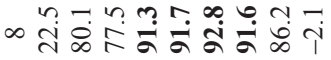

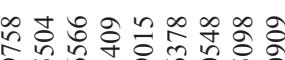

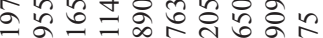

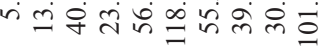

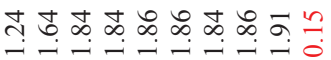

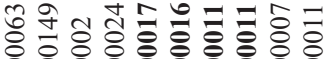

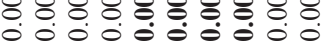

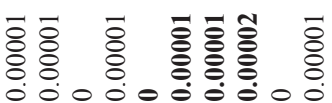

잉

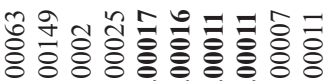

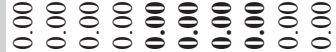

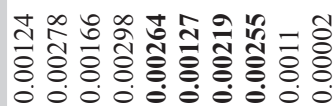

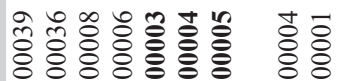

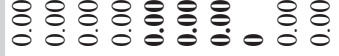

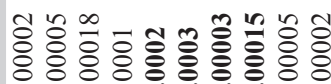

00000000.

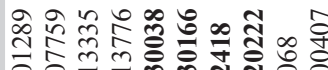



$\exists$

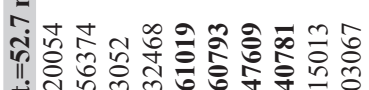

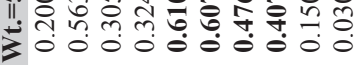

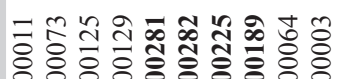

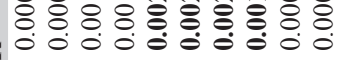

论瓷

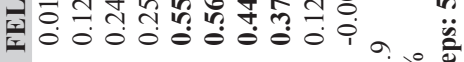

तेำ

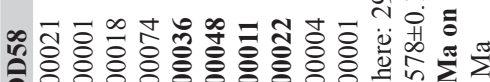

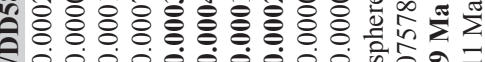

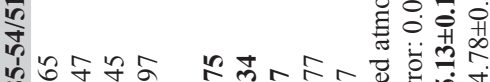

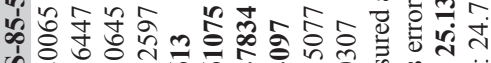

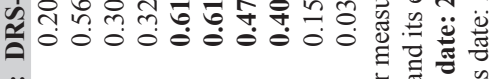

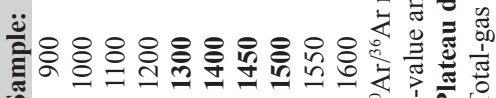



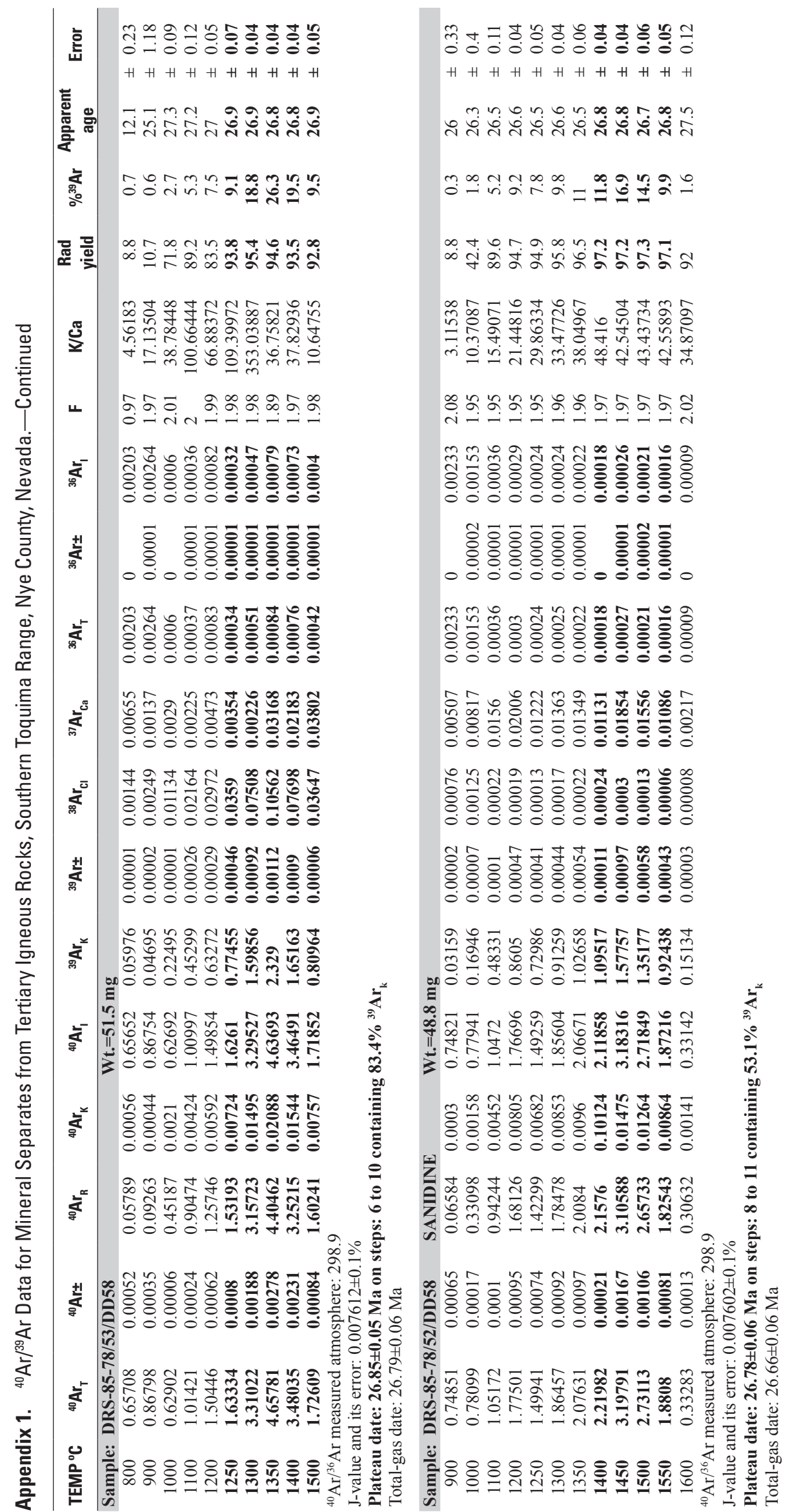

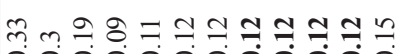
$\mathrm{H} H \mathrm{H} H \mathrm{H} H \mathrm{H}+\mathrm{H} H \mathrm{H} H$

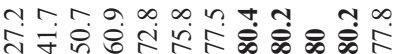

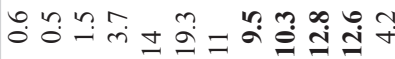

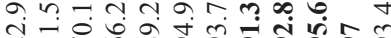

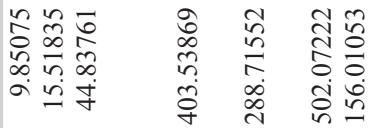

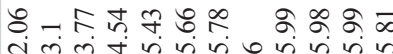

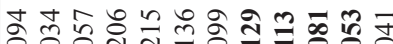
○. \&

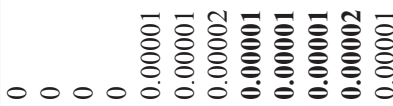

ษับํำ

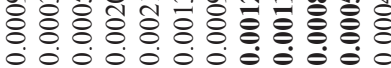

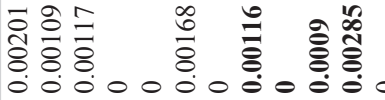

đ广t -

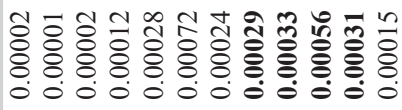

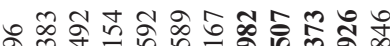
के

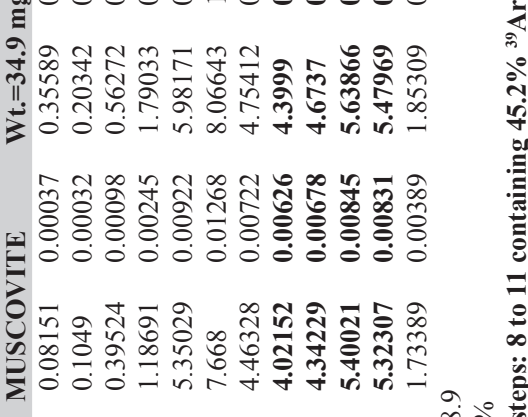

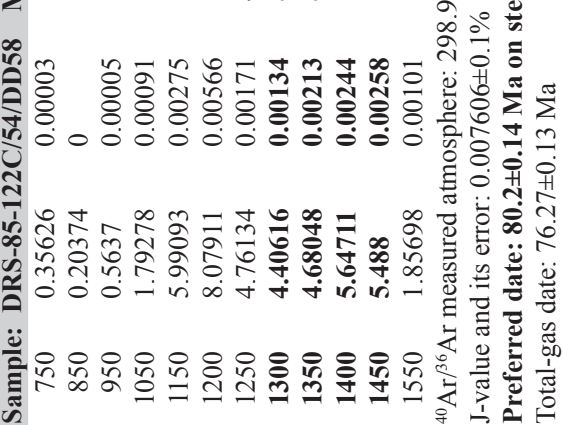




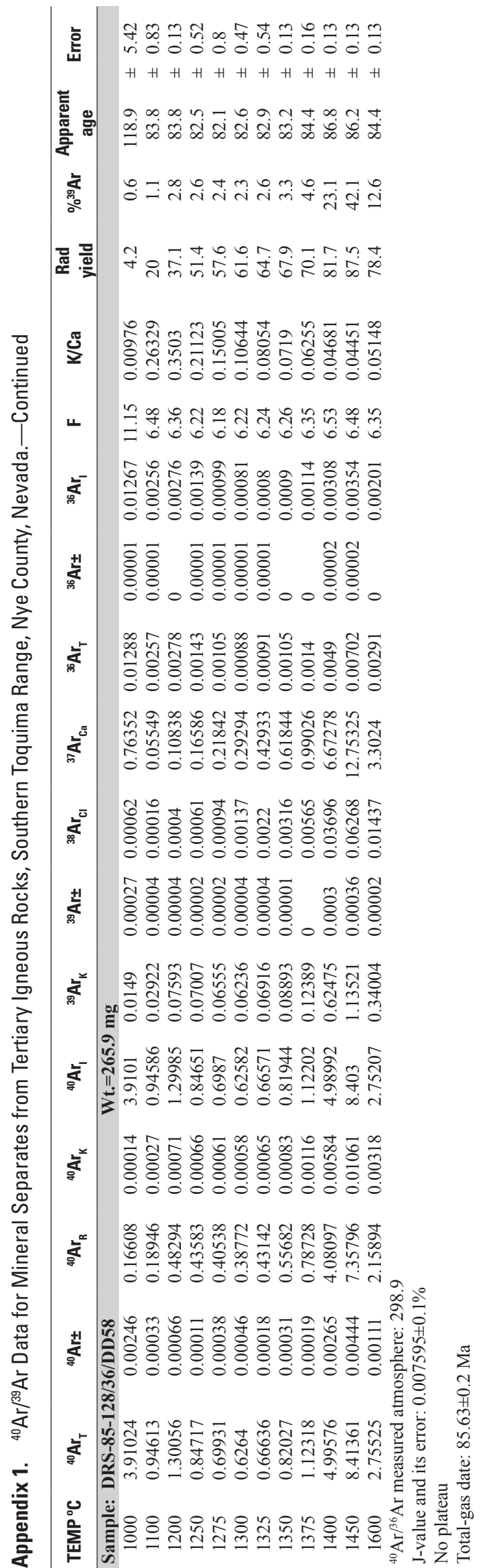

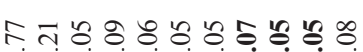

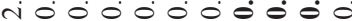

$\mathrm{H} H \mathrm{H} H \mathrm{H} H \mathrm{H} H \mathrm{H} H \mathrm{H}$

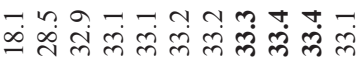

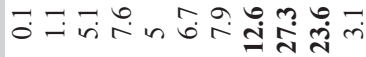

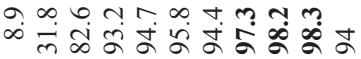

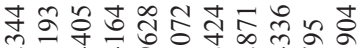

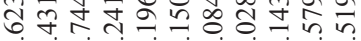

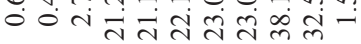

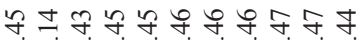

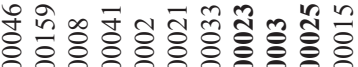
0000000000

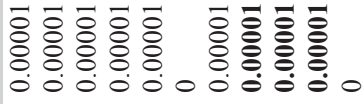

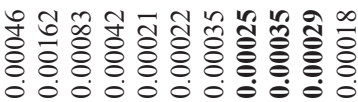

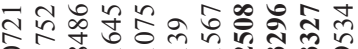

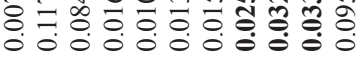

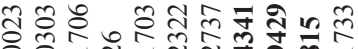

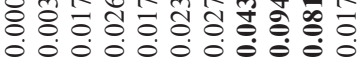

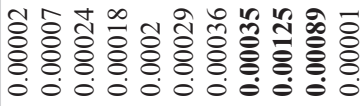

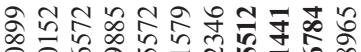

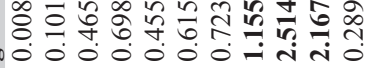

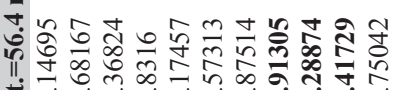

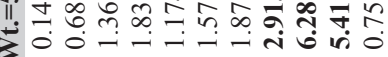

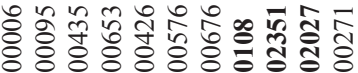

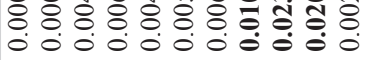

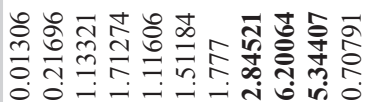

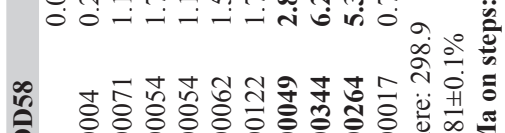

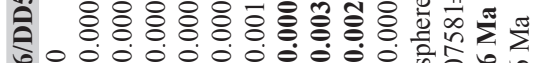

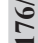

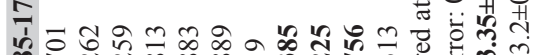
$\infty$ 엉

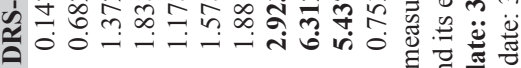

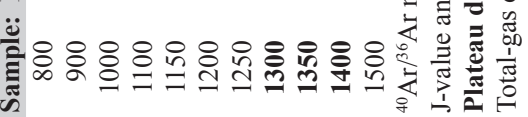

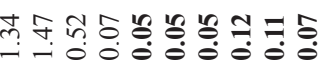

$\mathrm{H} H \mathrm{HH} H \mathrm{H} H \mathrm{H} H \mathrm{H}$

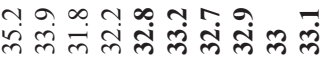

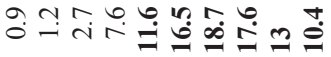

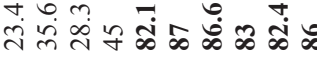

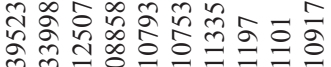

ले

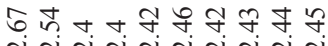

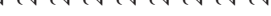

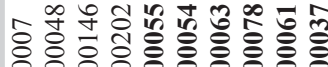
$\therefore 00000000$

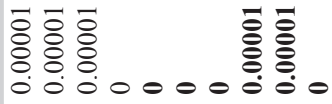

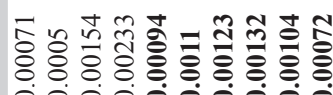
(5)

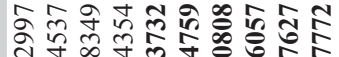

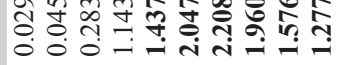

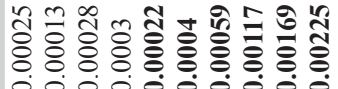

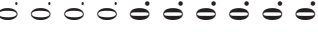

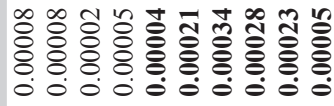

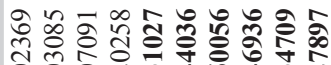

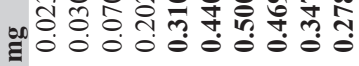

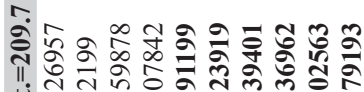

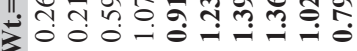

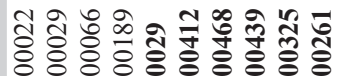

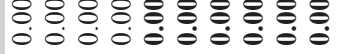

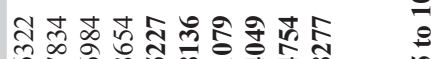

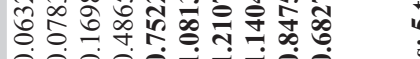

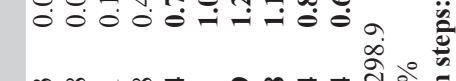

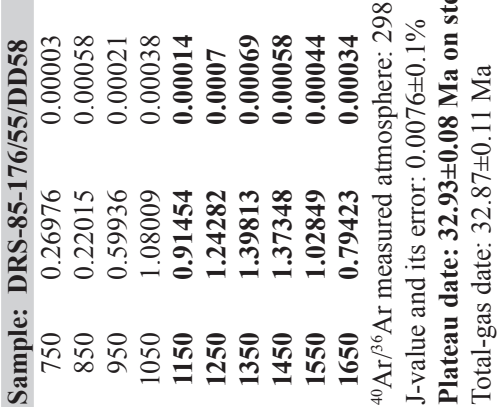




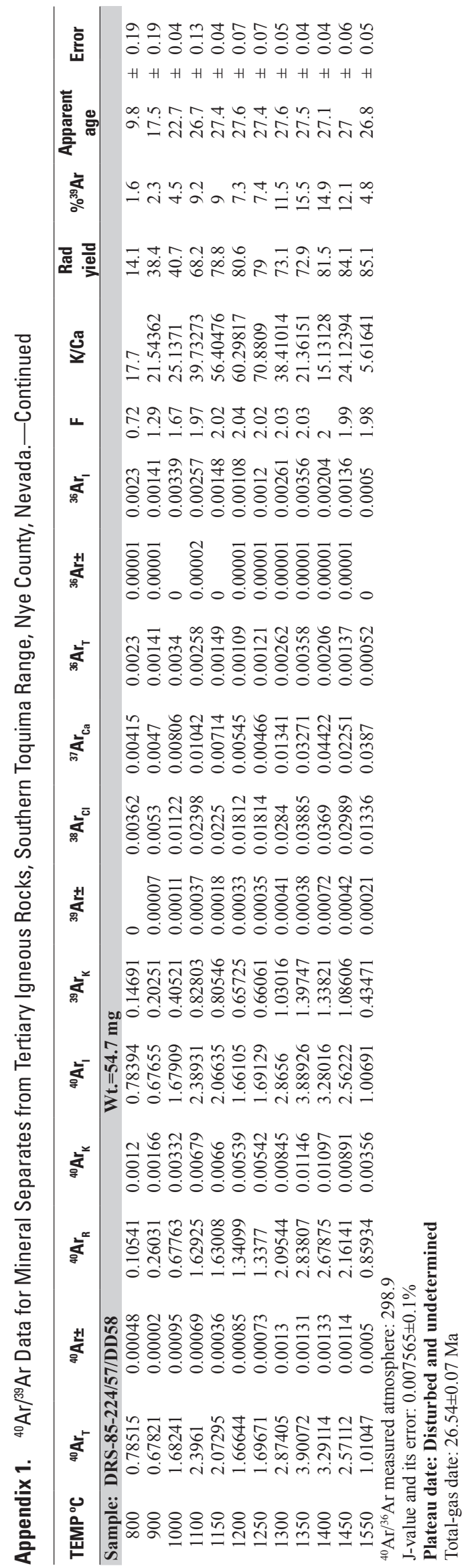

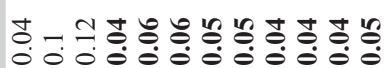

$H+H+H+H+H+H+H$

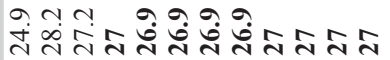

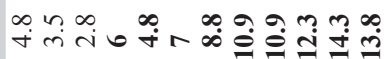

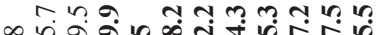

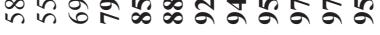

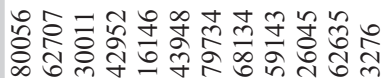

○ें

$\circ \approx \tilde{\sigma} \sigma$

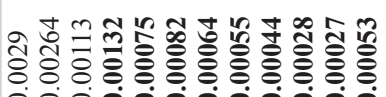

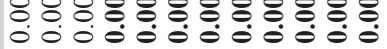

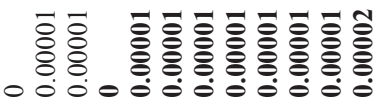

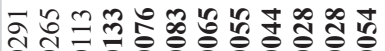

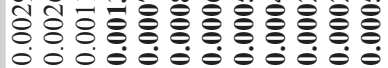

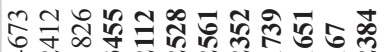

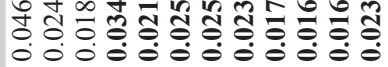

นิ

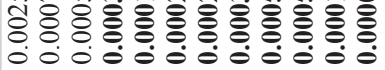

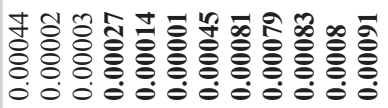

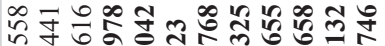

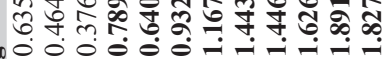

$\stackrel{200}{30}$

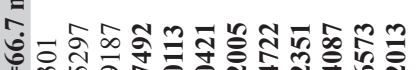

\%

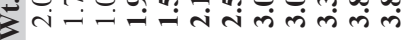

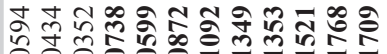

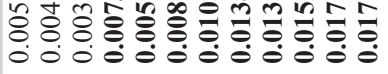

단

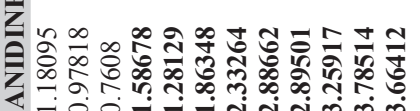

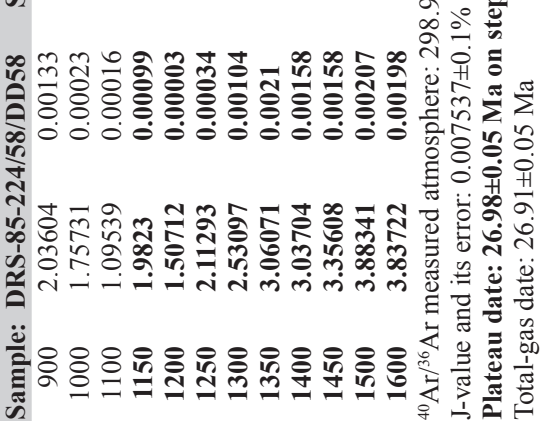

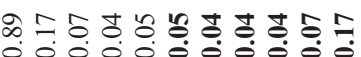

$\mathrm{H} H+\mathrm{H} H+\mathrm{H}+\mathrm{H}+\mathrm{H}$

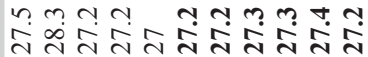

乌ి

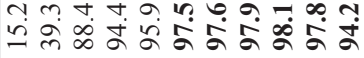

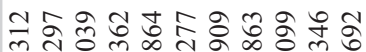

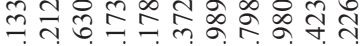

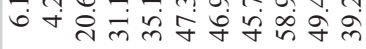

t

4i i i i i i i i i i

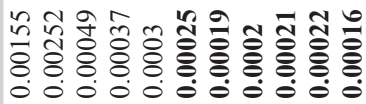

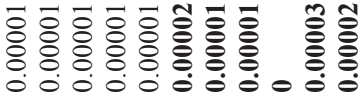

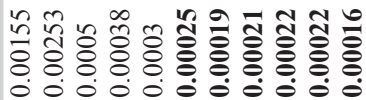

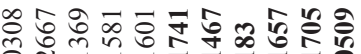

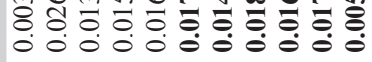

సิ

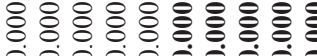

- 00000000

ธิ้

1000000

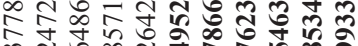

ชิ

${ }_{20}^{\circ}$

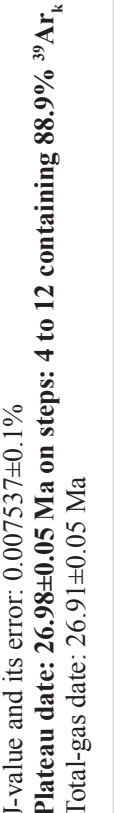




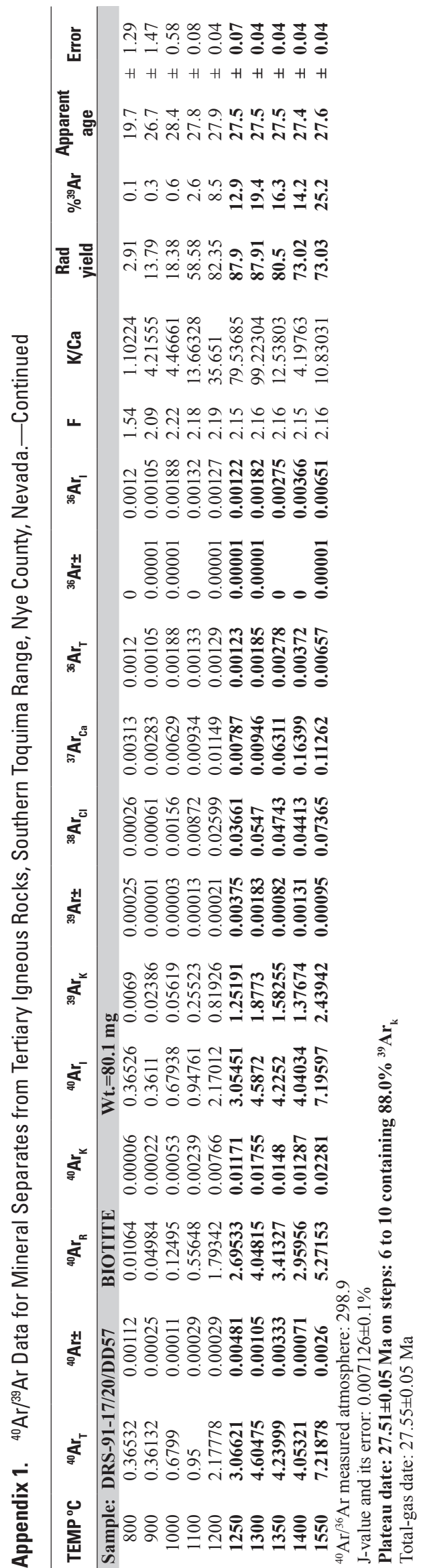

๗ઇ

0 म

$\mathrm{H}+\mathrm{H} H \mathrm{H} H \mathrm{H} H \mathrm{H}+\mathrm{H}+\mathrm{H} H$

o.

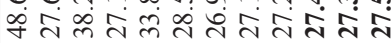

ڤุo

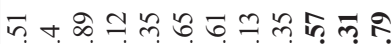

म

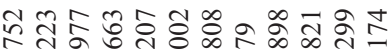

ले

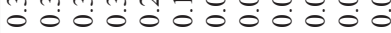

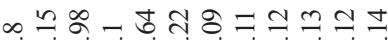

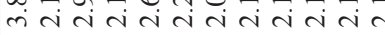

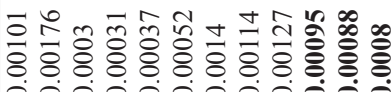
00000000000

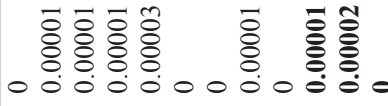

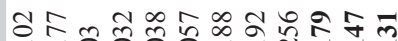

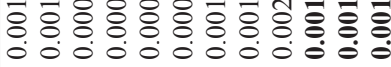

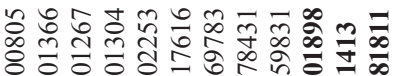

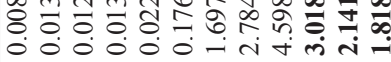

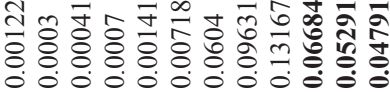

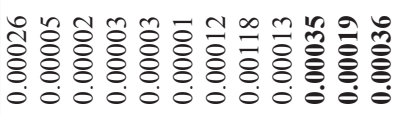

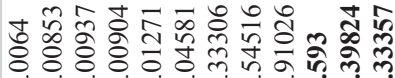

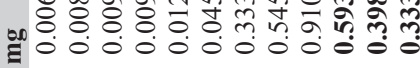

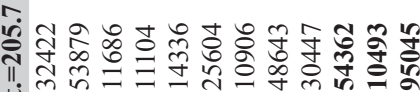

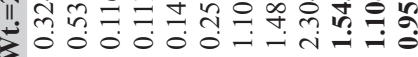

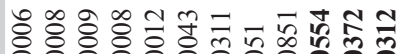

州 ○

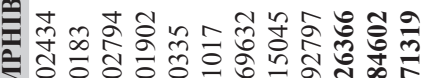

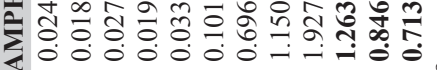

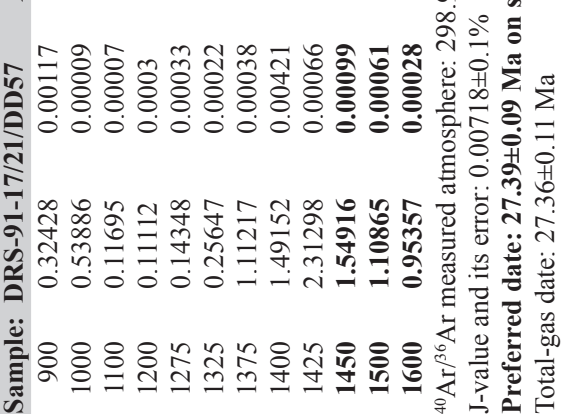

ที่

= $0 \dot{0} 0 \dot{0} 0 \dot{0} 0 \dot{0} 0 \dot{0} 0$

$\mathrm{H} H \mathrm{H} H \mathrm{H} H \mathrm{H} H \mathrm{H} H \mathrm{H} H$

n⿻

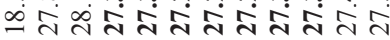

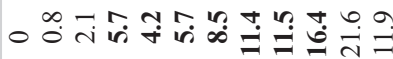

ํำ ๆ

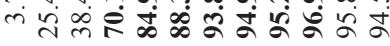

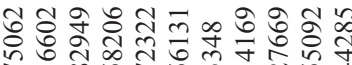
ऊूं

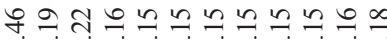

๙ิ๊

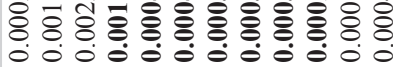

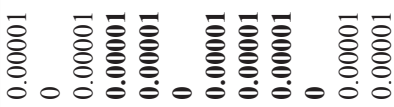

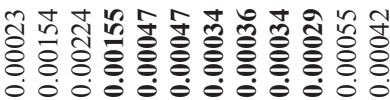

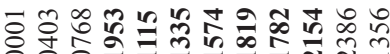

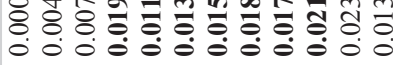

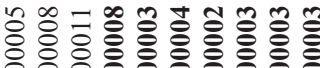

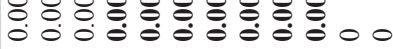
농

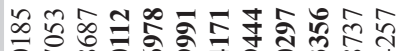

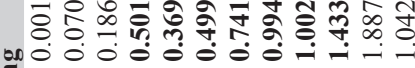

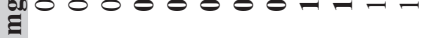

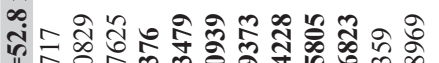

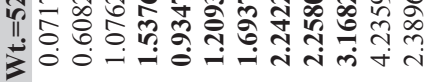

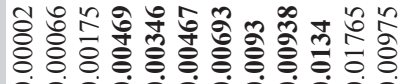
단 (r)

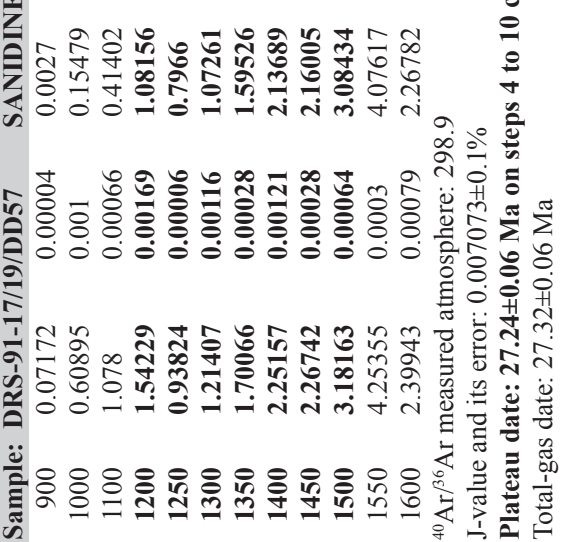



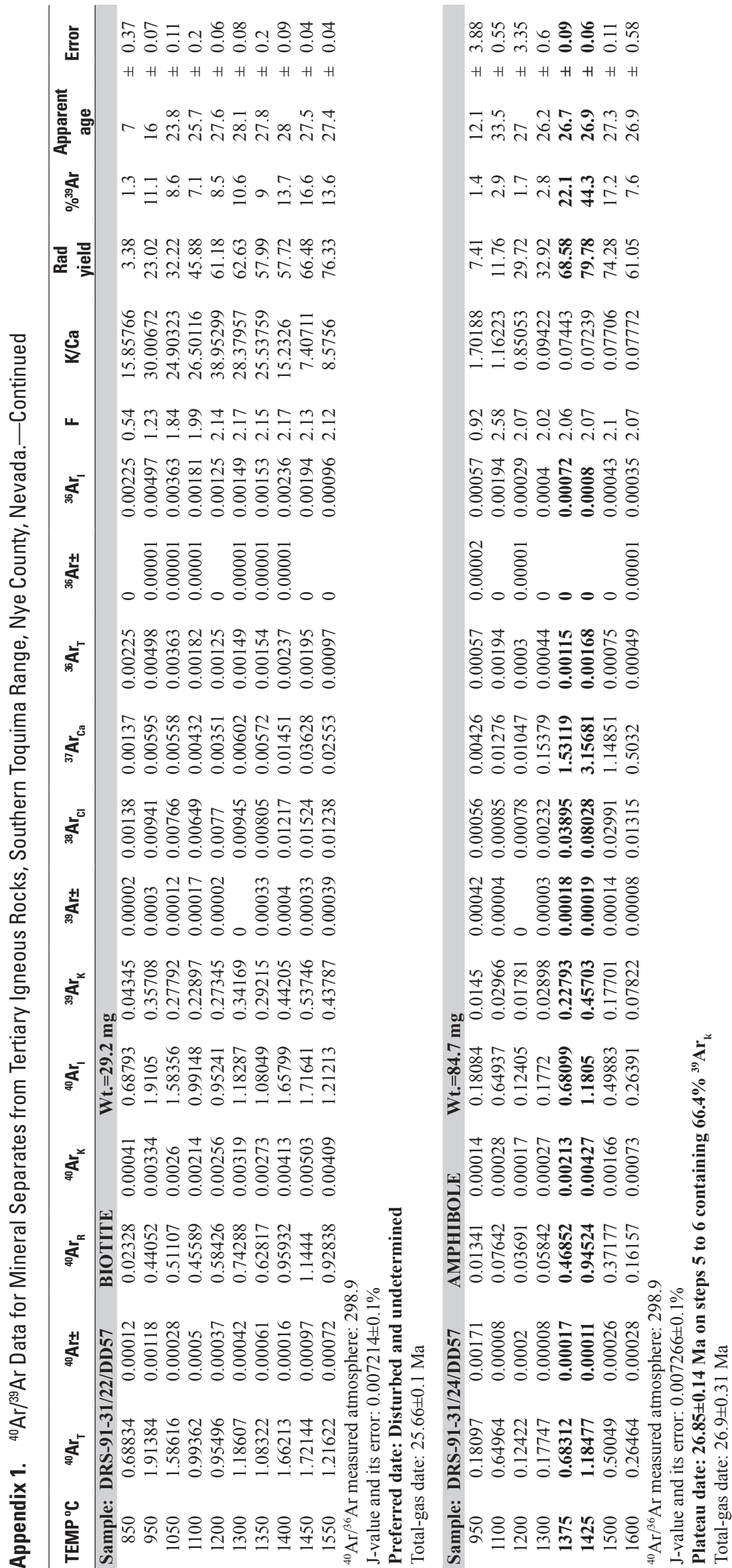

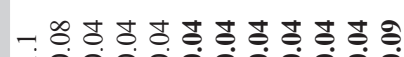
0
0 $\mathrm{H} H \mathrm{H} H \mathrm{H} H \mathrm{H} H \mathrm{H} H \mathrm{H} H$

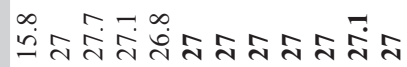

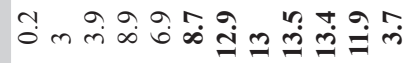

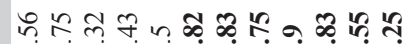

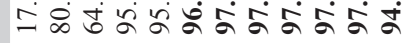

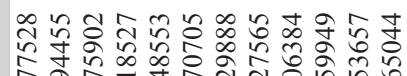

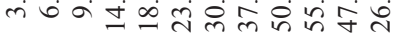

สุ Nतindind

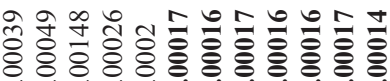
$\circ 0000000000$ हैं

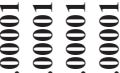

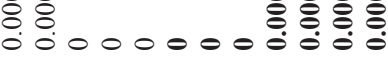

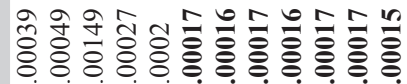

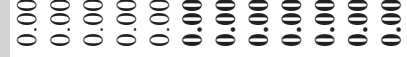

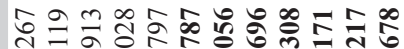

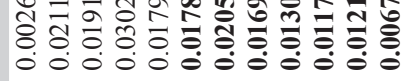

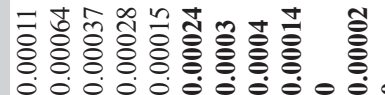
तิ

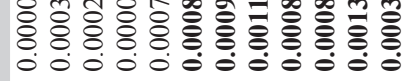

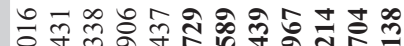

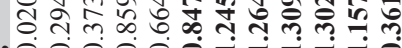

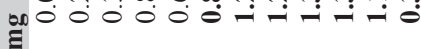

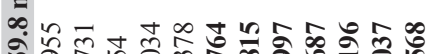

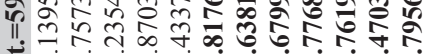

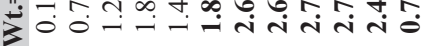

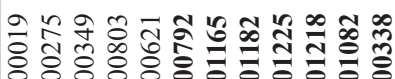

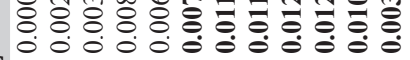
단

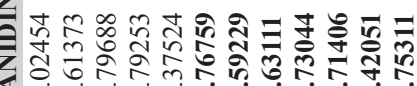

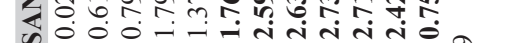
ก

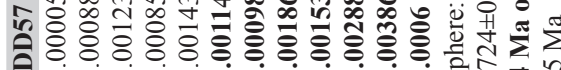
ल000000000000

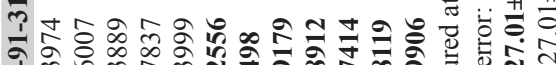
मे

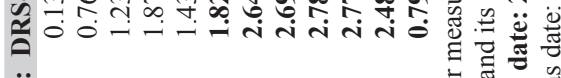

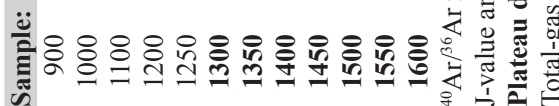




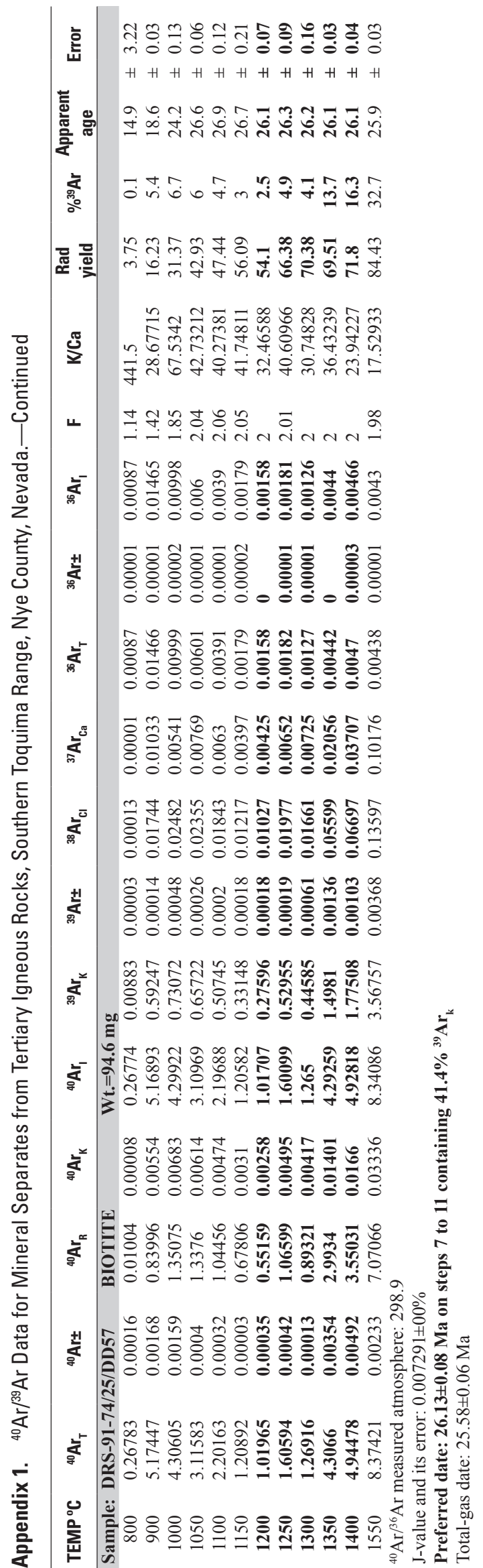

ำ

$\mathrm{H} H \mathrm{H} H+\mathrm{H}+\mathrm{H}+\mathrm{H} H$

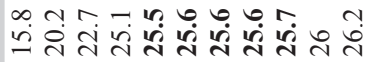

舟

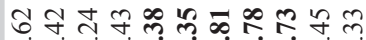

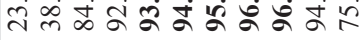

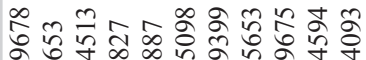

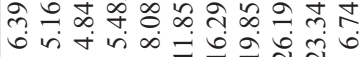

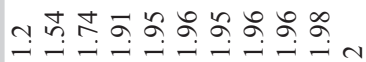

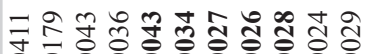

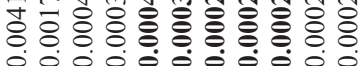

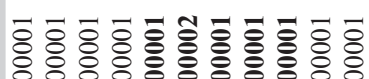

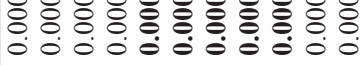

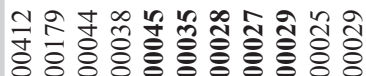

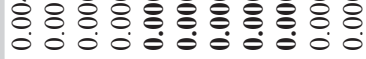

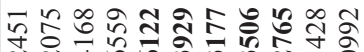

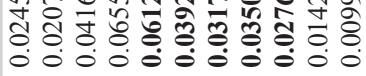

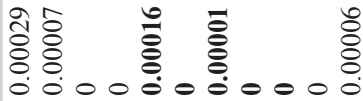

प艹

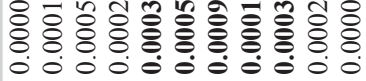

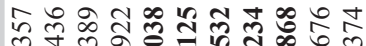

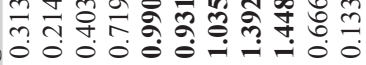

$\stackrel{200}{*}$

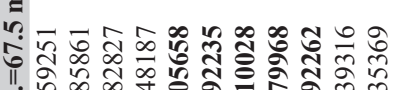

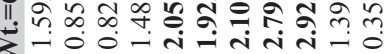

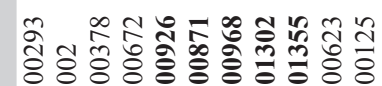
됙

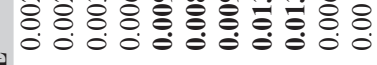

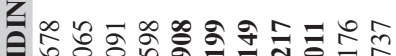

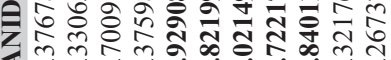

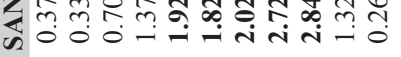

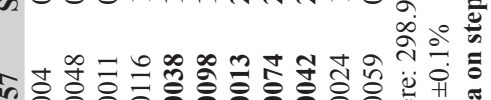

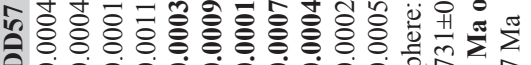

章

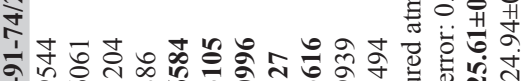

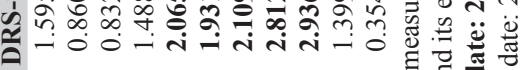

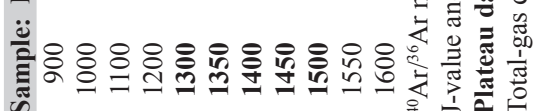

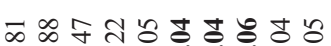

0000000000

$\mathrm{H}+\mathrm{H} H \mathrm{H}+\mathrm{H}+\mathrm{H} H$

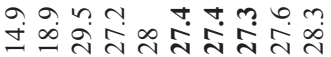

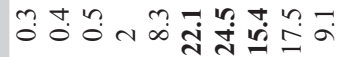

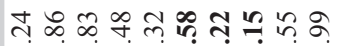

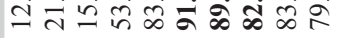

중 m

ते

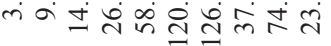

$\because$ 군

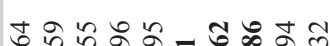

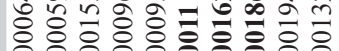

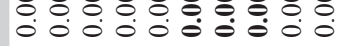

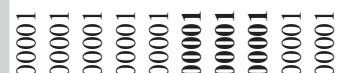

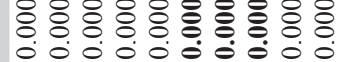

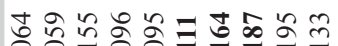

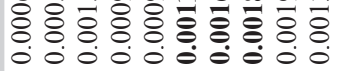

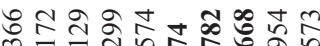

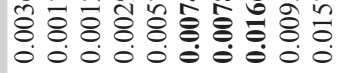

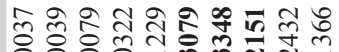

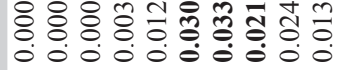

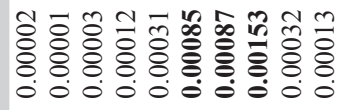

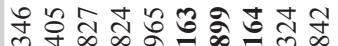

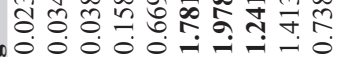

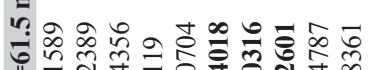

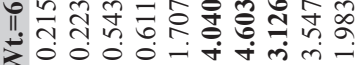

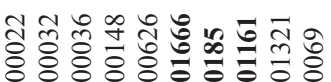
过

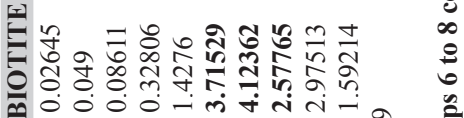

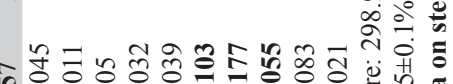

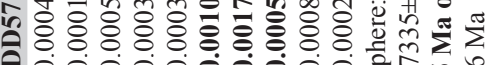

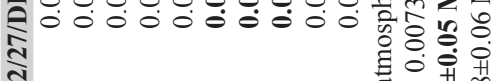

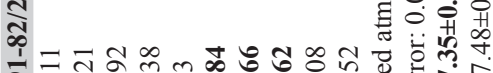

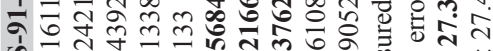

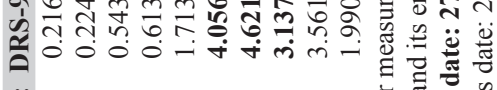

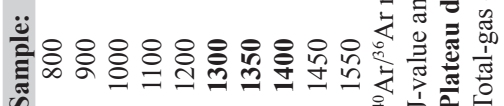



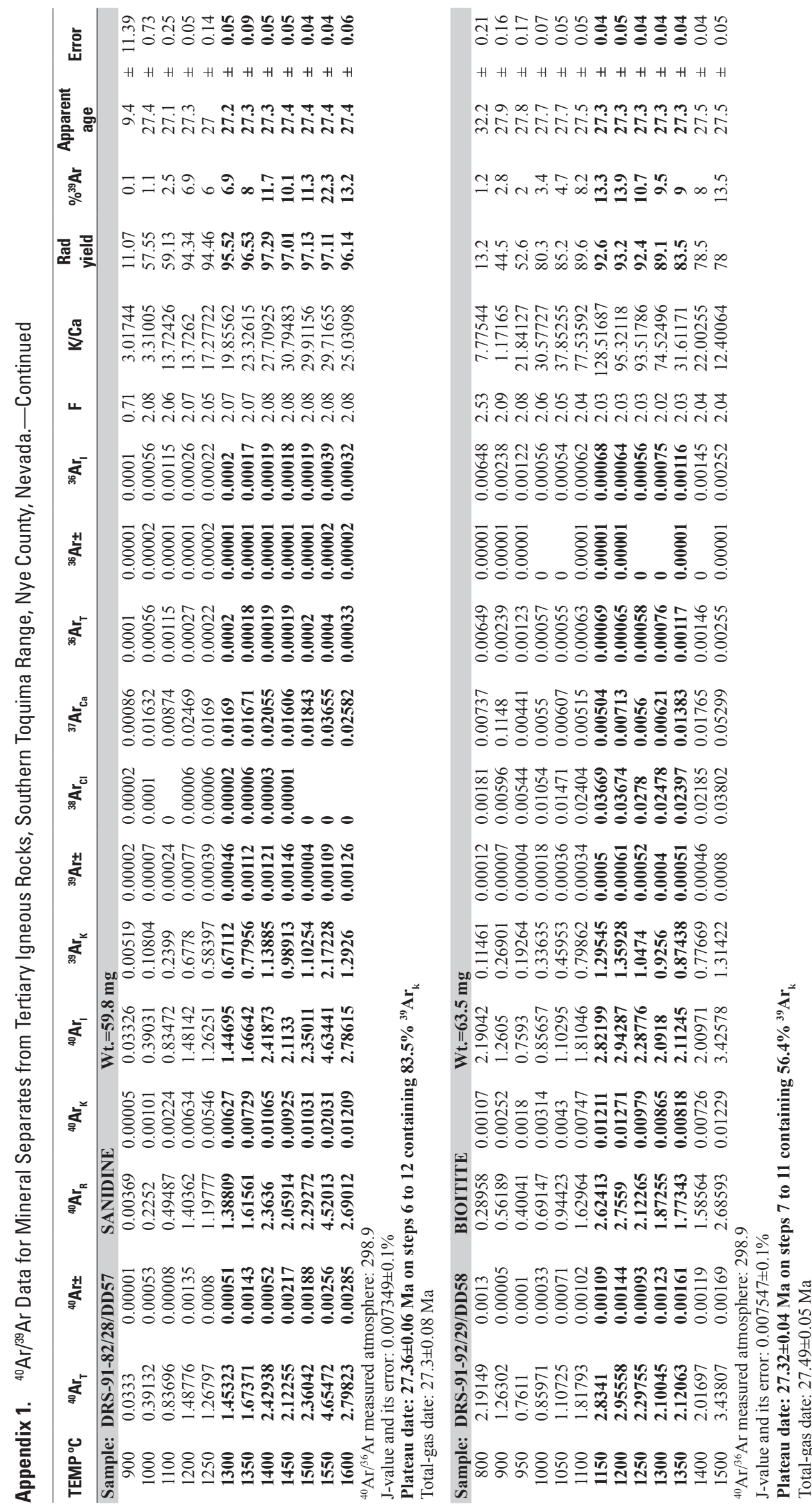

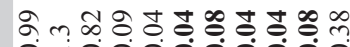
$0-0000000000$ $\mathrm{H} H+\mathrm{H} H+\mathrm{H}+\mathrm{H}+\mathrm{H}+\mathrm{H}$

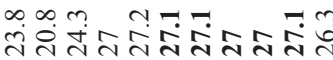

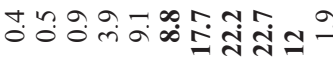

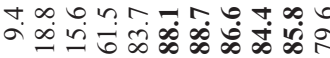

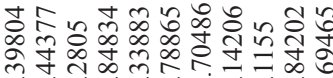

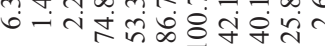

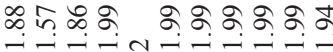

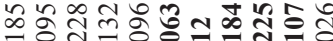

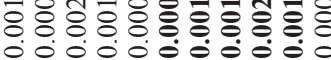

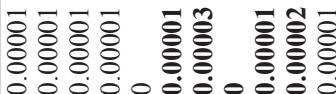
\%

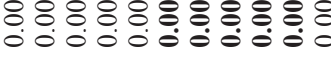

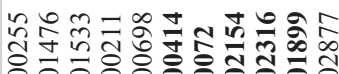
8.0.0.0.0.000

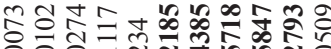

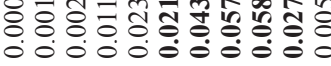

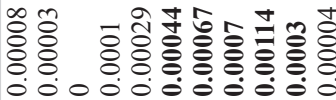

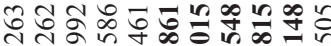
fos ט0

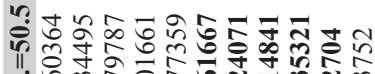

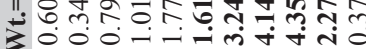

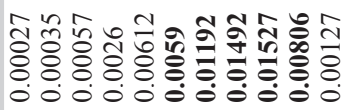
실

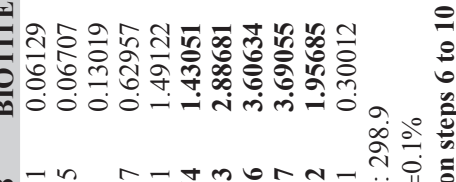

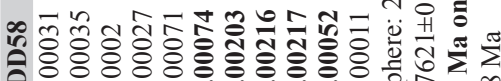
100000000000 象

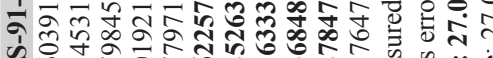
行0

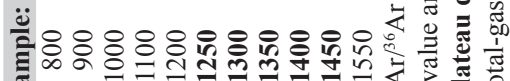




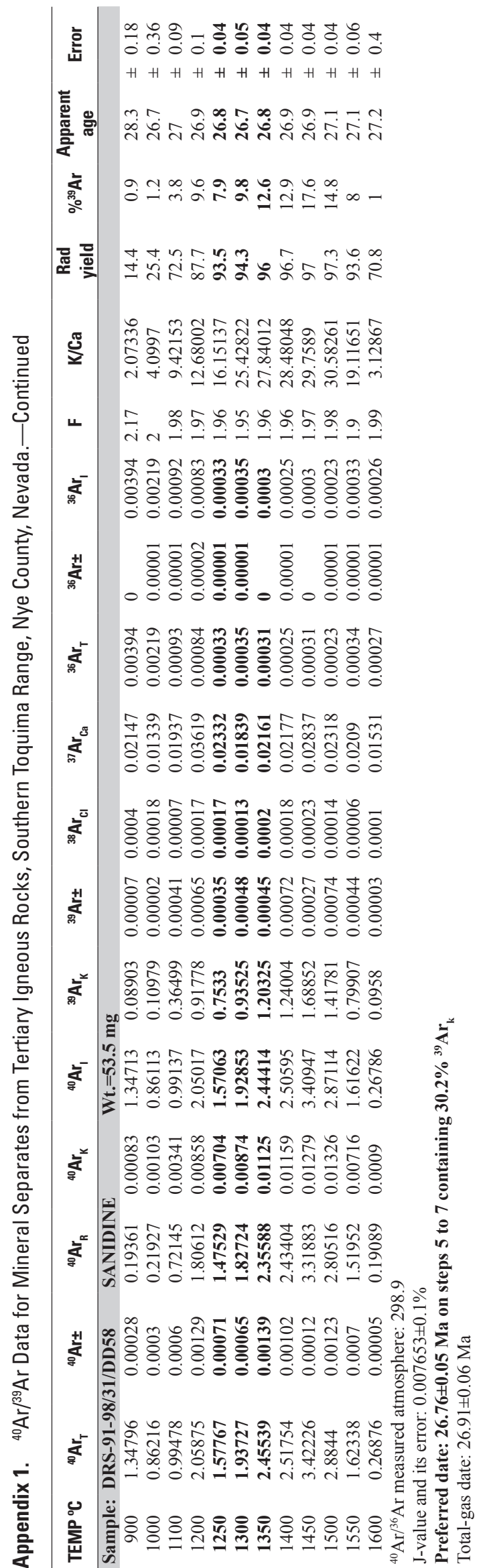

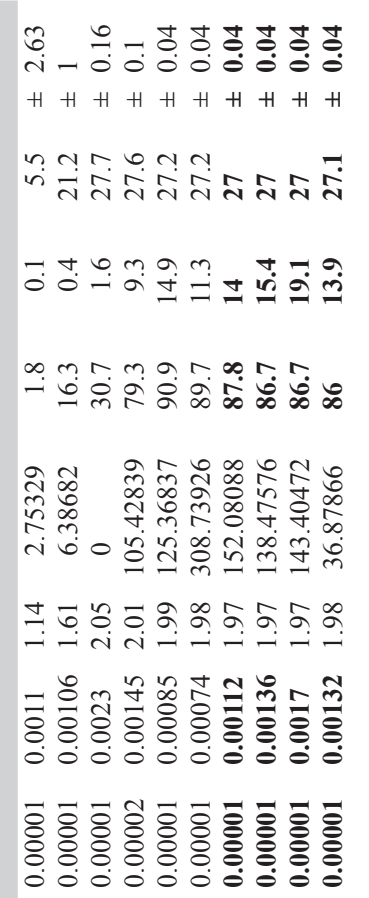

=동ำ

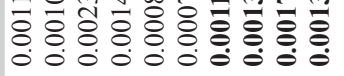

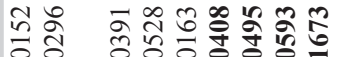

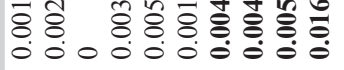

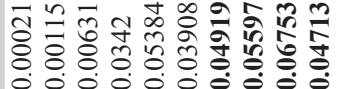
0000000000

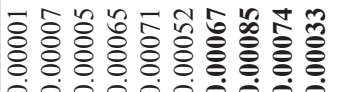
0.00000000

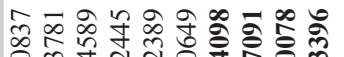

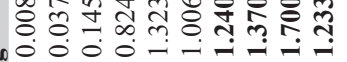
些

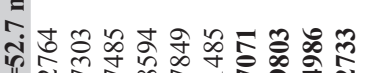

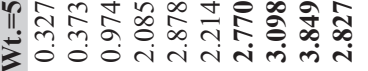

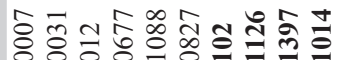

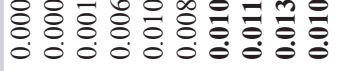

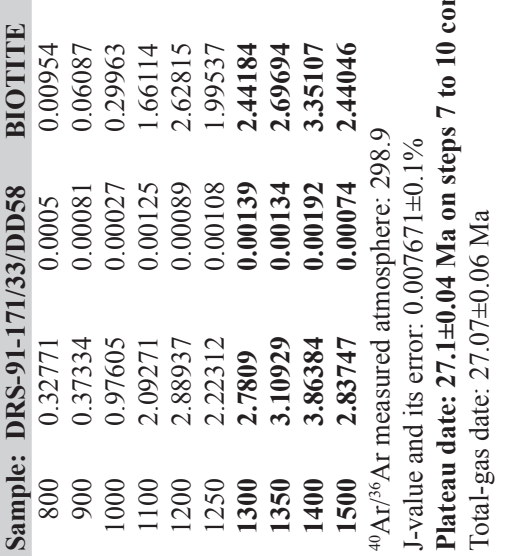

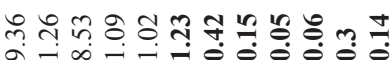
$\mathrm{H} H \mathrm{H} H \mathrm{H} H \mathrm{H} H \mathrm{H} H \mathrm{H} H$

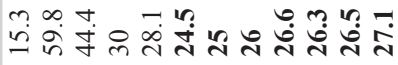
กุด่ भं भुં

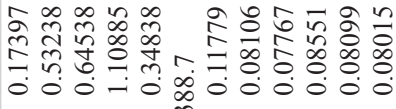

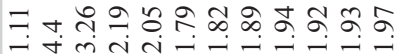

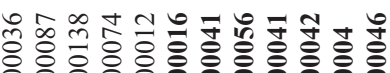

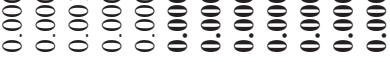

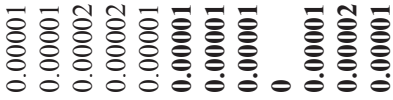

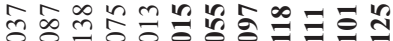

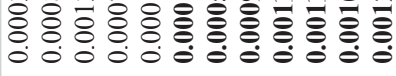

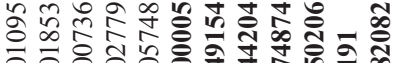

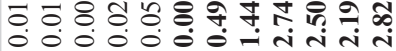

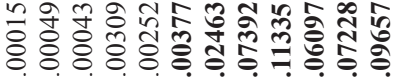
0.000000000

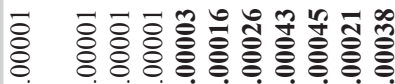
0000000000

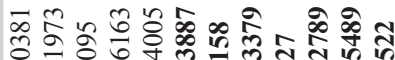
${ }_{00} \circ 00000000$

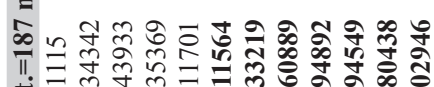

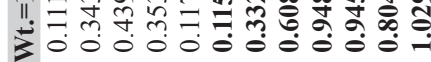

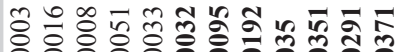

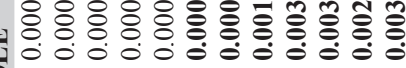

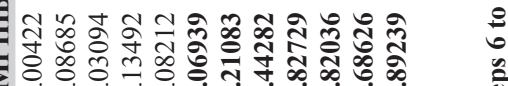

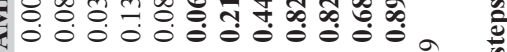

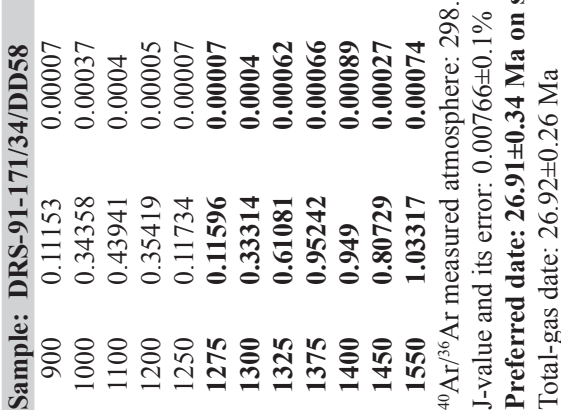




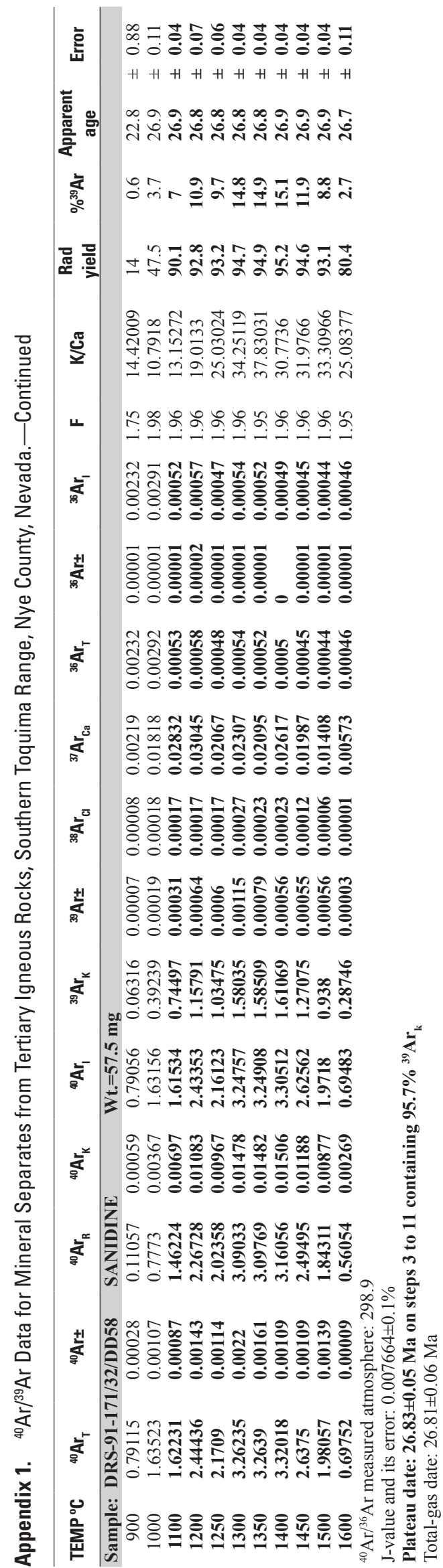

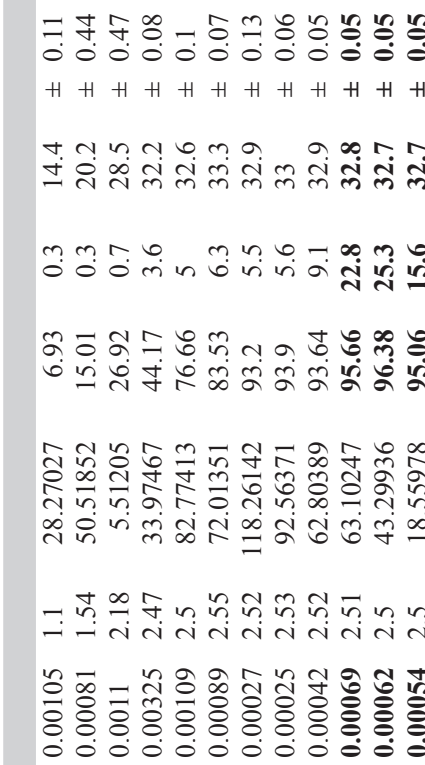

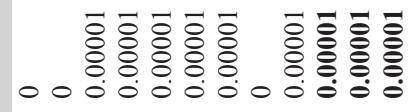

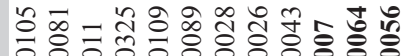

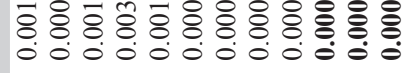

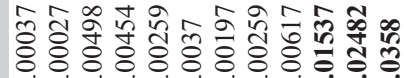
年

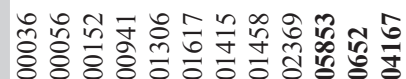

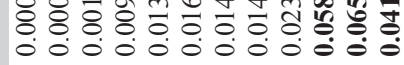

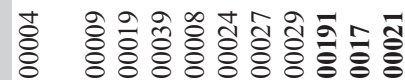

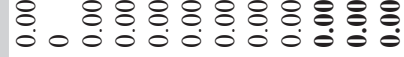

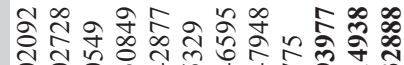

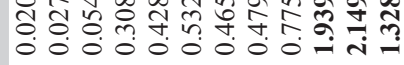
艎

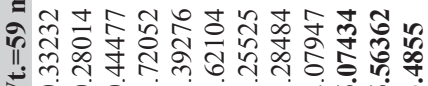

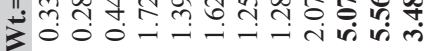

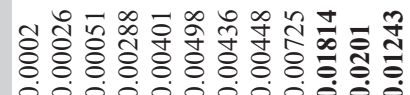

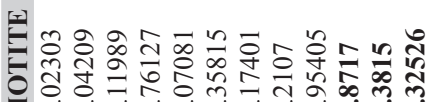

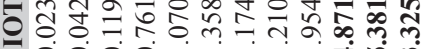
$\infty \infty m+\infty) \infty$ to

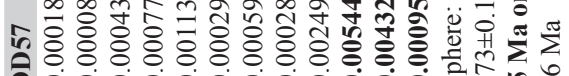

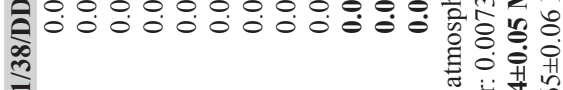
ฟี่

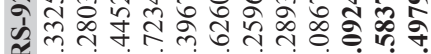

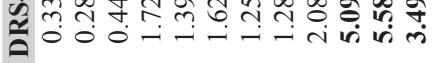
范各 \& ,

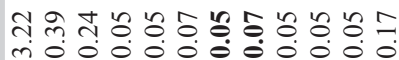
$\mathrm{H}+\mathrm{H} H \mathrm{H} H \mathrm{H} H \mathrm{H} H \mathrm{H} H$

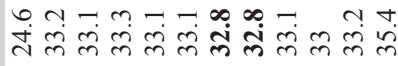

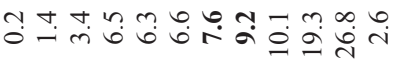

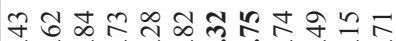

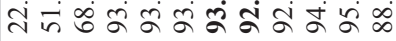

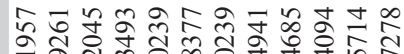

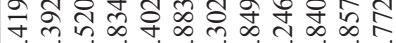

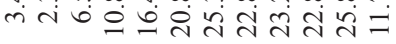

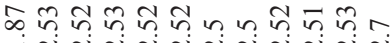

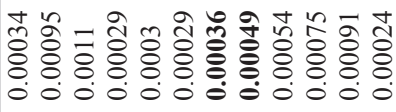

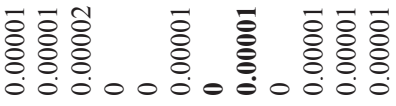

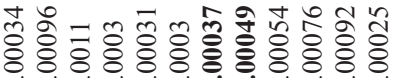

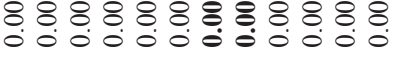

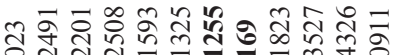

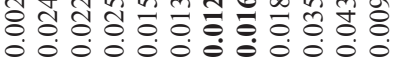

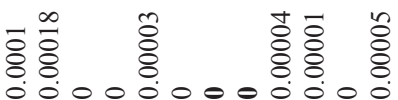

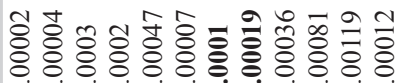

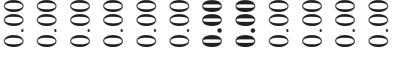

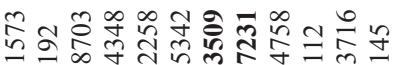

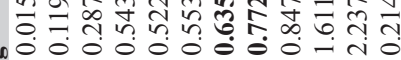
mo

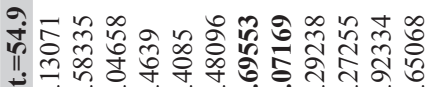

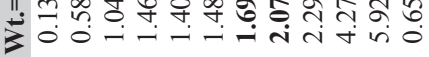

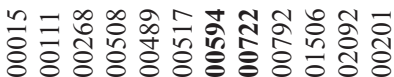
단

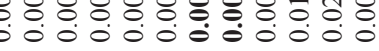

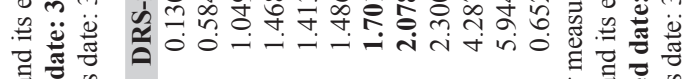
U. 


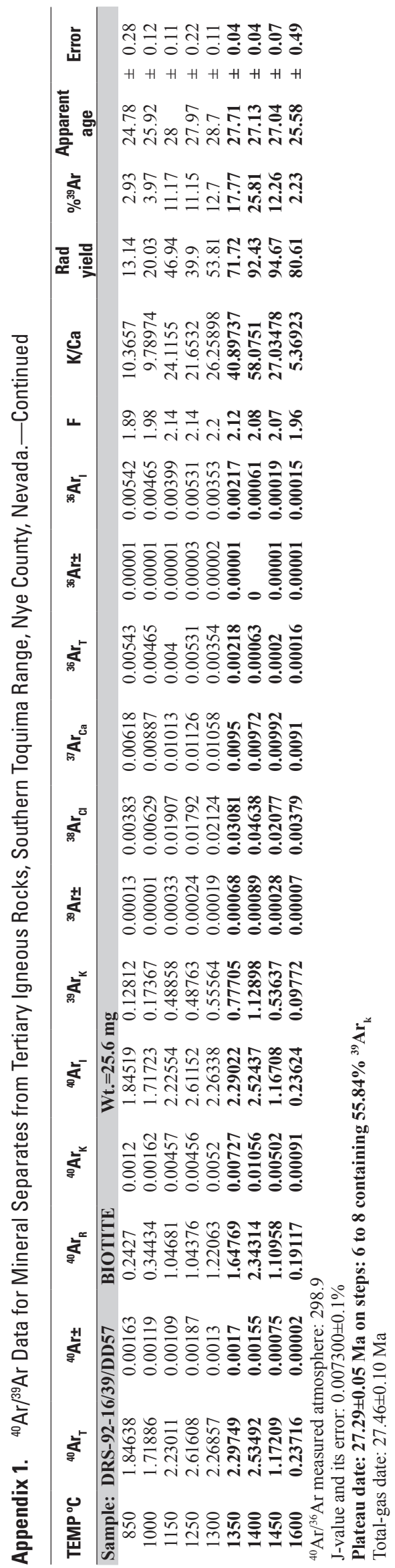

ถூำ

$\mathrm{H} H \mathrm{H} H \mathrm{H} H \mathrm{H}+\mathrm{H} H \mathrm{H}$

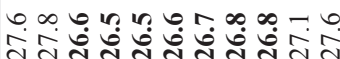

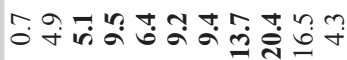

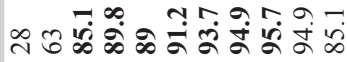

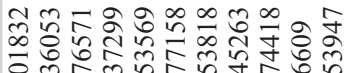

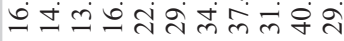

च̈

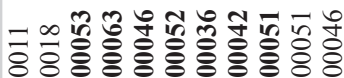

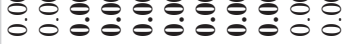

훙ㅎㅇ

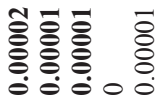

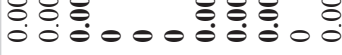

‡

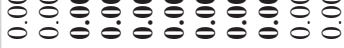

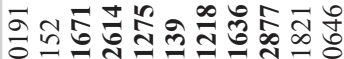

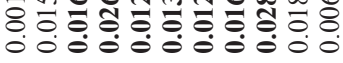

官

4

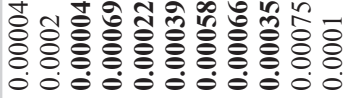

ڤ

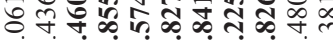

0.0

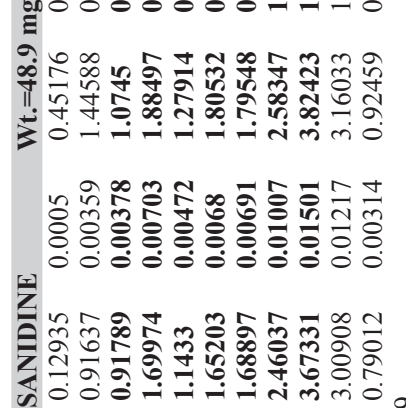

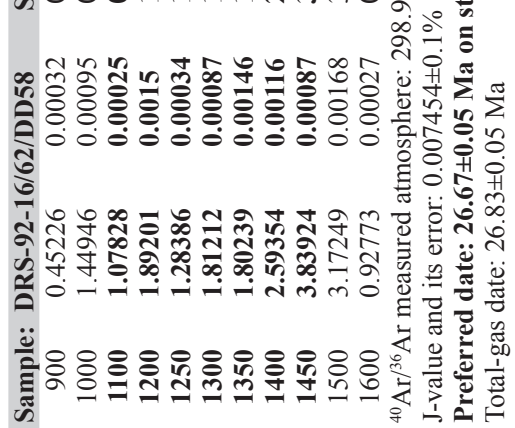

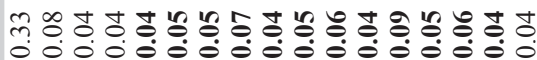

$\mathrm{H} H \mathrm{H} H \mathrm{H} H \mathrm{H} H \mathrm{H}+\mathrm{H} H \mathrm{H}+\mathrm{H} H \mathrm{H}+\mathrm{H} H \mathrm{H}$

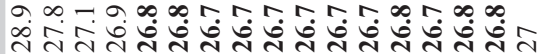

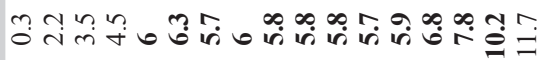

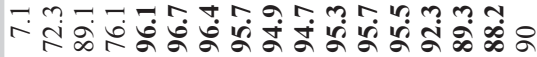

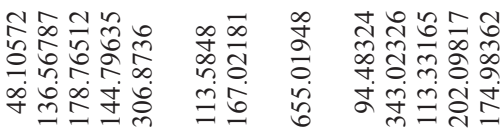

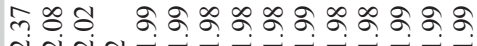

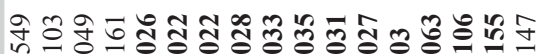

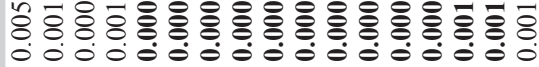

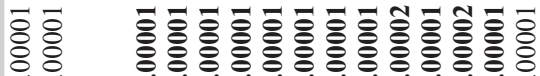

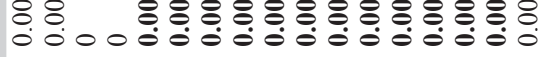
๒ ơ

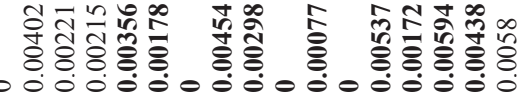
ผิ

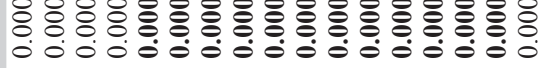

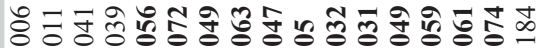
ơ

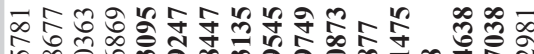
й no ฮิ่

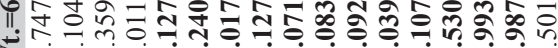

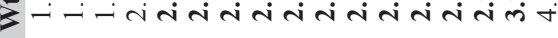

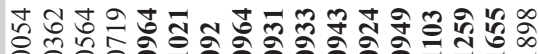

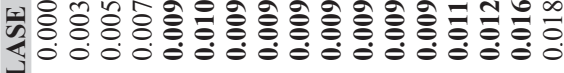
ช

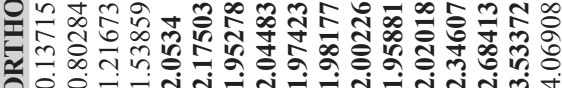

in n

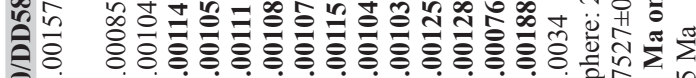

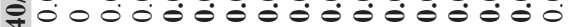
की

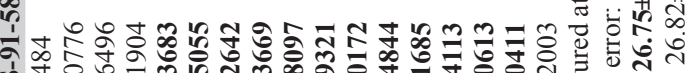

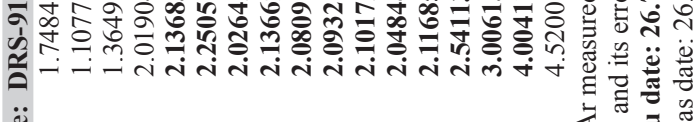

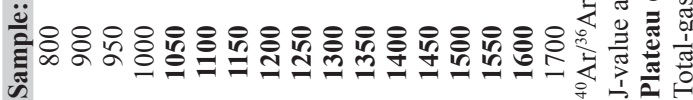




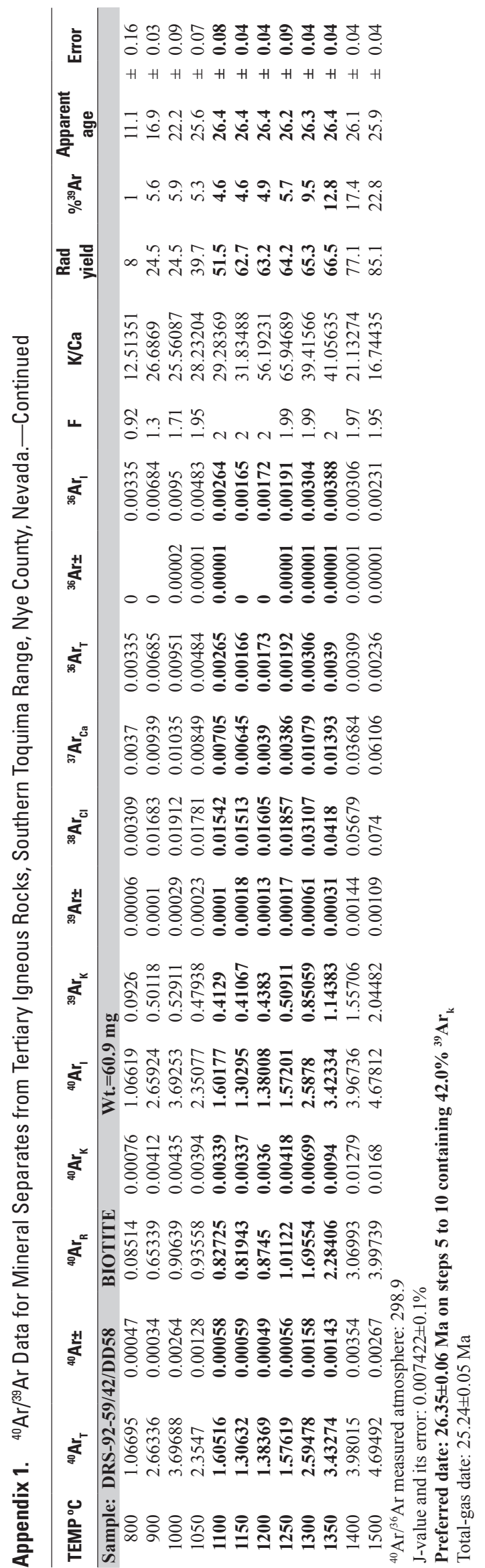

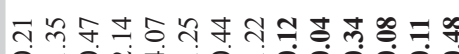

o-

H H H H H H H H H H H H H

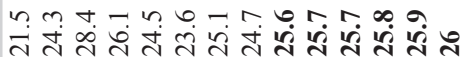

m

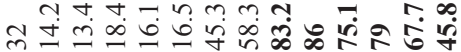

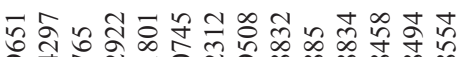

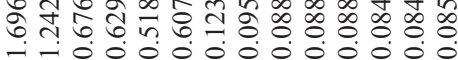

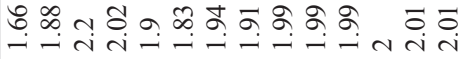

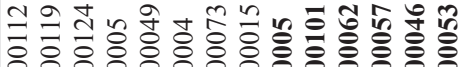
\&

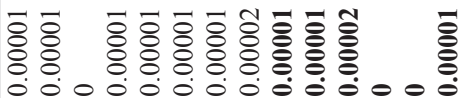

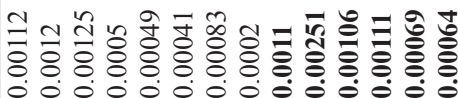

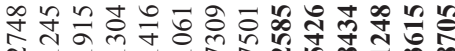
त̂̃

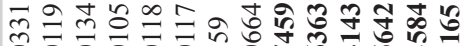

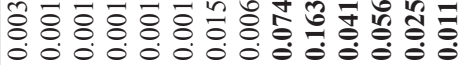

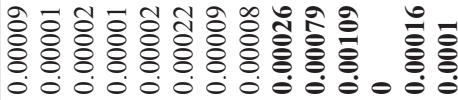

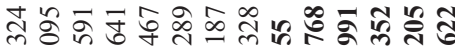

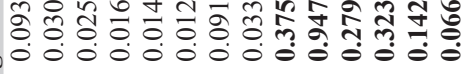

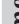

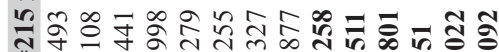

II.

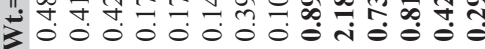

๙

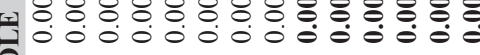

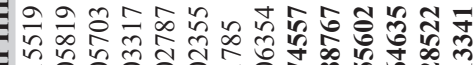
¿

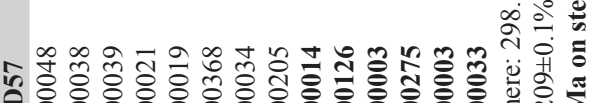

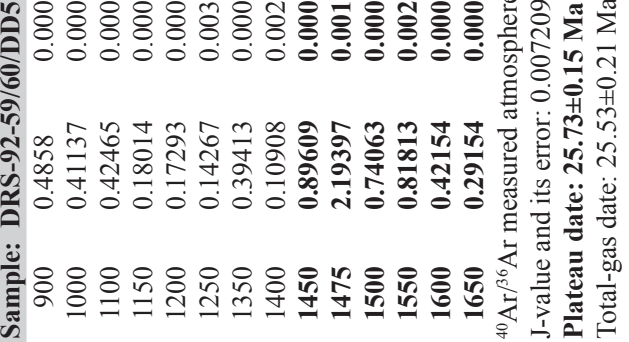




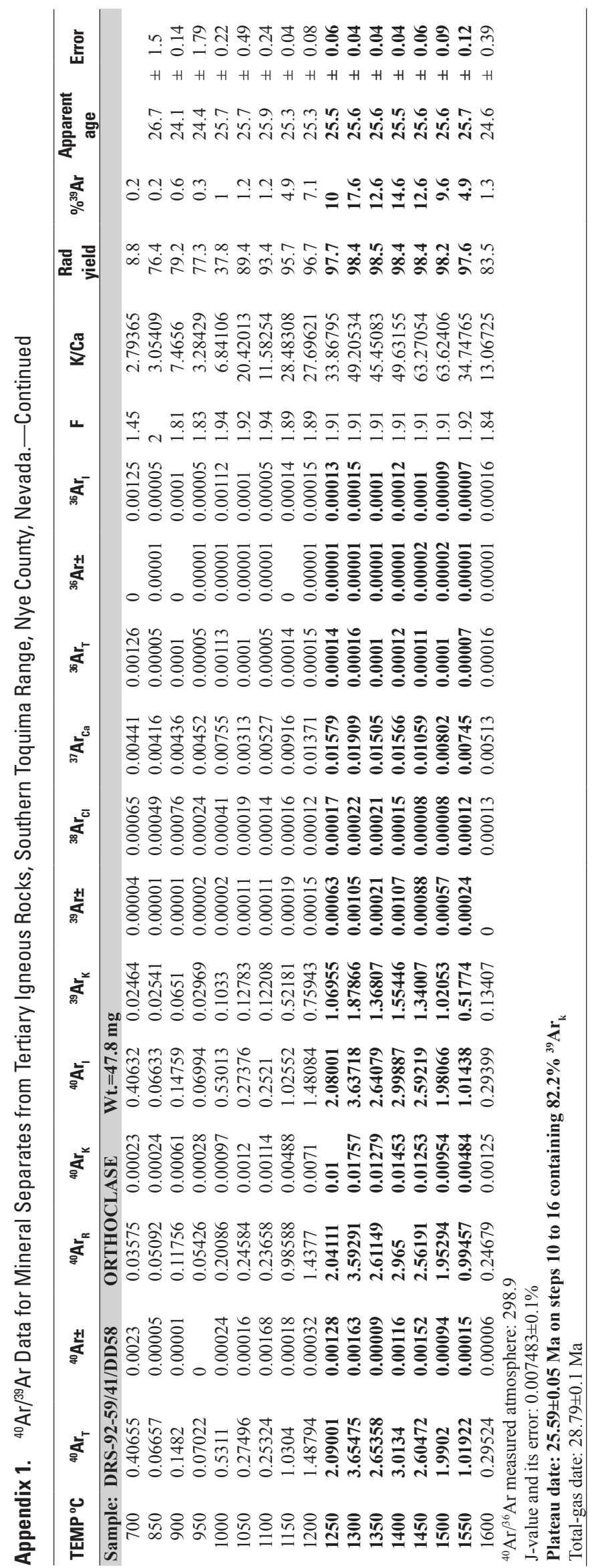





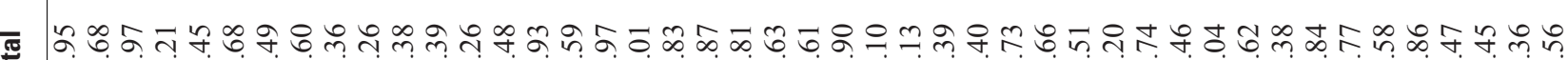

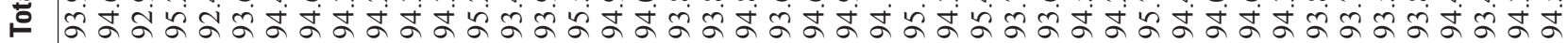

บ 000000000000000000000000000000000000000000000

ᄂ $00000000000000000000000000000000-000000000000$

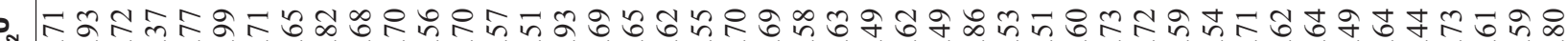

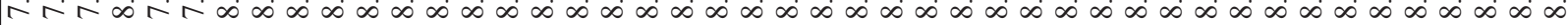

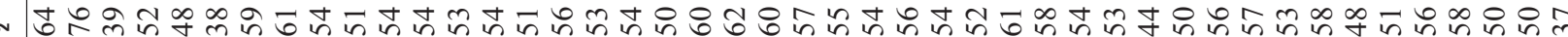
000000000000000000000000000000000000000000000

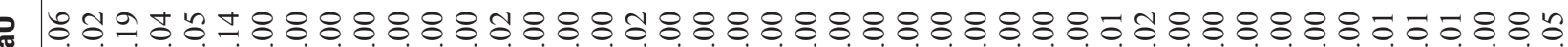
0.000000000000000000000000000000 .000000000 .000

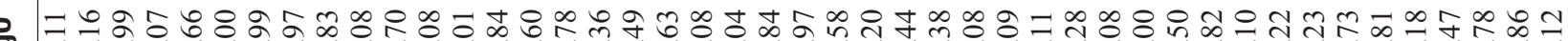

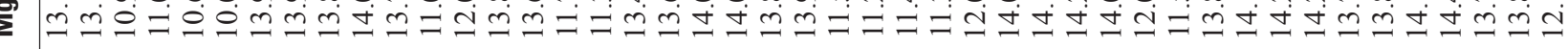

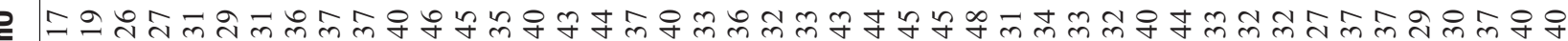
$\sum 000000000000000000000000000000000000000000000$

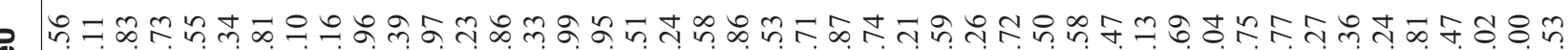

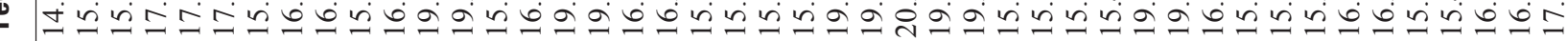

๔ லூ்

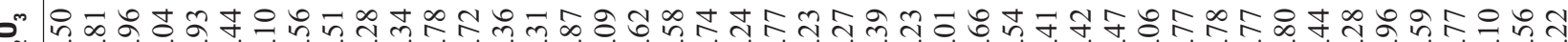

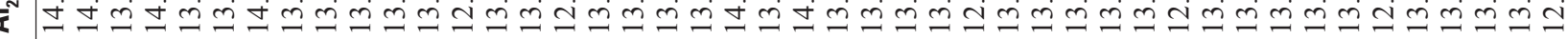

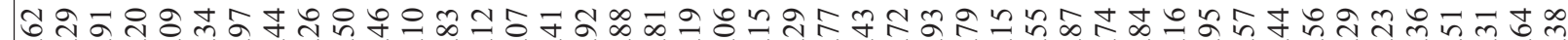

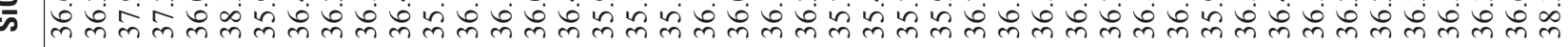
흔 mo

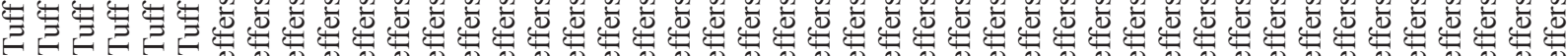

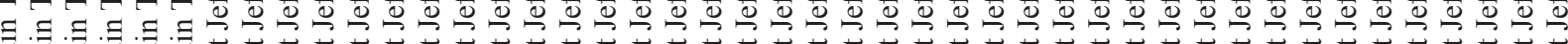

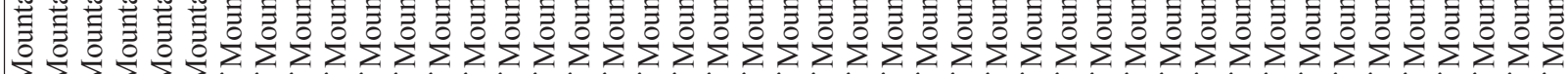

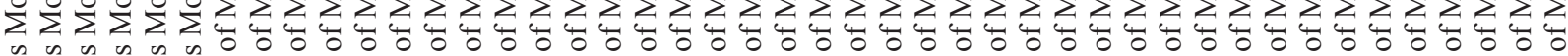

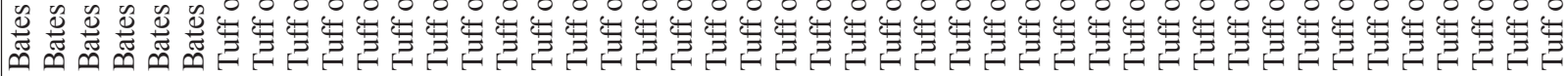


匹

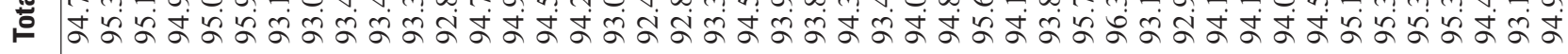

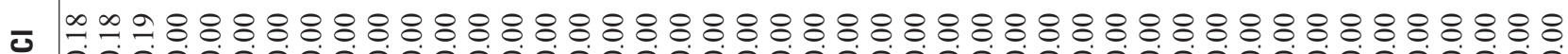

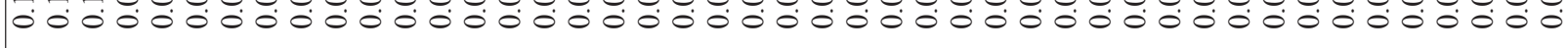

ᄂ 0000000000.00000000000000000000 .0000000000000

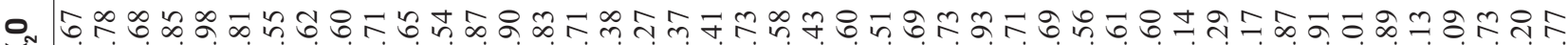

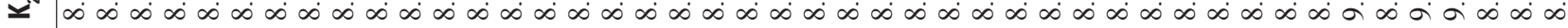

웜 $q$ q

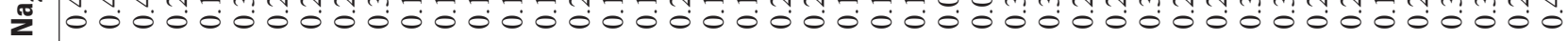

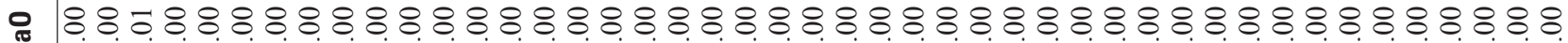

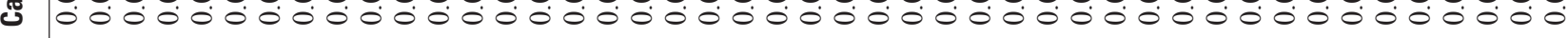

-

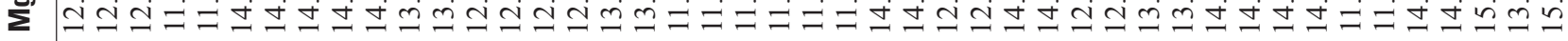

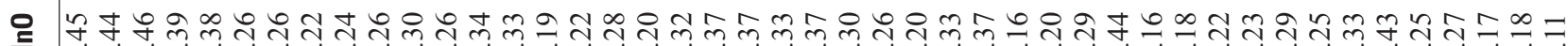

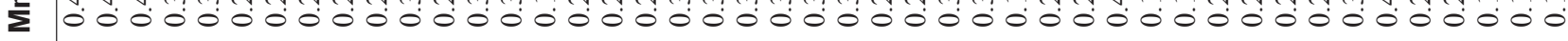

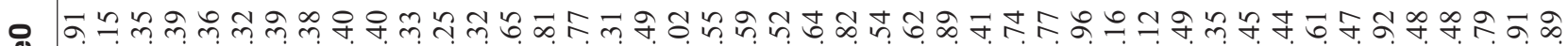

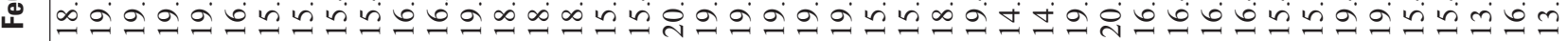

은

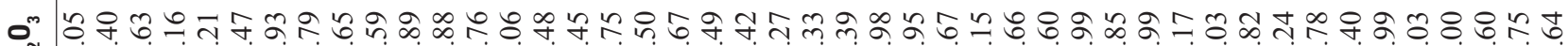

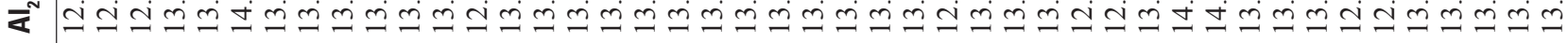

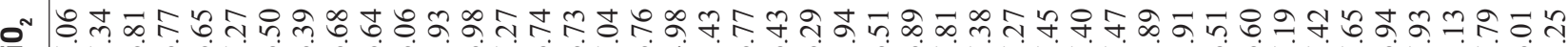

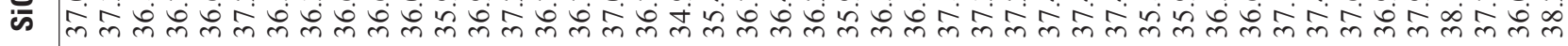

을

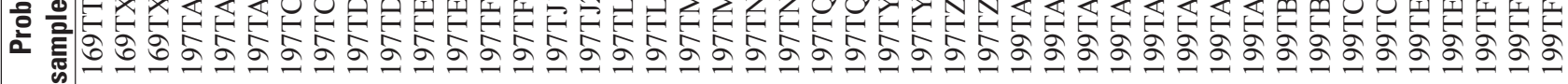

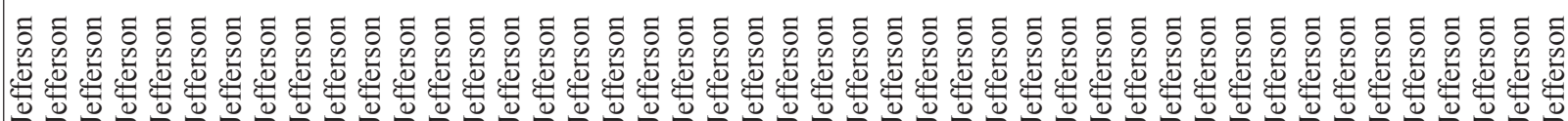

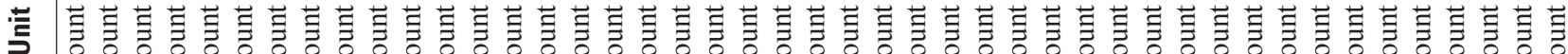

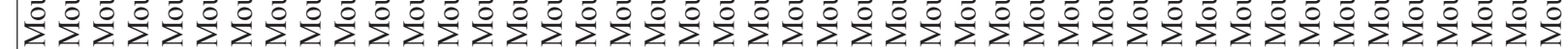

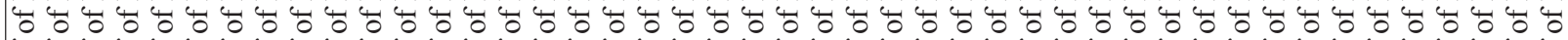

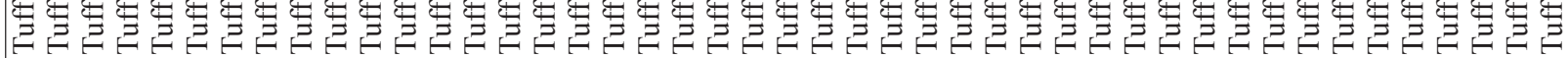

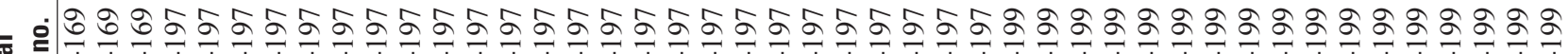

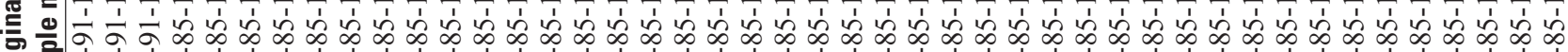

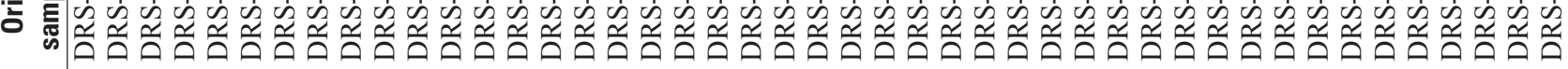


-

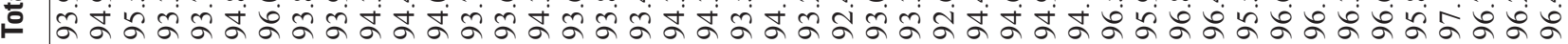

-

แ 000000000000000000000000000000000000000000000

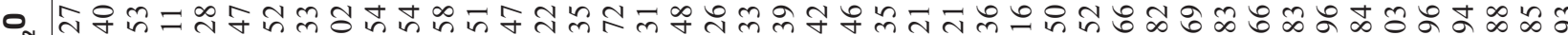

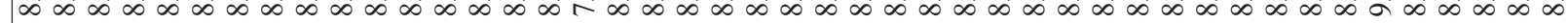

O

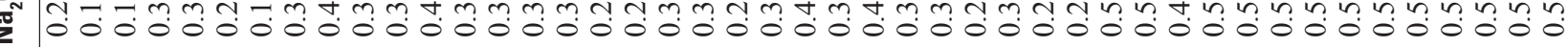

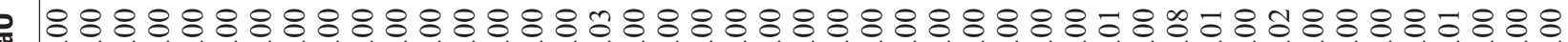

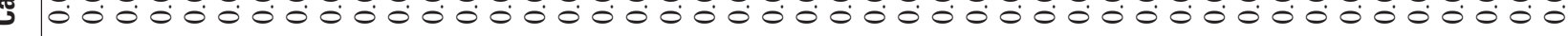

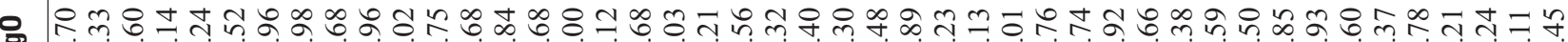

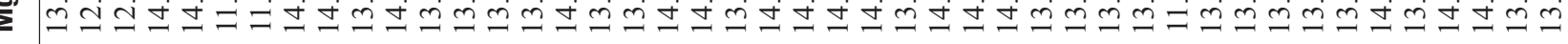

일 $\sum 000000000000000000000000000000000000000000000$

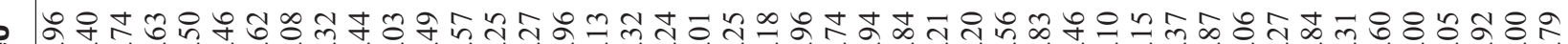
๘

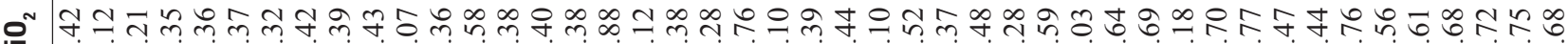

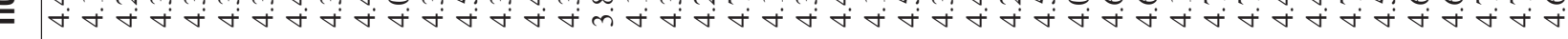

○

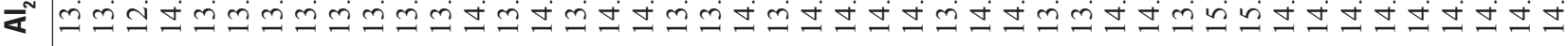

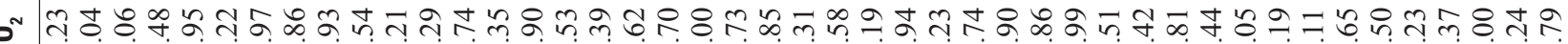

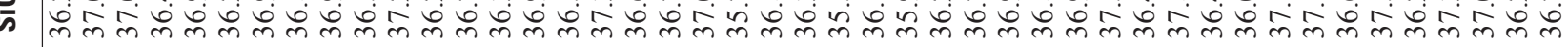

열

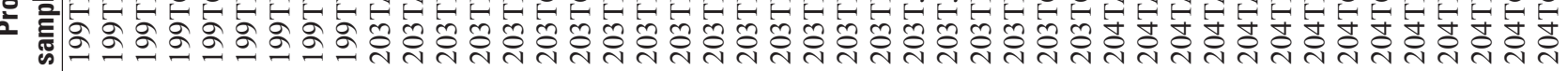

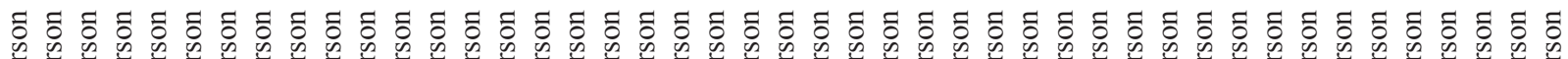

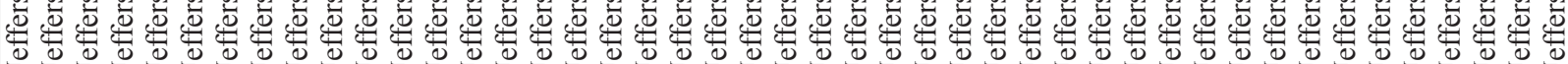

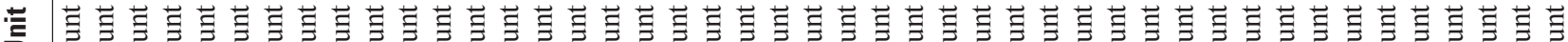

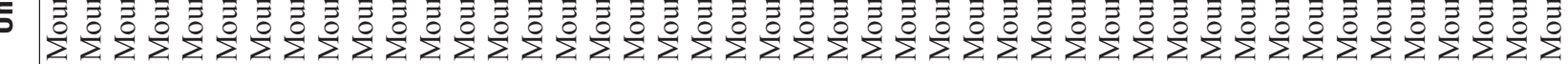

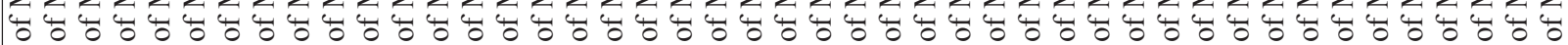

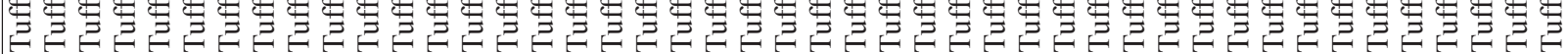

อ

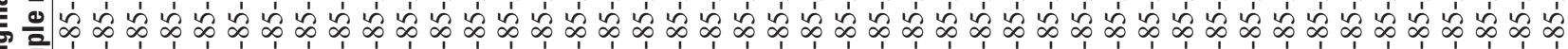




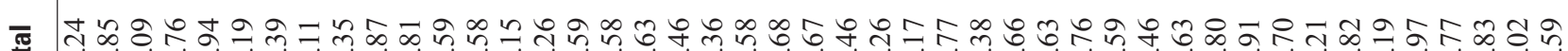

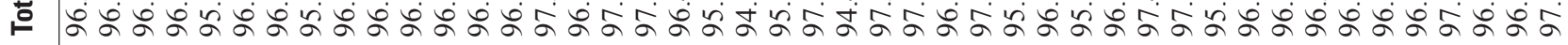

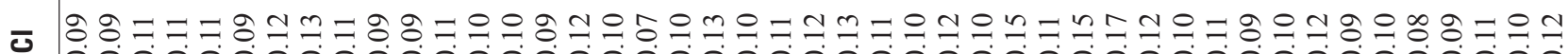
000000000000000000000000000000000000000000000

แ

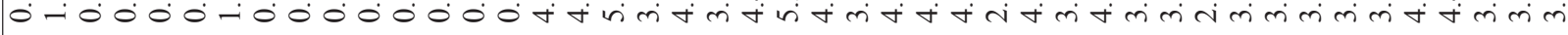

우 현

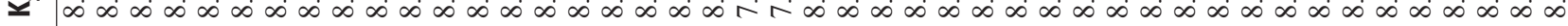

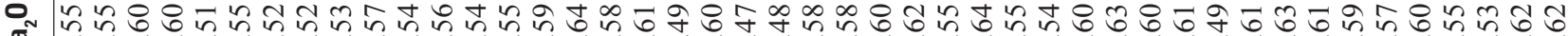

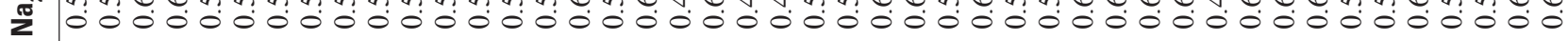

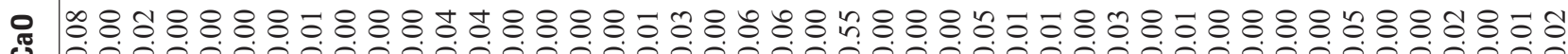

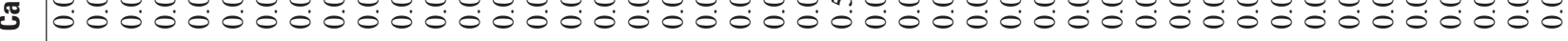

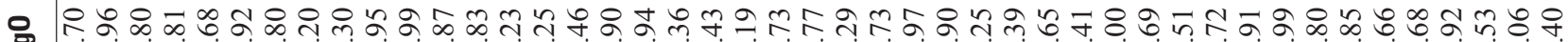

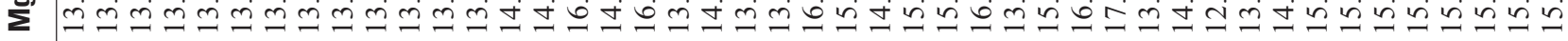

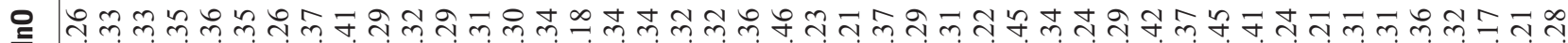
$\Sigma 000000000000000000000000000000000000000000000$

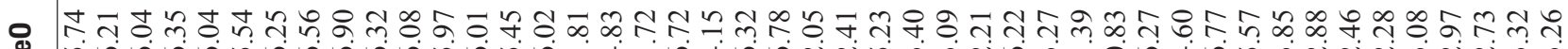

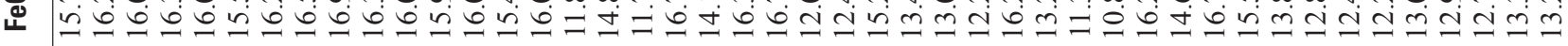

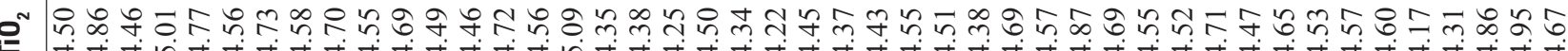

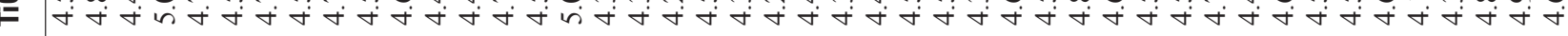

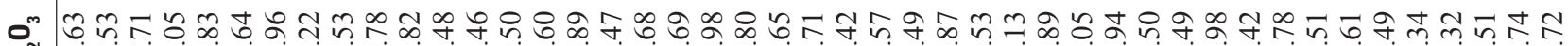

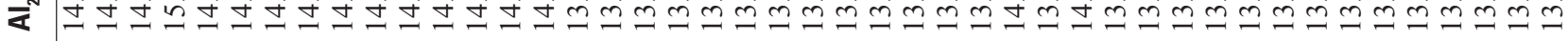

o

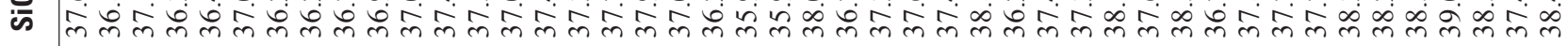

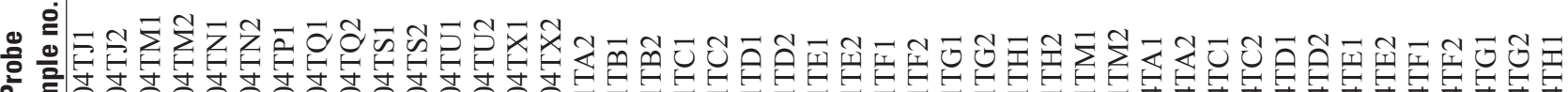

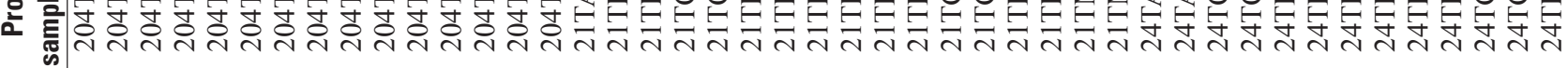

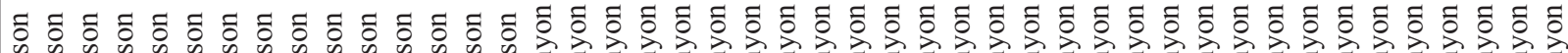

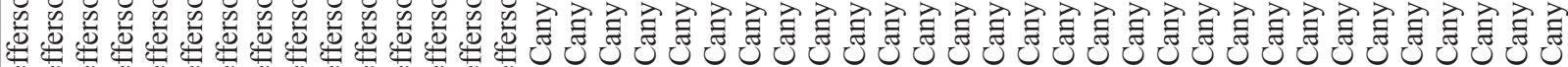

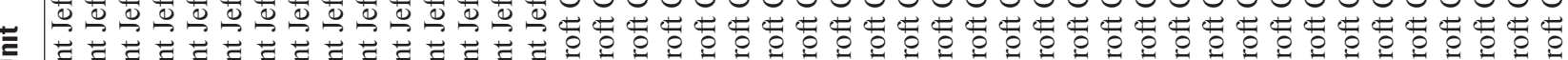

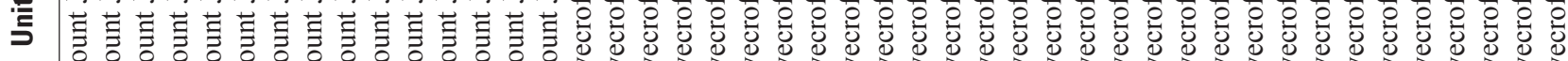

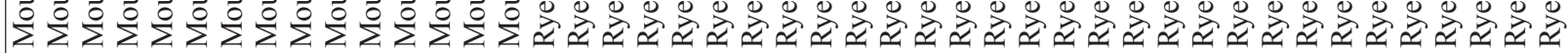

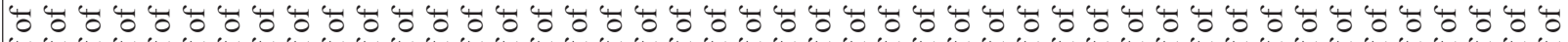

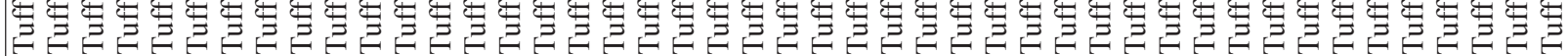

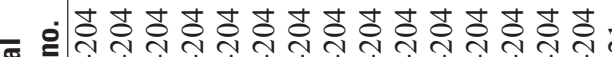

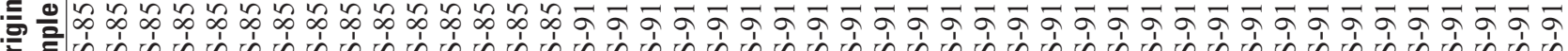

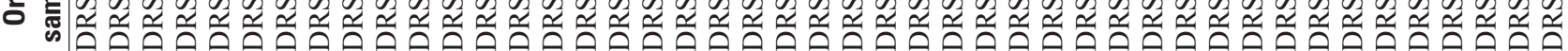




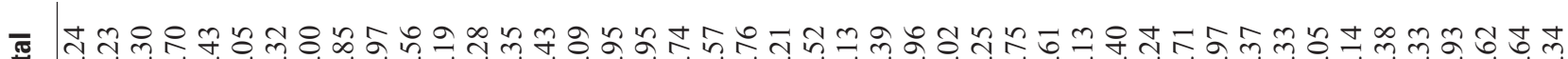

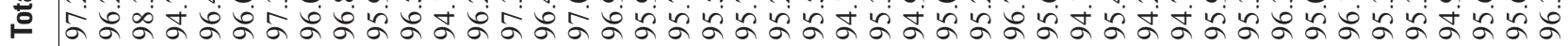

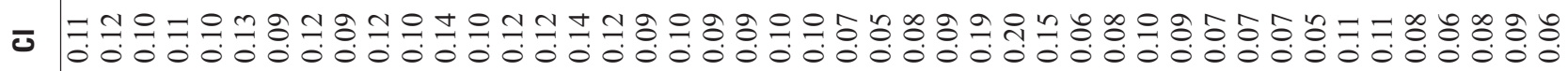

4 ঢ으ำ

-

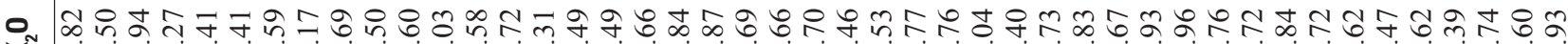

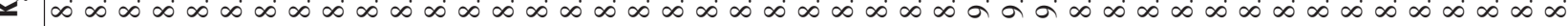

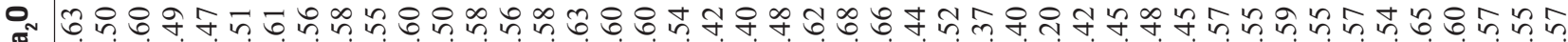

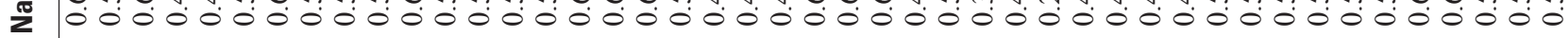

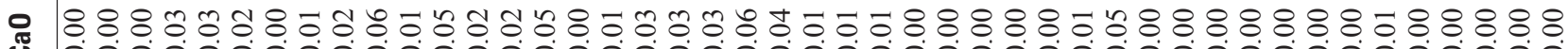

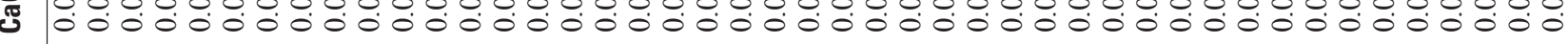

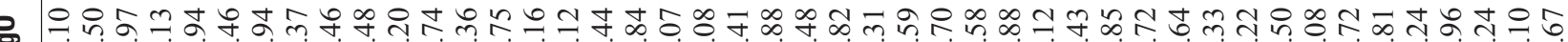

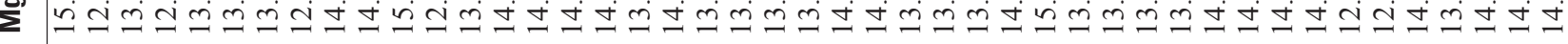

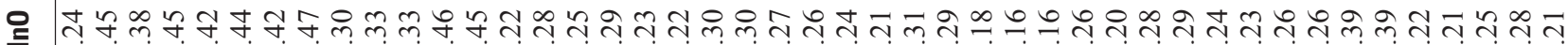
$\sum 000000000000000000000000000000000000000000000$

- చํำ

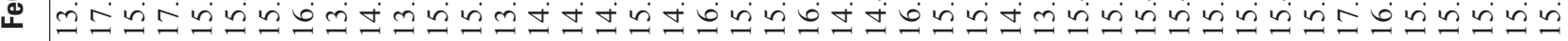

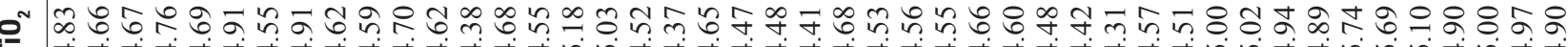

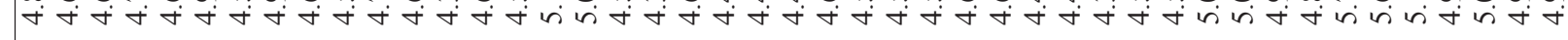

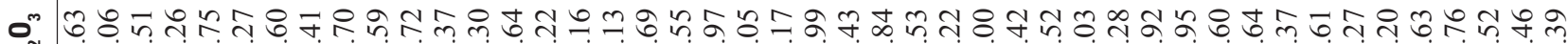

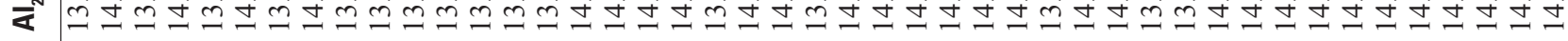

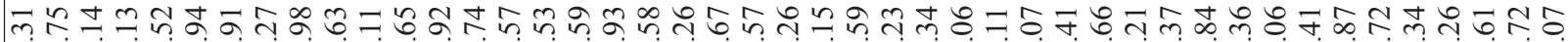

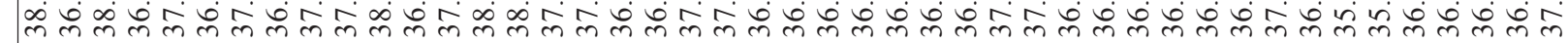

은

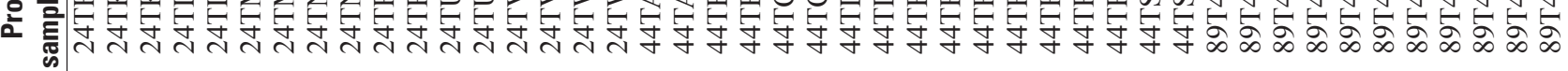

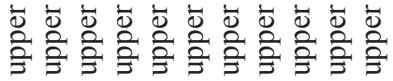

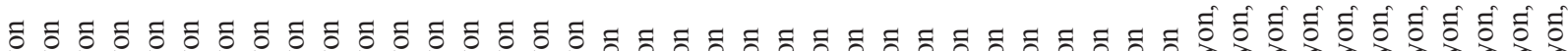

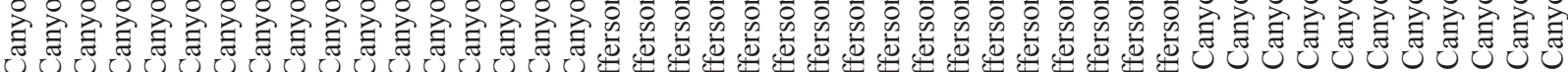
氚

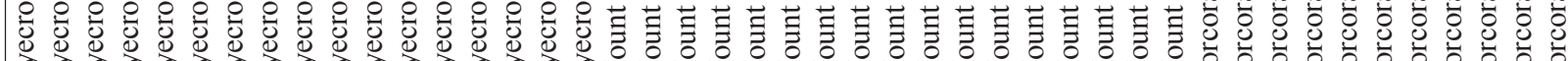

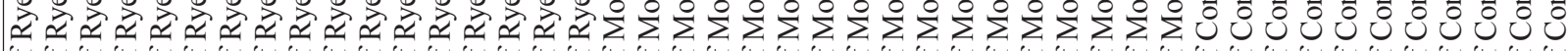

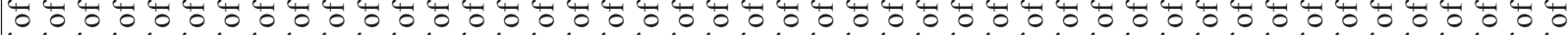

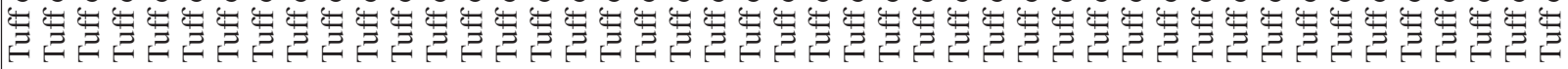

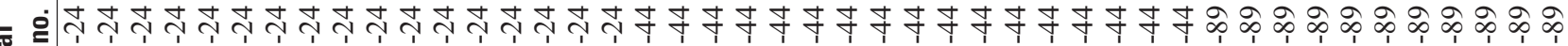

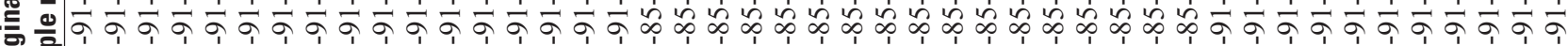

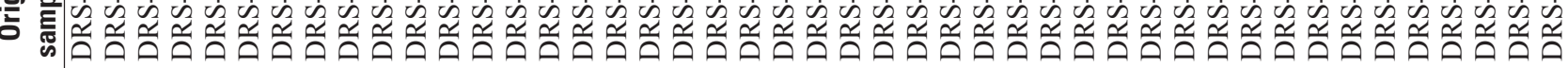




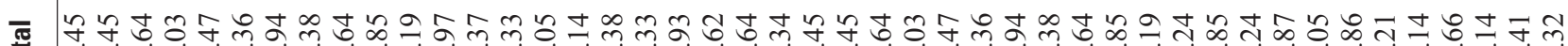

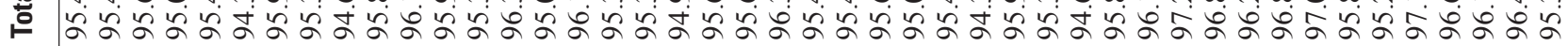

ত

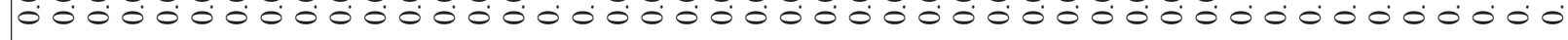

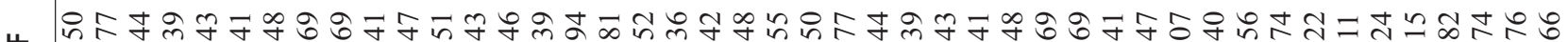
$000000000000000000000000000000000-1000-1-10000$

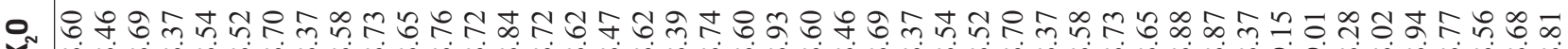

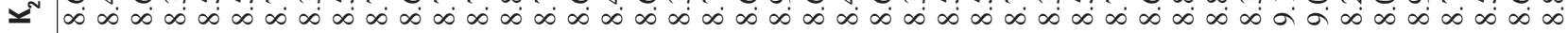

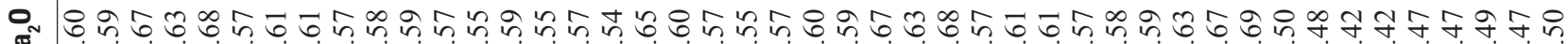

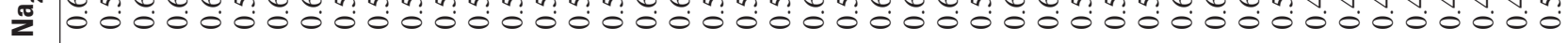

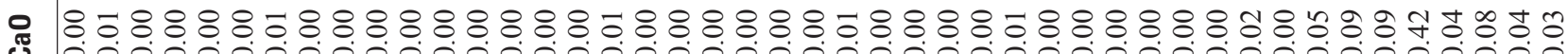

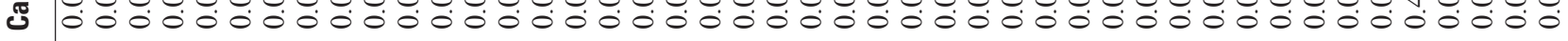

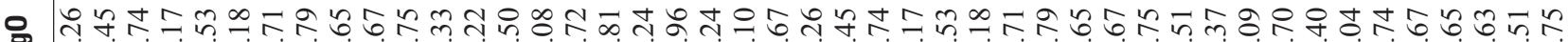

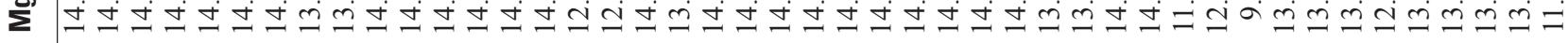

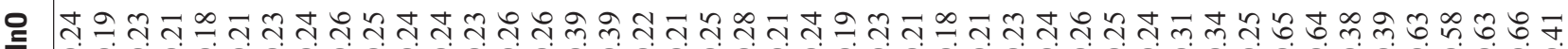

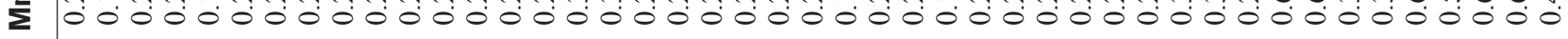

o ㅇํ

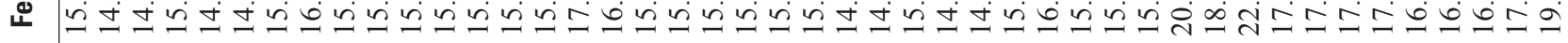

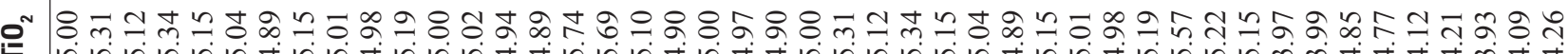

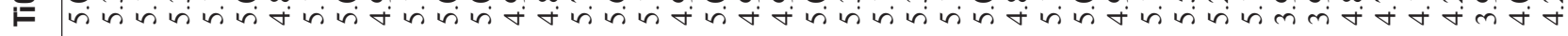

○

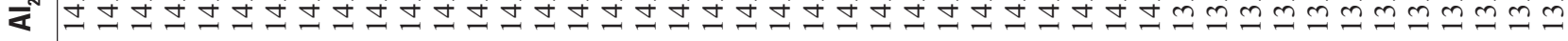

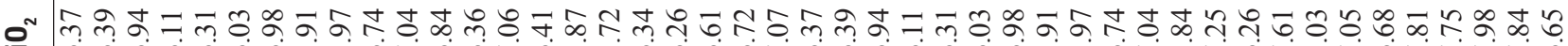

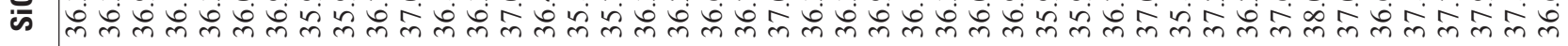

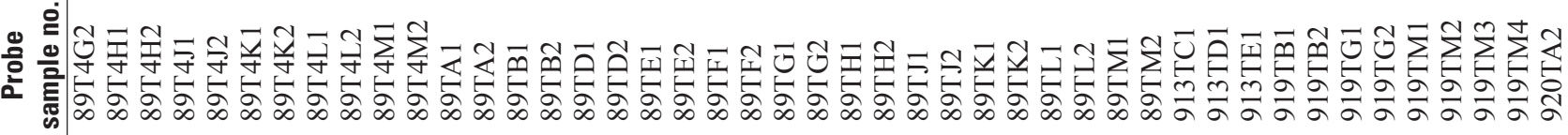

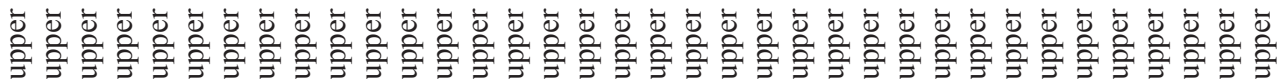

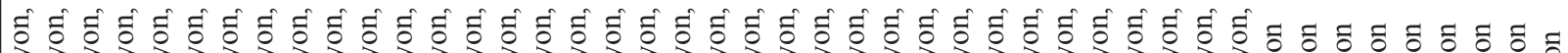

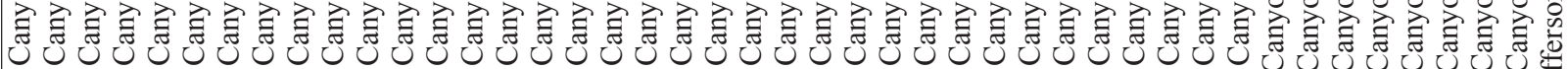

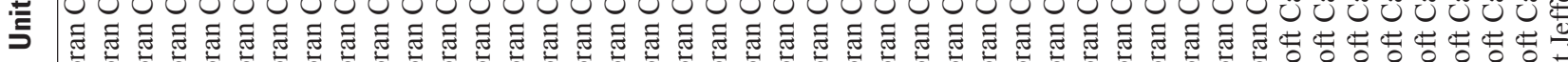

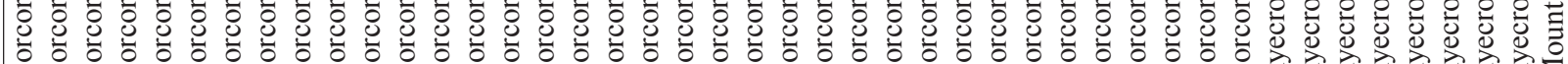

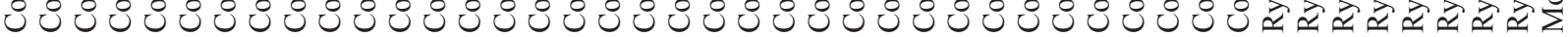

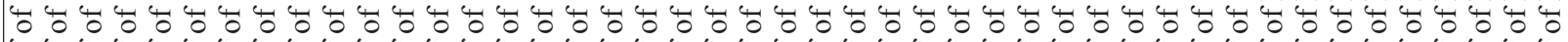

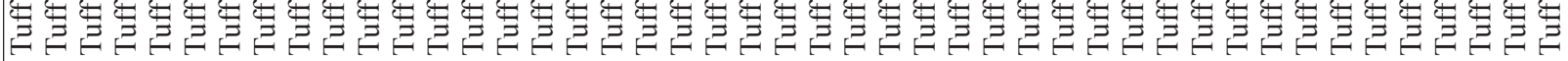




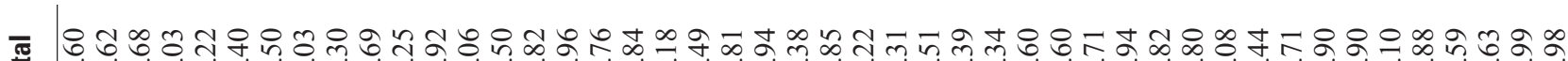

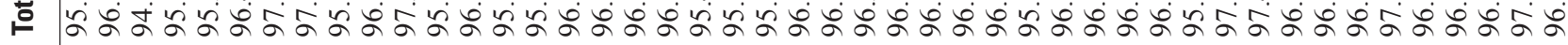

অ $000000000000000000000000000000000000000000000^{\circ}$

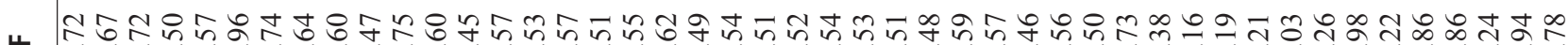
- 000000000000000000000000000000ntimmtrintitmm

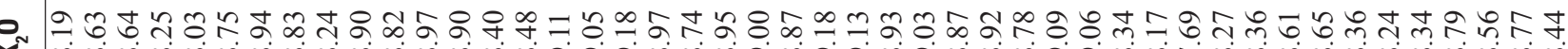

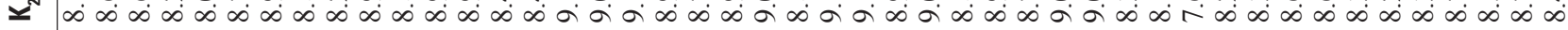

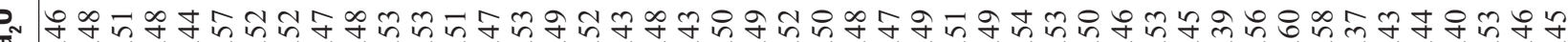

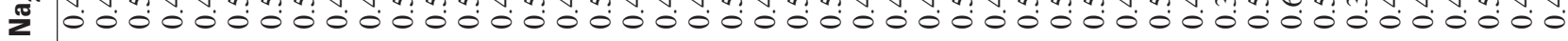

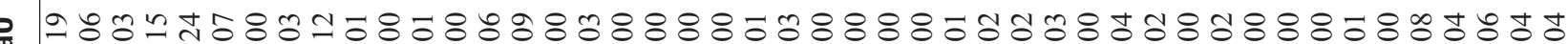
I 0000000000000000000000000000000000000000000000

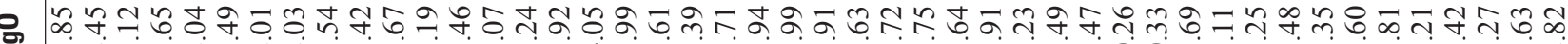

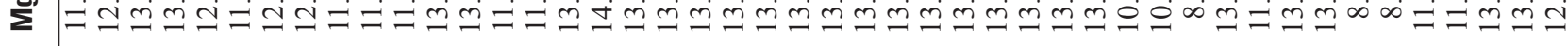

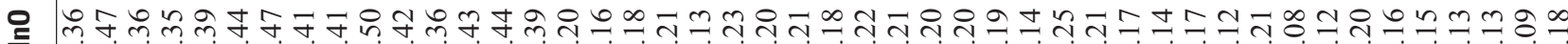
$\Sigma 0000000000000000000000000000000000000000000000$

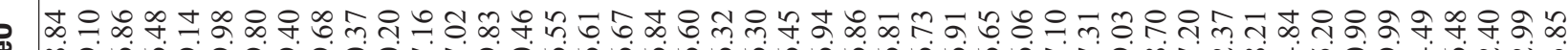

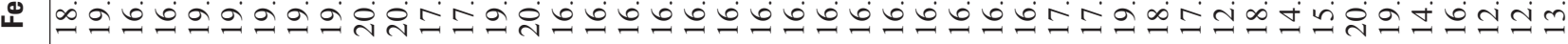

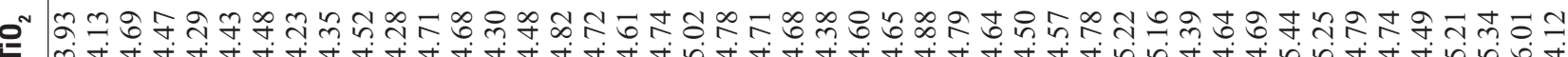

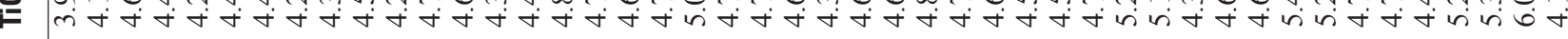

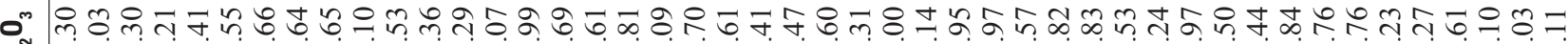

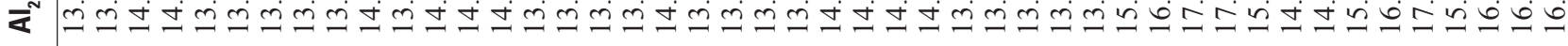

0

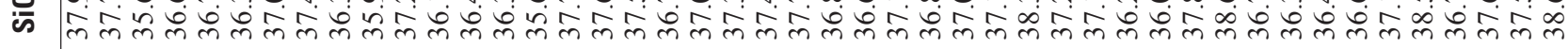

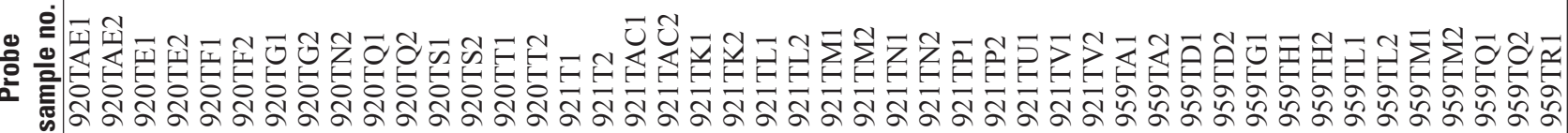

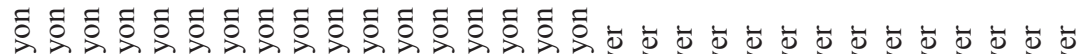

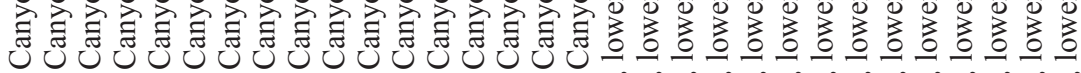
=

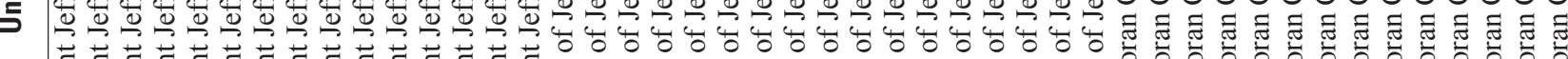

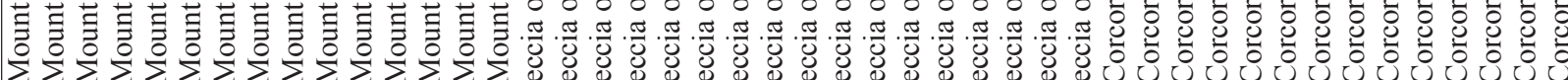

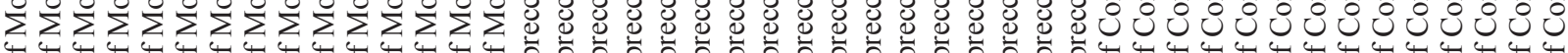

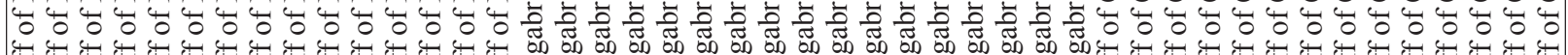

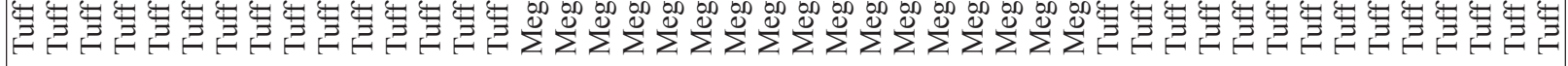

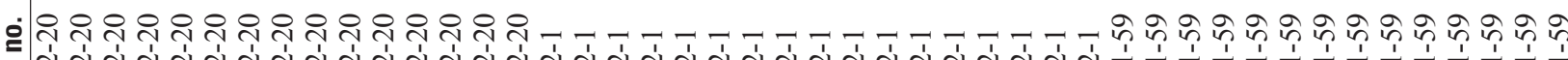

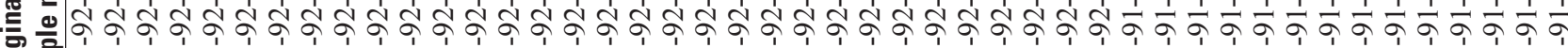

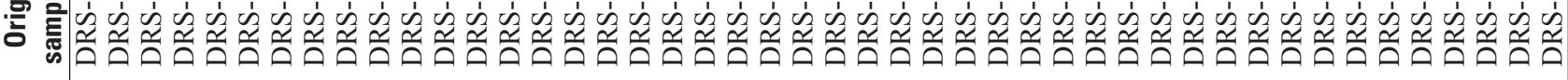





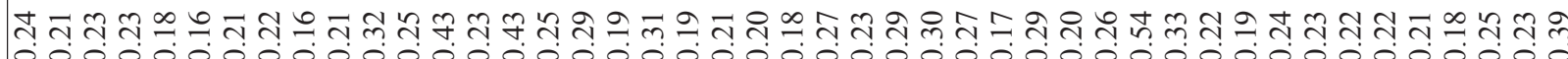

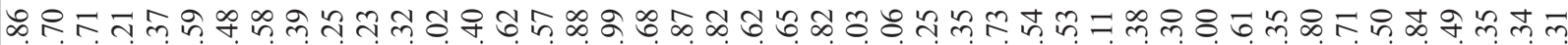

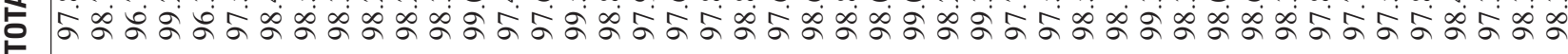

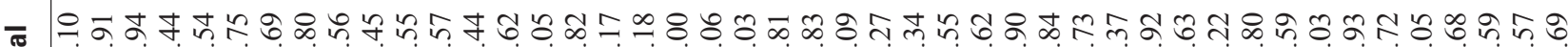

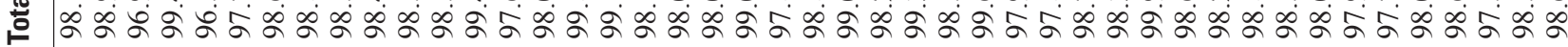

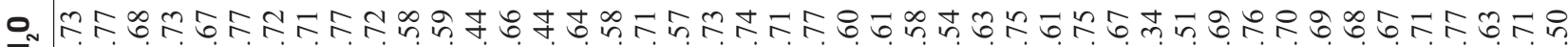

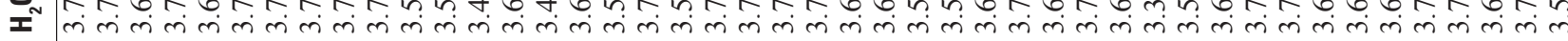

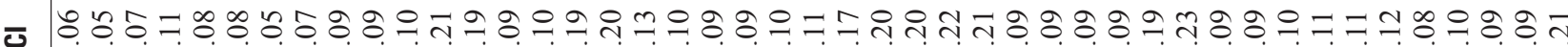
0.000000000000000000000000000000000000000000

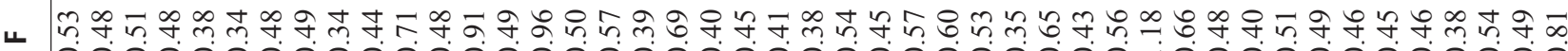
00000000000000000000000000000000.000000000000

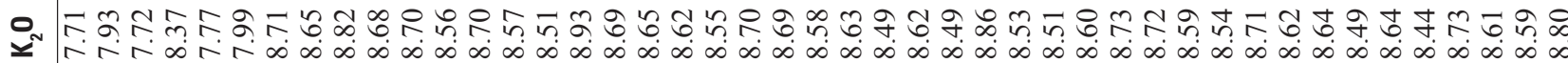

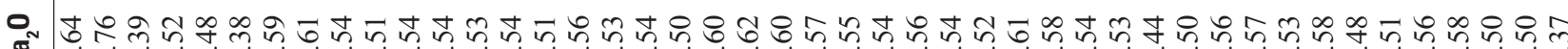

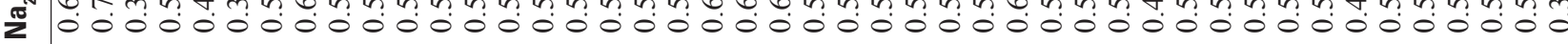

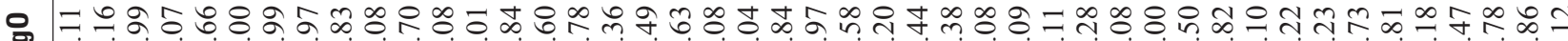

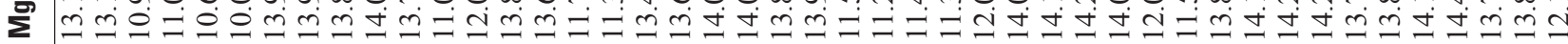

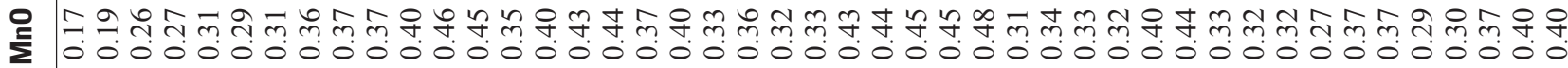

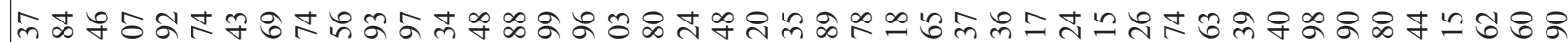

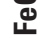

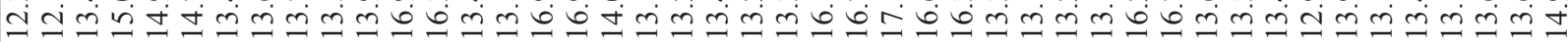

০ ๆ

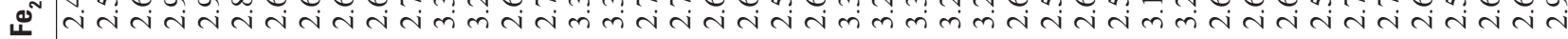

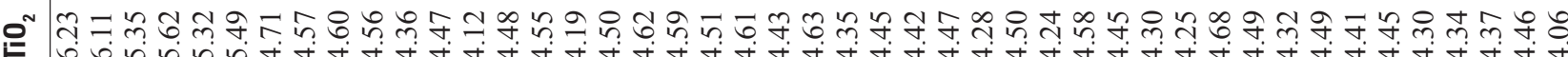
ல்

○

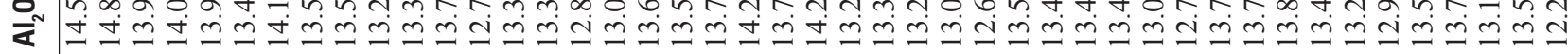

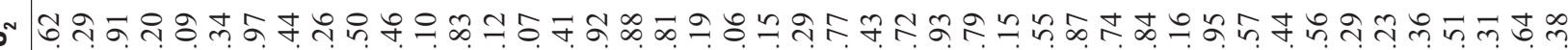

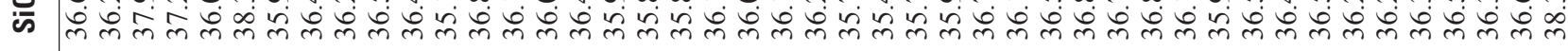

希

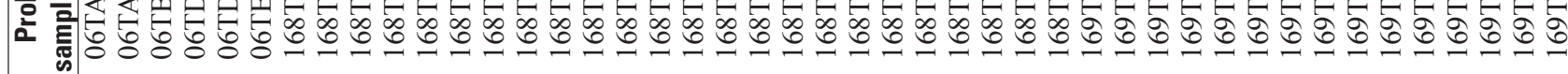




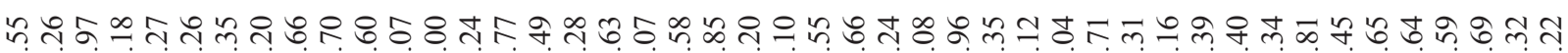

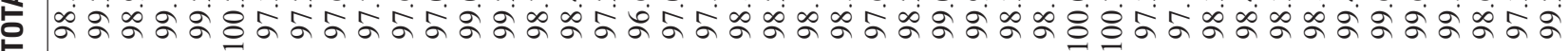
ग्र

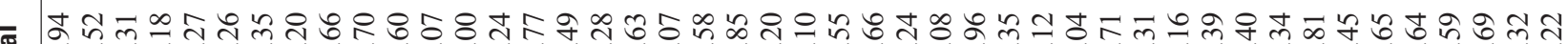
ڤ̆

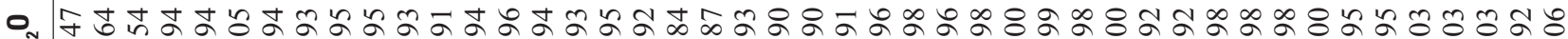
I

ज 000000000000000000000000000000000000000000000

ᄂ

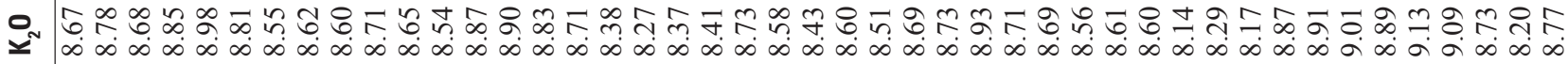

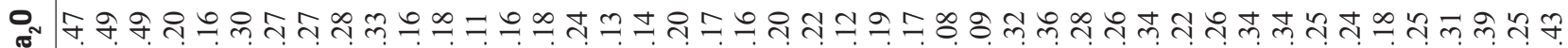

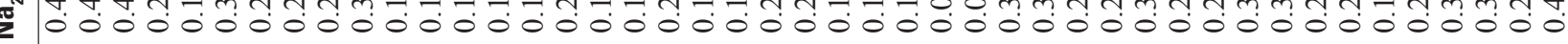

음 후

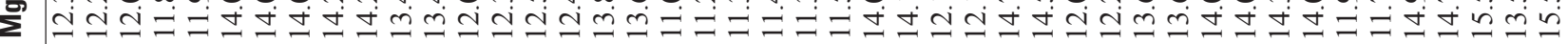

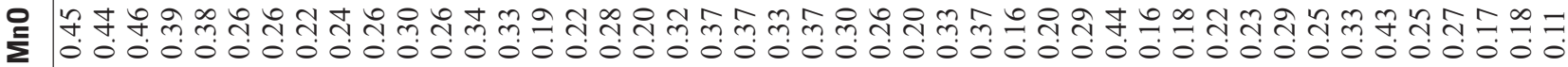

윽ำ 山்

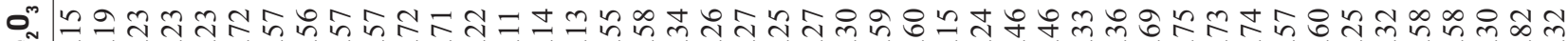

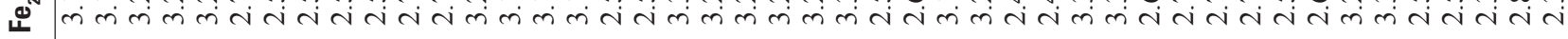

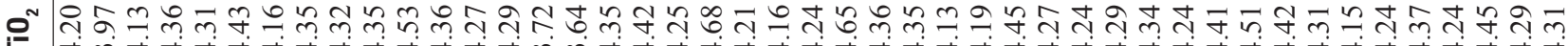

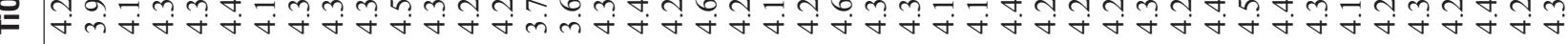

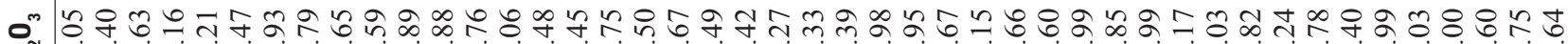
स゙

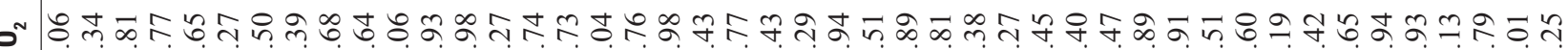

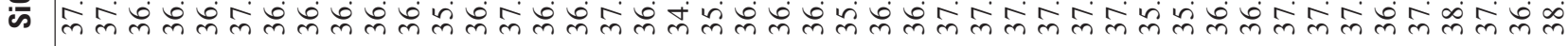

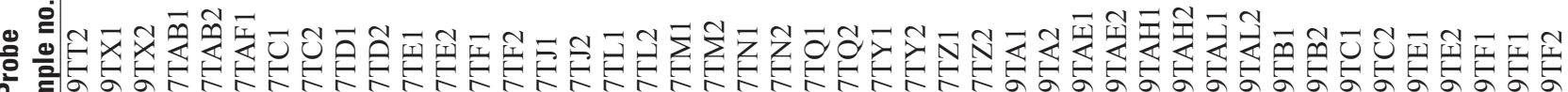

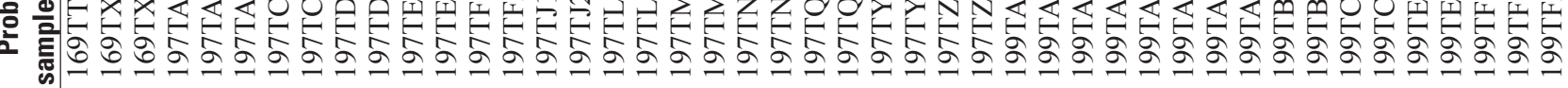




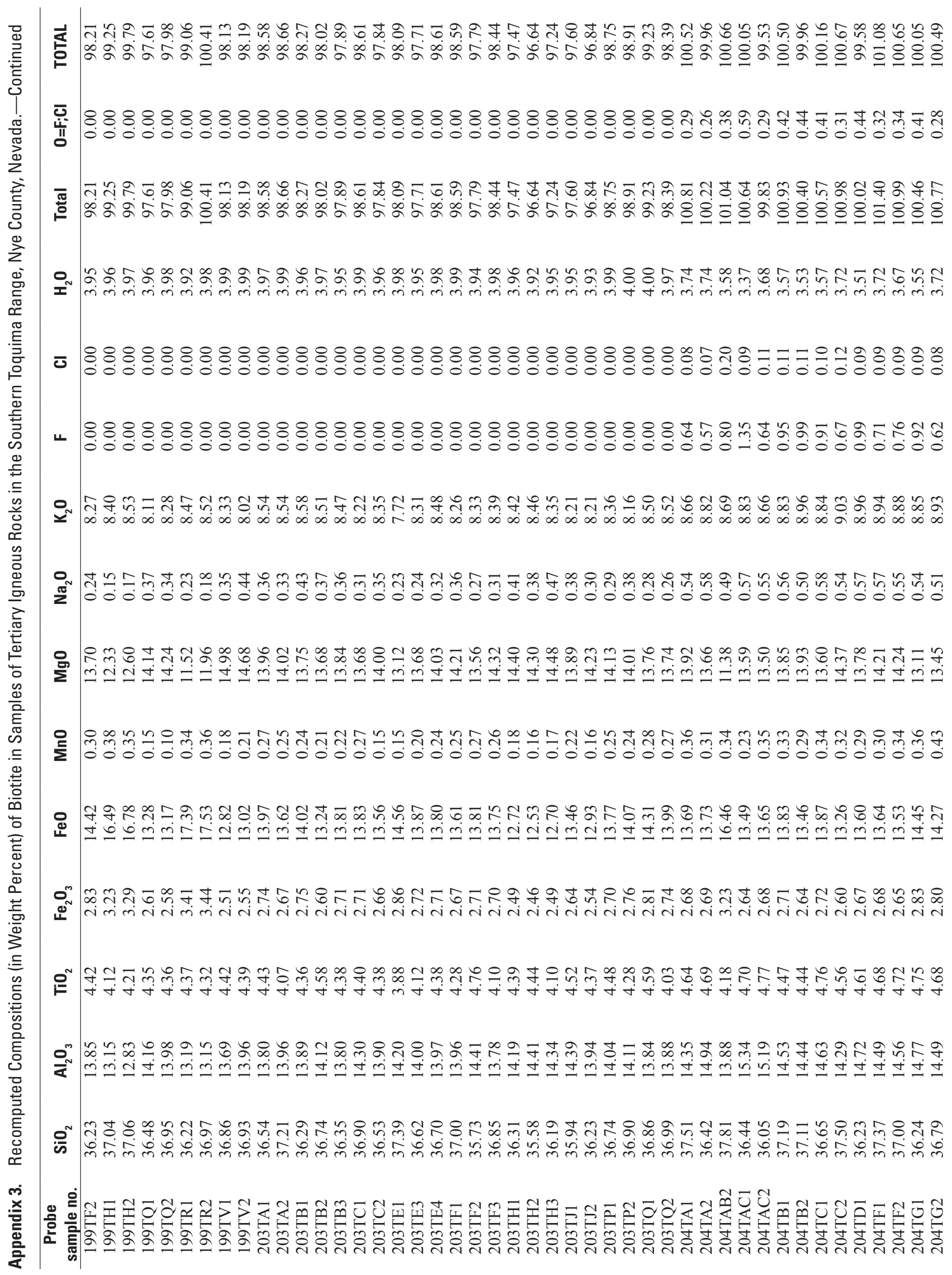




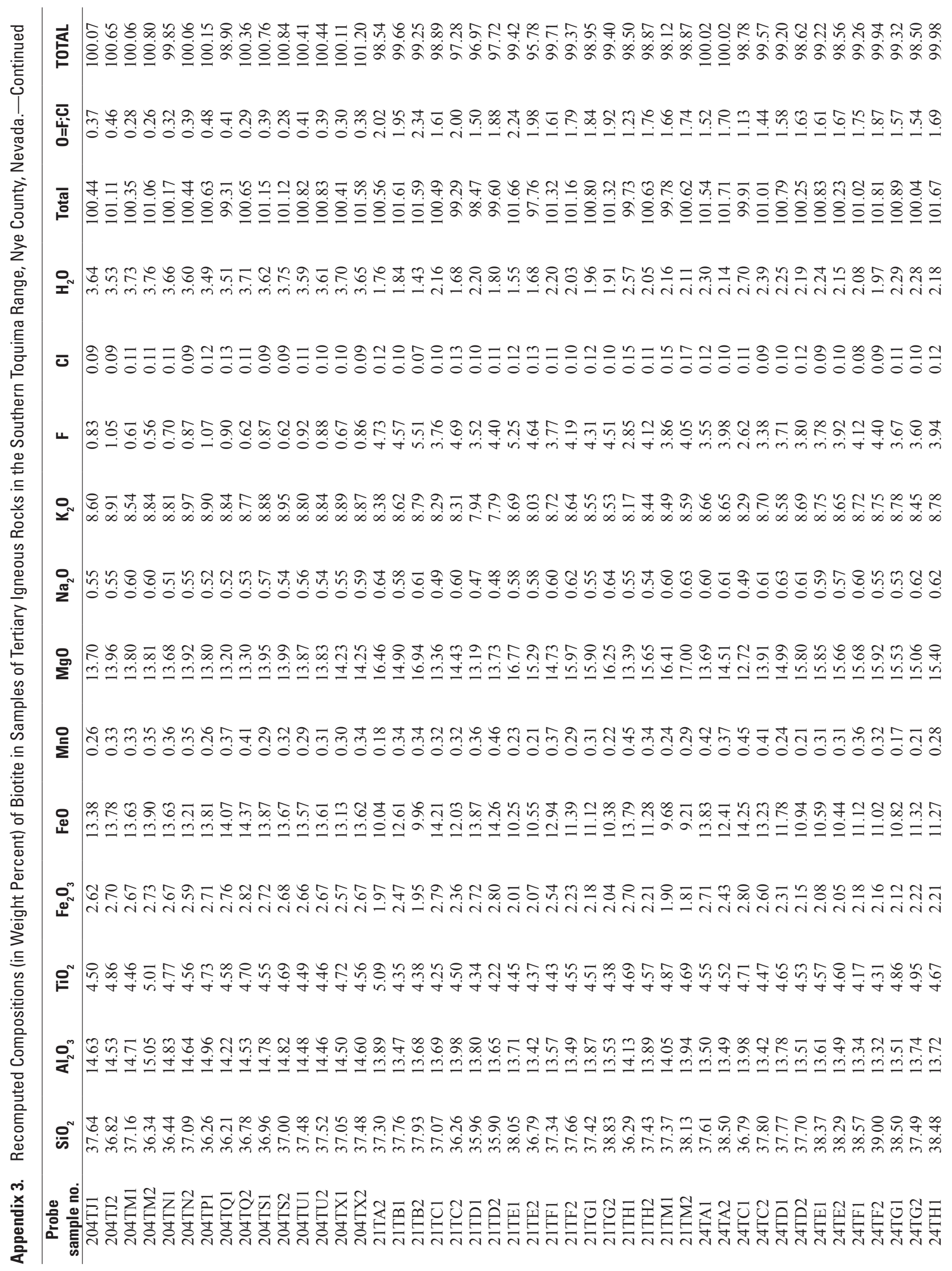




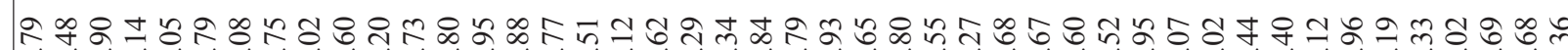
进

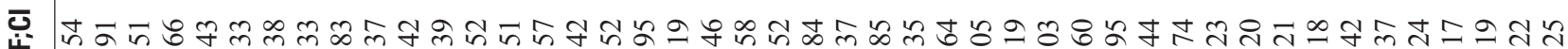

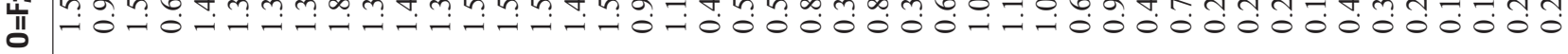

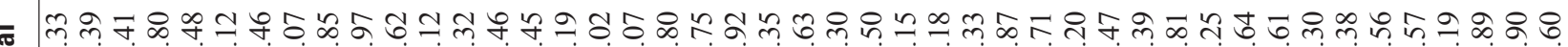

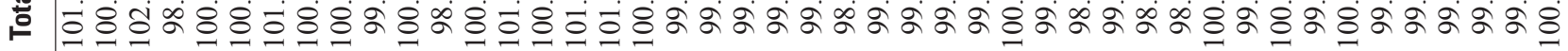

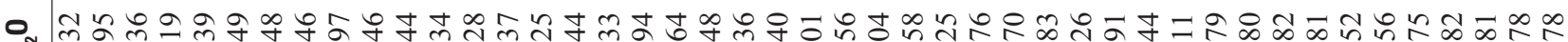
I $\mathrm{N}$ त

크늑의

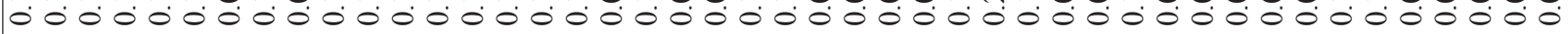

- ঢ으ำต

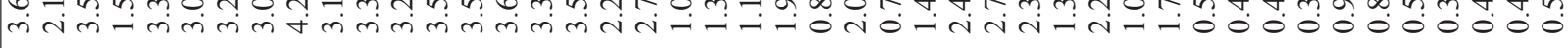

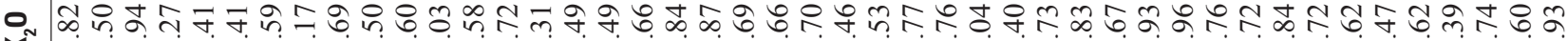

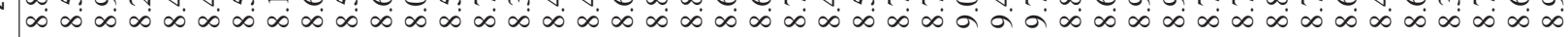

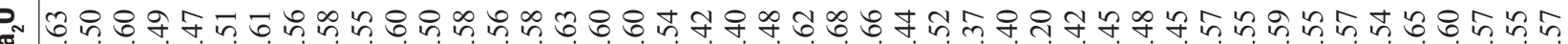
贸

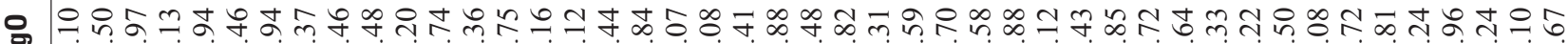

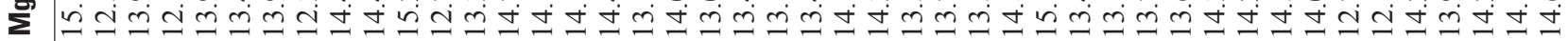

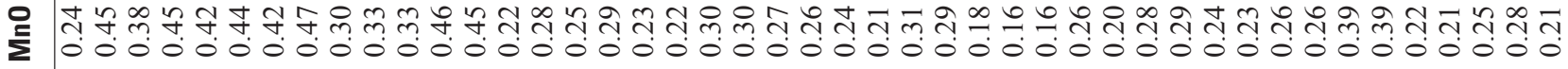

舟少

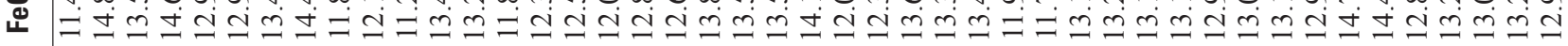

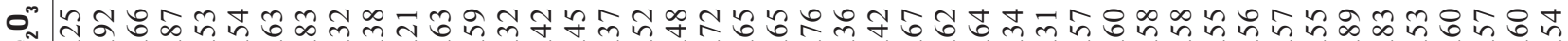
एँ

은

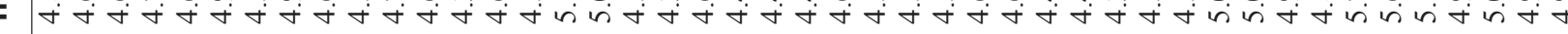

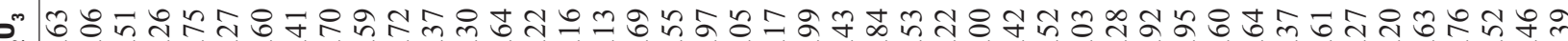

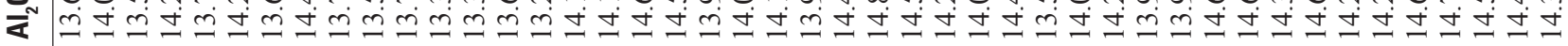

๙

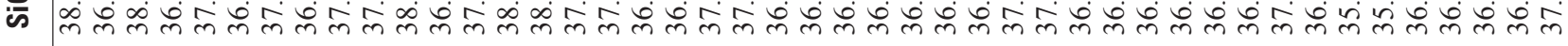

。

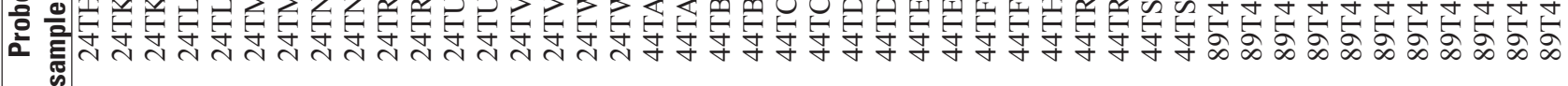


स

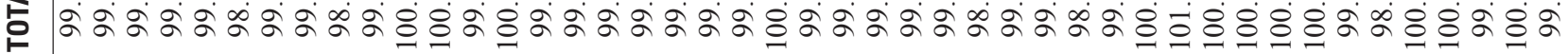

푼

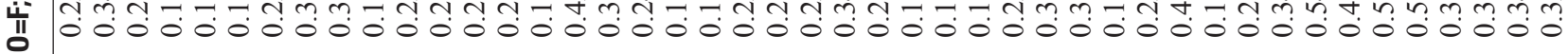

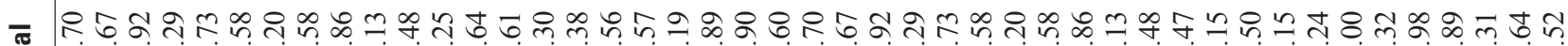

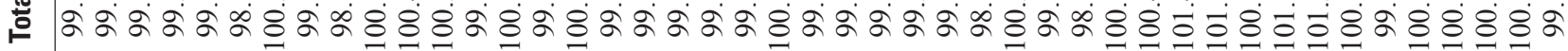

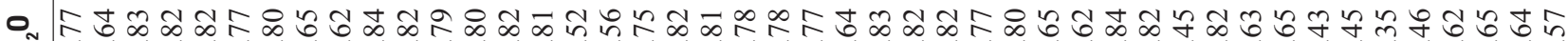

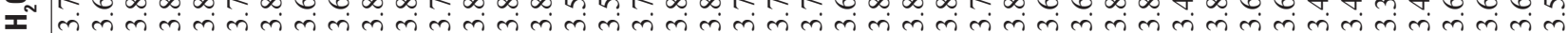

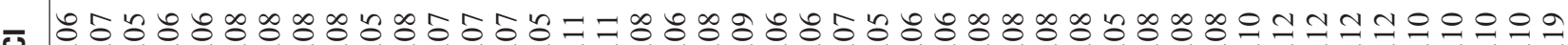
000000000000000000000000000000000000000000000

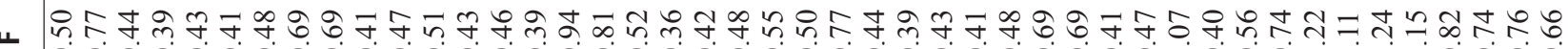
$000000000000000000000000000000000-0001-1.0000$

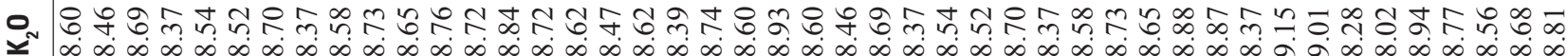

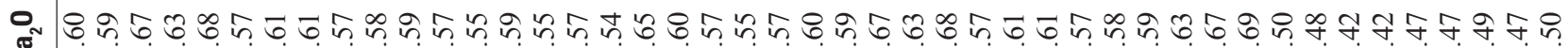

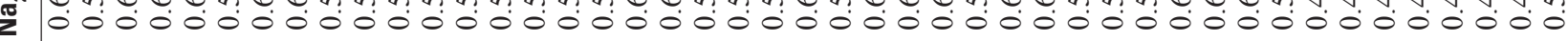

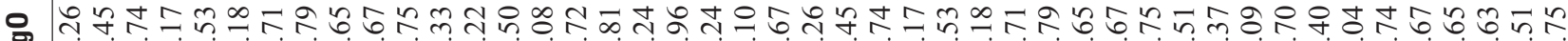

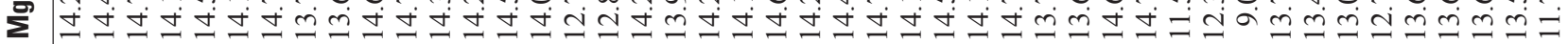

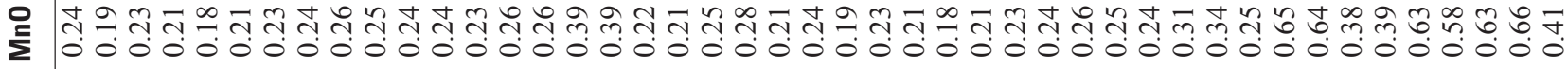

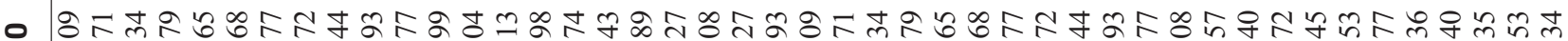
๖

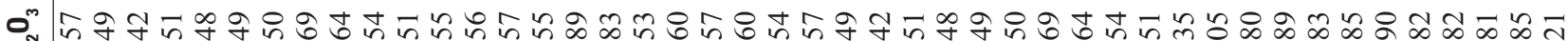

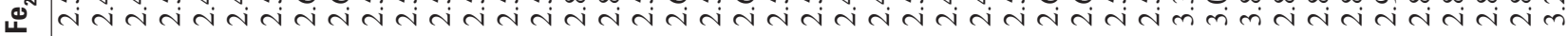

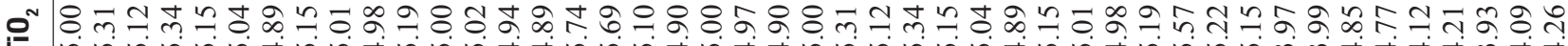
它

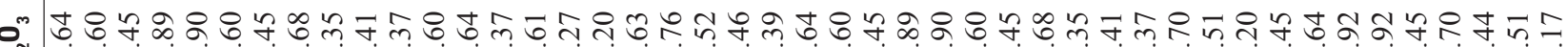

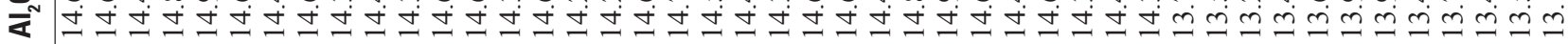

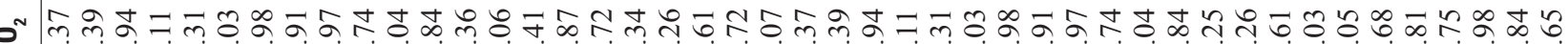

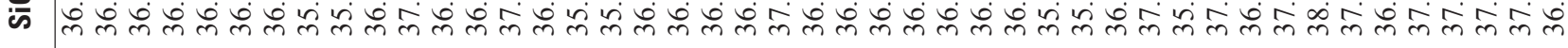

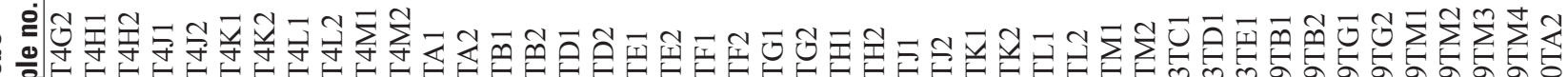

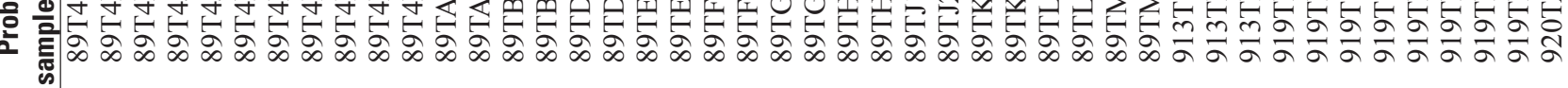




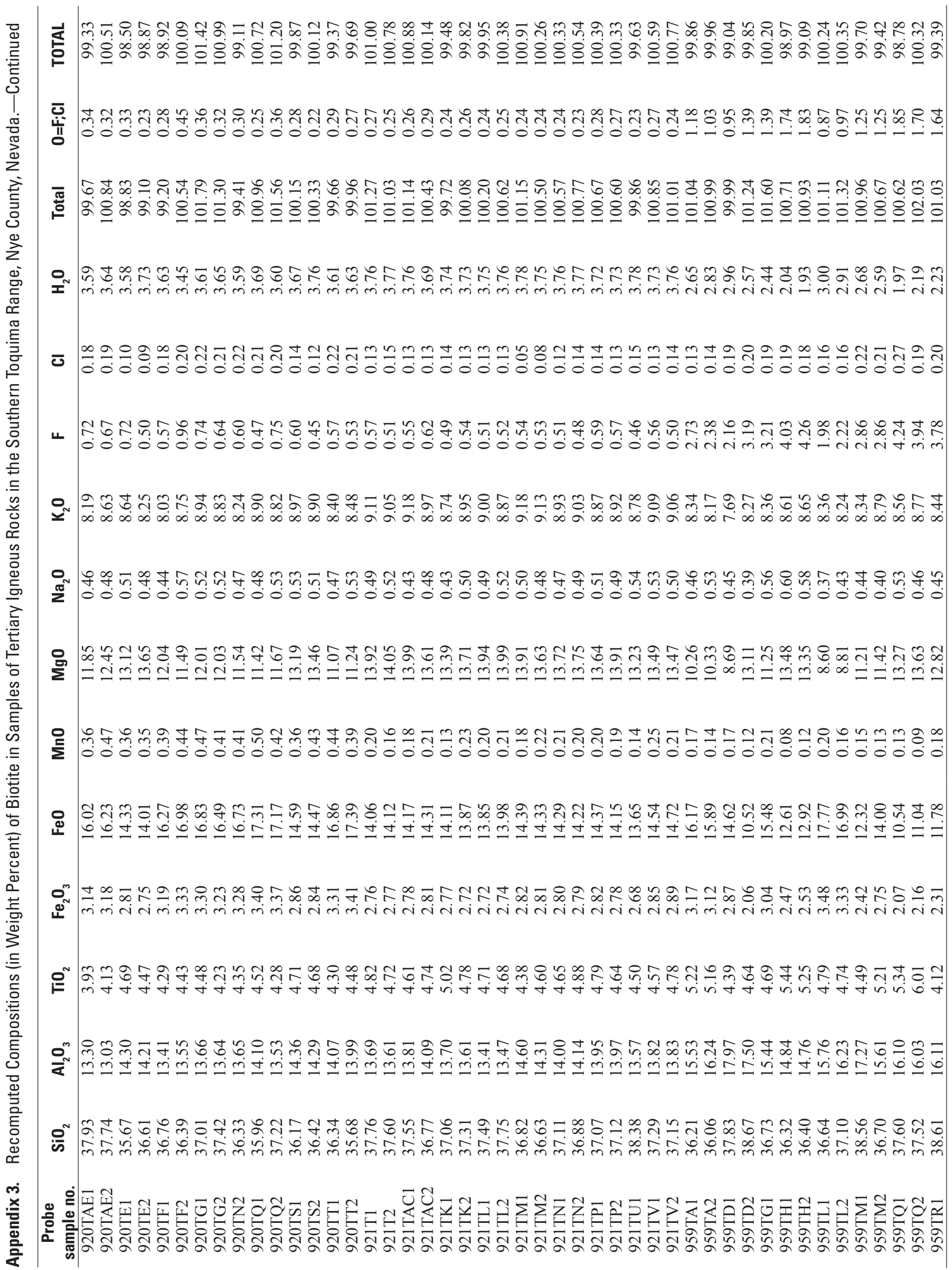





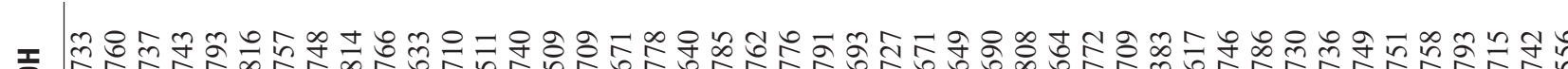

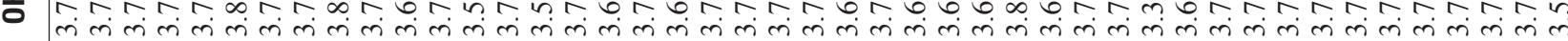

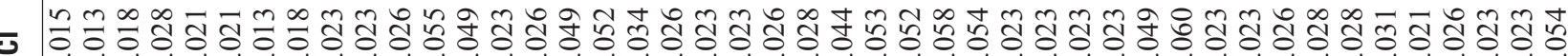

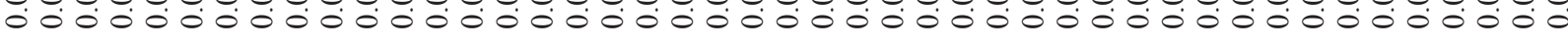

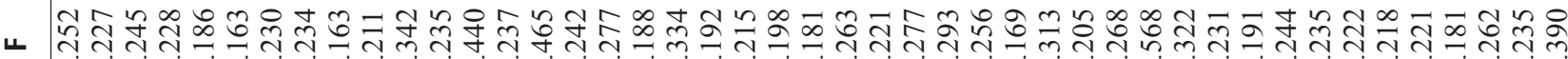

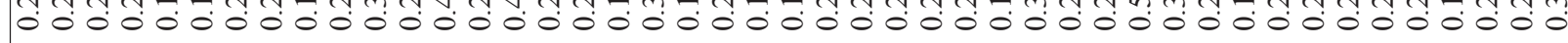

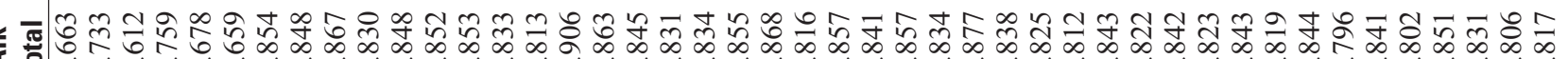

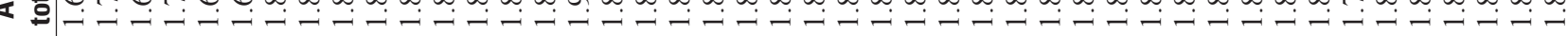

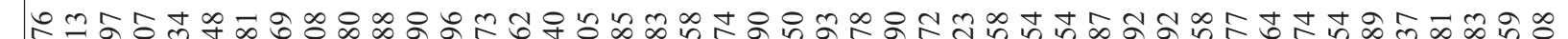
×

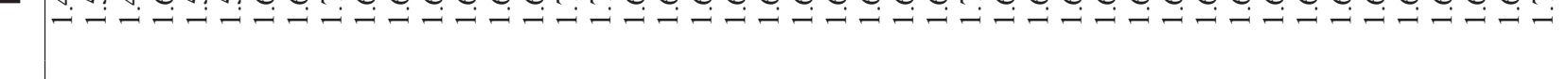

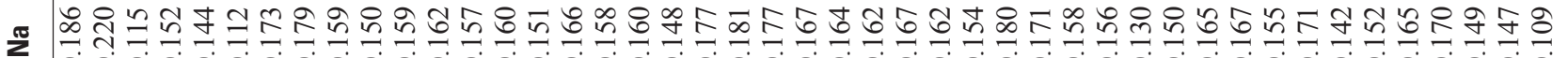

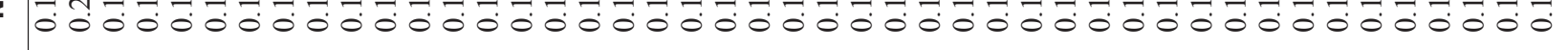

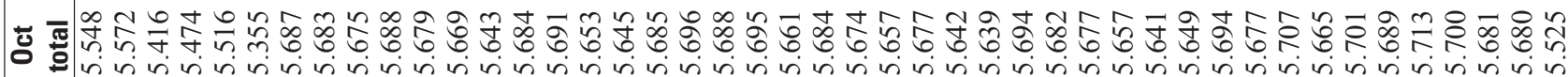

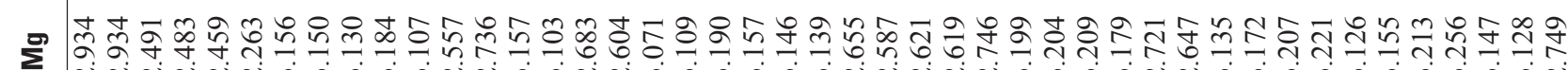

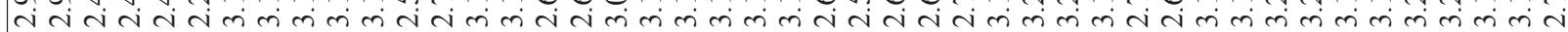

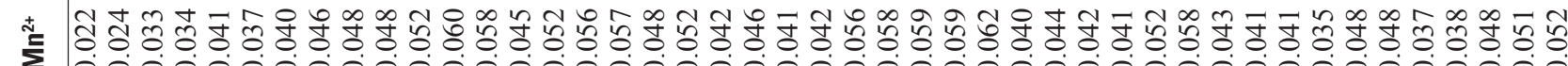

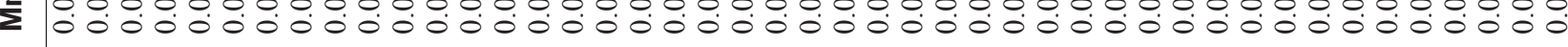

‡ แ

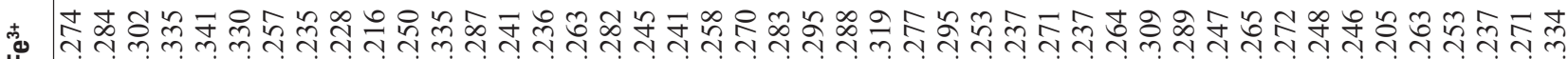

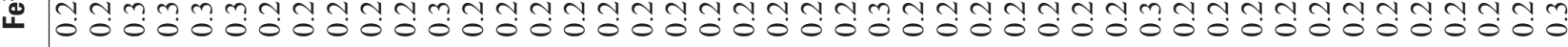

=

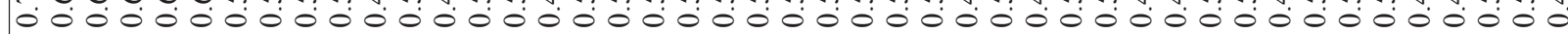

雨

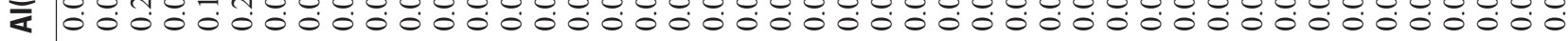

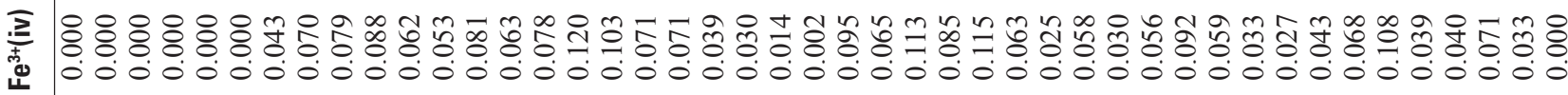

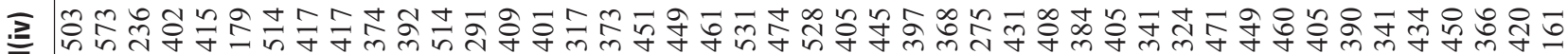

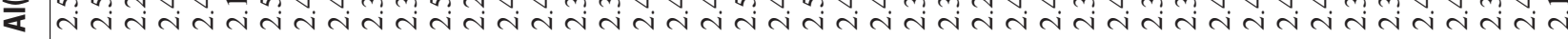

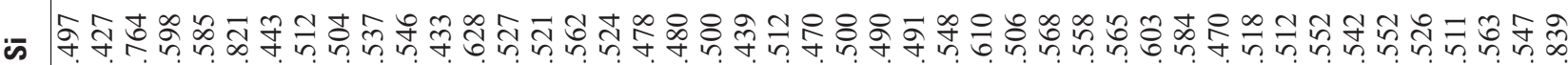

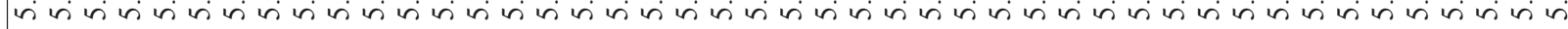

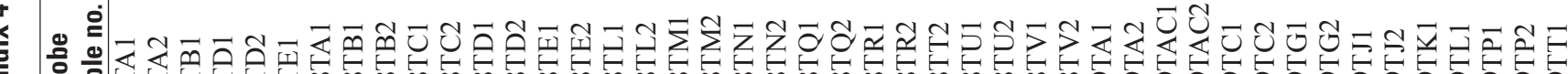

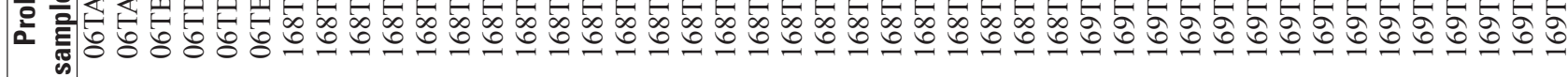




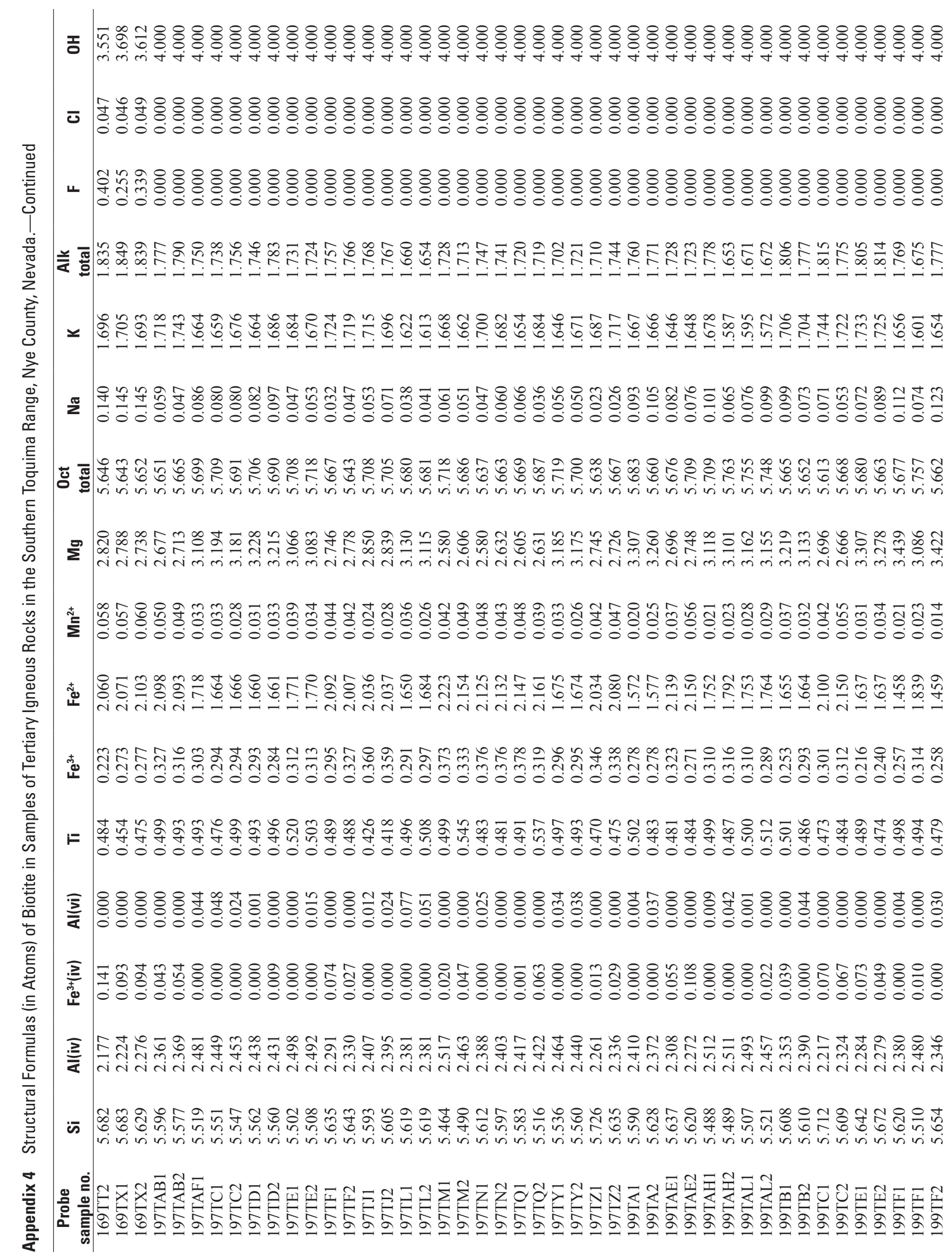




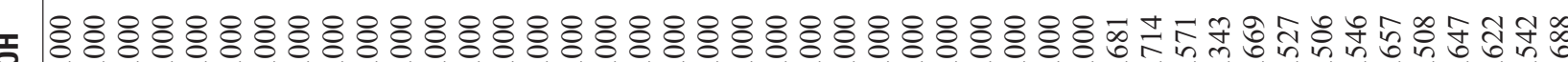

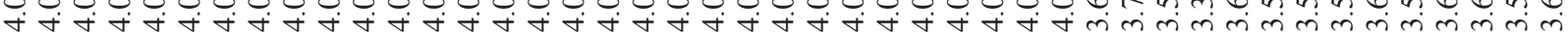

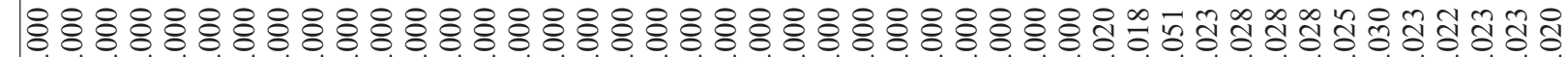
000000000000000000000000000000000000000000000

$\leftarrow$

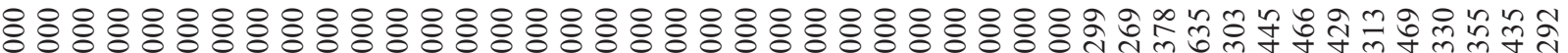
000000000000000000000000000000000000000000000

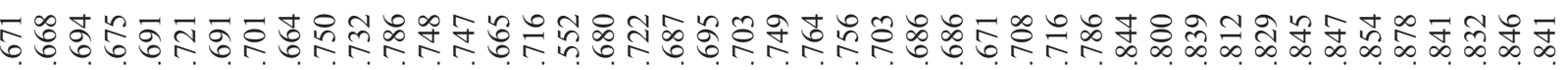

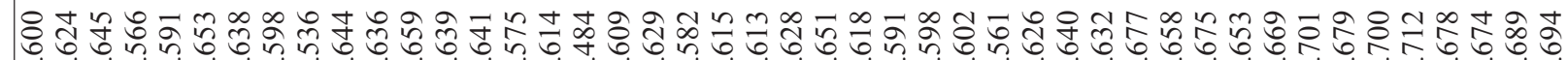
- - - - - - - - - - - - - - - - - - - - - - - - - - - -

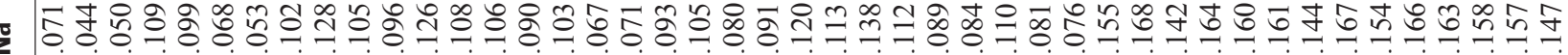

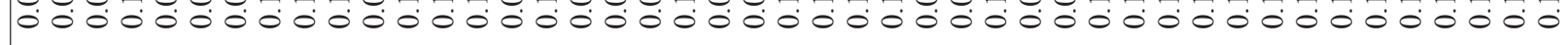

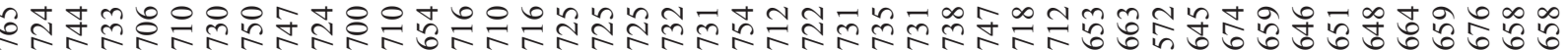

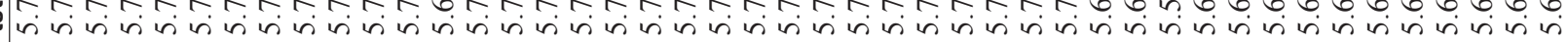

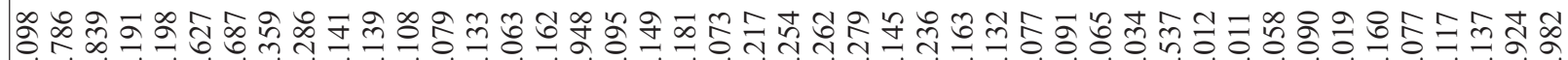

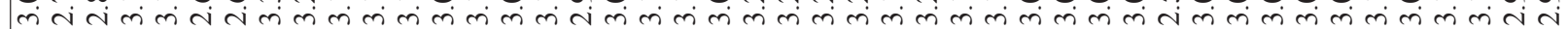

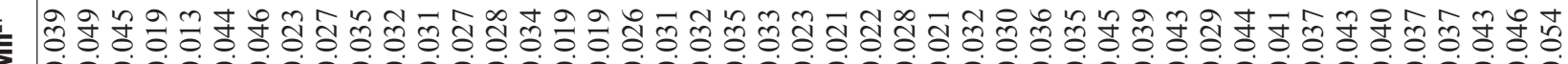
000000000000000000000000000000000000000000000

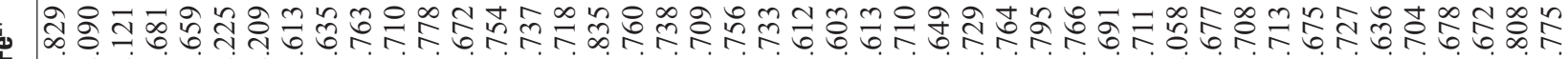
向

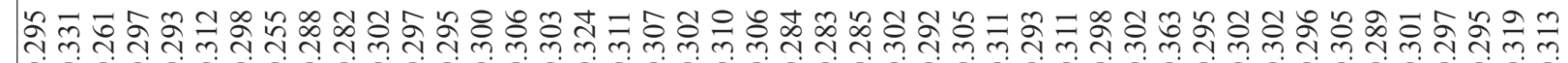

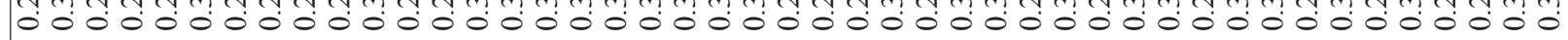

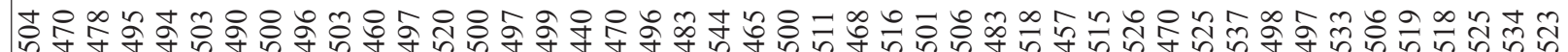
000000000000000000000000000000000000000000000

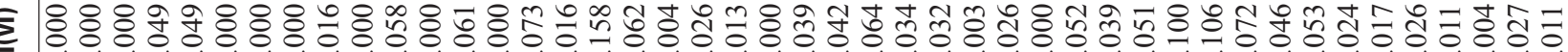
000000000000000000000000000000000000000000000

\%

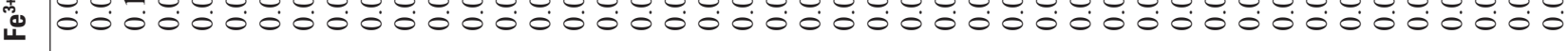

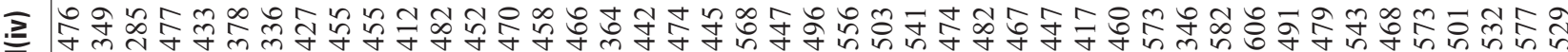

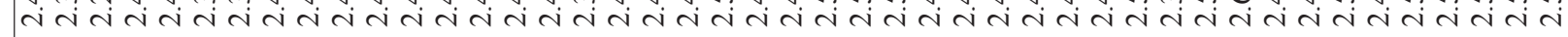

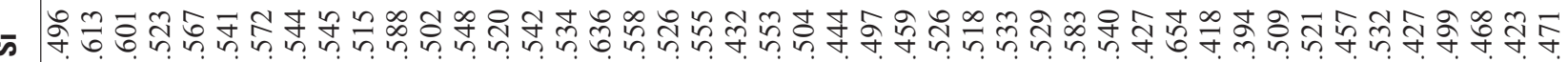

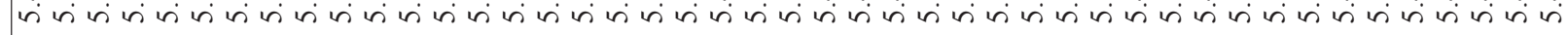

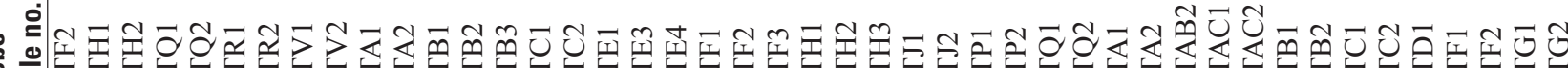

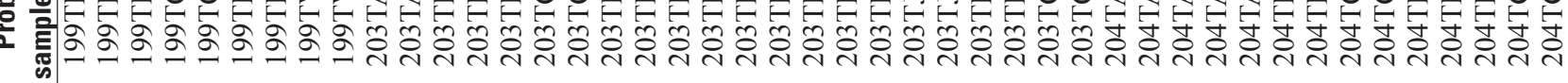


工 $\mid \begin{aligned} & 2 \\ & \infty\end{aligned}$

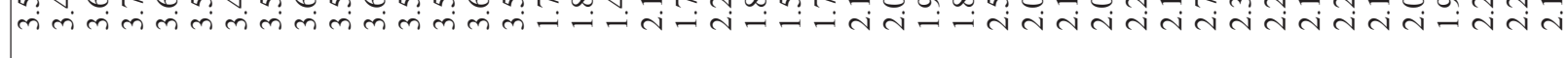

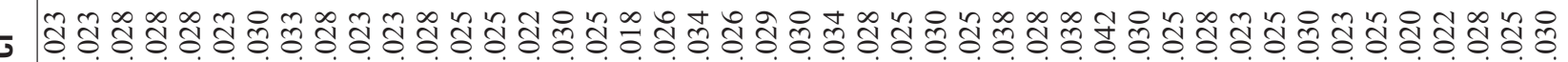

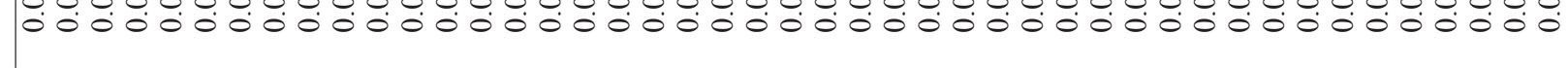

- $\begin{aligned} & \infty \\ & \infty \\ & m\end{aligned}$

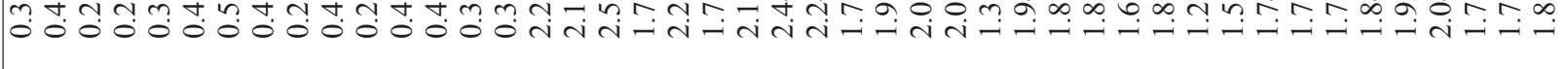

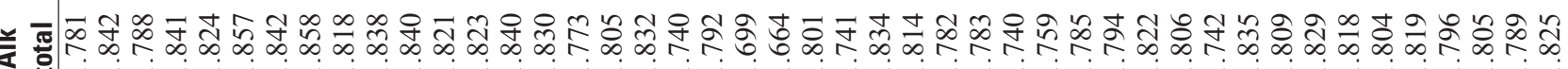

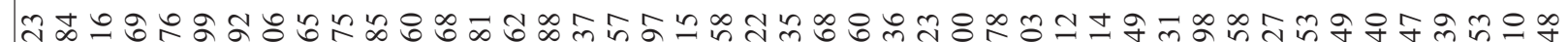
-

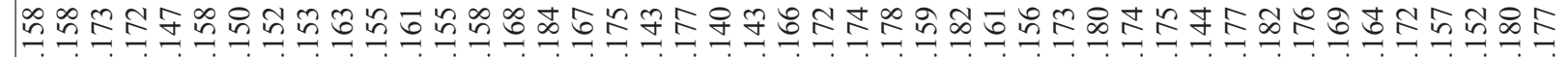
2 o

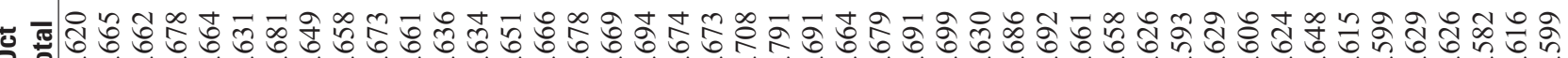

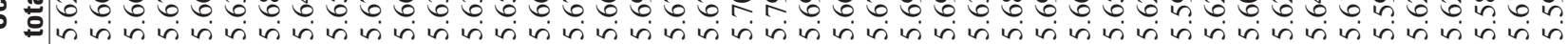

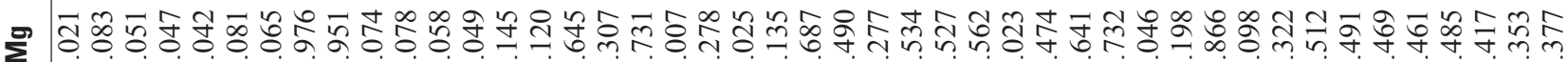

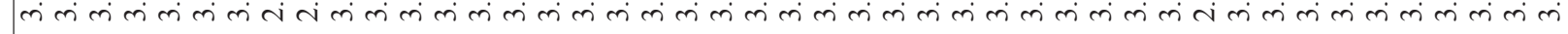

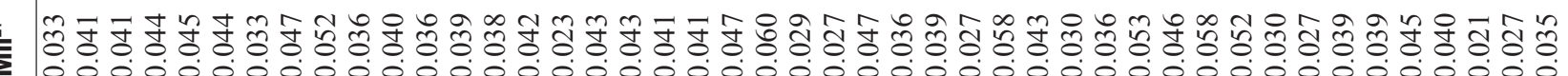
000000000000000000000000000000000000000000000

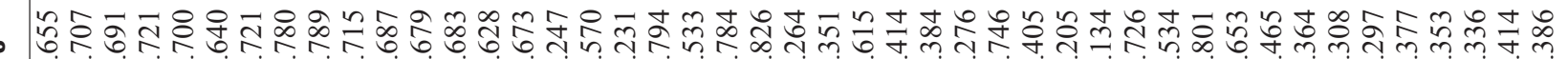

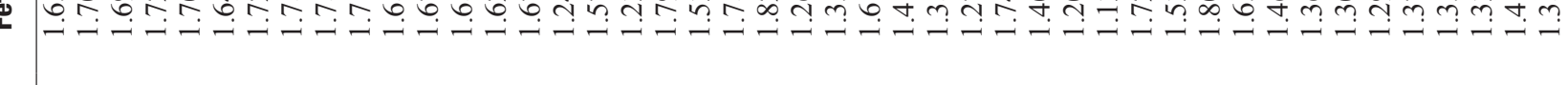

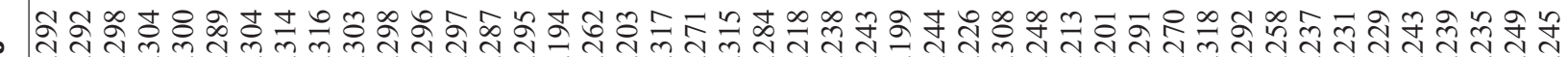

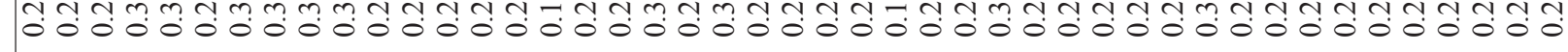

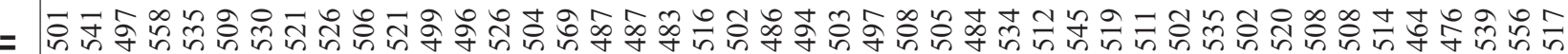
000000000000000000000000000000000000000000000

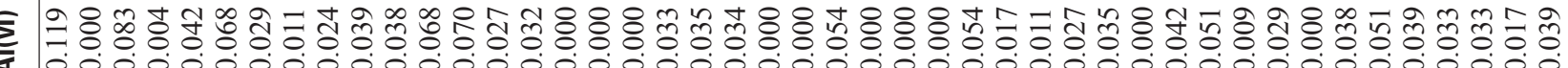
00000000000000000000000000000000000000000000000

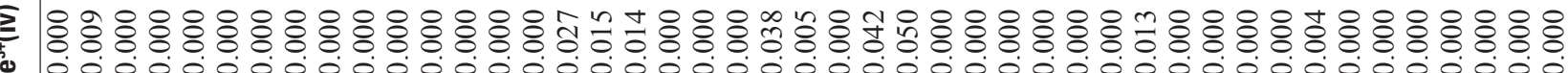
4 0.000000000000000000000000000000000000000000000

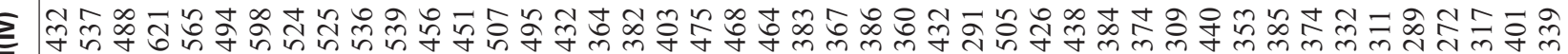

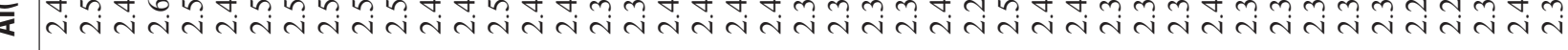

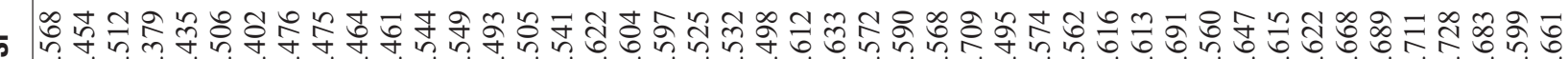

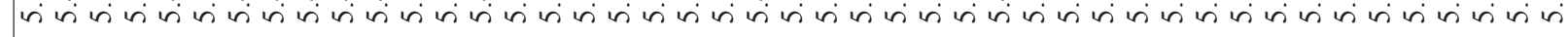

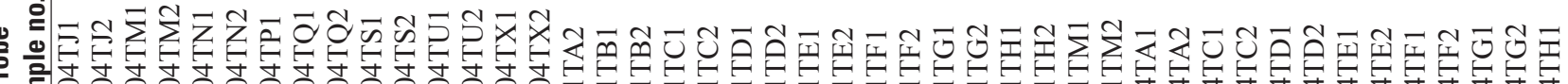

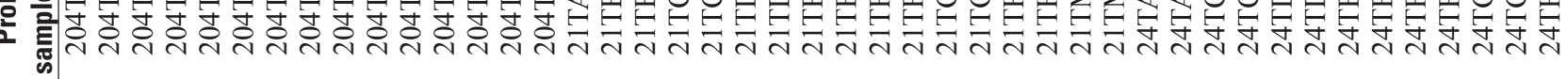




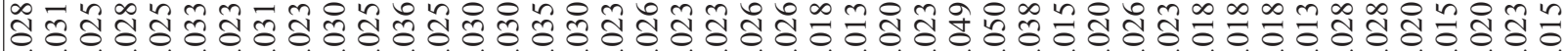

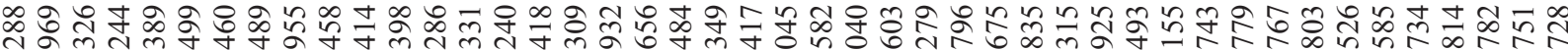
तं

$\leftarrow$

బ -i-ion-

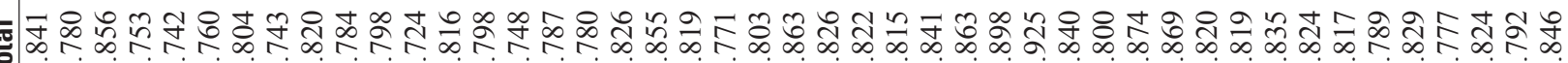

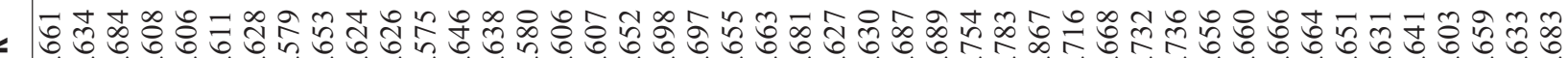

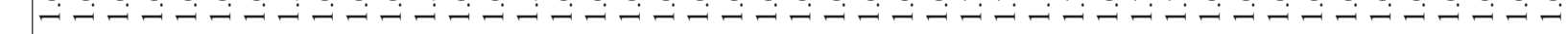

-

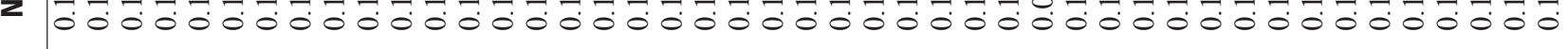

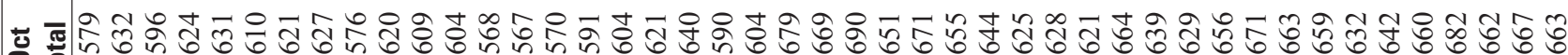

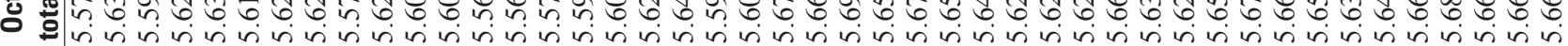

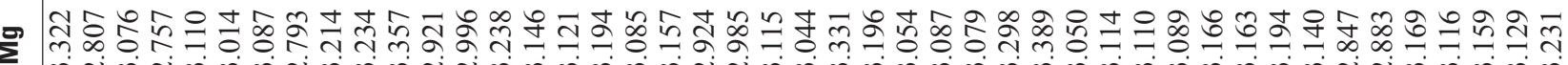

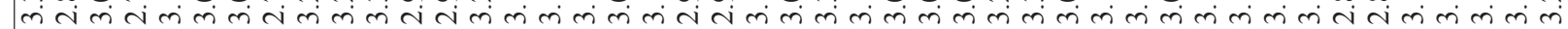

t.

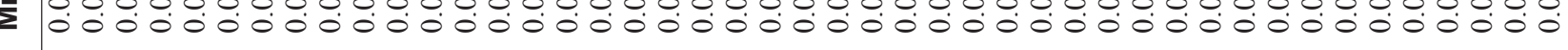

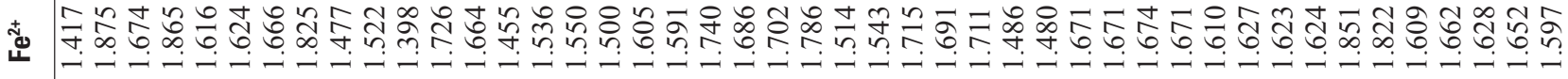

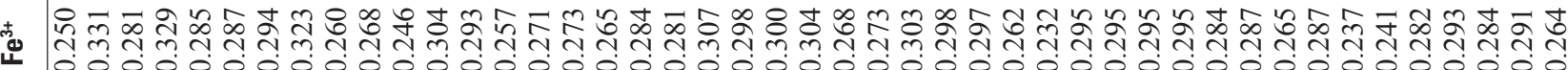

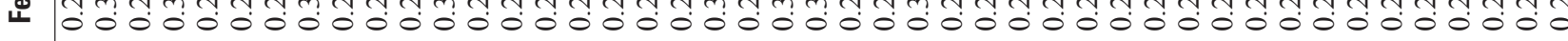

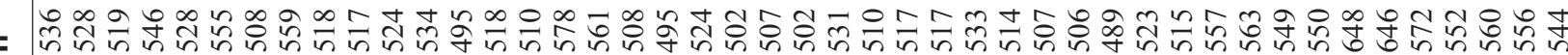

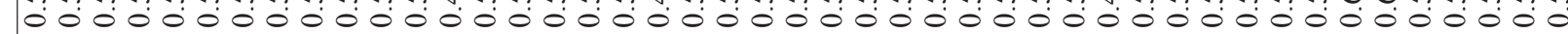

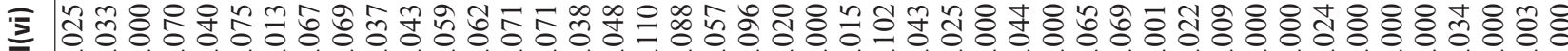

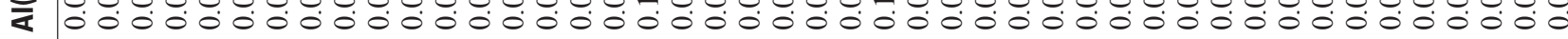

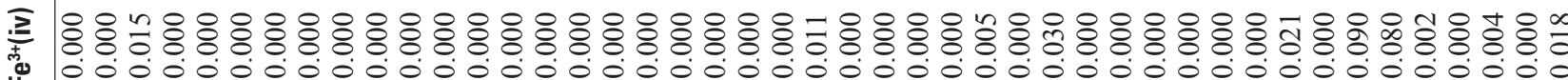

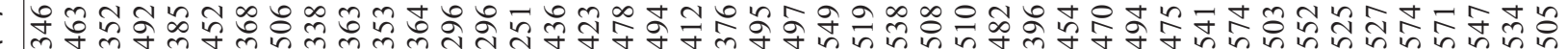

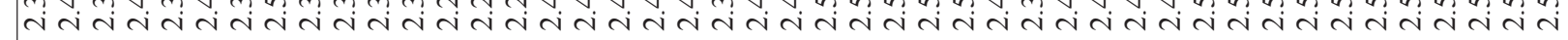

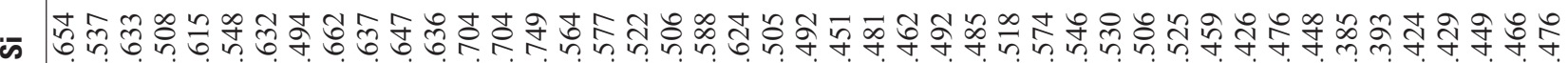

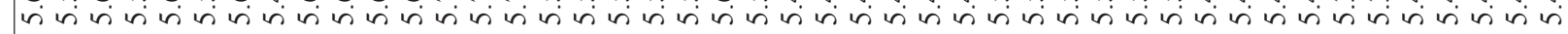




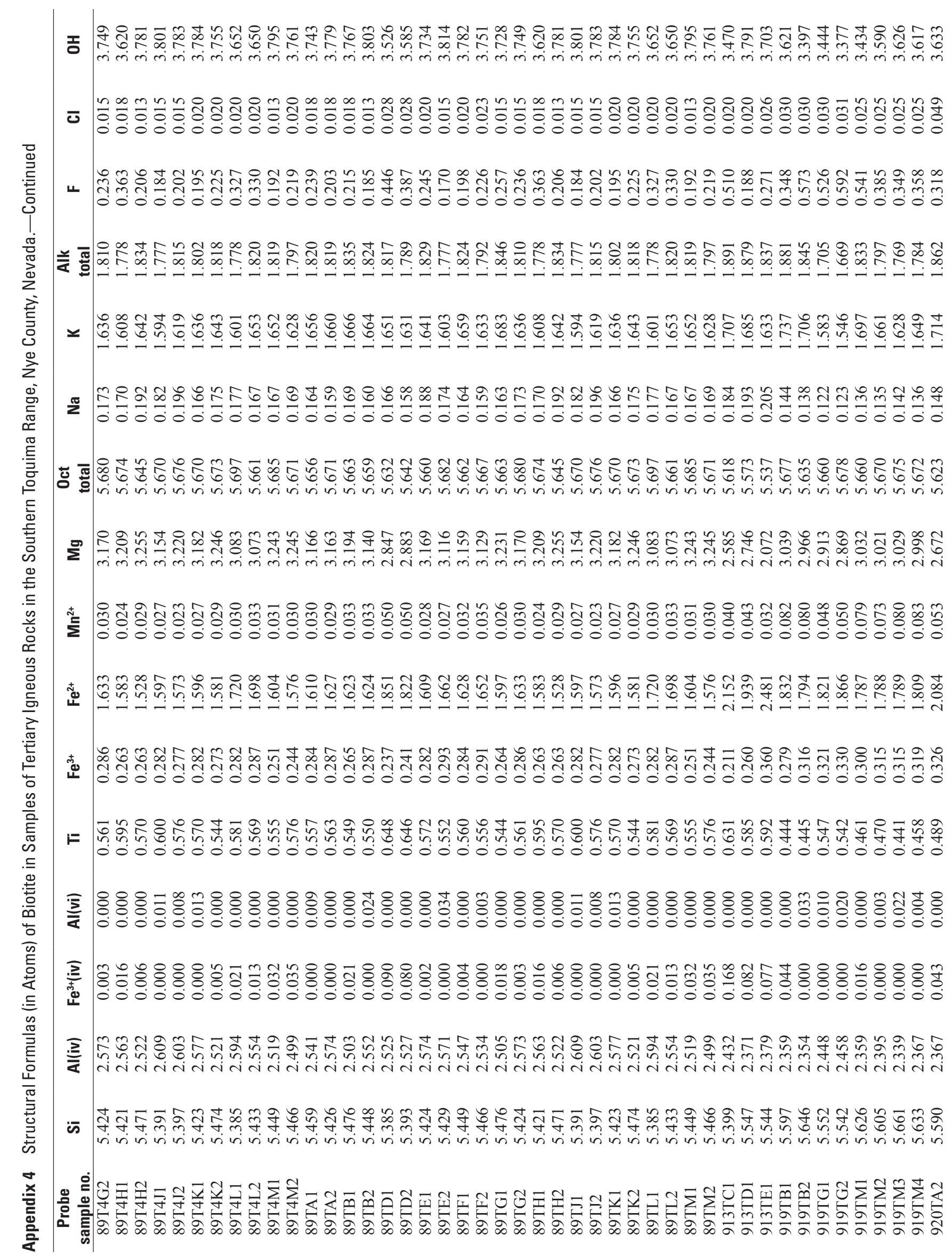


동 药

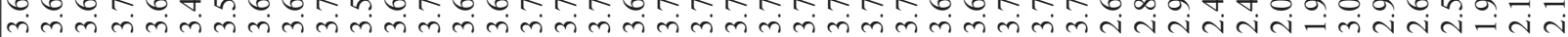

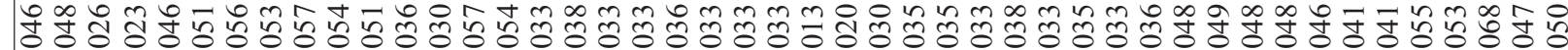

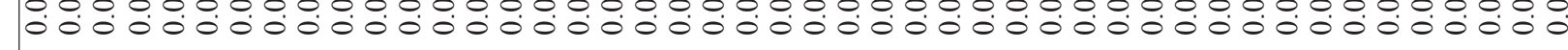

ᄂ

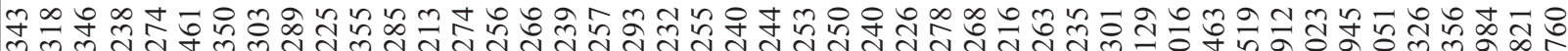
$00000000000000000000000000000000-1-4-4$ i.

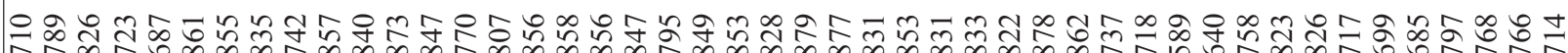

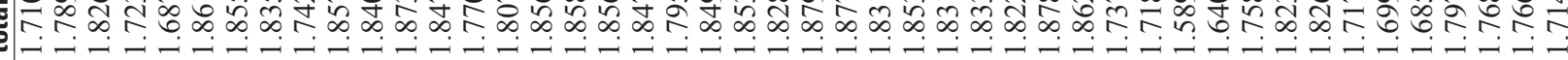

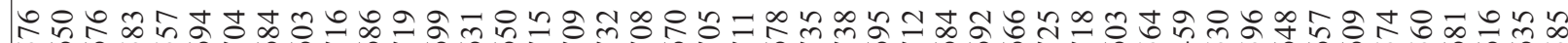

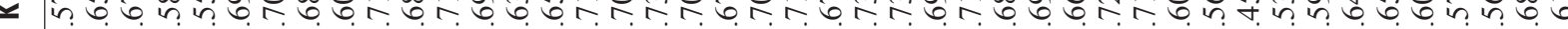

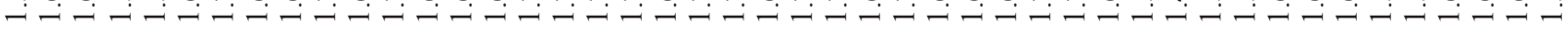

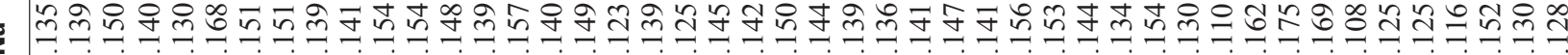

0000000000000000000000000000000000000000000000

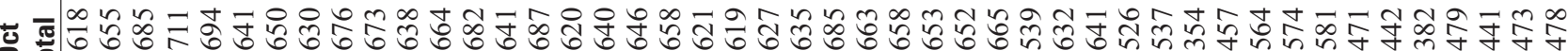

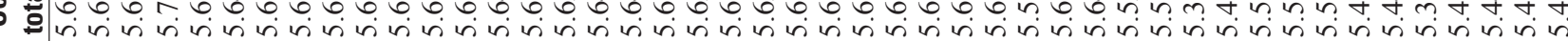

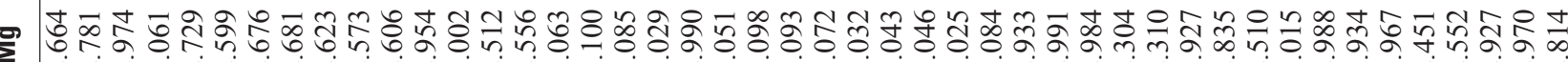

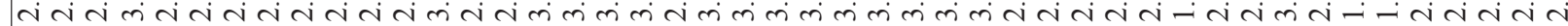

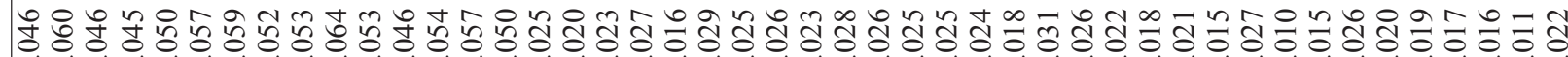
0000000000000000000000000000000000000000000000

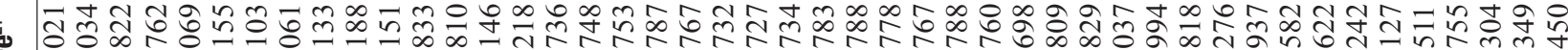

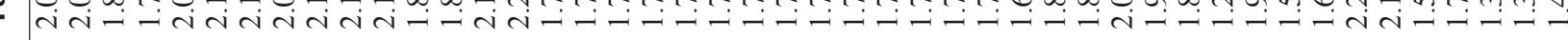

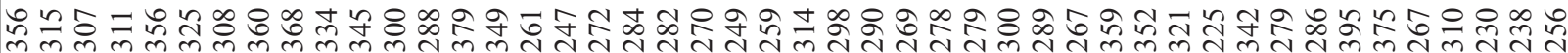
४

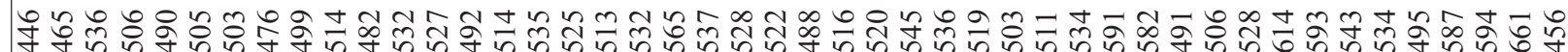

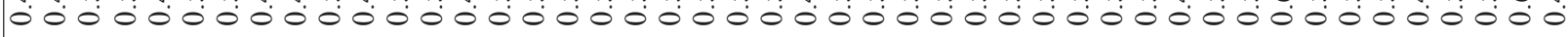

ڤ 000000000000000000000000000000000000000000000000

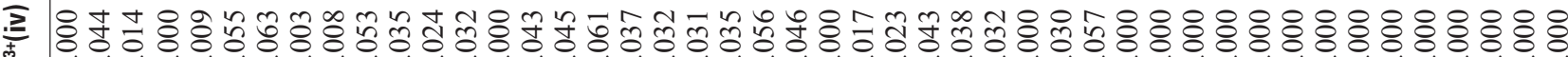
琶 0.000000000000000000000000000000000000000000000

훙ํㅇ त

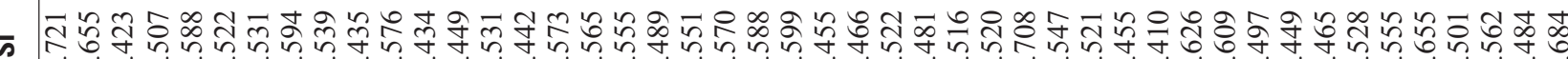

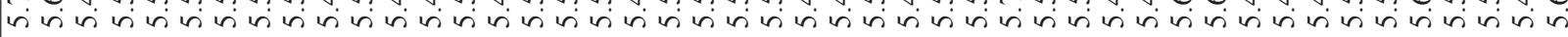

히도

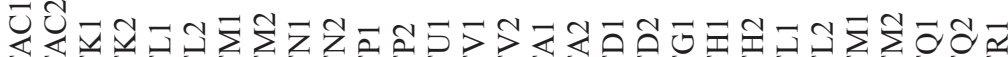

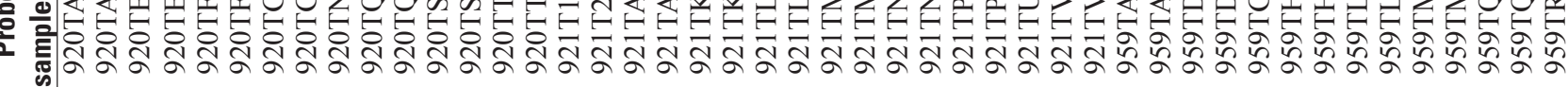



๘

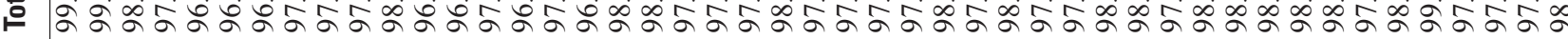

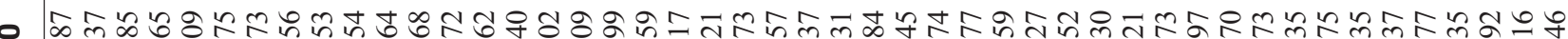
远

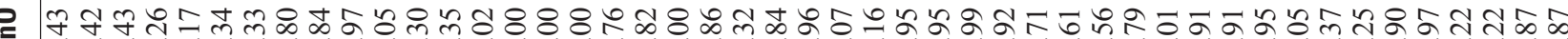

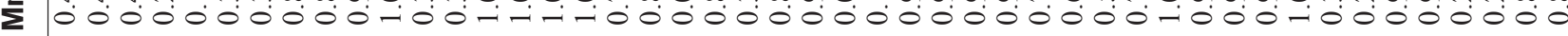

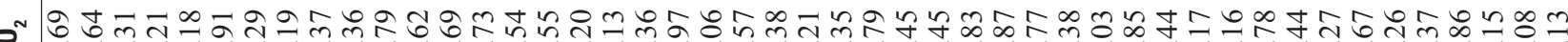

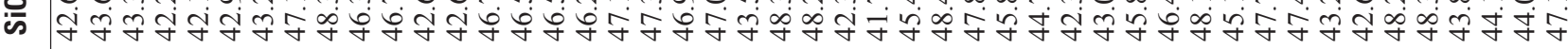

om :

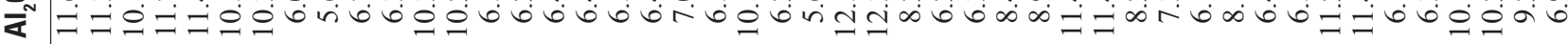

o

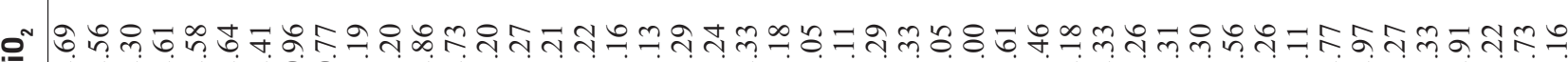

샛त

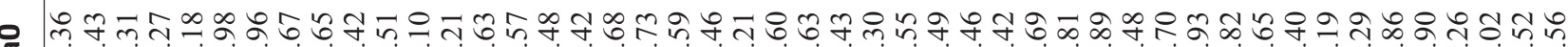
đI

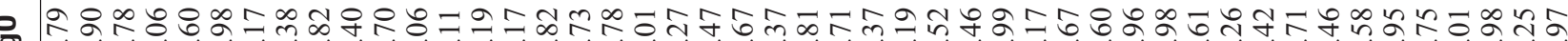

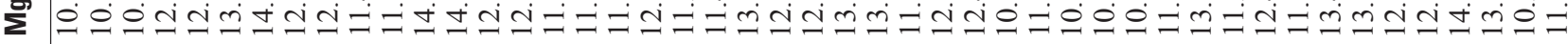

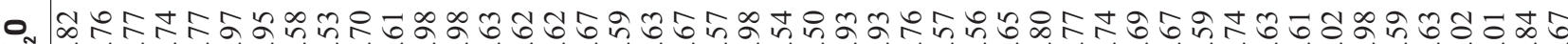

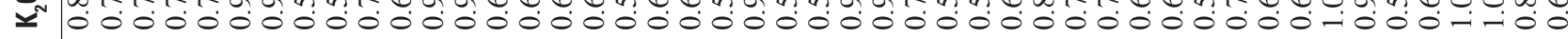

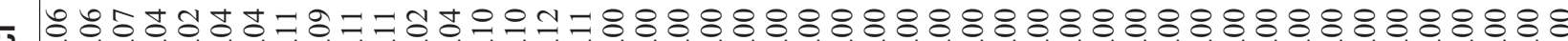
u 0.000000000000000000000000000000000000000000000

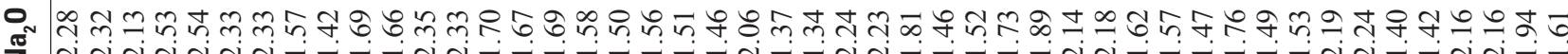

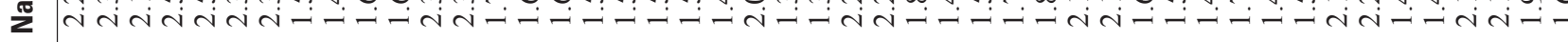

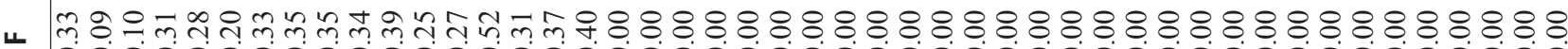
0000000000000000000000000000000000000000000000000

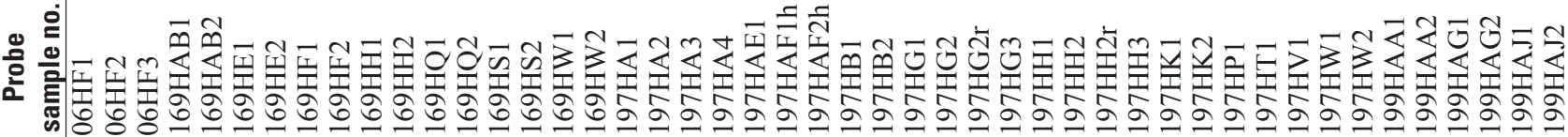

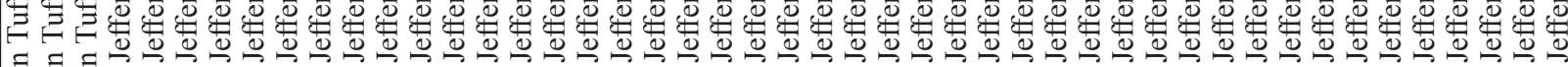

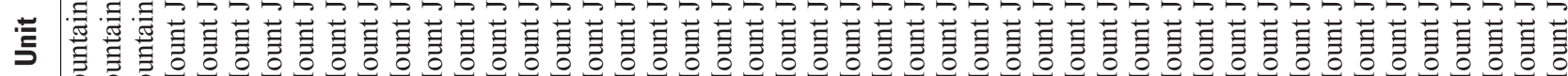

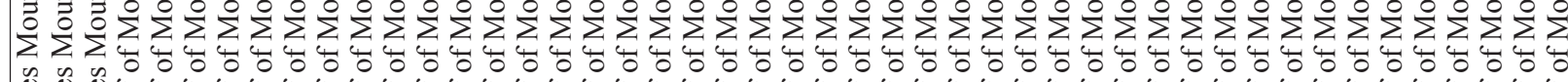

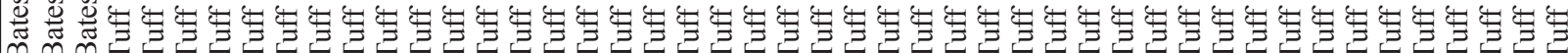

-

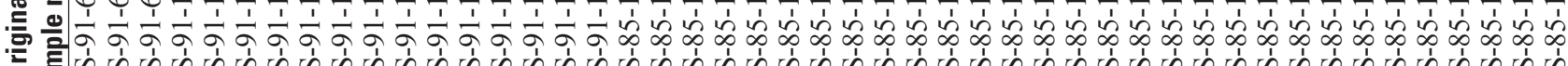




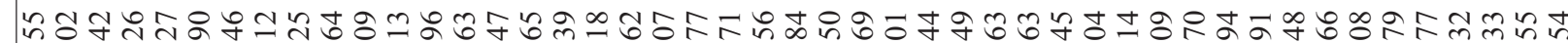

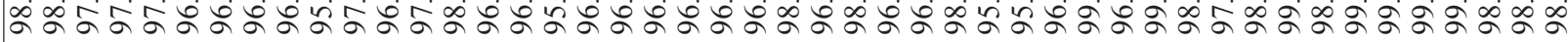

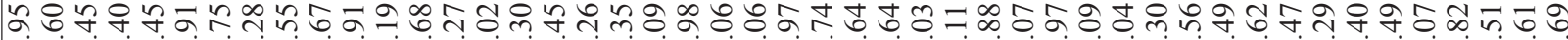

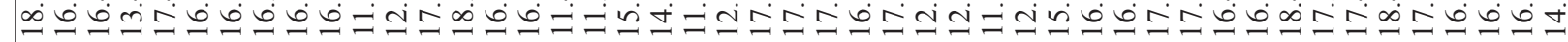

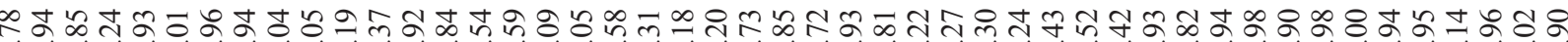
$00000+00-1000000000000000000000000000000400.040$

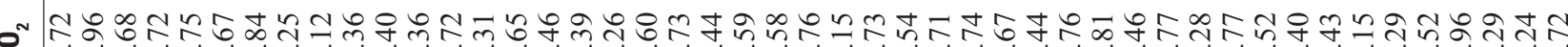

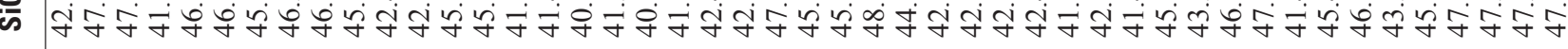

o ๆ

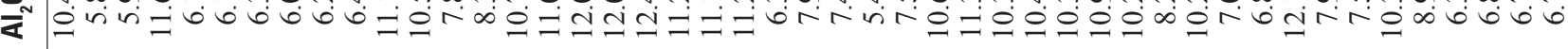

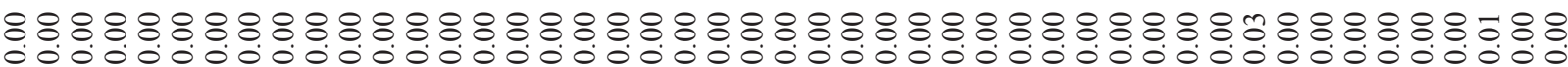

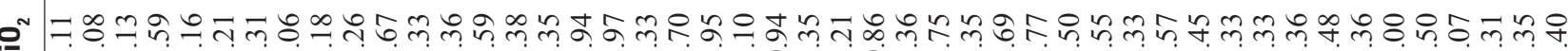

-

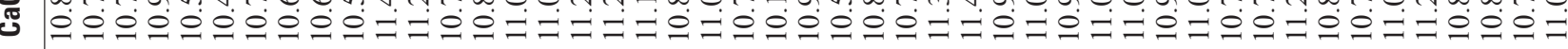

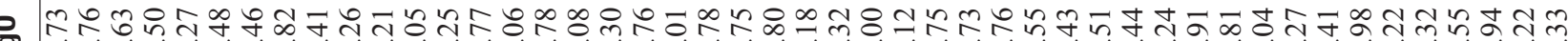
๖

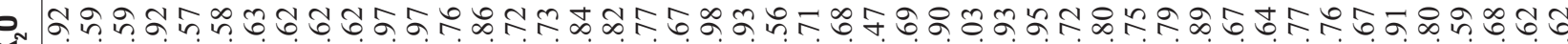
x

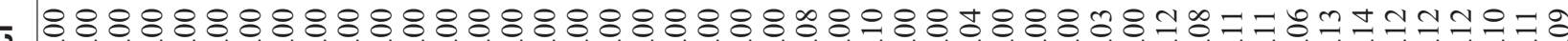
00000000000000000000000000000000000000000000000

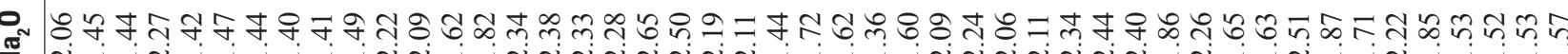

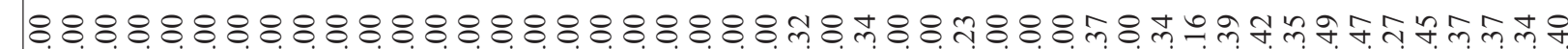

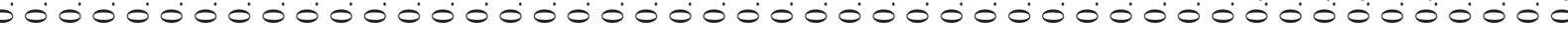

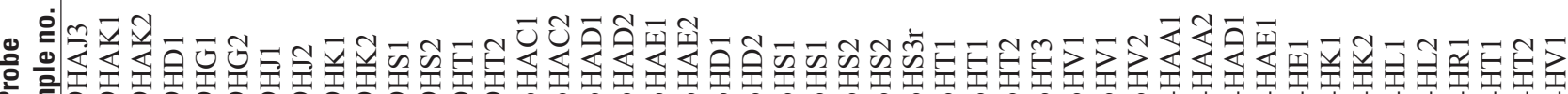

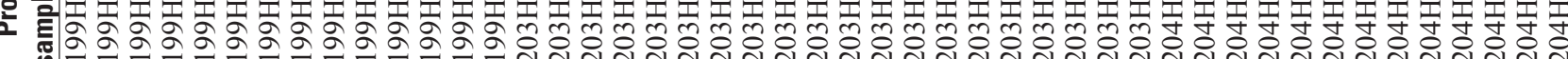

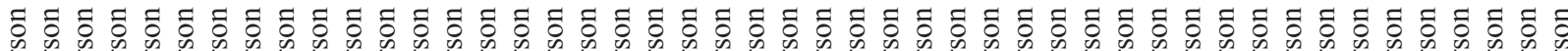

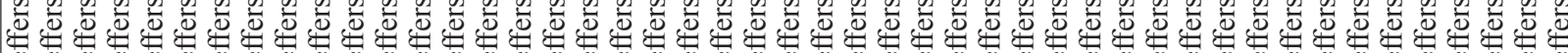

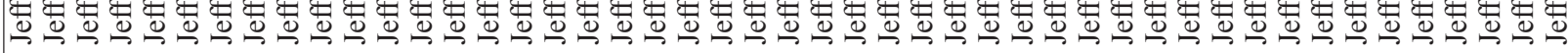

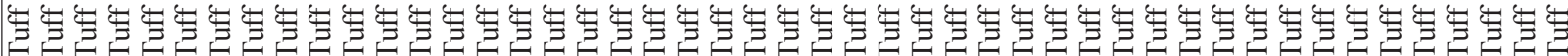




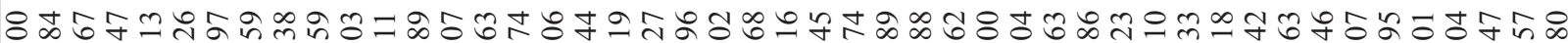

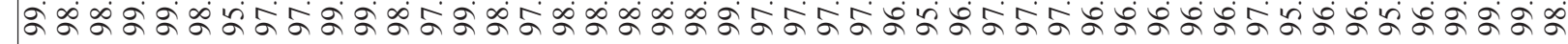

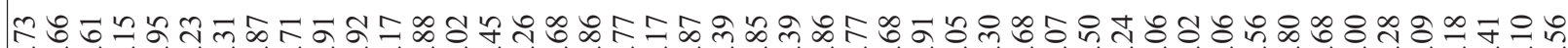

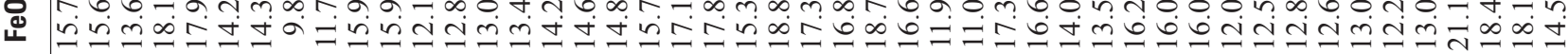

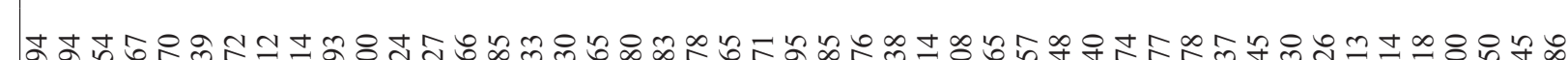

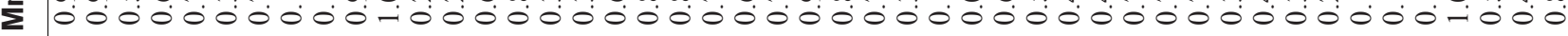

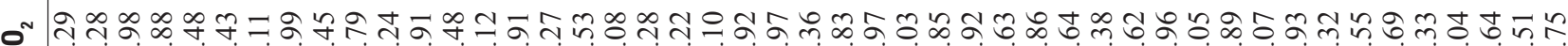

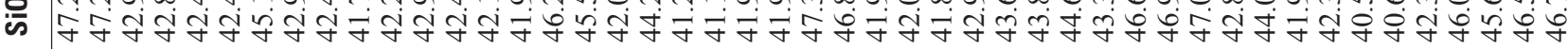

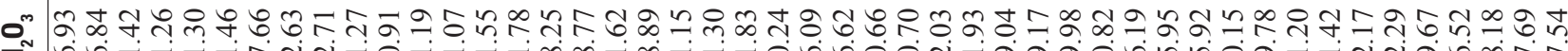
《

o

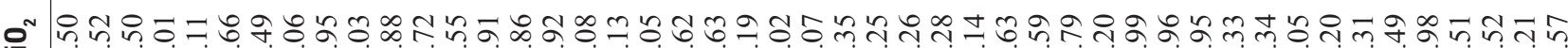

o

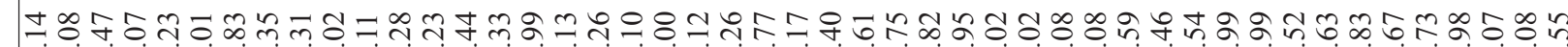

ษ

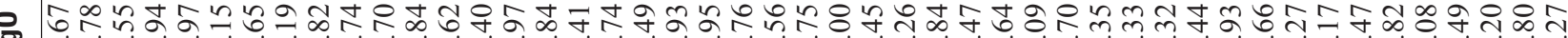

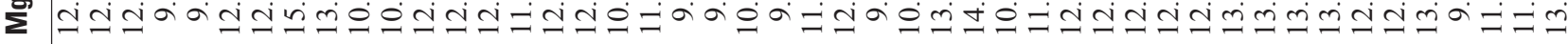

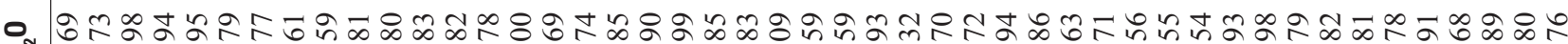

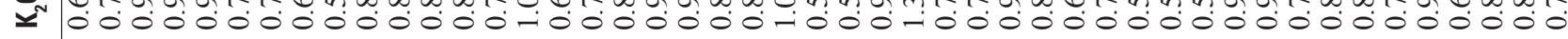

บ

u 0.000000000000000000000000000000000000000000000

유

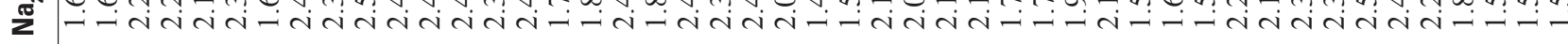

- mे m̄ $000000000-10000-000-10000000000000000000000000000$

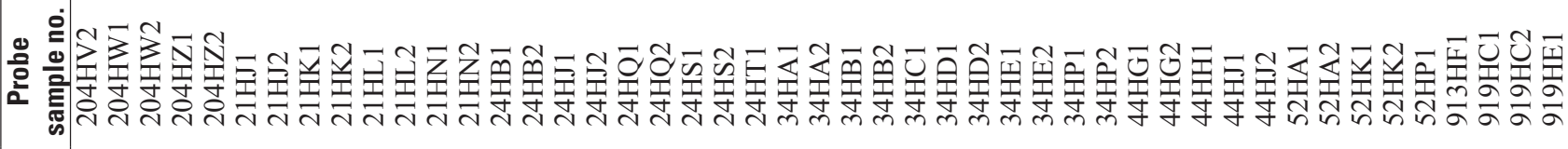

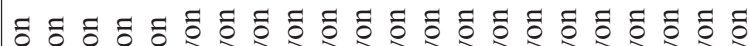

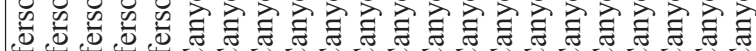

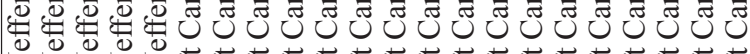

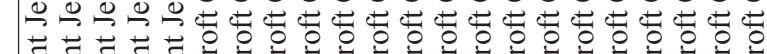

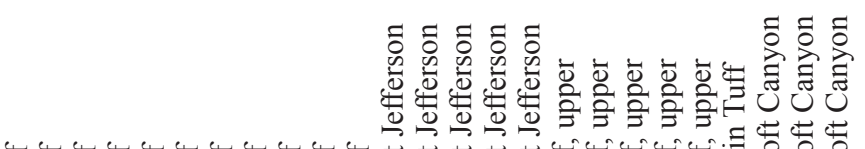

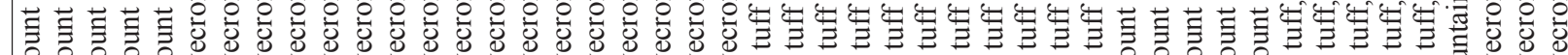
$\sum \sum \sum \sum \sum \sum \sum_{1}$ 4ै

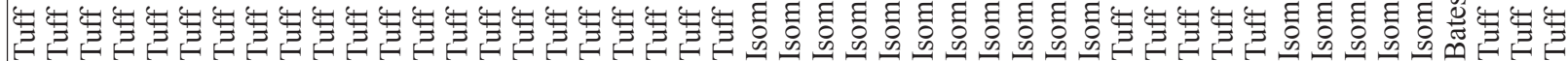


సิm®

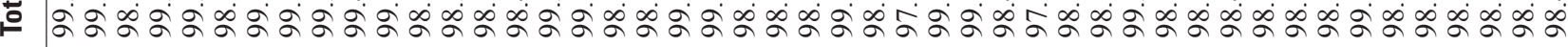

సิ చే 。

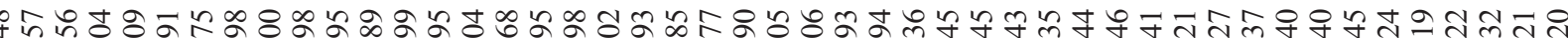

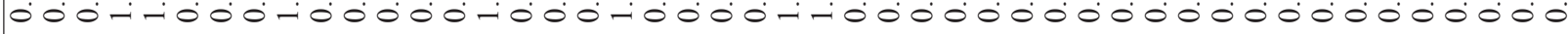

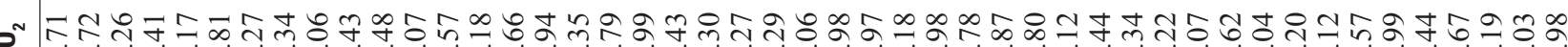

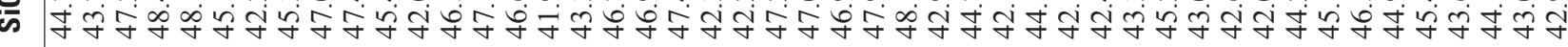

o $\approx a 0 \wedge$ n

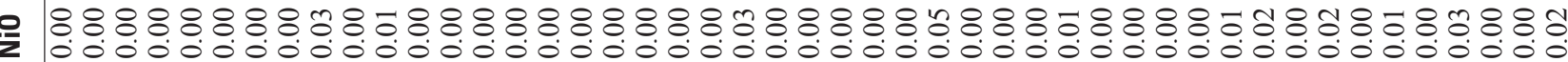

○

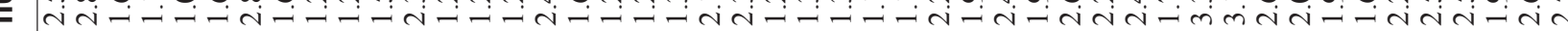

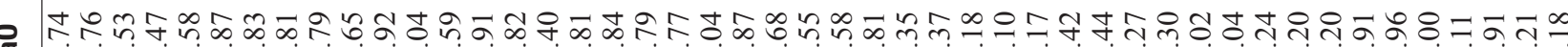
厅

유요 유요요 ๖

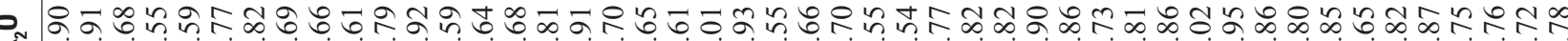
$=00000000000000000000.000000000000000000000000000$

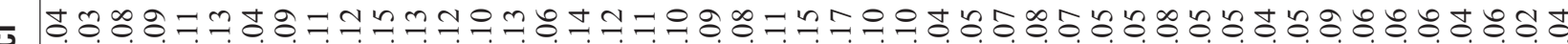
00000000000000000000000000000000000000000000000

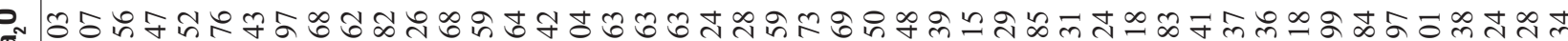
4in-

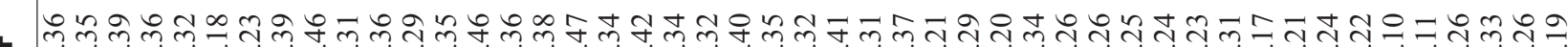

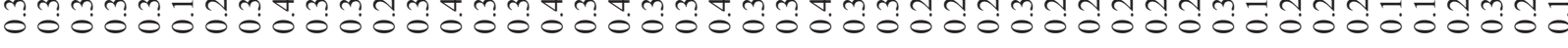

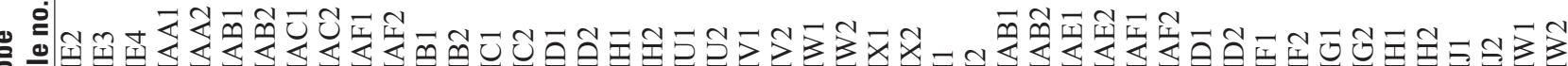
는 "

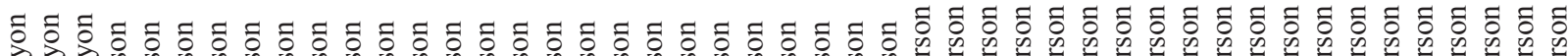

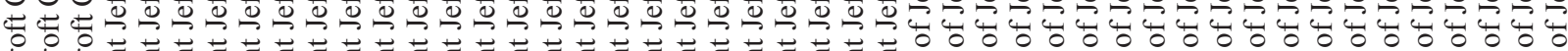

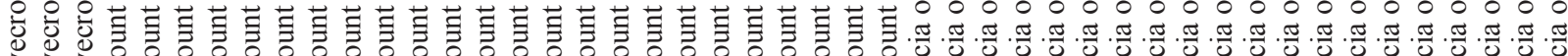

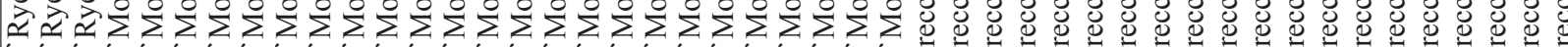

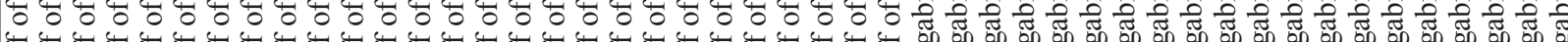

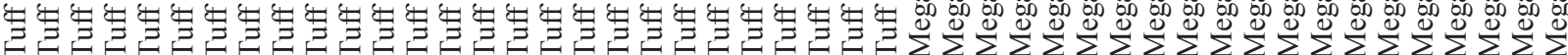




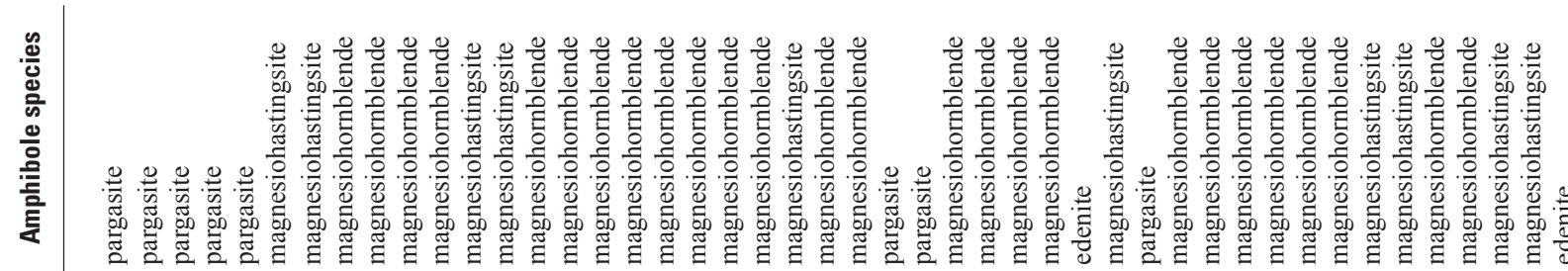

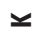

뜬

뜬

తึ

릴

趐

$\Sigma$

离

₹

䓌

$i=$

근

《

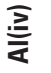

\%

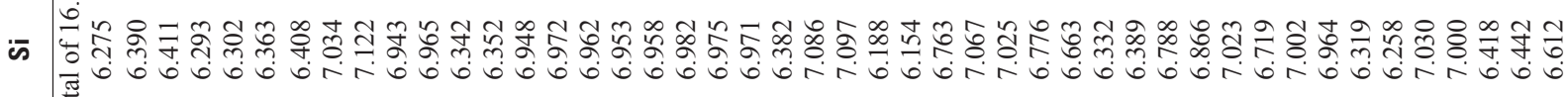
:

홍 흘

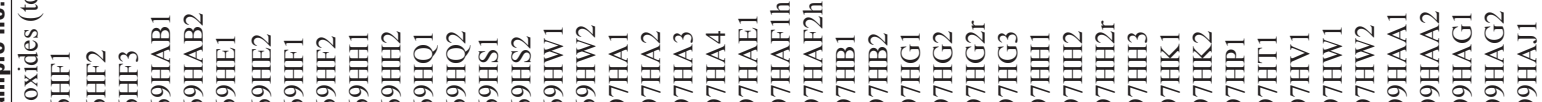

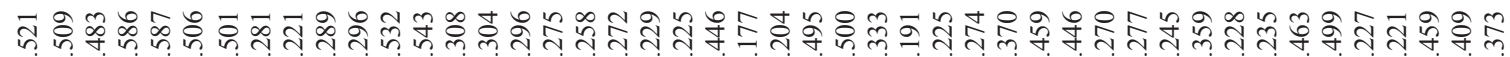

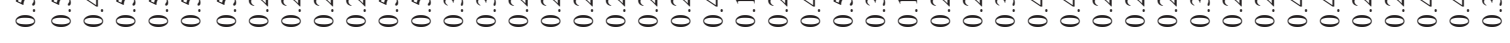

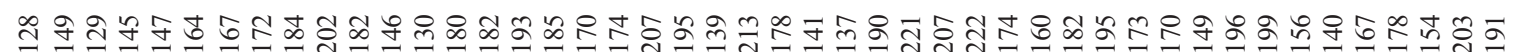

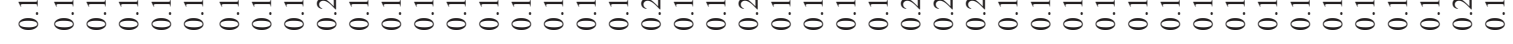

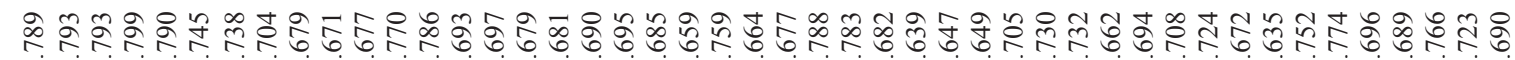

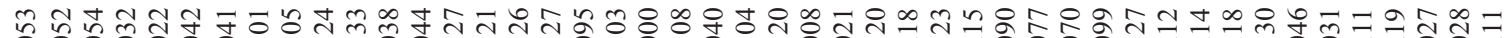
0000000000000000000000000000000000000000000000

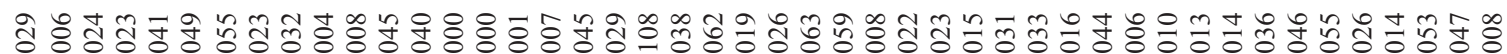
000000000000000000000000000000000000000000000

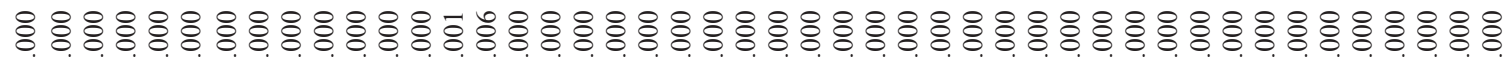

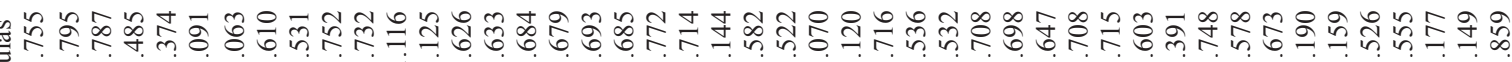

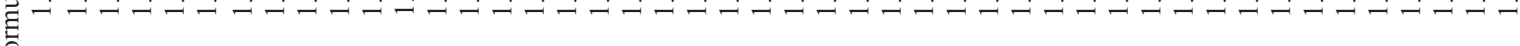

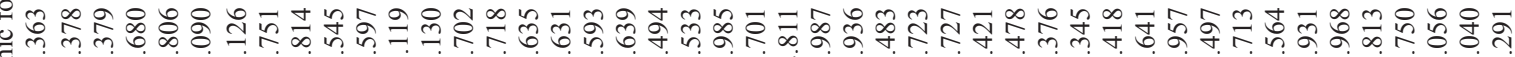

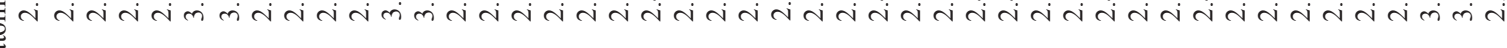

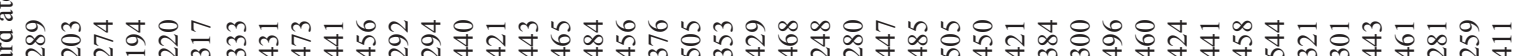

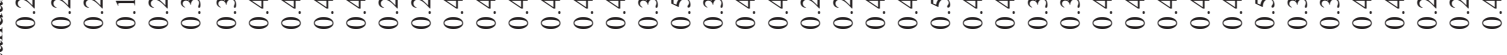

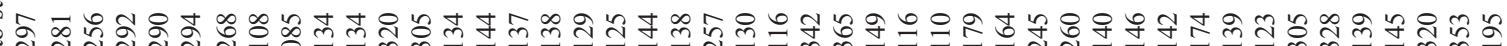
过

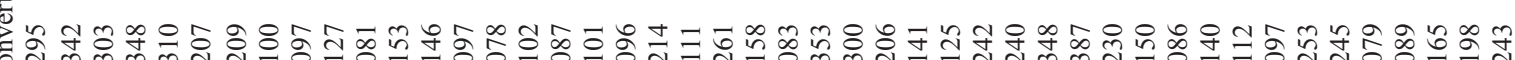
o o00000000000000000000000000000000000000000000 要

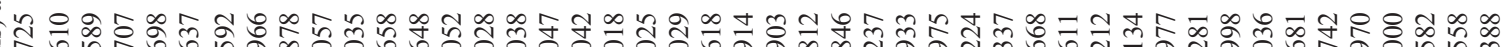

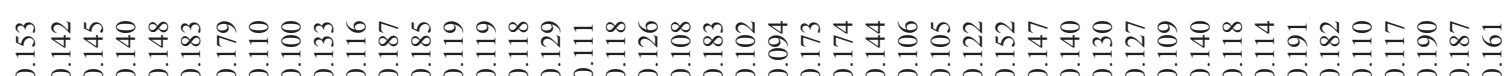
:

วี

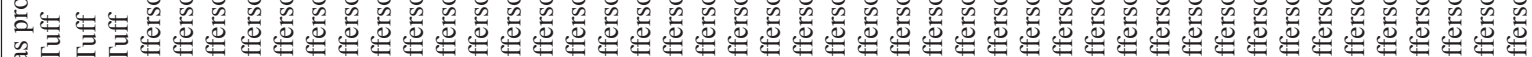

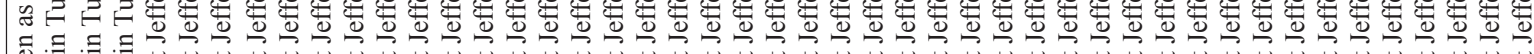

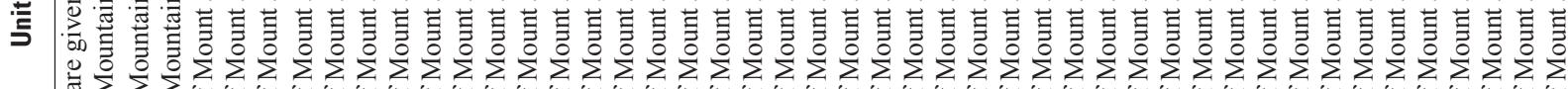

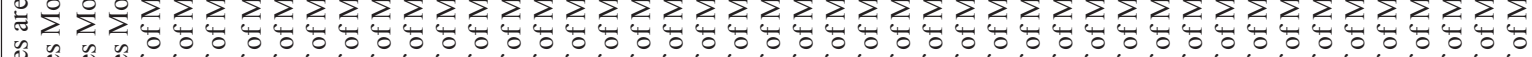

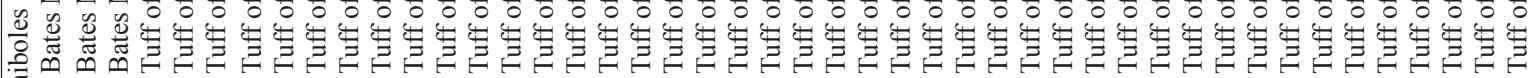
:

س

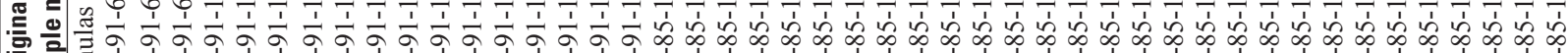
1) 

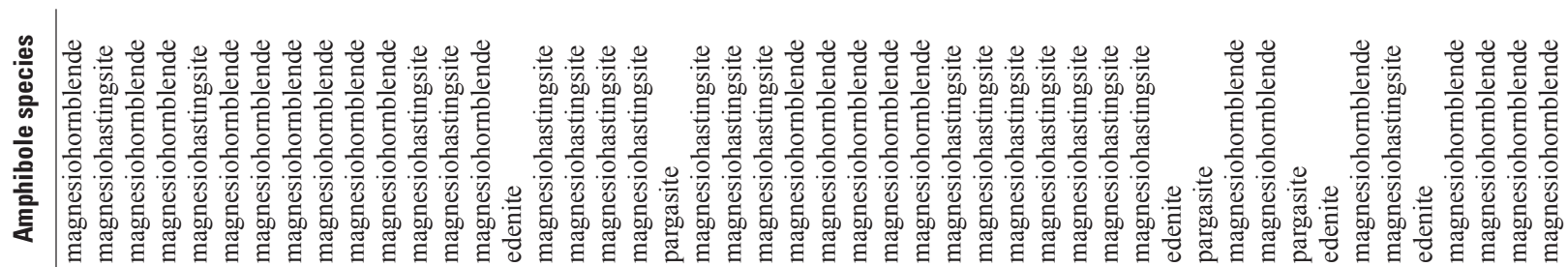

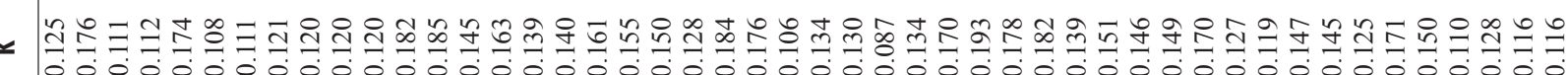

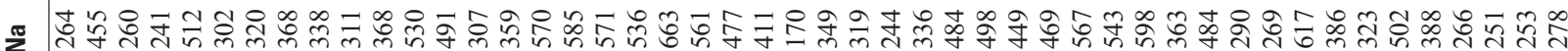

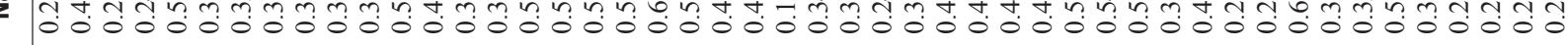

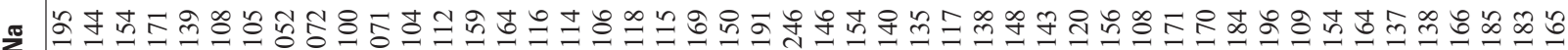

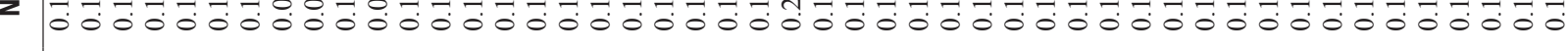

đ

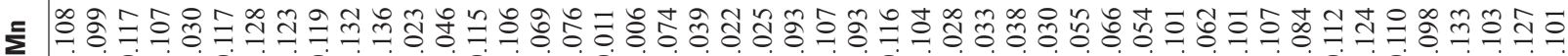
ț 0000000000000000000000000000000000000000000

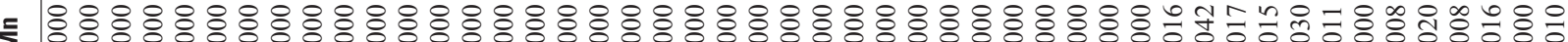
I 离

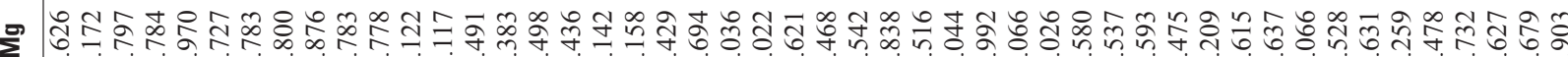

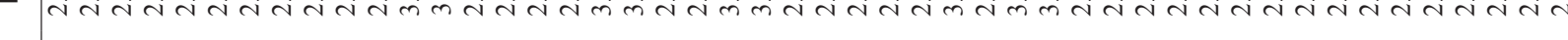

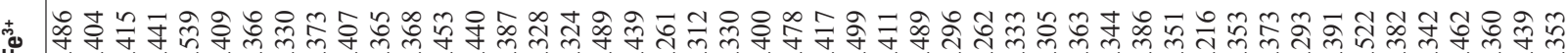

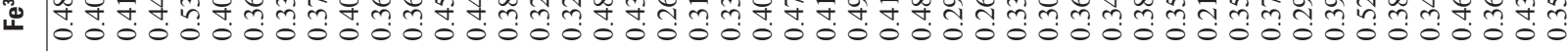

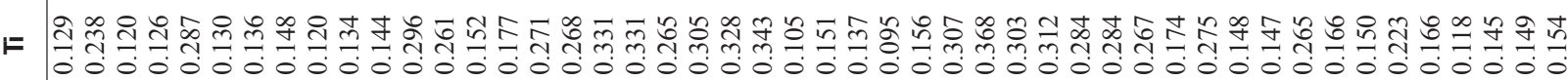

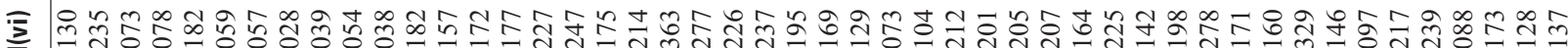

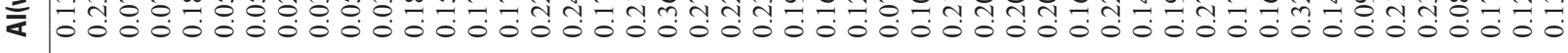
产

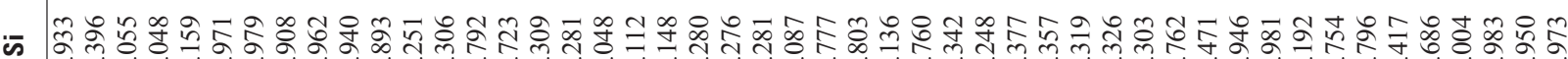
b or

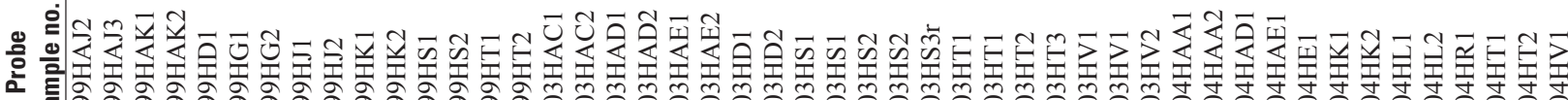

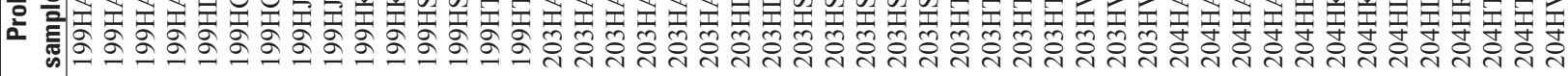

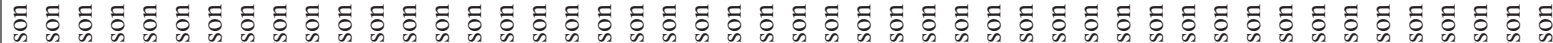

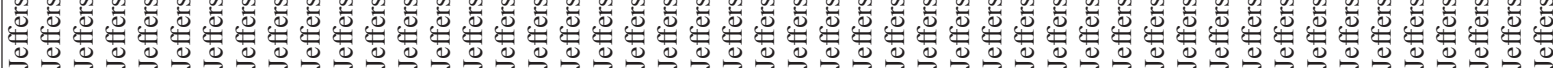

豆

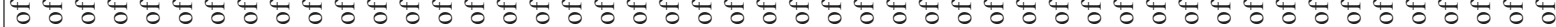

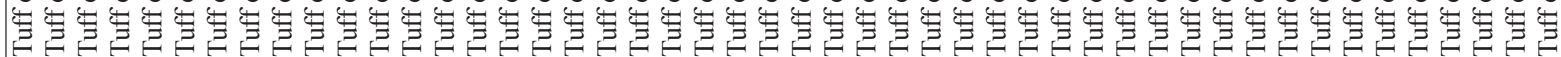




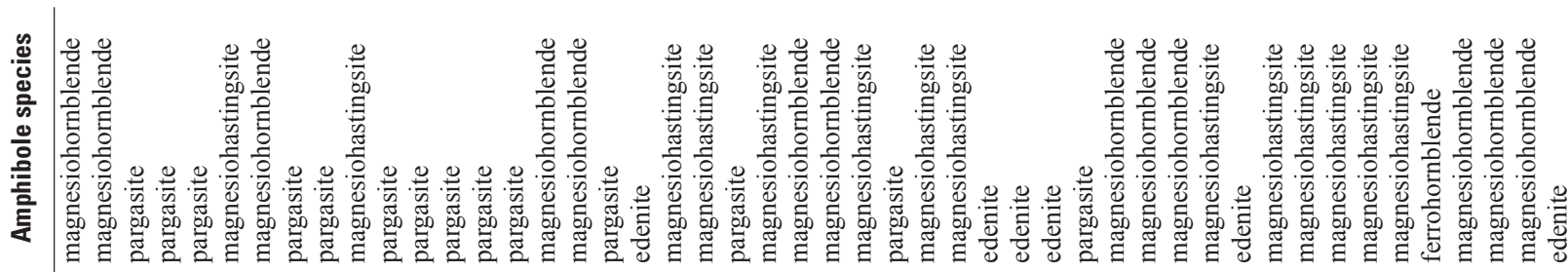

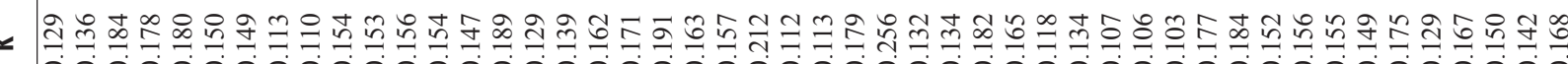

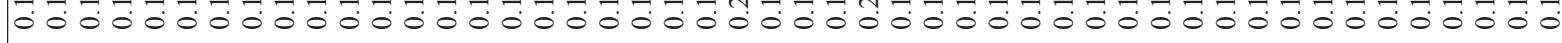

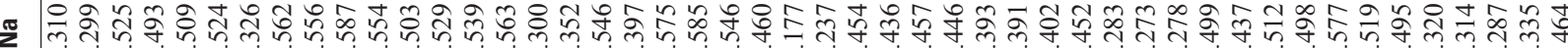

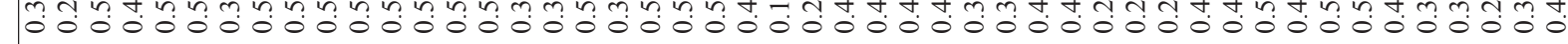

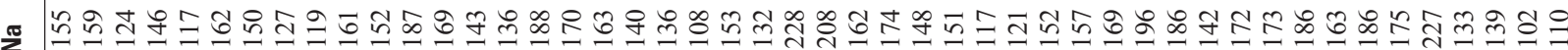
000000000000000000000000000000000000000000000000 đᄄ

- Кำ

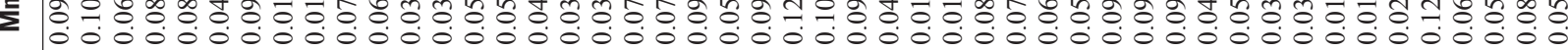

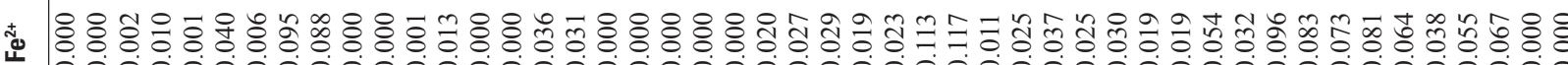

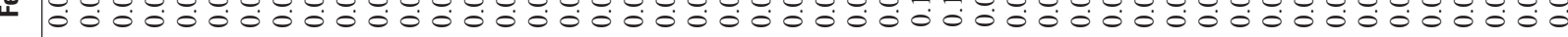

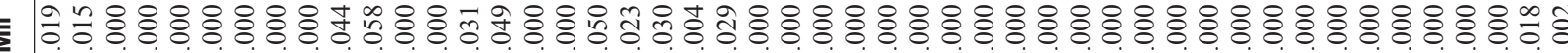
-00000000000000000000000000000000000000000000000

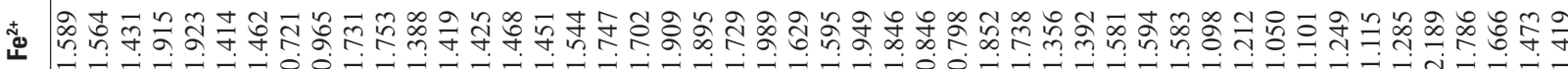

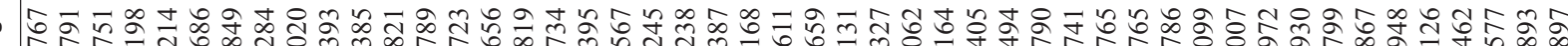
نंत

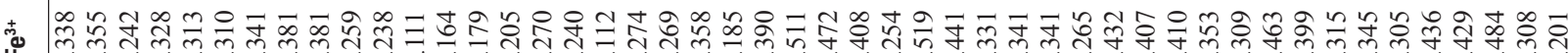

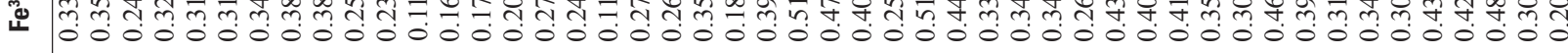

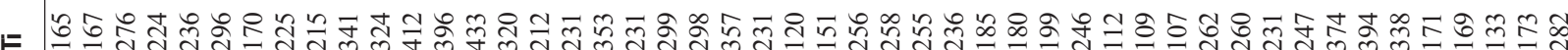

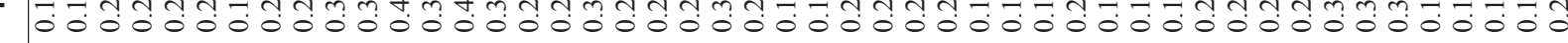

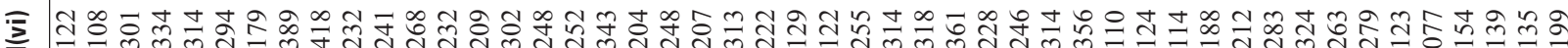

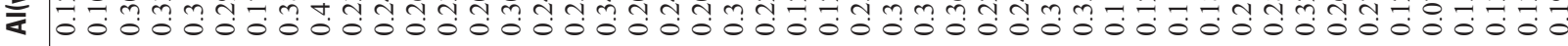

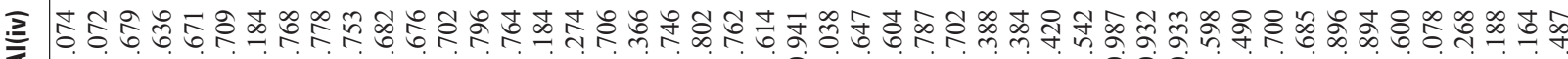

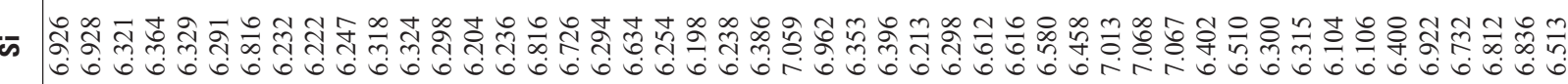

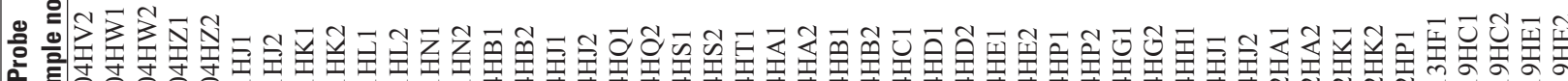
๙

$\cong \cong \cong$

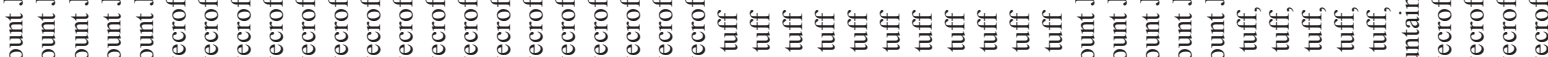

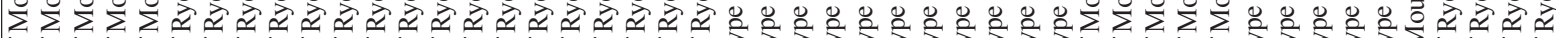

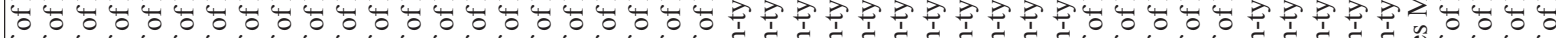

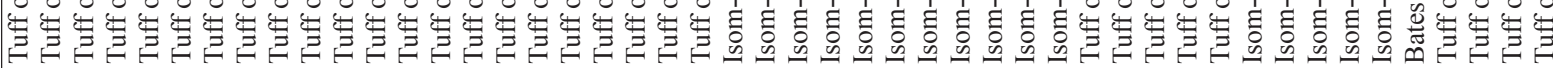




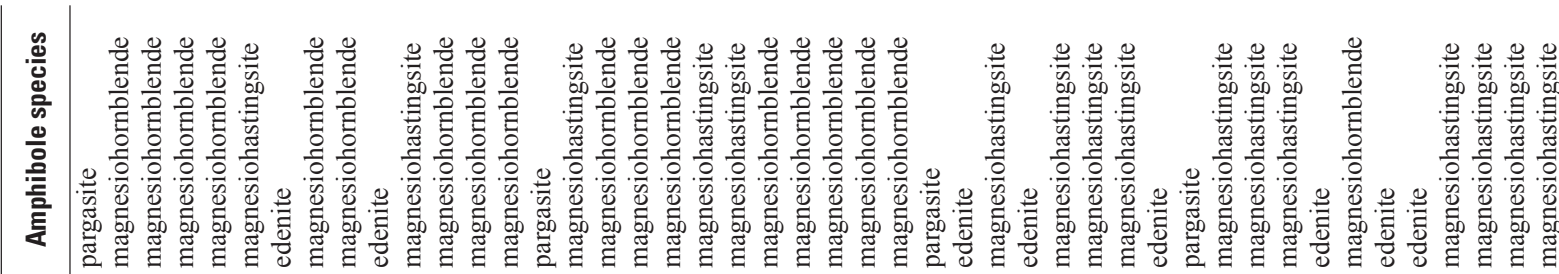

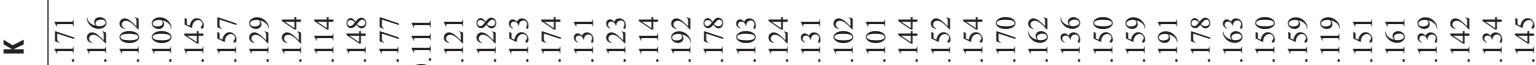
00000000000000000000000000000000000000000

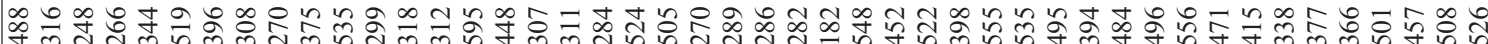

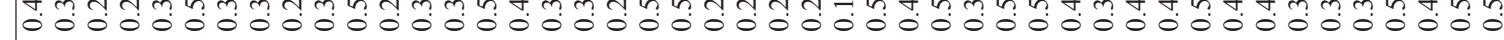

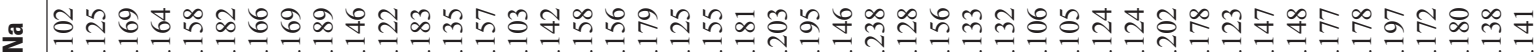
0000000000000000000000000000000000000000000000

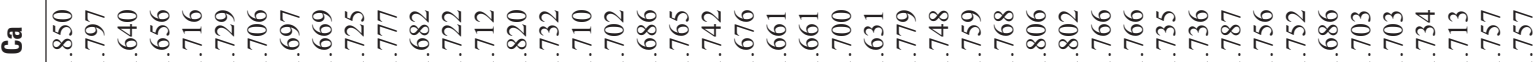

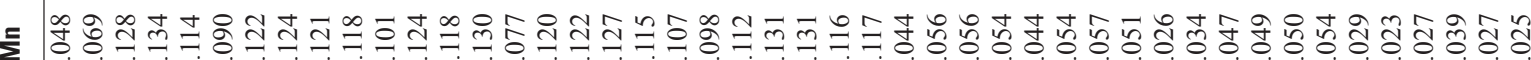
-000000000000000000000000000000000000000000000 声

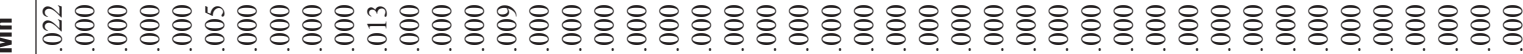
范

-

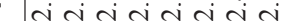

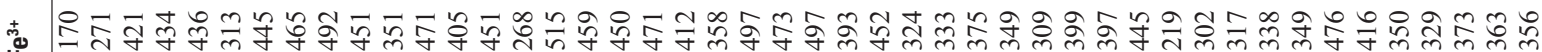

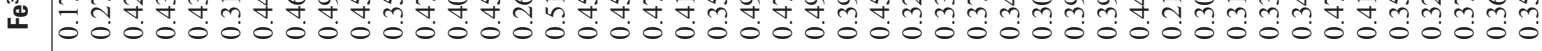

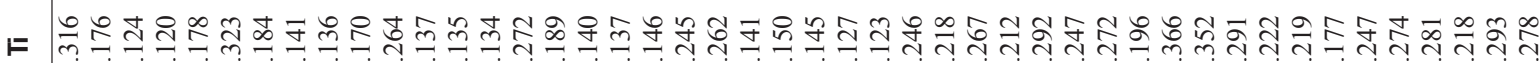
0000000000000000000000000000000000000000000000

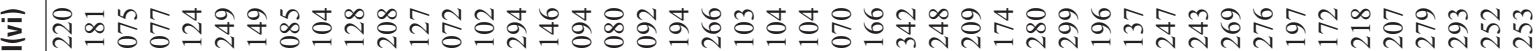
«

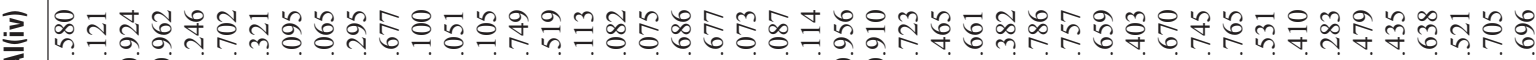

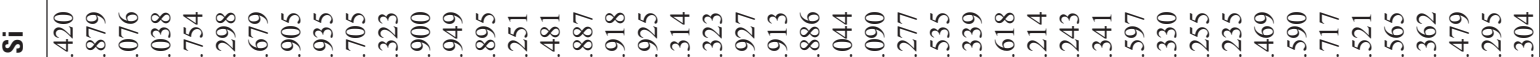

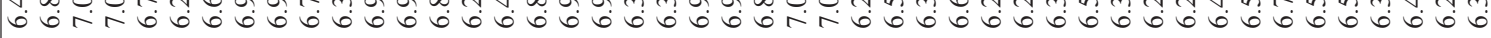

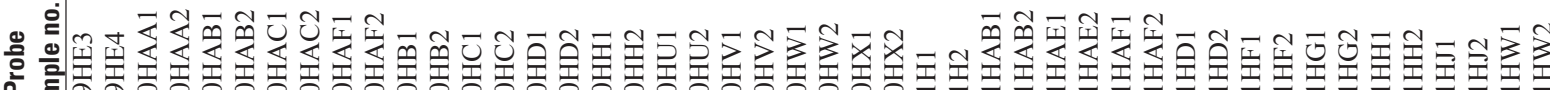
»

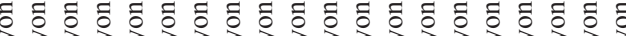

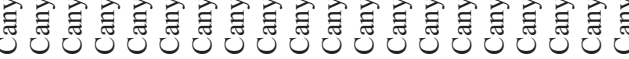

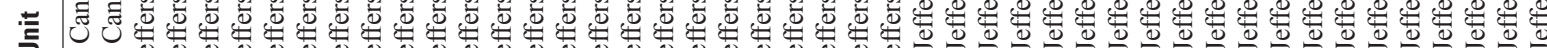

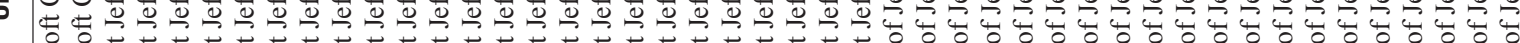

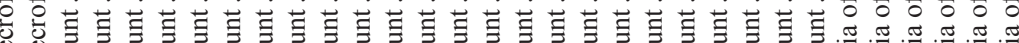

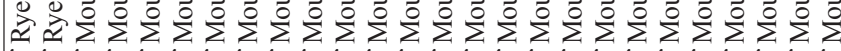

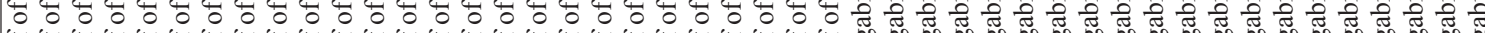

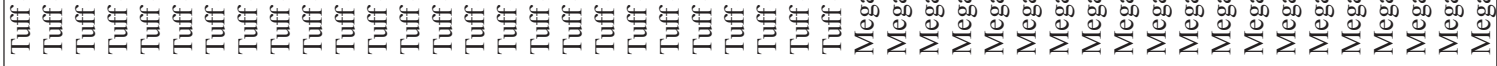

๘

言 高

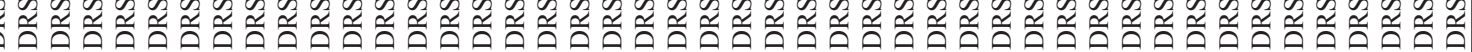




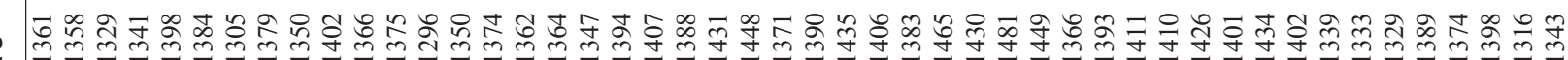

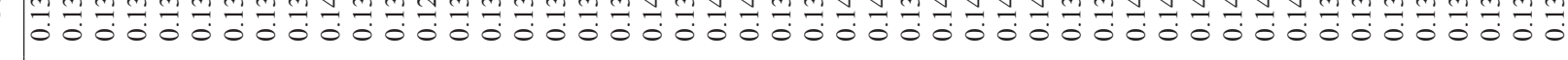

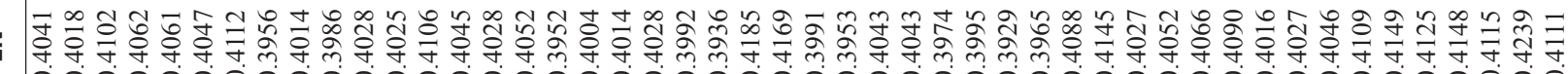

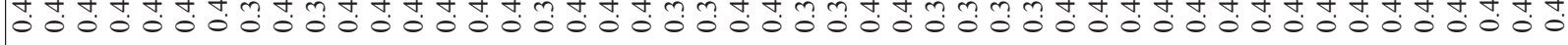

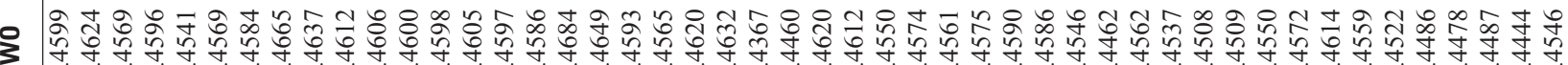

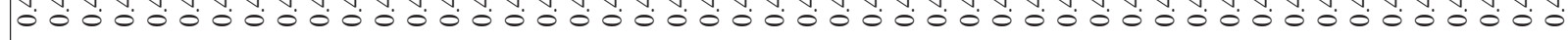

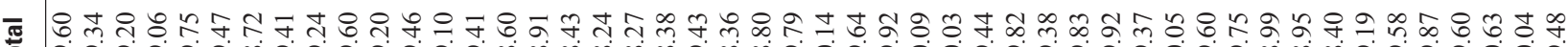

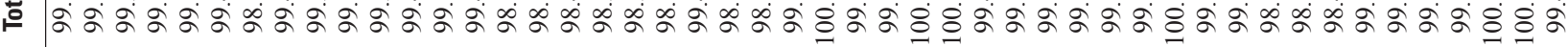

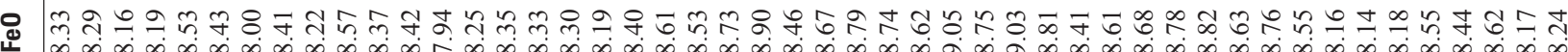

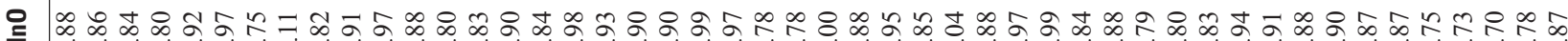

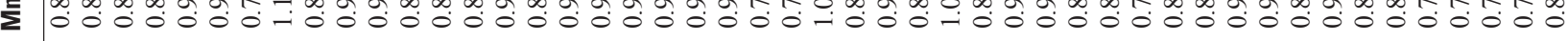

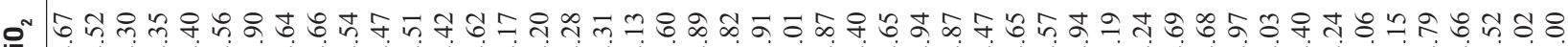
ถู่

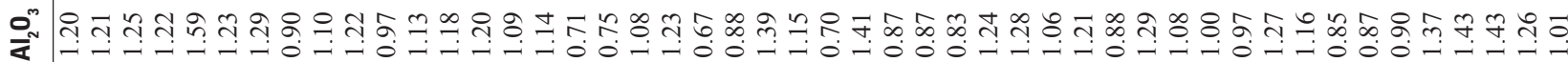

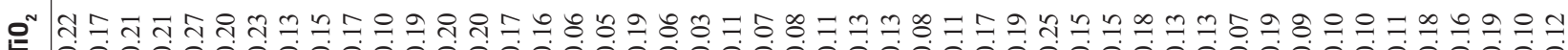

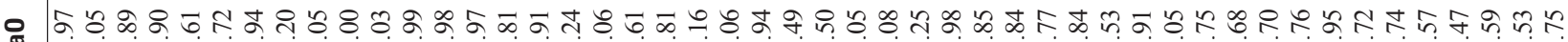

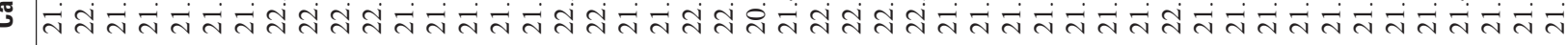

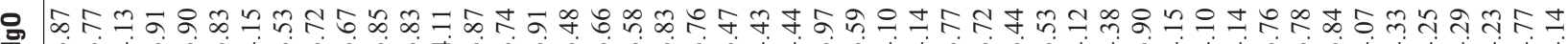

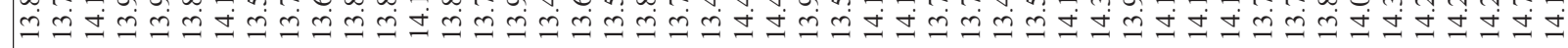

С

ч

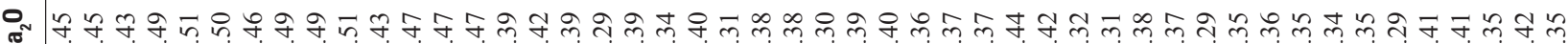

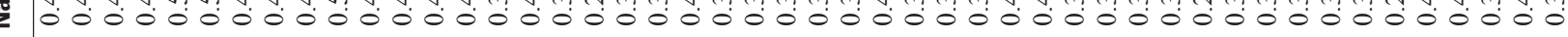

4

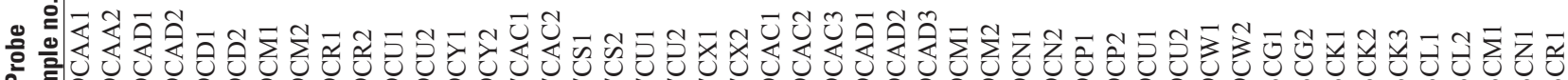

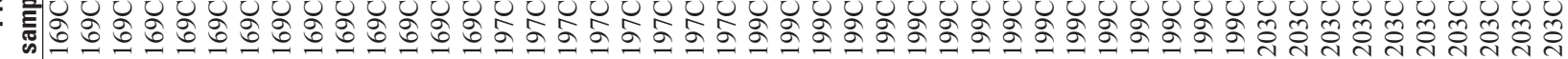

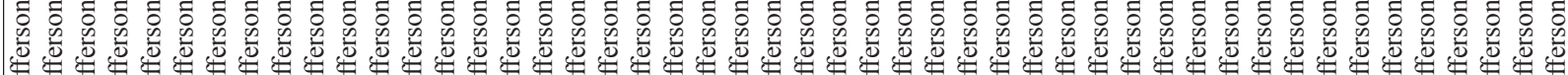

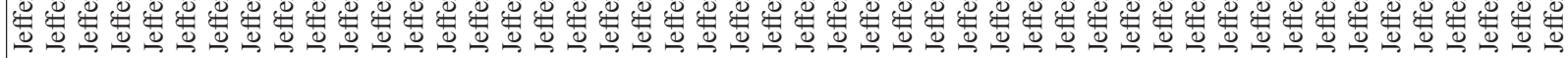

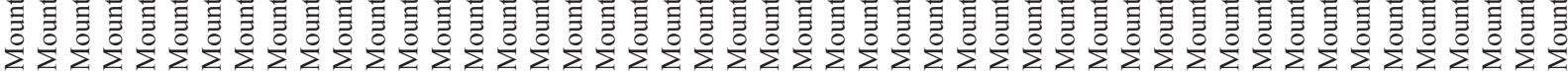

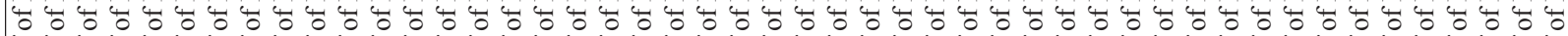

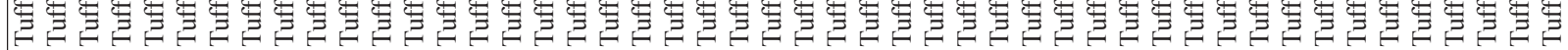

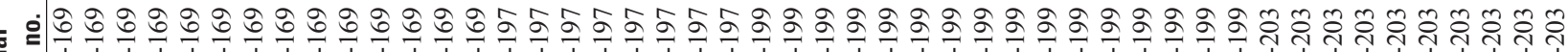

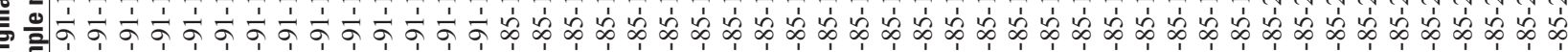




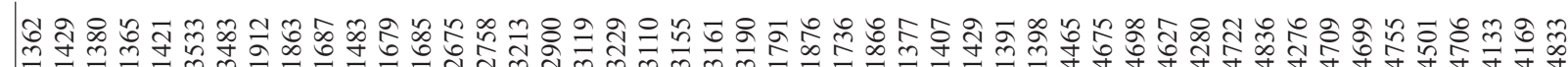

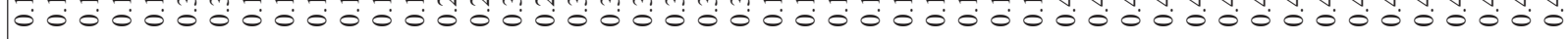

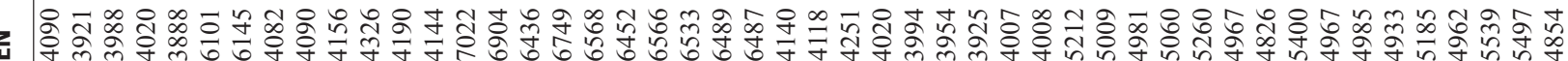

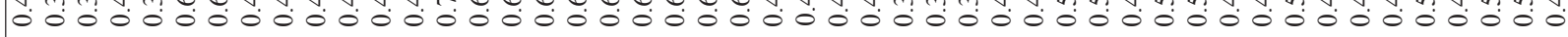

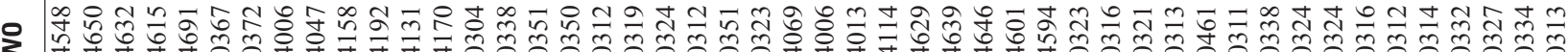

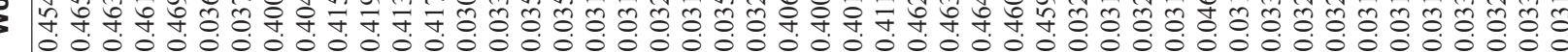

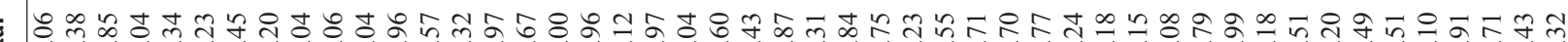

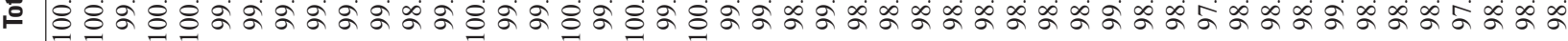

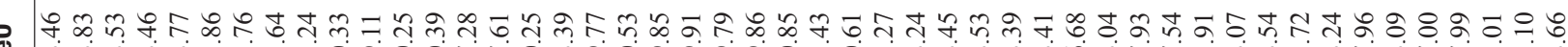

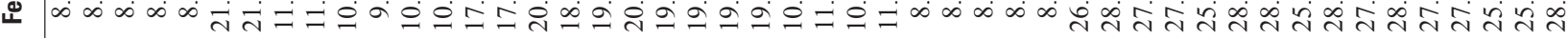

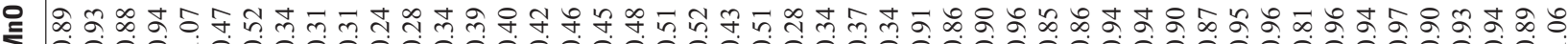
0 00 000000000000000000000000000000000000000000001

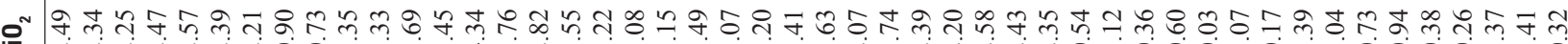

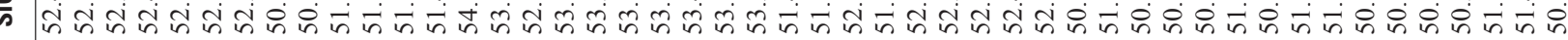
ơn

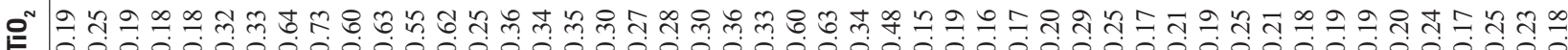

유워ำ ง

๙ิ

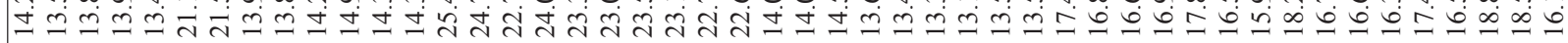

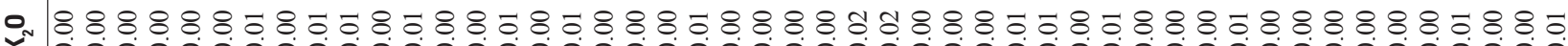

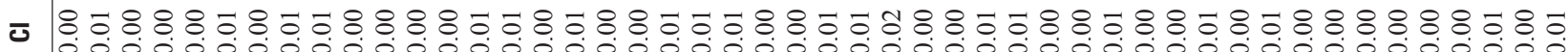

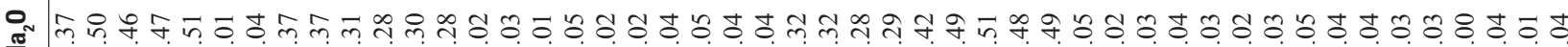

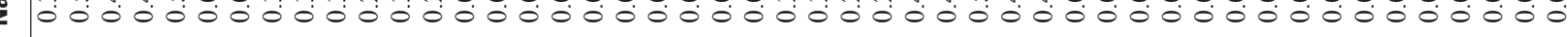

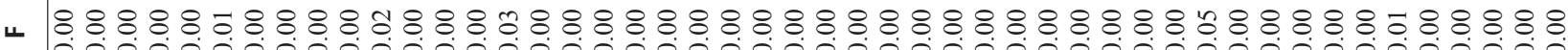

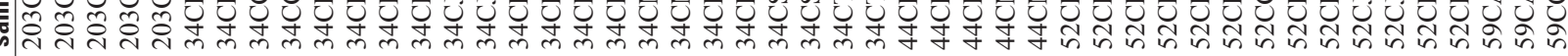

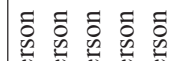

密离离离离

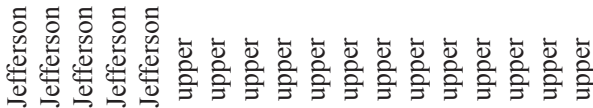

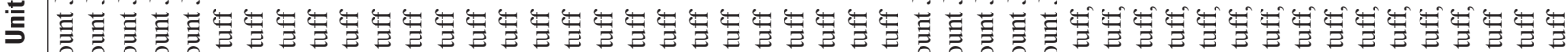

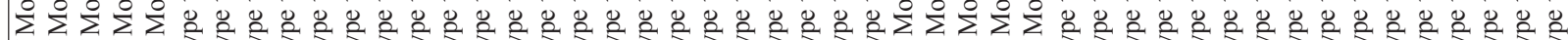

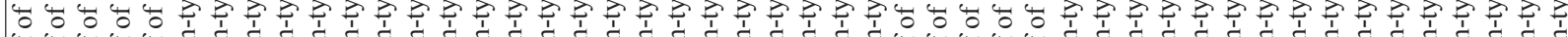

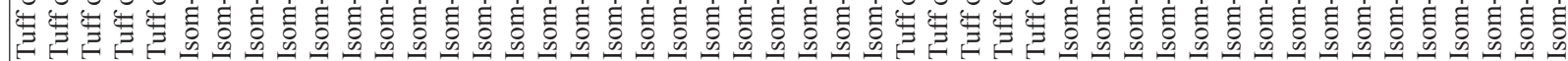

匹

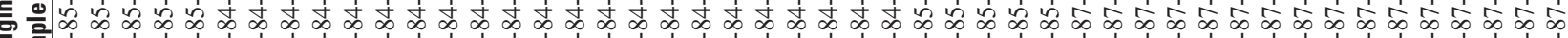

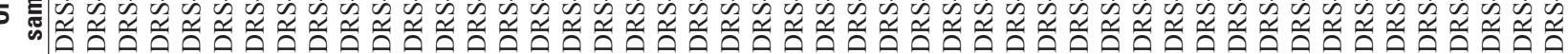




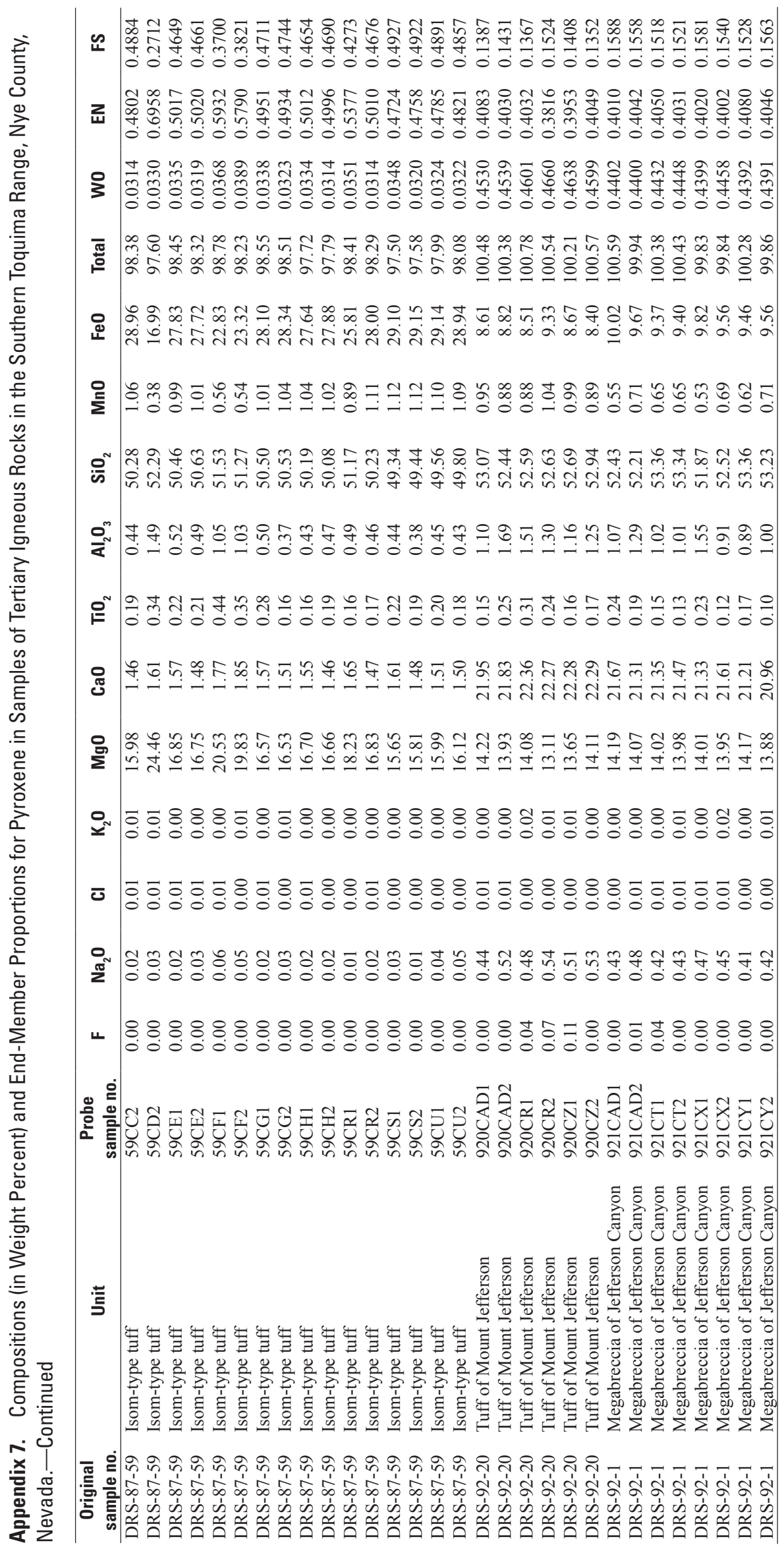





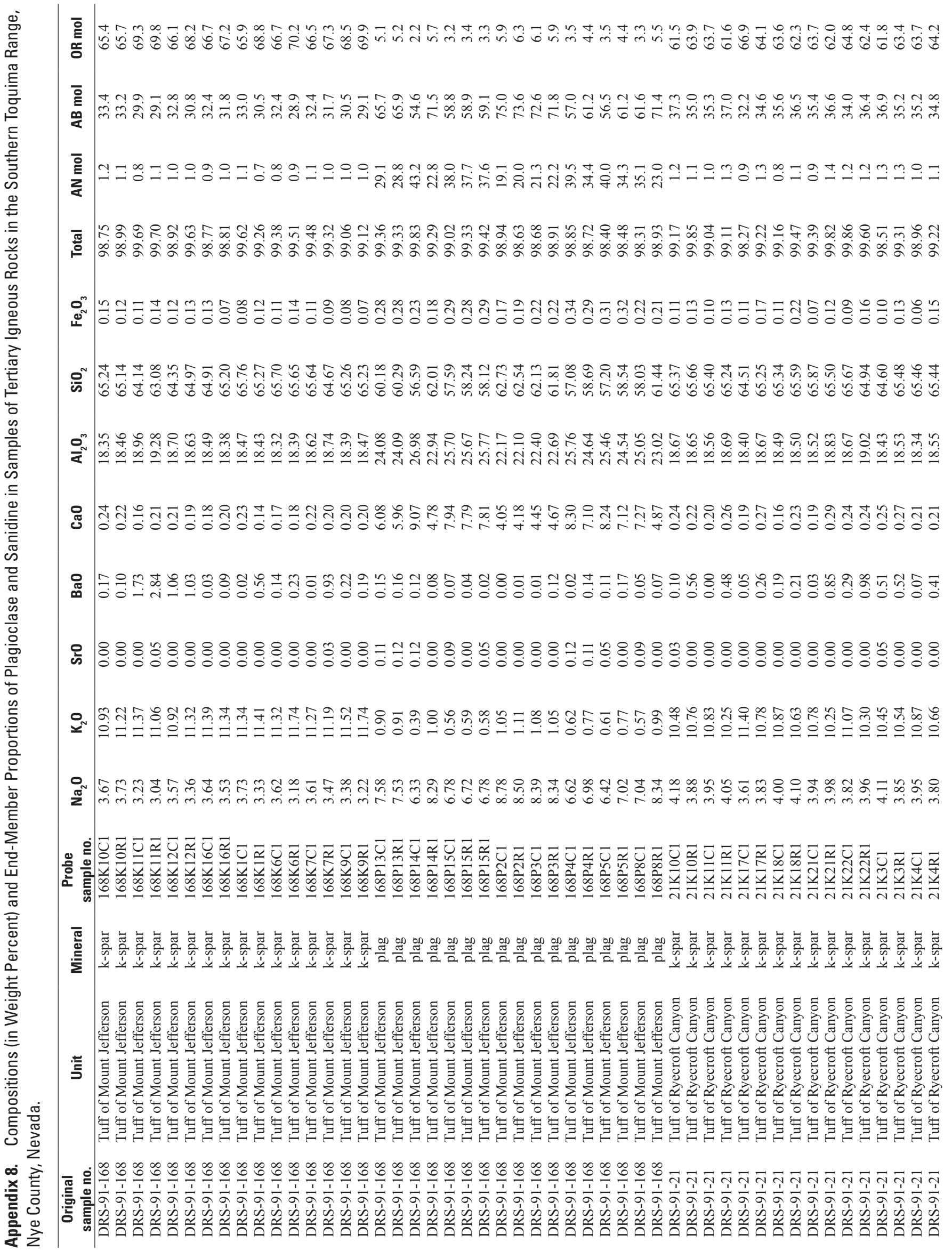




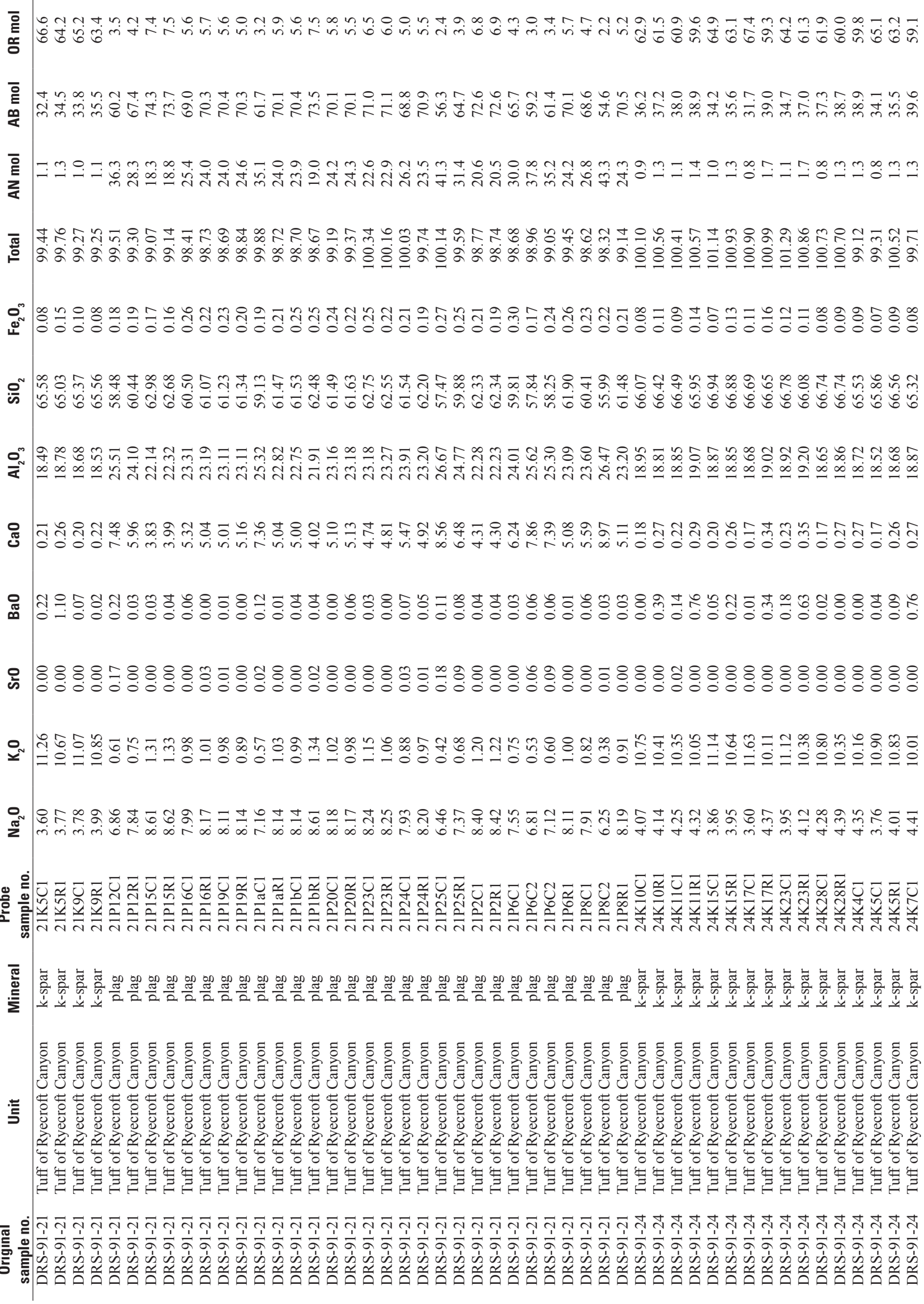




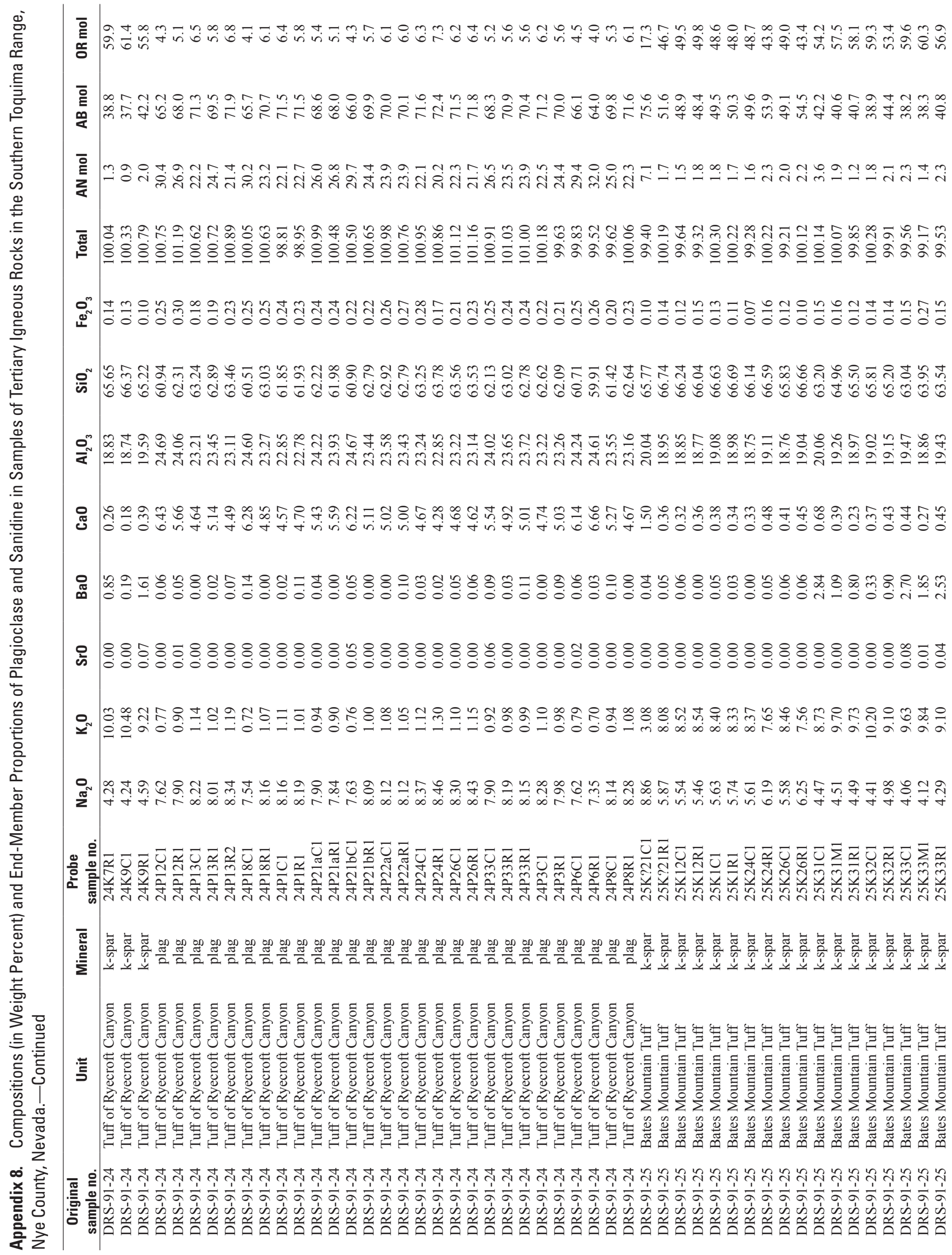




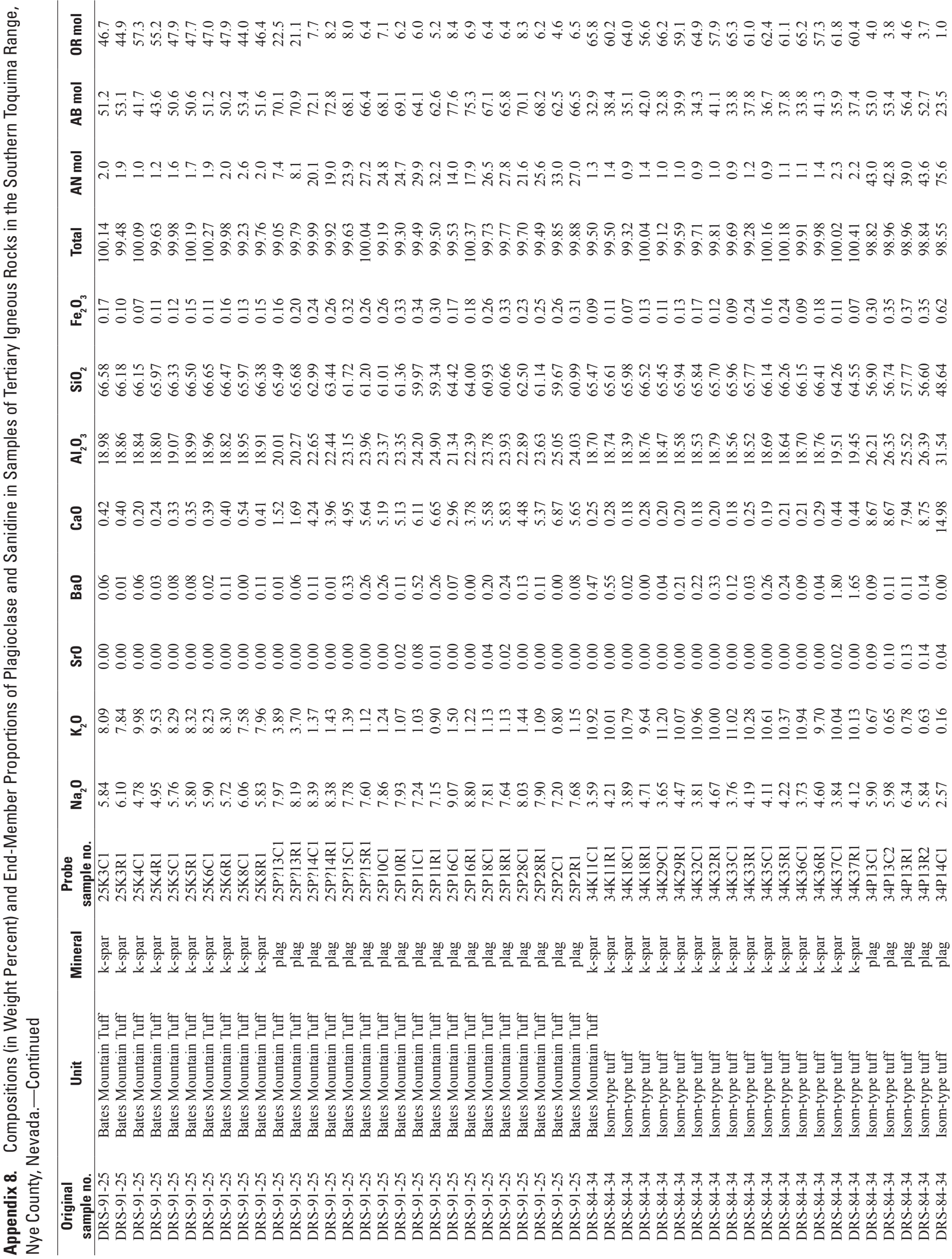




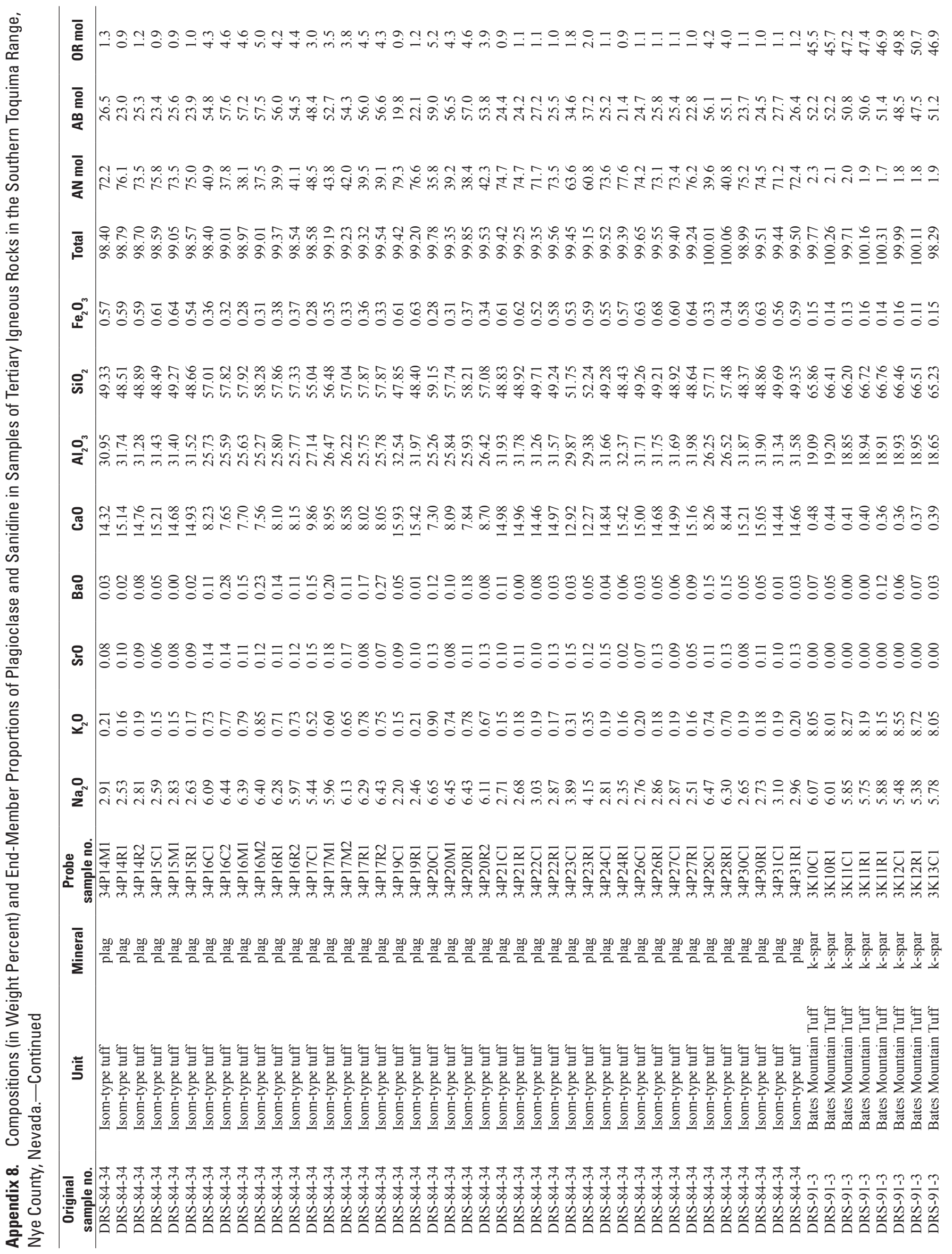




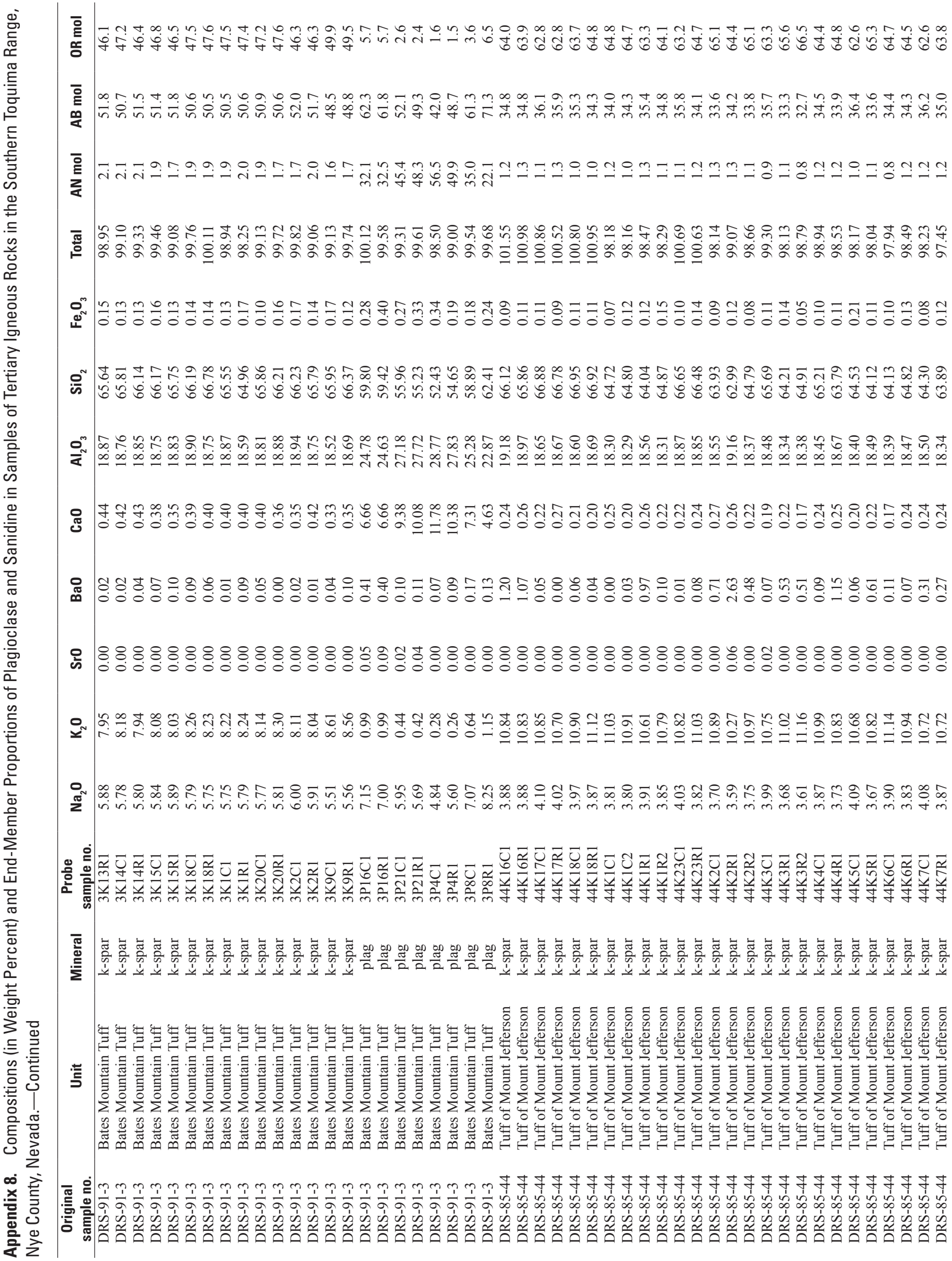




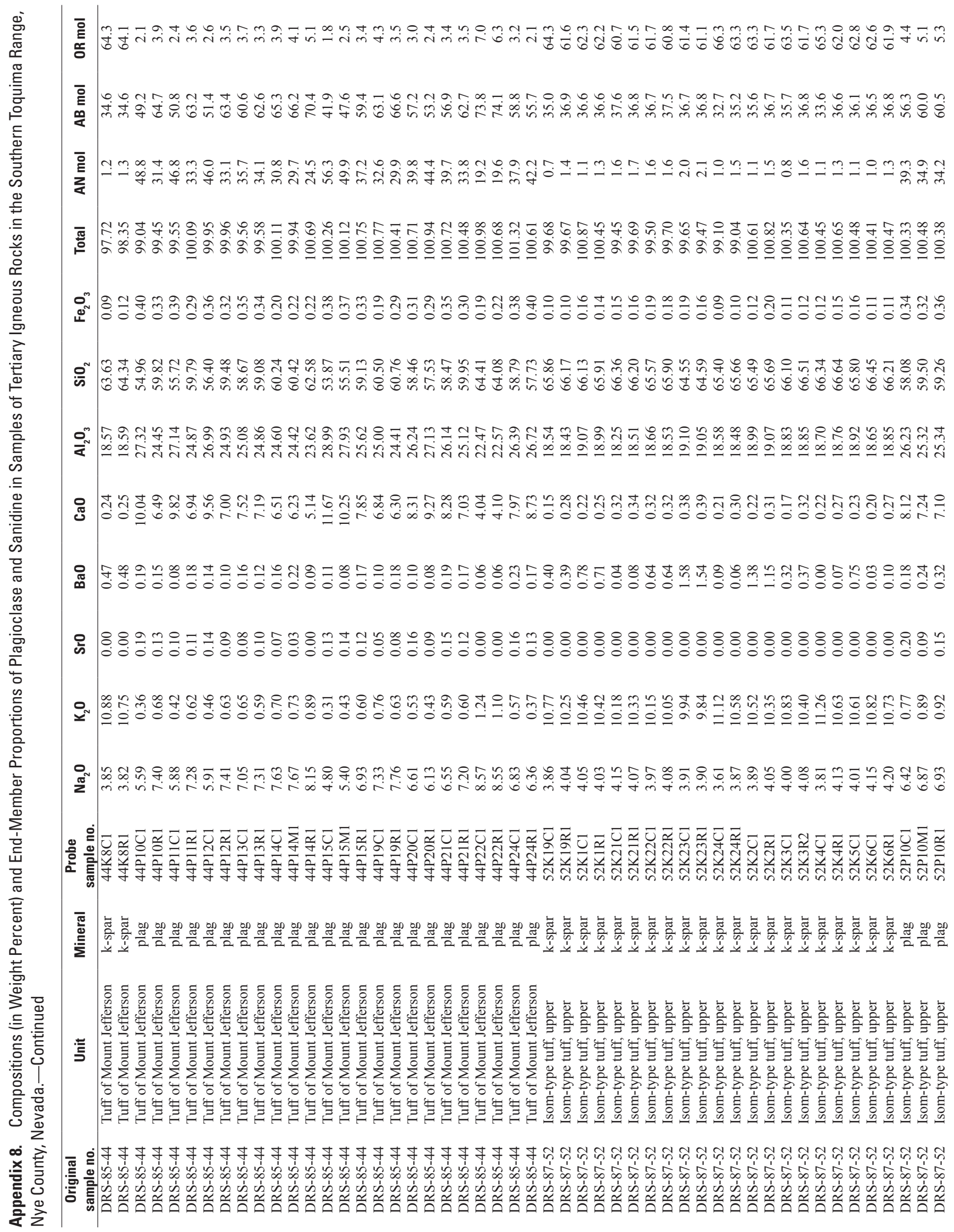


Tertiary Volcanic and Intrusive Rocks in Part of the Southern Toquima Range, Nye County, Nevada

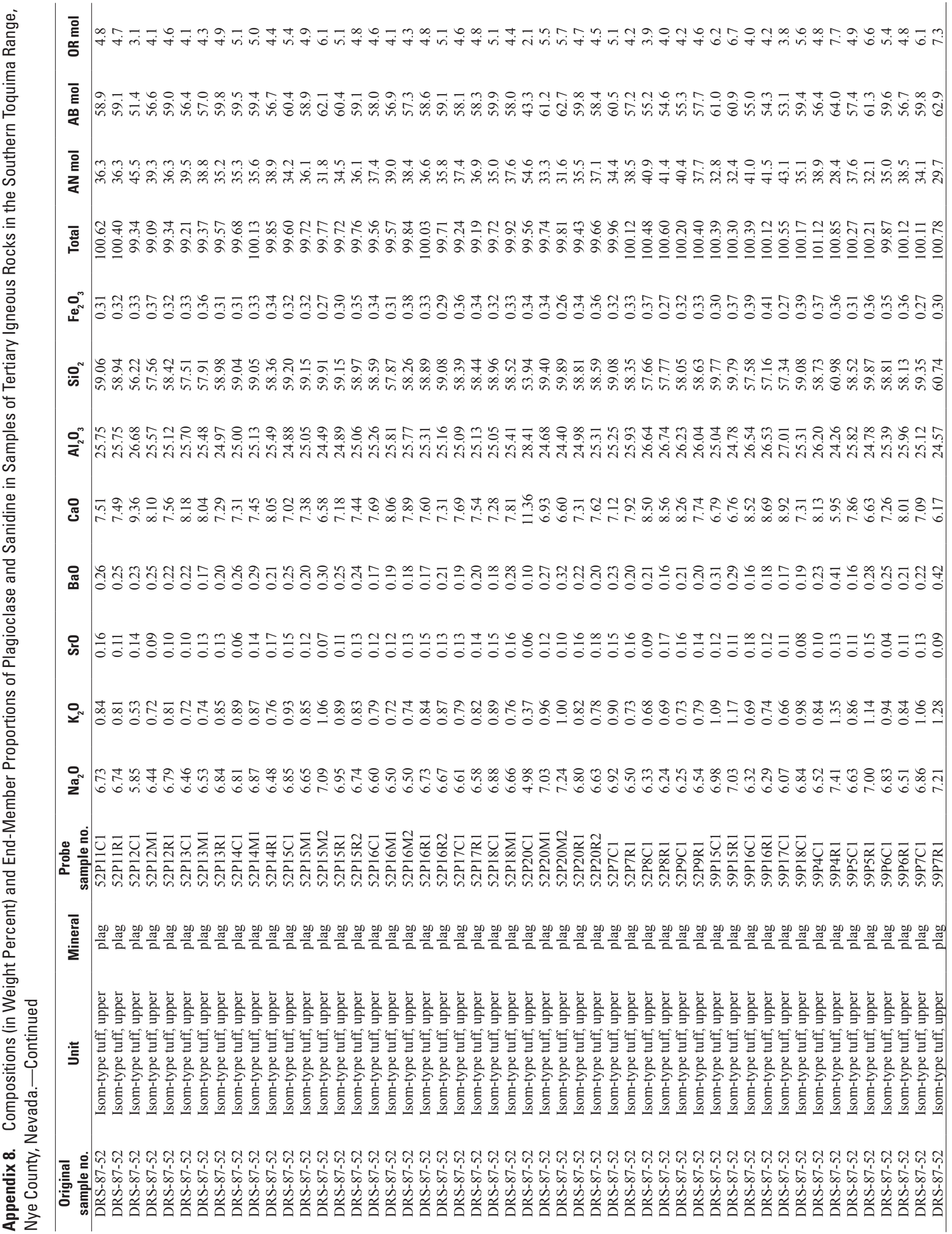


Publishing support provided by:

Denver Publishing Service Center, Denver, Colorado

For more information concerning this publication, contact:

Center Director, USGS Central Mineral and Environmental Resources Science Center

Box 25046, Mail Stop 973

Denver, CO 80225

(303) 236-1562

Or visit the Central Mineral and Environmental Resources Science Center Web site at:

http://minerals.cr.usgs.gov/

This publication is available online at:

http://dx.doi.org/10.3133/sir20135206 



\section{$\frac{\mathbb{2}}{3}$}

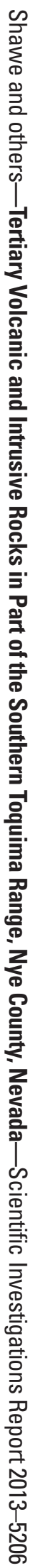

